\title{
Repair Weld Induced Residual Stresses in Trick-Walled Steel Pressure Vessels
}

\author{
G. C. Smith \\ P. P. Holz
}

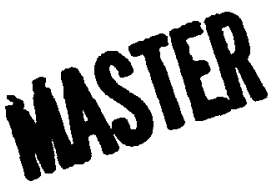

Prepared for the U S. Nuclear Regulatory Commission Office of Nuclear Regulatory Research Under Interagency Agreements DOE 40-551-75 and 40-552-75 
NUREC/CR-0093

ORU/RUREG/TI-153

Dist. Category 25

Coatract No. U-7405-eng-26

Engineering Technology Division

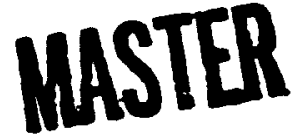

REPAIR WELD IMDUCED RESIDUAL STRESSES IM

THICK-WALLED STER PRESSURE VESSELS

G. C. Sinith

P. P. Holz

Manuscript Completed - Apri1 28, 1978

Date Published - June 1978

Prepared for the

U.S. Muclear Regulatory Comalsetion

Office of Muclear Regulatory Reaench

Dader Interagency Agrecimente DOL 40-551-75 and 40-552-75

WRC FII No. BO119

-

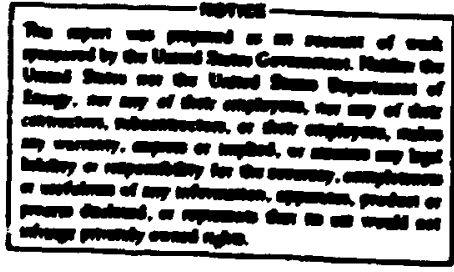

Prepared by

OAK RIDGE MTIOLAL LABORATOST

Oak R1dge, Temnessee 37830 operated by

union cheside conponation

for the

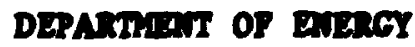


FOREIORD

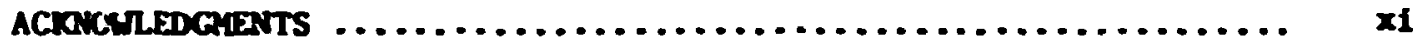

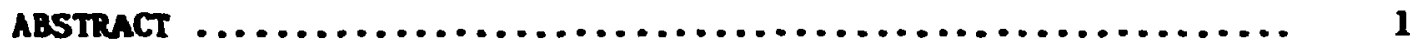

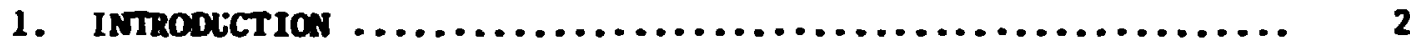

Reference...$\ldots \ldots \ldots \ldots \ldots \ldots \ldots \ldots \ldots \ldots \ldots \ldots \ldots \ldots \ldots \ldots \ldots$

2. DESCRIPTIOA OF VESSELS AND PROLGNGATIONS ............... 5

References ..................................... 12

3. DESCRIPTION OF REPAIR WELDS $\ldots \ldots \ldots \ldots \ldots \ldots \ldots \ldots \ldots \ldots \ldots \ldots$

$v-7 A$ and $v$-iA Simulation Repair Helds ................ 13

$V-7 B$ and $V-7 B$ Simulation Repair Welds ................. 19

$v-8$ and $V-8$ Simulation Repair Helds ................. 21

References ..................................... 28

4. RESIDUAL STRESS MEASUREMENT METHODS ................... 29

Direct Strain Gage Method .......................... 29

Hole-irfll1ng Method ............................... 30

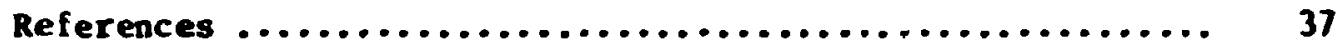

5. STRESS RELAXATION RESULTIMC FROH SECTIONINC ............ 39

V-8 Simulation Repair Weld Sectioning Correction ......... 40

v-7A Sinulation Repair Weld Sectioning Correction ........ 45

Surface Preparation .............................. 51

Reference $. \ldots \ldots \ldots \ldots \ldots \ldots \ldots \ldots \ldots \ldots \ldots \ldots \ldots \ldots \ldots \ldots . \ldots \ldots \ldots$

6. SUMYARY OF EXPERIMEUTAL RESULTS .................... 52

Axial and Circunferential Residual Stresses on the Surface of the $V-7 B$ Vessel $\ldots \ldots \ldots \ldots \ldots \ldots \ldots \ldots \ldots \ldots \ldots \ldots \ldots$

Circumferential Residual Stresses Through the Thickness of the V-7A Simulation Repair Weld ...................

Axial Residual Stresses Through the Thickness of the V-7A Simulation Repair Weld ............................

Axial and Circumferential Residual Stresses on the Surface

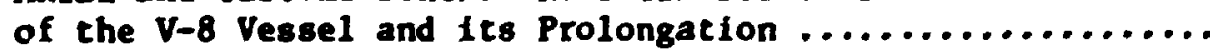

Circumferential Residual Stresses Through the Thickness of

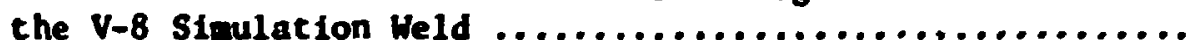

References $\ldots \ldots \ldots \ldots \ldots \ldots \ldots \ldots \ldots \ldots \ldots \ldots \ldots \ldots \ldots \ldots \ldots \ldots \ldots$

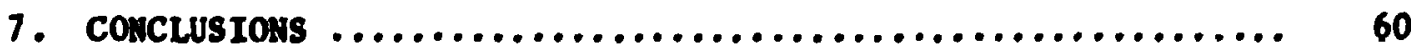




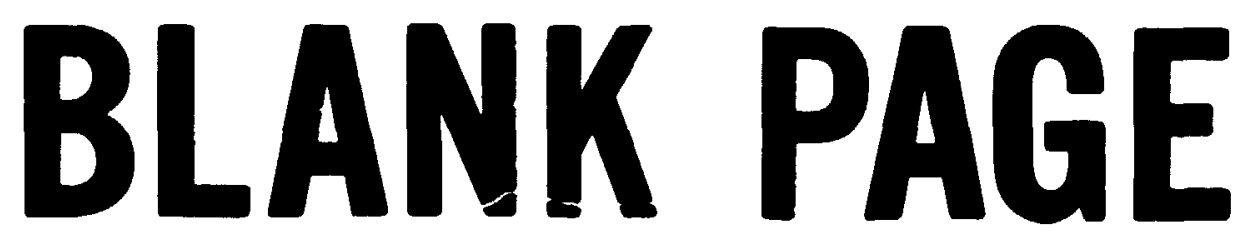


Page

APPENDIX A. HELDINC PROCEDURE SPECIFICATICY ................ 63

APPENDIX B. HOLE-DKILLING MEASUREAENTS MADE ON STRESS-FREE

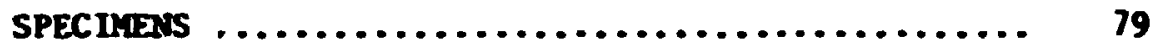

APPENDIX C. V-7 SERIES REPAIR WELDS - MELDABLE STRAIN GACE meAsUrgatzarts ............................. 85

APPENDIX D. V-8 SERIES REPAIR WELDS - WELDABLE STRAIN GAGE MEASURETERTS .............................. 93

APPENDIX E. V-7 SERIES REPAIR WELDS - HOLE-DRILLIIN

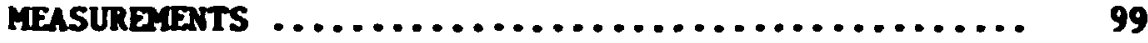

APPENDIX F. V-8 SGRIES REPAIR MELDS - HOLE-DRILLIAV MEASURELERTS .......................... 117

APPENÕ̃X G. DISCUSSION OF THE HOLE-DRILLING TYPE SURFACE RESIDUAL STRESS MEASITEDIJITS TAKEA FPOH THE V-8 VESSEL 


\section{FOREUOR:}

The work reported here was performed nostly at Oak Ridge lational Laboratory (OBh) under sponsorship of the U.S. Nuclear Regulatory Comnis. 'on's (NRC) Heavy-Section Steel Technology (HSST) Progran, which is directed by ORNL. The progran is conducted as part of the ORR Pressure Vessel Technology Progran, of which G. D. Whitan is manager. The manager for the NRC is E. K. Lynn.

This report is designated Heavy-Section Steel Technology Progra Technical Report No. 48. Prior reports in this series are listed below.

1. S. Yukawa, Evalwation of Periodic Proof Testing and Marm Prestressing Procedures for thuclear Reactor Vesse Ls, HSSTP-TR-1, General Electric. Company, Schenectady, N.Y. (July 1, 1969).

2. L. W. Loechel, The Effect of Section Size on the Tranoition Temperature in Steel, MCR-69-189, Martin Marietta Corporation, Denver, Colo. (Hov. 20, 1969).

3. P. N. Randall, Gross Strain Measure of Fracture Toughness of Steels, HSSTP-TR-3, IRH Systens Group, Redondo ieach, Callf. (Nov. 1, 1969).

4. C. Visser, S. E. Gabrielse, and W. VanBurea, A Twu-Dimensional ELastic-Plastic Aralysis of Practure Test Specimens, WCAP-7368, Hestinghouse Electric Corporation, PUR Systens Division, Pitesburgh, Pa. (October 196s).

5. T. R. Mager, F. O. Thomas, and W. S. Hazelcon, Evaluation by Linear Elastic Fracture Mechanics of Radiation Danage to Pressure Vessel Steel8, HCAP-7328 (Rev.), Hestinghouse Electric Corporation, PWR Systeas Division, Pitcsburgh, Pa. (October 1969).

6. H. O. Shabbits, H. H. Pryle, and E. T. Weasel, Heavy Section Fracture Toughness Properties of A533 Grade B Class 1 Steel Plate and Submerged ArC Weldnent, WCAP-7414, Hestinghouse Electric Corporation, PIR Systeas Division, Pittsburgh, Pa. (Decenber 1969).

7. F. J. Loss, Dynoric Tear Test Investigations of the Fracture Toughness of Thick-Swction Steel, NRL-7056, U.S. Navai Research Laboratory, Washington, D.C. (May 14, 1970).

8. P. B. Crosley and E. J. Ripling, Crack Arrest Fracture Toughress of A533 Grade B Class 1 Pressure Vessel Steel, HSSTP-TR-8, Materials Research Leboratory, Inc., Glemwod, Ill. (March 1970).

9. T. R. Mager, Post-Imadiation Testing of 2 T Compaot Tenoion Speotmens, WAP-7561, Westinghouse Electric Corporaclon, PUR Syotens Division, Pitesburgh, Pa. (Auguet 1970). 
10. T. R. Mager, Fracture Toughness Characterization Stucig of $\therefore$ izz, Jmde B, Class 1 Steel, UCAP-7578, Westinghouse Electric Corporation, PUR Systens Division, Pittsburgh, Pa. (October 1970).

11. T. R. Mager, irotch Preparation in Compact Tension Specinens, HCAP7519, Hestinghouse Electric Corporation, PWR Systems Division, Pitcsburgn, Pa. (Noveaber 1970).

12. N. Levy and P. V. Marcal, Three-Dinensional Elastic-PLastic Stress and Strain Analysis for Fractive lechanics, Phase I: Simple Flaved Specimens, HSSTP-TR-12, Brown University, Providence, R.I. (Decewber 1970).

13. H. 0. Shabbits, Dynaric Fracture Toughness Properties of Heavy Section A533 Grade B, Class i Steel Plate, HCAP-7623, Westinghouse Electric Corporation. PUR Systens Division, Pittsburgh, Pa. (Decesber 1970).

14. P. N. Randall, Tross Strain Crack Tclerance of A 533-3 Steel, HSSTPTR-14, TRU Systems Group, Redondo Beach, Calif. (May 1, 1971).

15. H. I. Corten and R. H. Sailors, ReLationship Between Material Fracture Toughness Using Fracture Hechanics ard Transition Temperature Tests, T\&AM Report 3:46, University of Illinois, Urbana, I11. (Aug. 1,1971 ).

16. T. R. Mager and V.J. McLoughlin. The Effect of an Environuent of High Temperature Primary Grade Muclear Reactor Water on the Fitione Crack Growth Characteristice of A533 Grade B OLass 1 Plate and Weldment Haterial, WCAP-7776, Hest inghouse Filectric Corporat Ion, PWR Systens Division, Pittsburgh, Pa. (October 1971).

17. N. Levy and P. V. Marcal, Three-Limensional Elastic-Plastic Stress and Strain Aralysis for Fracture Mechanics, Phase II: Improved Modeling, HSSTP-TR-17, Brown University, Providence, R.I. (November 1971).

18. S. C. Grigory, Six-Inch-Thick Plawed Tensile Tests, Pirst Trchisal Sumbary Report, Longitudinal Specinens 1 through 7, HSSTP-TR-18, Southwest Research Institute, San Antonio, Tex. (June 1972).

19. P. H. Randall, Effects of Strain Gradients on the Gross Strain Crack Tolerance of A 533-B Steel, HSSTP-TR-19, TRH Systens Group, Redondo Beach, Callf. (May 1, 1972).

20. S. C. Grigory, Tests of Six-Inch-Thick Flawed Tensiie Specinene, Second Technical Summary Report, Transvarse Spesimens nombers 8 through 10, Welded Specimens himbere 11 through 13, HSSTP-TR-20, Southwest Research Institute, San Antonio, Tex. (June 1972).

21. L. A. James and J. A. Hilliane, Heavy Section Steel Technology Program Techrical Report No. 21, The Effect of Temperature and Neutron Irradiation Upon the Patigue-Crack Propagation Behavior of ASTM A533, Grade B, Clase 1 Steel, HEDL-TME-72-132, Hanford Engineering Development Leboratory, Richland, Wash. (September 1972). 


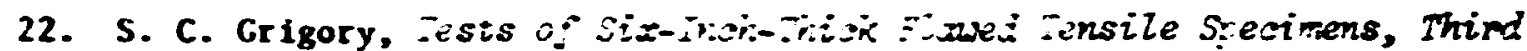

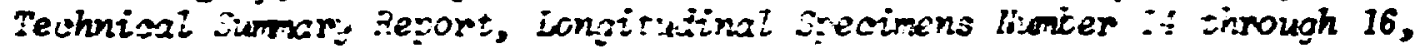
inflawed Speoiren fimber 1?, HSSTP-TR-22, Southwest Research Inst1tute, San Antonio, Tex. (October 1972).

23. S. C. Grigory, Fests : Six-Inch-Thici Eluwed Tensile Specinens, Fourth Techical Simmir: Report, Fests of One-Inch-ritick Flaned Tensile Stecimens for Size jefect Evaluation, HSSTP-TR-23, Southrest Research Institute, San Antonio, Tex. (June 1973).

24. S. P. Ying and S. C. Grigory, Tests of Six-Inch-Thick Tensile Specimens, Fifth iechnical Sumary Report, Acoustic Emission :tonitoring of One-Inch and Six-Inch-Thick Tenoile Specimens, HSSTP-TR-24, Southwest Research Institute, San Antonio, Tex. (Novenber 1972).

25. R. W. Derby et al., Test of 6-Inch-Thick Pressure Vessels. Series 1: Intermedia:-: Test Vessels $V-i$ and $i-2$, ORN-4895 (February 1974).

26. W. 1. Stelzman and R. G. Berggren, Radiation Strengthening and Bnbrittlement in Heavy Section Piates ond Welds, ORNL-4871 (June 1973).

27. P. B. Crosley and E. J. Ripling, Crack Arrest in an Increasing $K-$ Field, HSSTP-TR-27, Materials Research Laboratory, Glemwood, I11. (January 1973).

28. P. V. Marcal, P. M. Stuart, and R. S. Betces, Elastic-PLastic Behavior of a Longitudinal Semi-ELIiptical Crack in a Thick Pressure Vessel, Bzom Universicy, Providence, R.I. (June 1973).

29. K. J. Stelzann, Characterizacion of HSST Places 01, 02, and 03 (1n preparation).

30. D. A. Canonico, Characterizacion of Heavy Section Weldnents in Pressure Vessel Steels (in preparation).

31. J. A. Willians, The Irradiation and Temperature Dependence of Tensiie and Fracture Properties of ASTM A533, Grade B, Class 1 Steel Plate and Wehtment, HEDL-THE 73-75, Hanford Engineer ing Developinent Laboratory, Richland, Wash. (August 1973).

32. J. M. Stelchen and J. A. Williams, High Strain Rate Fensile Properties of Irradiated ASTM A533 Grade B Class 1 Pressure Vessel Steel. HEDLThE 73-74, Hanford Engineering Development Laboratory, Richland, Wash. (July 1973).

33. P. C. Riccardella and J. L. Swedlow, 4 Combined Analytical-Experimental Fracturs Study, WCaP-8224, Westinghouse Electric Corporation, PUR Systens Division, Pittsburgh, Pa. (October 1973).

34. R. J. Podlasek and R. J. Eiber, Final Report on Investigation of Mode III Crack Extension in Reactnr Piping, Batcelle Columbus Laborator les, Columbus, Ohto (May 1974). 
35. T. R. Mager et al., Interin Keport on the Effect of Low Frequencies on the Fatigue Crack Growth Characteristics of A533 Grade B CLass 1 Plate in an Environment of High-Temperature Primany Grade thuclear Reactor idater, WCAP-8256, Hestinghouse Electric Corporation, Pittsburgh, Pa. (Deceaber 1973).

36. J. A. HIll1ans, The Irradiated Fracture Toughress of ASTH A533, Jrade B, Class 1 Steel Measmed with a Fowr Inch Thick Compact Tenoion Speciman, HEDL-TIE 75-10, Hanford Englneer Ing Developent Laboratory, Richland, Wash. (January 1975).

37. R. A. Bryan et al., Test of 6-in.-thick Pressure iessels, Series 2: Intermediate Test Vessels V-3,V-4, and V-6, Oanl-5059 (Woveaber 1975).

38. T. R. Mager, S. E. Yanichko, and L. R. Singer, Fractwere Toughress Characterization of HSST Intsmediate Pressure ressel Naterial, LCAP8456, Westinghouse Electric Corporation, PItcsburgh, Pa. (Deceber 1974).

39. J. G. Herkle, G. D. Whitan, and R. H. Bryan, An svaluation of the USST Progrow Intermediate Pressure Vessel Testo in Terms of LightWater Reactor Pressure Vessel Safety, OndL/nt-S090 (Novedber 1975).

40. J. G. Merkle et al., Test of 6-in.-thick Pressure Vessels. Series 3: Intermediate Test Vessel V-7, ORNL/NUREG-1 (August 1976).

41. J. A. Davidson et al., The Imradiated Dynavic Eracture Toughness of ASTM A533, Grade B, Class 1 Steel Plate and Submerged-Are Weldnent, UCAP-8775, Westinghouse Electric Corp., Pittsburgh, Pa. (October 1976).

42. R. D. Cheverton, Pressure Vessel Fracture Studies Pertaining to a PUR LOCA-ECC Thermat Shock: Experiments TSE-1 and TSE-2, Onul NUREG/TH-3 (Septenber 1976).

43. J. G. Herkle er ai., Test of 6-Inch-Thiok Pressure Vessels. Series 4: Intermediate Test Vessels V-5 and V-9 with Inside Moszle Comer Cracks, ORTL/NUREG-7 (August 1977).

44. John A. Hillians, The Ducitle Practure Toughress of Heavy Section Steel Plate, Hanford EngIneer Ing Developant Laboratory, RIchland, Uash. (In preparation).

45. R. H. Bryan et al., Test of 6-in.-thick Presenve Veseelo, Series 3: Intermediate Test Veseel V-1A Under Sustained Loading, ORUL/NUREG-9 (In preparacion).

46. R. D. Cheverton and S. E. Bolt, Preseure Vesel Practure Studies Pertaining to a PUR LOCA-ECC Thermal Shook: Experimento TSE-3 and TSE-4, and Update of TSE-1 and TSB-2 Analysis, 0nn/NUREG-22 (in preparation). 


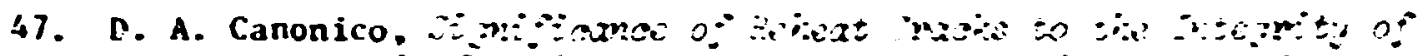

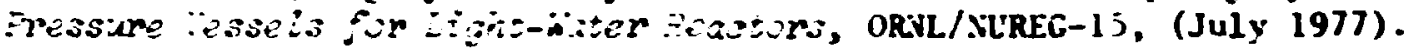

Copies of these reports may be obtained from Laboratory Records Department, Oak Ridge :ational Laboratory, P.0. Box X, Oak Ridge, Tenr. 37830. 


\section{ACRNOULEDCAIIITS}

The authors are indebted to a suber of people who ade contributions to this work. A. Bush, Westinghouse Research and Developeent Center, supervised the bulk of the hole-drilling measureneats on two sections machined fron the V-TA simulation repair weld. R. Saith of the Electric Fourer Research Insticute anaged his organization's participation in this effort. J. E. Saith, Okd, supervised the installation of the veldable gages that were attached to the $V-7$ and $V-8$ series of repair welds, and he, along with R. H. Bryan, Okn, provided any useful sugsestions and coments. The ORn measurenents discussed in this report were perforned by $R$. Snith, Jr., T. A. King, H. D. Curtis, and H. F. Jackson. He also ackoouledge the cooperative assistance by personnel of Combustion Engineering. Chattanooga, Tennessee, and lestinghouse, Tama, Florida, and by machine shop personnel in Union Carbide's Y-12 Plant Alpha One shop. Finally, the authors wish to thank J. G. Herkle who, in the course of reviewing the report, offered many helpful suggestions to improve the presentation of the material. 


\title{
REPAIR WELD IXDUCED RESIDUAL STRESSES IN THICK-WNLLD STEEL PRESSURE VESSELS
}

\author{
C. C. Saith \\ P. P. Holz
}

\begin{abstract}
If a flaw requiring corrective action were to be found in an operating nuclear pressure vessel, there would be considerable safety and ecosonic inplications. Should such a flaw be found, one possible corrective action would be an in situ repair weld. A repair of this type would presuably involve grinding away aterial in a region encompassing the flaw and then filling the resulting cavity with weld wetal. Thereal stress relfeving under those conditions could lead to serfous difficulties associated with thermal expansion and warpage and would therefore nost likely be avolded. Sucil a departure from noral procedure raises questions relating to residual stresses and eterial toughness levels which would baye ts be assezsed before a repair could be recomended or approviad. The risidual stress measurenents reported here are intended to provide baseline infornation to aid in an assessment should such a repair ever have to be seriously considered.

Restdual stress measurements were made on six large repair welds in two experimental steel pressure vessels and in two lindrical vessel prolongations made from A533, gT «de B, class 1 steel with nominal wall thicknesses of $152 \mathrm{~m}(6.0 \mathrm{in.})$. The repair welds were perforned in accordance with Se.:tion XI of the Anerican Society of Hechanical Engineers Boiler and Pressure Vessel Code. The repair procedure enployed, known as ti:L bial:bead techaique, was devised for repair welds that for practical considerations could not undergo routine high-temperat:it' thermal postweld stress relief. In theory the half - or cemper-bead technique is structured so that each weld pass is applited in a manner which results in teapering the preceding w.old pass. Tize residual stresses were deternined from pre- and postwela strain gage measurements and from measurements using a semidestruclive procedure known as the hole-drilling method. The two cylindrical prolongation specibens were sectioned in order to expose radial planes through each weld. Through-thickness residual siressen based on hole-drilling type measurewents, including a correstion for sectioning, are reported. It was found that, in general, high tensile residual stresses on the order of the yield stress existed in the base metal surrounding each repair weld, and substantially lower residual stresses existed in the weld metal itself.
\end{abstract}




\section{INTRODLCT ION}

Th.e structural lategrity of steel pressure vessels that could conceivably be flawed has been the subject of extensive research and testing in a number of major industries. This concern has been particularly acute in the nuclear industry, which is characterized by the need to ensure the integrity of thick-walled pressure vessels that contain reactor cores and cooiant. The Heavy Section Steel Technology (HSST) Program at the Dak Ridge National Laboratorv (OR!I) was instituted to accelerate analytical and experimental investigationa of thick-section pressure vessels nade from representative nuclear reactor steels. The residual stress neasurement work that is reportec here was concucted in support of the HSST program intermediate vessel tist ef fort.

The ident ffication of a flaw in an operating nuclear power plant would present the plant rowner with a problem requiring imsediate attention. For example, if it could be shown by analysis using procedures specified in the Boiler and Pressure Vessel Code' that the flaw were sufficiently small compared with the size of a critical flaw, the owner would probably be allowed to continue normal operation of his plant. (This practice of continued operation of equipment with known safe flaws is not unusual in the aircraft industry.) If, on the other hand, an analysis of a flawed vessel indicated a margin of safety that was less than that allowed, the owner would then be faced with the prospect of ceasing operations and making an acceptable repair if possible.

Because there is this possibility of a flawed vessel requiring some form of corrective action, activities have been under way for some time to provide the technical basis for effective and proven corrective measures. A trequently mentioned corrective measure involves the removal of the flawed region of the vessel by grinding. The cavity thus created could then possibly be left alone since the sharp crack tip would have been removed; or if analysis were to show that the remaining wall thickness was less than acceptable, the cavity could then be filled with weld metal, and the vessel could thereby be returned to its original dimensions. A weld repair of this type would, of course, be a very difficult in situ operat1on. Normally high-temperature thermal stress relief is given to nuclear 
vessels atle: tabrication welding as a peans to reduce stresses induced during assembly. A heat treatment under field conditions could, however, result in severe difficulties associated with thermal expansion and warpage. Consequently, the American Society uf Yechanical fingineers (ASME) in Section $X I$ of the Boiler and Pressure vessel Code' has provided a procedure for making riajor repairs without subsequent thermal stress relief. The procedure (paragrafh IWB- $\$ 420$ of the code) employs a technique known as the half-bead technique which operates on the principle that the teapering of each layer of weld bead is accomplished by subsequent weld beads. The work reported here is intended to provide an experimentally based assessment of the magnitudes and distributions of the residual stresses in and around large half-bead weld repairs in thick-section, reactor presssurevessel steels.

The residual stress measurements reported here were made on chree different welds in two different thick-walled test vessel configurations that either have been or will be pressure tested as part of the HSST expcrimental test program. In addition to the pressure vessel repair welds, three qualification welds were made on two thick-walled cylindrical sections known as prolongations. A summary of the vessels and prolongations that were used for the weld repair studies is given in Table 1.1. Both the vessels and the prolongations, which are described in Chapter 2, were made from A533, grade B, class 1, low-alloy steel plate. A description of each of the weld repairs is contained in Chapter 3 . The residual stresses were determined by means of weldable strain gages which had been placed on the vessel and prolongation surfaces and which were read before and after the weld repair and the hole-drilling technique that was used

Table 1.1. Summary of vessels and prolongations used for the weld repair studies

\begin{tabular}{cccc}
\hline Test specimen & Repair weld & Prolongation & $\begin{array}{c}\text { Qualification weld } \\
\text { (simulation) }\end{array}$ \\
\hline$V-7$ & $V-7 A$ & $V-9$ & $V-7 A$ \\
$V-7 A$ & $V-7 B$ & $V-8$ & $V-7 B$ \\
$V-8$ & $V-8$ & $V-8$ & $V-8$ \\
\hline
\end{tabular}


to obtain surface and through-thickness results. iretails of tive aeasurement methods are contained in Chapter i. Chaprer 5 describes the sectioning of the prolungat lons that was done to allow the through-thicikness determination of residual stresses. Since sectioning (which in this case was done by sawing) will relleve stresses (at least the polisson concribution from stresses normal to the cut plane), a correction based on beasurements taken during sectioning was determined. The correction is also described in Chapter 5 . Chapter 6 contains a sumary of the residual stress measurements for all six welds. All of the through-thickness results in Chapter 6 contain the corrections for sectior.ing described in Chapter 5. Uncorrected results such as radial residual stresses and results not contained in Chapter 6 are contained in Appendices C, D, E, F, and C. Chapter 7 contains the conclustons from this work.

Repair welds and associated residual stress measurements with $v-7$ in their titles refor to weld repairs penetrating entirely through the 152-m (6-in.) specimen wall, and $V-8$ repair welds pertain to repairs made from the exterior surface of the vessel and penetrating slightly over halfway or $89 \mathrm{~mm}$ ( $3.5 \mathrm{in.}$ ) through the specimen wall. The repair welds described in this report were the result of cooperative efforts involving ORNL, the Electric Power Research Insticute (EPRI), Combustion Engineering, Inc. (CE), the Westinghouse Tampa Division (WTD), and the Advisory Task Group on Weld Repairs of the Pressure Vessel Research Comnitcee (PVRC). In addition, the bulk of the hole-drilling residual stress measurements macie on the $V-7 A$ simulation, ipair weld were made at the Westinghouse Research and Development Center (WRDC).

\section{Reference}

1. American Society of Mechanical Engineers, Section XI, Rules for InService Inspection of Nuclear Power PLant Components, ASME Boiler and Pressure Vessel Code, American Soclety of Mechanical Engineers, New York, July 1, 1974. 


\section{DESCRIPTION OF IESJELS AND PROLONGATIONS}

This chapter describes the two thick-walled pressure vessels and the two qualification pieces which contained six repair welds and were used in the residual stress studies reported here. HSST intermediate test vessel $\mathrm{V}-7$ contained two repair welds wade at different $t$ imes and designated $V-7 A$ and $V-7 B$, respectively. HSST incermediate test vessel V-8 contained a single repair weld designated $v-8$. The configuration and dimensions of the identically shaped $v-7$ and $v-8$ vessels are shown in Fig. 2.1. Each of the three repair welds made in an intersediate test vessel

OPNL-DWG 70-320

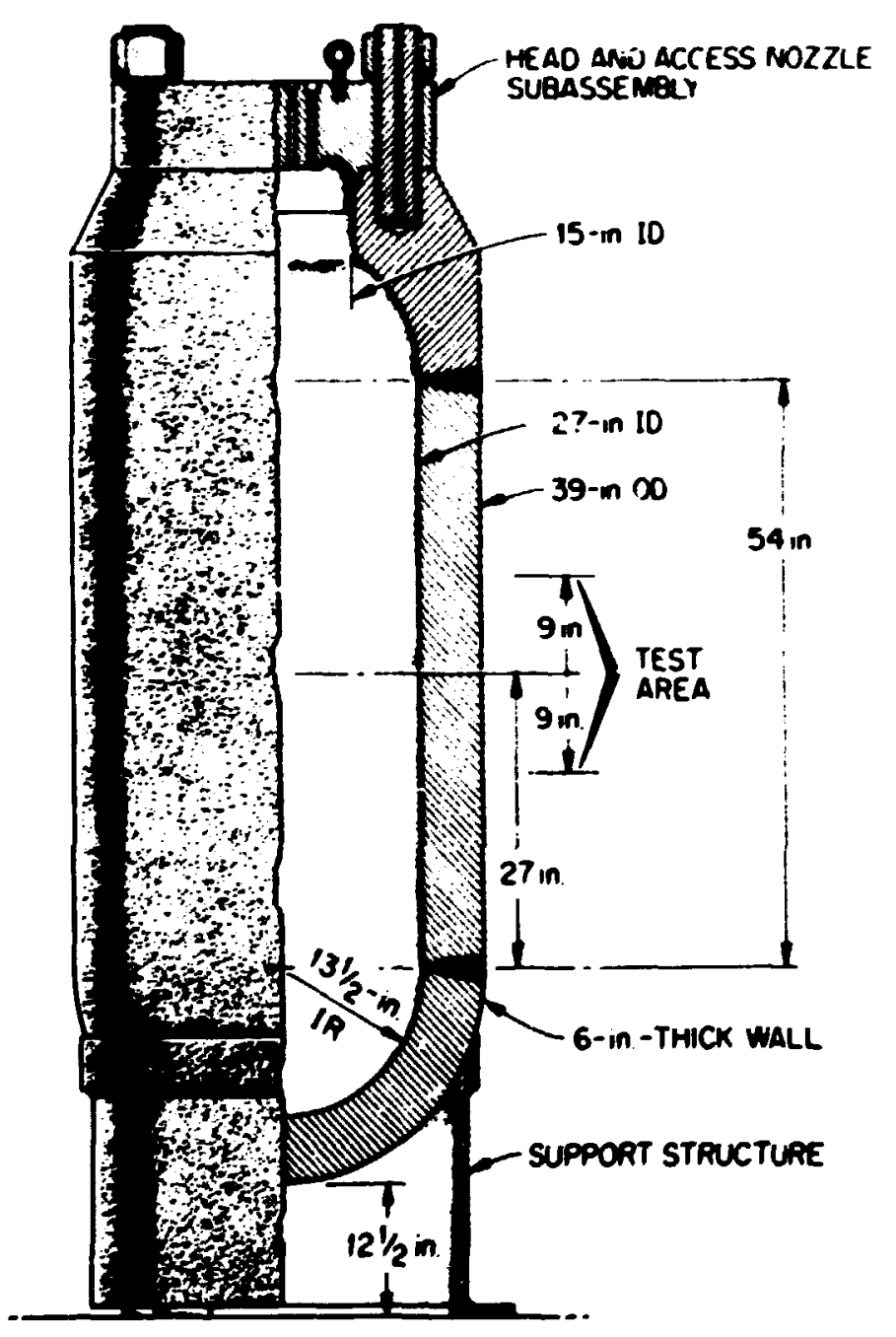

F18. 2.1. HSST internediate vessel (1 in. $=25.4 \mathrm{mn})$. 
had an associated qualif ication repair weld in a prolongation which was a 0.n4-m-long (25-in,) right circular cylinder with the same material properties, nominal wall thickness, and nominal radii as those of the intermediate test vessels. The qualification welds are known as the $V-7 A$ simulation, the V-7B simulation, and the V-B simulation. The V-7A repair weld and the $V-7 A$ simulation weld in the vessel $V-9$ prolongation were made by Combustion Engineering in Chattanooga, Tennessee. ${ }^{2}$ The V-7B and V-8 repair welds and their corresponding simulation welds made in the vessel V-8 prolongation were fabricated by the Westinghouse Tanpa Division. 2 Figure 2.2 shows vessel $V-7$ as received at CE prfor to beginning the $V-7 A$ zepair weld, and Fig. 2.3 shows the V-9 prolongation at CE prior to the excavation of the cavity for the $V-7 A$ simulation weld. Figure 2.4 shows vessels $V-7$ and $V-8$ and the $V-8$ prolongation prior to their shipment to WTD for the $V-7 B$ and $V-8$ repair and sioulation welds. The $V-7 B$ and $V-B$ simulations were located $180^{\circ}$ apart in the same prolongation as shown in Fig. 2.5.

The cylindrical shell courses for vessels $V-7$ and $V-8$ and the prolongations used for the simulated repair welds were fabricated from ASTM A533, grade B, class 1 steel plate produced by Lukens Steel Company from a single heat identified as B523-2. Chemical analysis reported for this heat is as follows:

Ladle analysis (wt $z$ )

$\begin{array}{ccccccc}C & \text { Mn } & P & S & S i & N i & \text { Mo } \\ 0.2 & i .23 & 0.015 & 0.017 & 0.26 & 0.49 & 0.52\end{array}$

After being rolled to their cylindrical shape and prior to making the axial seam welds, the shell courses and prolongations were typically subjected to heat treatments consisting of austentizing at $899^{\circ} \mathrm{C}\left(1650^{\circ} \mathrm{F}\right)$ for $61 / 2 \mathrm{hr}$, quenching in agitated water, teapering at $682^{\circ} \mathrm{C}\left(1260^{\circ} \mathrm{F}\right)$ for $61 / 2 \mathrm{hr}$, air cooling, and stress relleving at $621^{\circ} \mathrm{C}\left(1150^{\circ} \mathrm{F}\right)$ for $30 \mathrm{hr}$. The cylinders were completed by subwerged-arc welding. These weldments were then subjected to an intermediate postweld heat treatment at typically $593^{\circ} \mathrm{C}\left(1100^{\circ} \mathrm{F}\right)$ for $11 / 2 \mathrm{hr}$. Tensile test data results at $25^{\circ} \mathrm{C}$ and $93^{\circ} \mathrm{C}\left(77^{\circ} \mathrm{F}\right.$ and $\left.200^{\circ} \mathrm{F}\right)$ from both tangentially (C) and axially (A) oriented specimens are shown in Fig $2.6 .^{3,4}$ Further detalls regarding 


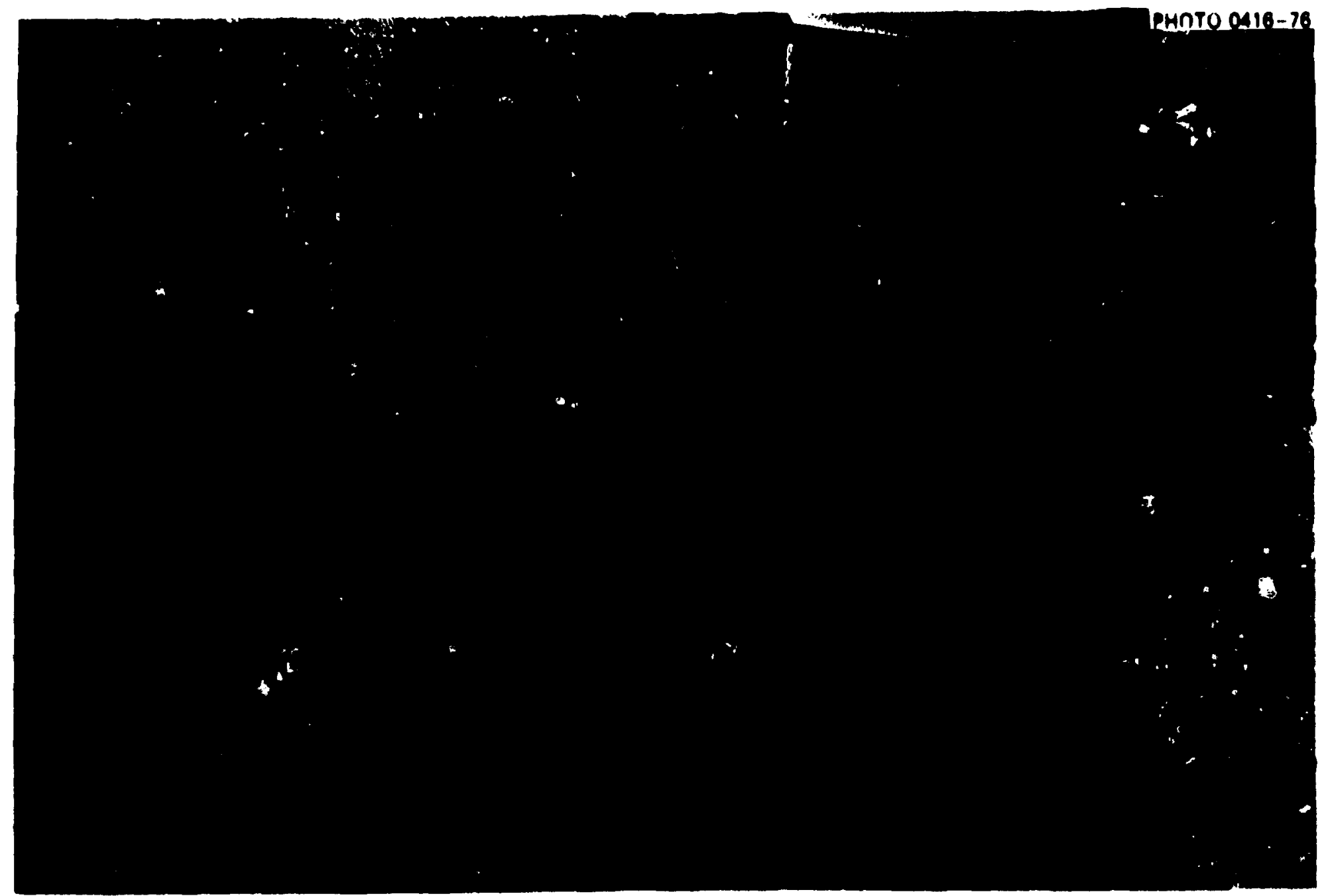

F1g. 2.2. Vessel $V-7$ as received at Combustion Engineering ( 1 in. $=25.4 \mathrm{~mm})$ 


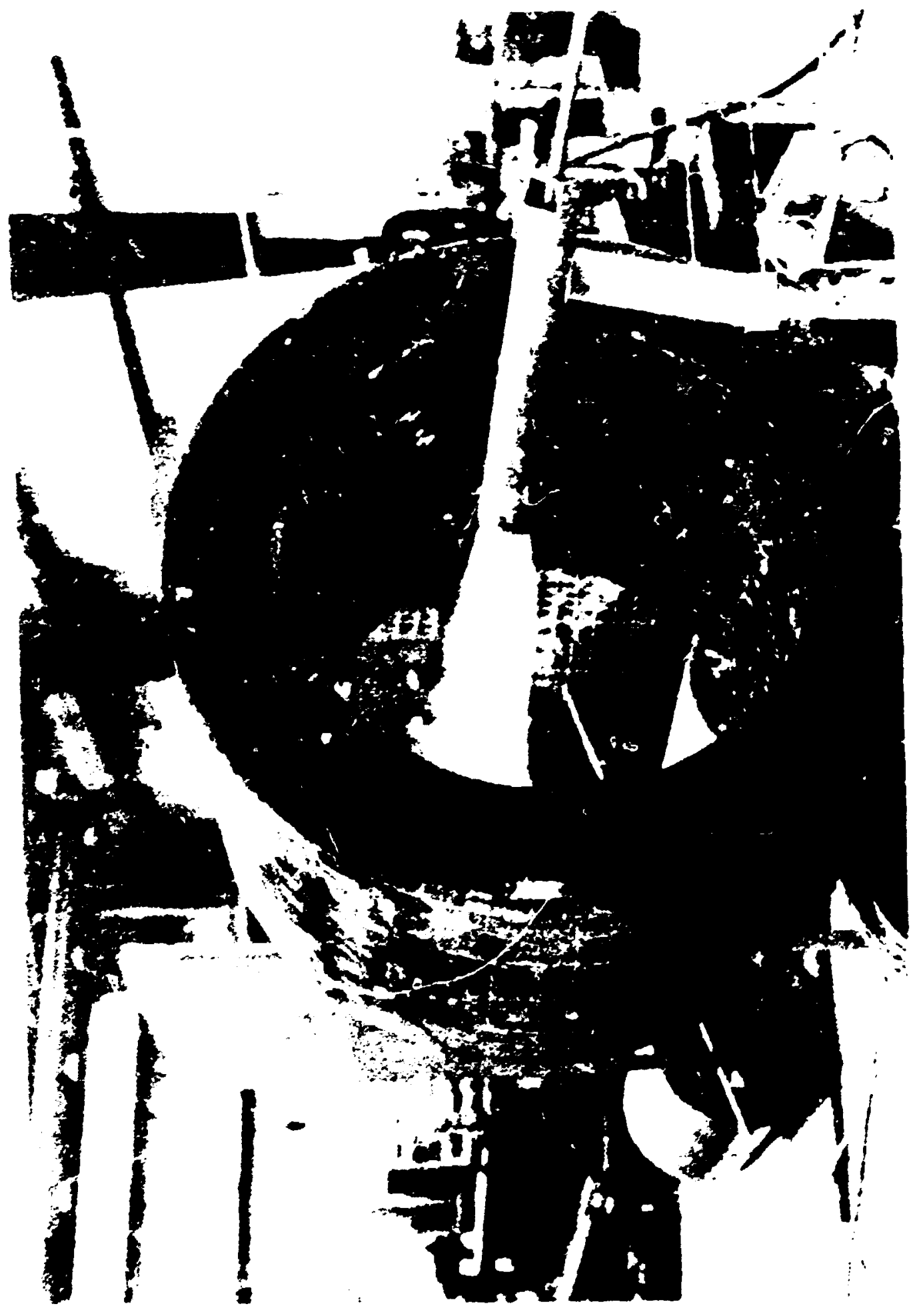




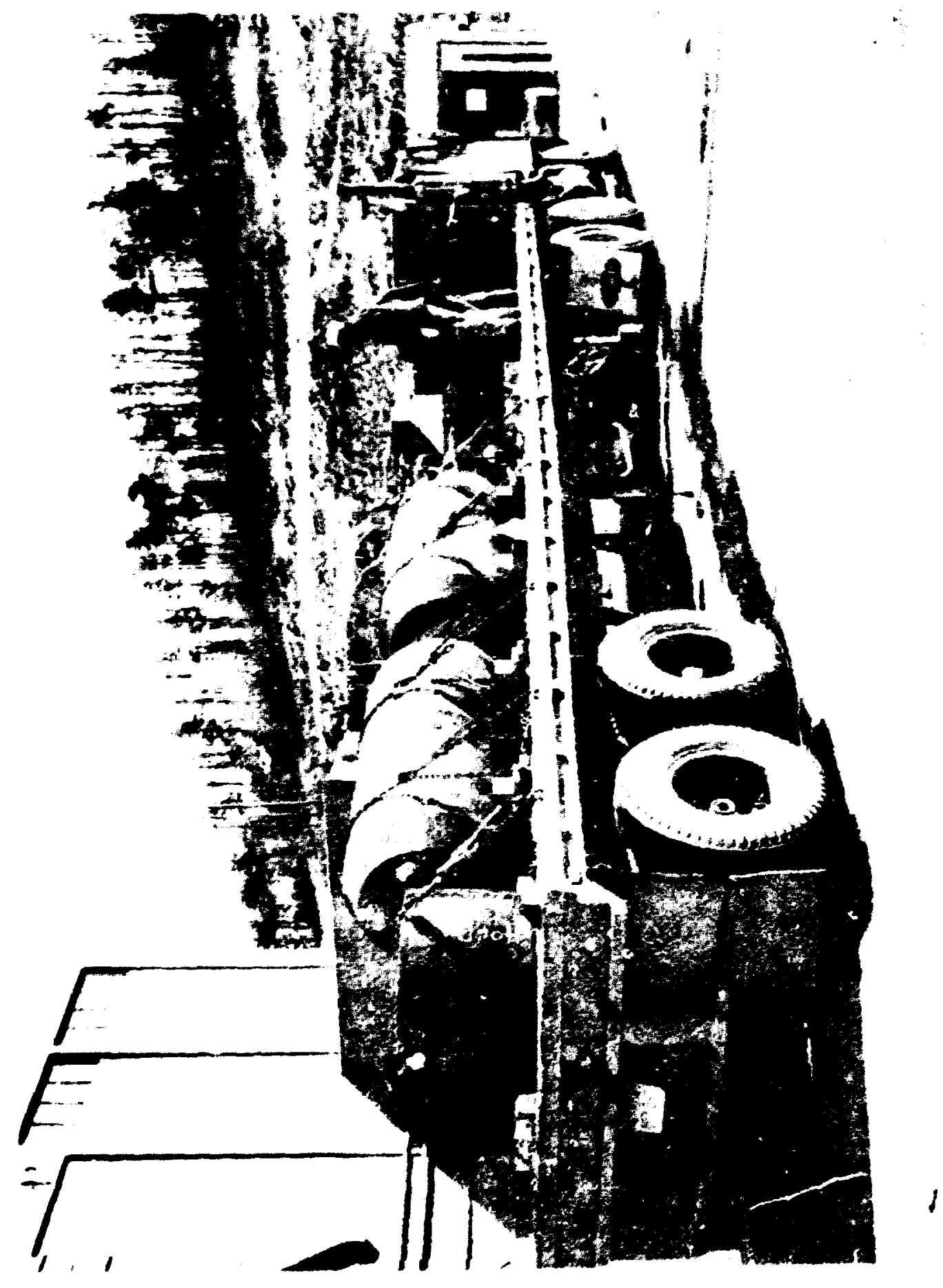




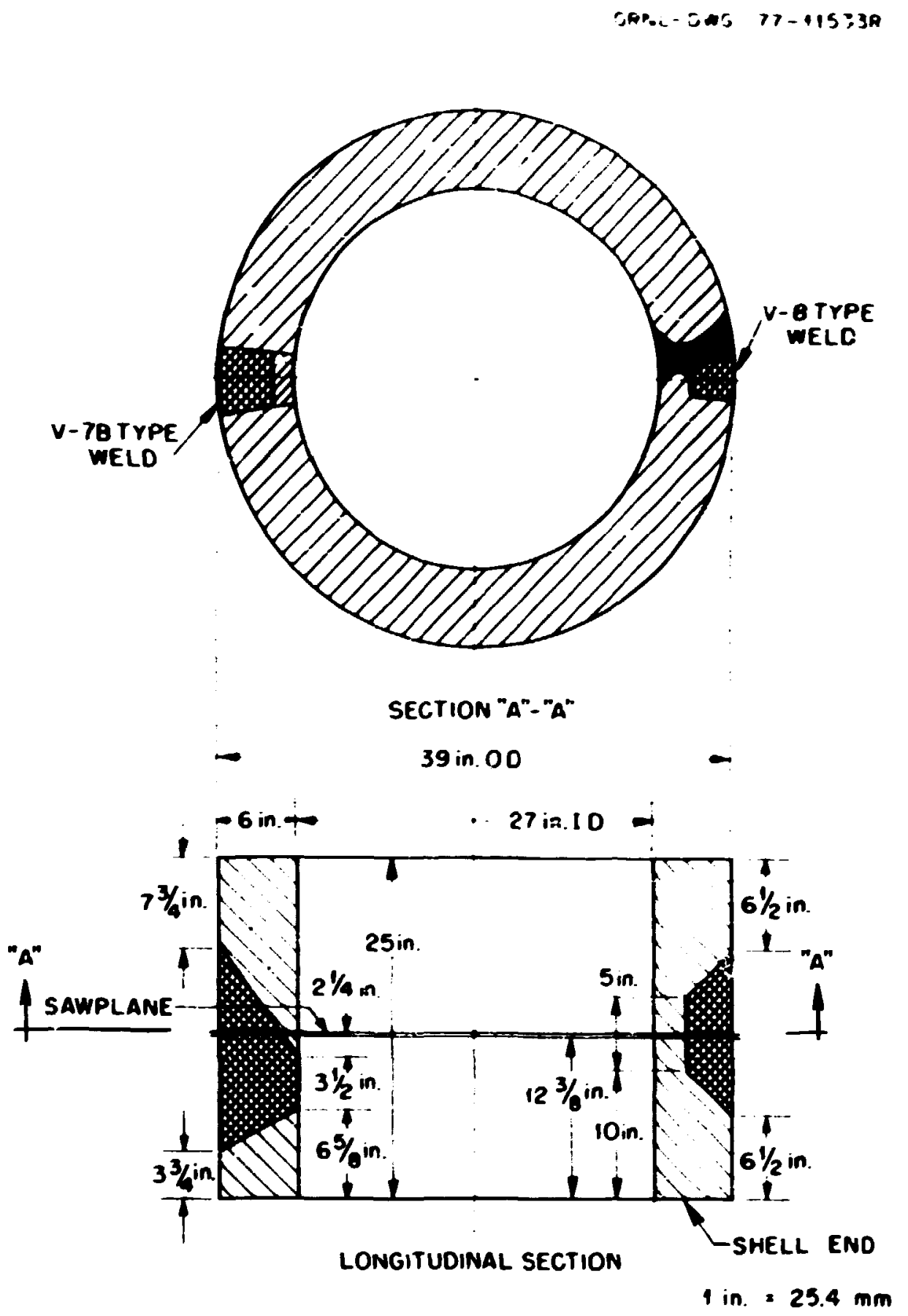

Fig. 2.5. The V-8 prolong,ation that was used for the $V-7 B$ and $V-8$ simulation repair welds. 


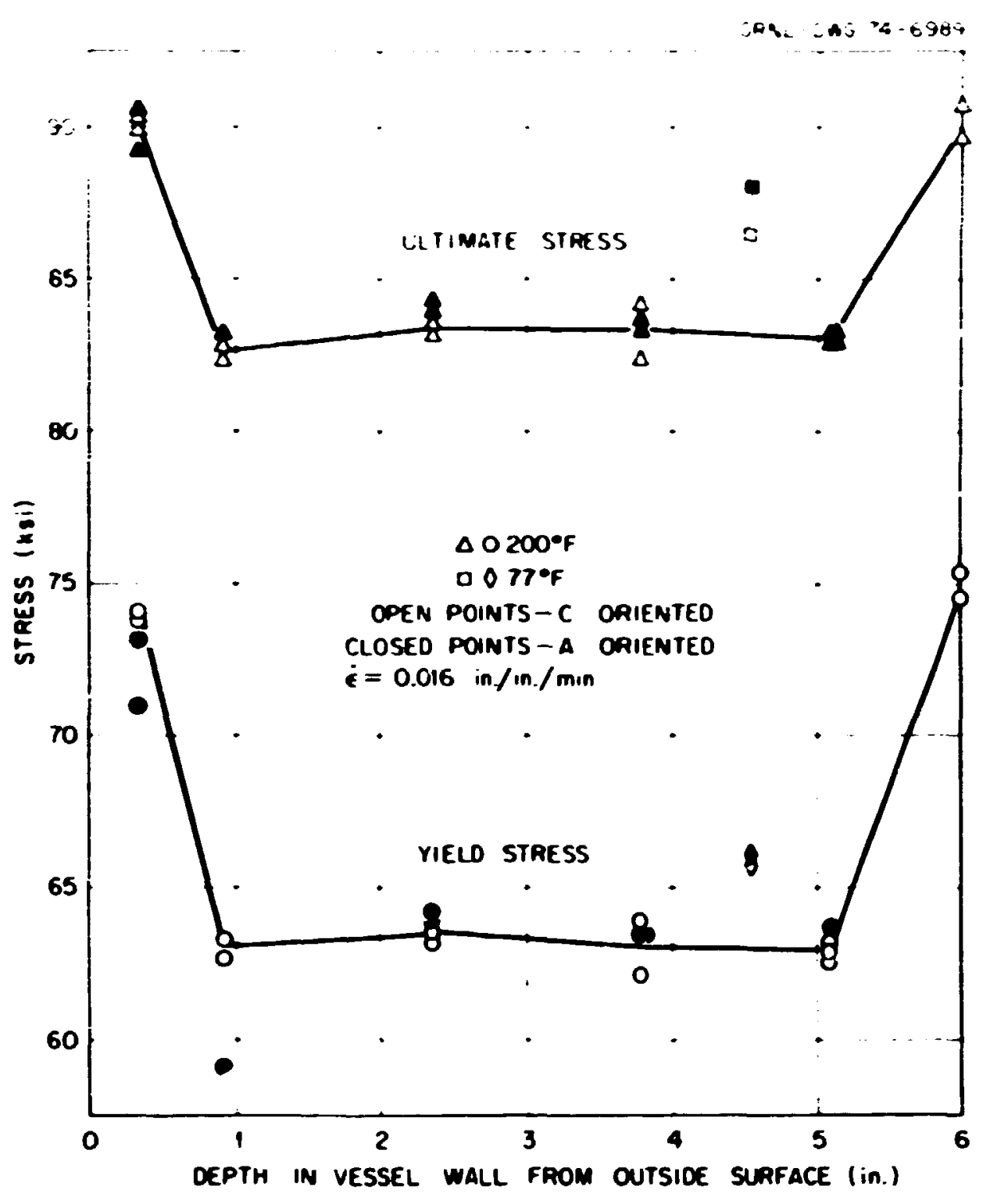

Fig. 2.6. Tensile properties of intermediate vesse: $V-7$ using Cand A-oriented subsize tensile specimens from 152-mm-thick (6-:n.) ASTM A533, grade B, class 1 carbon steel ( $1 \mathrm{ksi}=6.895 \mathrm{MPd} ; 1 \mathrm{in} .=25.4 \mathrm{~mm})$.

fabrication and material properties can be found in Refs. 5 and 6 . The $V-7$ and $V-8$ vessels were machined to contour after the final stress relief and thereby a skin effect (i.e., shallow compressive residual stresses) was induced. Details of investigations relating to the skin effect are cont-ined in Appendix $G$. 


\section{References}

1. H. D. Goins and D. L. Butler, Held Repair of Heavy-Section Steel Jechnology Progran Vessel V-?, EPRI NP-179 (August 1976).

2. P. P. Holz and S. W. Hismer, Half-Bead (Temper) Repair Welding for Heavy-Section steel Technology Pragran Vessels, ORrL/NuREG/M-177 (to be published).

3. W. J. Stelizana, "Characterizat ion of Intermediate Test Veseel Materials," HSST Progran Semiannual Progress Report, Aug. 31, 1973, ORNL-4971, PP. 66-74.

4. H. J. Stelzan, "Characterization of Internediate Test Vessels," Quarterly Progreas Report on Reactor Safety Programs Sponsored by the Division of Reactor Safety Rebearch for April-dune 1974, 0RN/TH-4655, Vol. II, PP. $56-66$.

5. J. C. Merkle et al., Test of 6-in.-thick Pressure Vessels. Series 3: Intermediate Fest Yessel V-7, ORUL/NUREG-1 (August 1976).

6. C. E. Childress, Falrication and Mechanical Test Data for the Four 6-in.-thick Intermediate Test Vesselo Made from Steel Plate for the Heavy-Section Steel Technology Program, ORNL/TM-5074 (January 1976). 
Vessel $v-7$, the eighth $4 S S T$ thick-walled pressure vessel tested, failed as predicted in a leak mode. A description of the test and results can be iound in Ref. :. Although the fallure occurred well above the vessel's design pressure and extensive yielding had occurred, the vessel remained essentially intact and could thus be reused for a subsequent test provided the original flaw, which consisted of the deep, sharpened machined groove shown in Fig. 3.1, was repaired. Figure 3.2 shows the pressure vessel after completion of the first test known as the $V-J$ test. Since a high-quality repair was required for anticipated additional high-pressure testing and there was considerable interest in repair welds that did not include high-temperature postweld stress relief, it was decided that the weld repair would be perforned in general accordance with "Procedire Number 4, Nelding Low Alloy Steels," of Section XI,

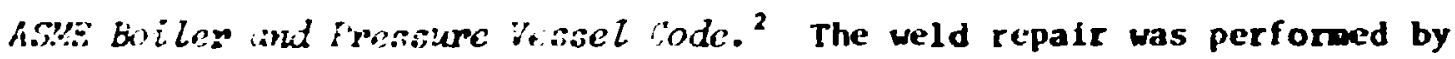

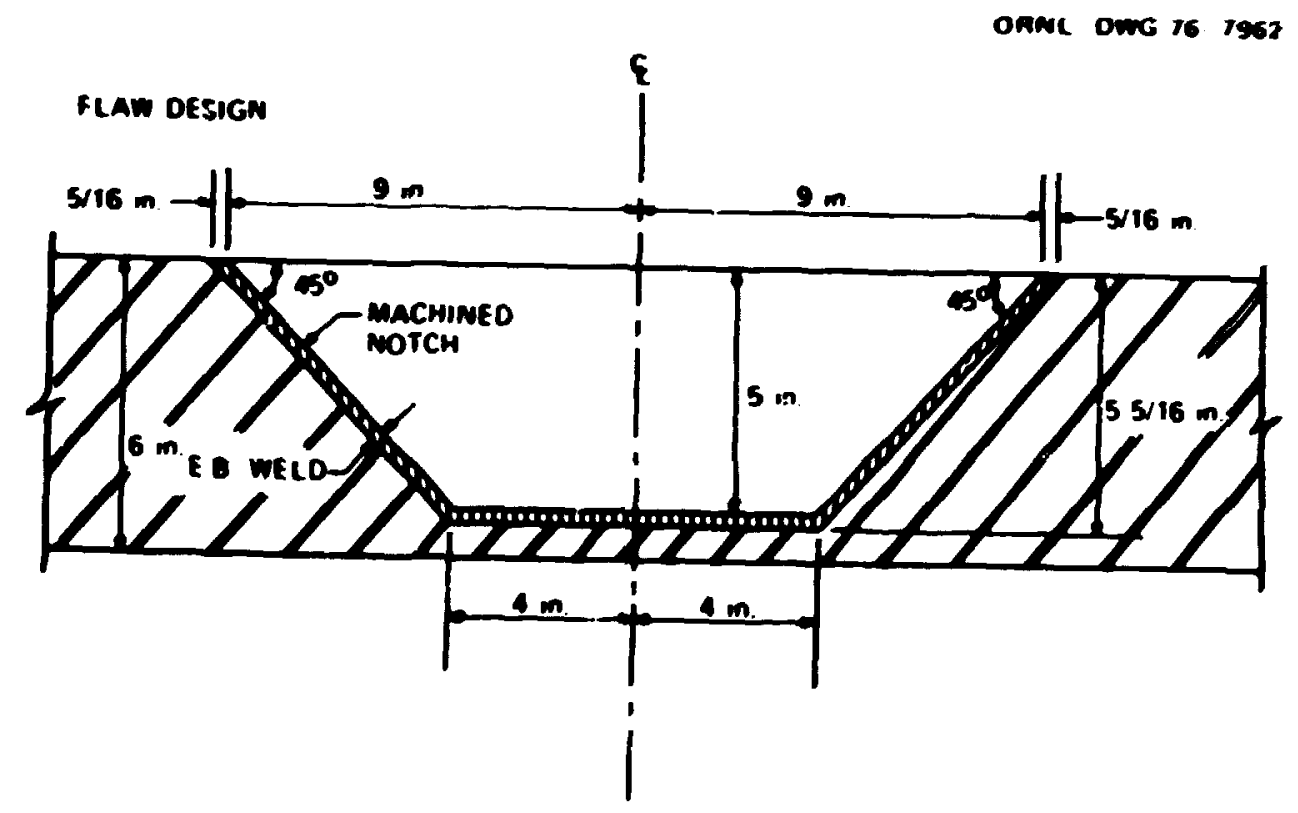

Fig. 3.1. Flaw design for HSST program intermediate test vessel $V-7$ (1 in. $=25.4 \mathrm{~mm})$. 


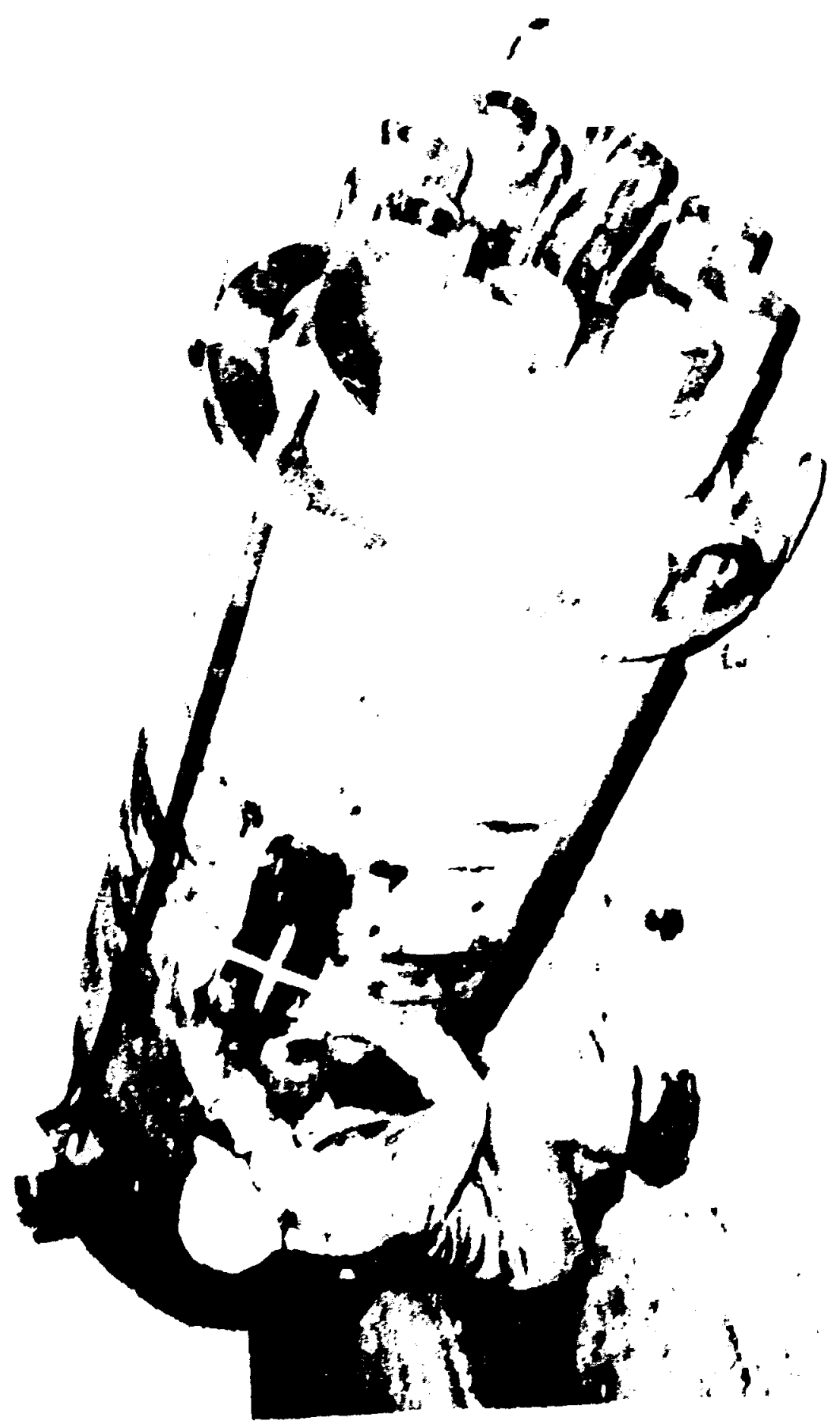




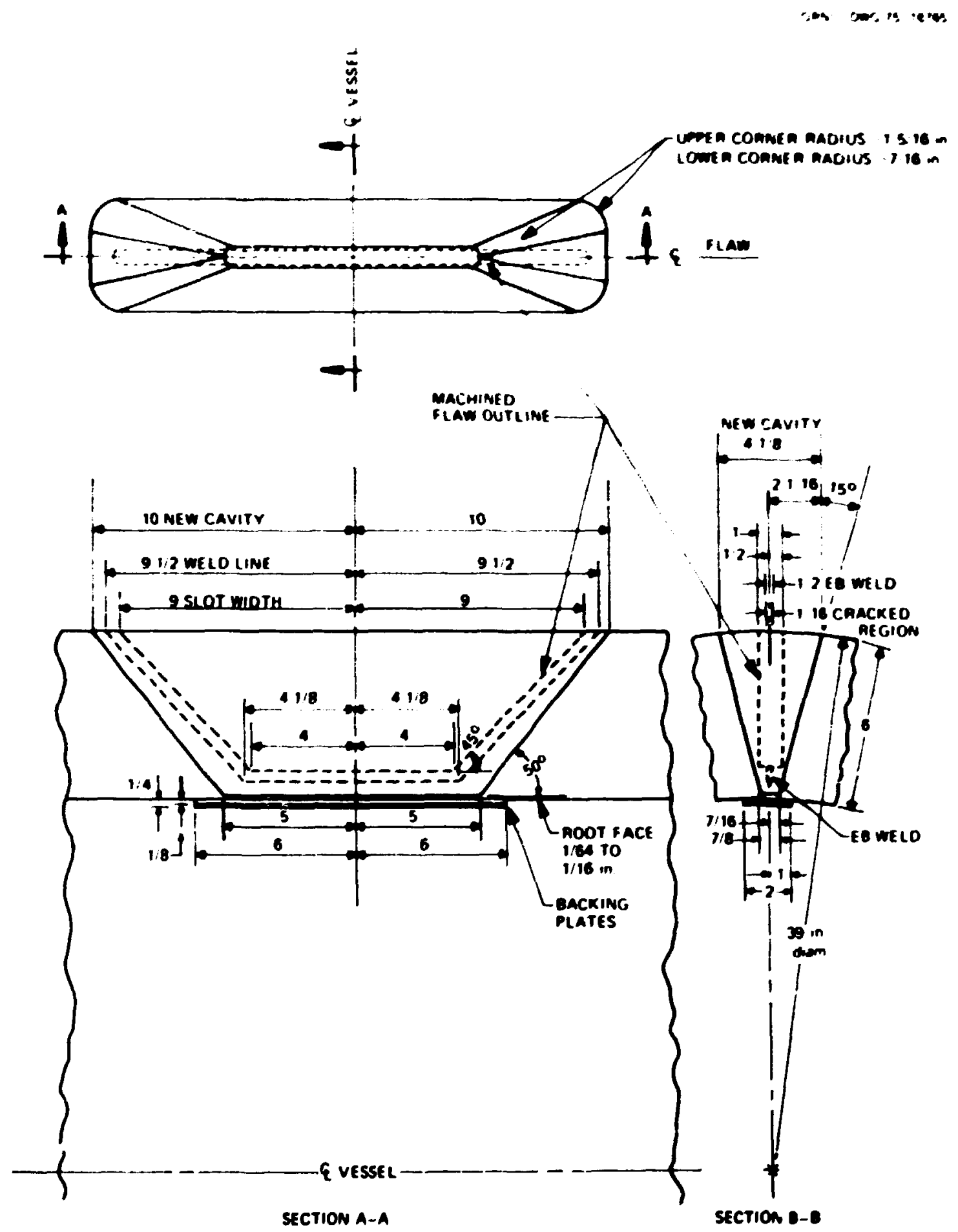

Fig. 3.4. Weld repair preparsition cavity in vessel $V-7$. Weld repair for V-7A. Dimensions are approximate and are $g$ iven in inches (1 $\mathrm{in}$. $25.4 \mathrm{~mm})$. 


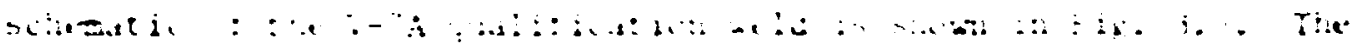

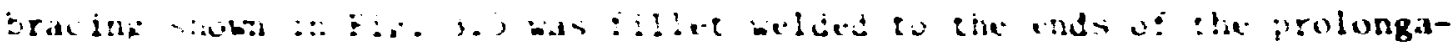

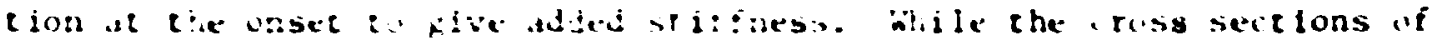

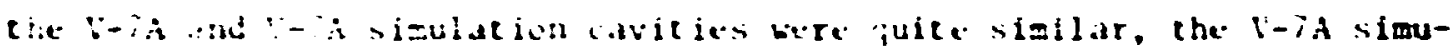
bation be!d avity whs shorter tian that wi the I-iA. This compromise was made so that a sifnificant abunt of base netal remained between the ends of the prolongation ard the repair beld.

(wins and Butlar ${ }^{\prime}$, have published a comprehensive report on the CE $b-7 \dot{a}$ and $V-i d$ simulat for. repair weld operations. A brlef sumary a: fiose operatiens fullows. In order to ensure complete reaval of the airarc surface and any heat-affected zone resulting irom the air-arc process, a minimua of 6 (0.25 in.) of base metal hits ground frum the surface of the cavity. Resistance heaters were then applied to the $V-7$ vessiel and

OAML-DNG $78-3971$
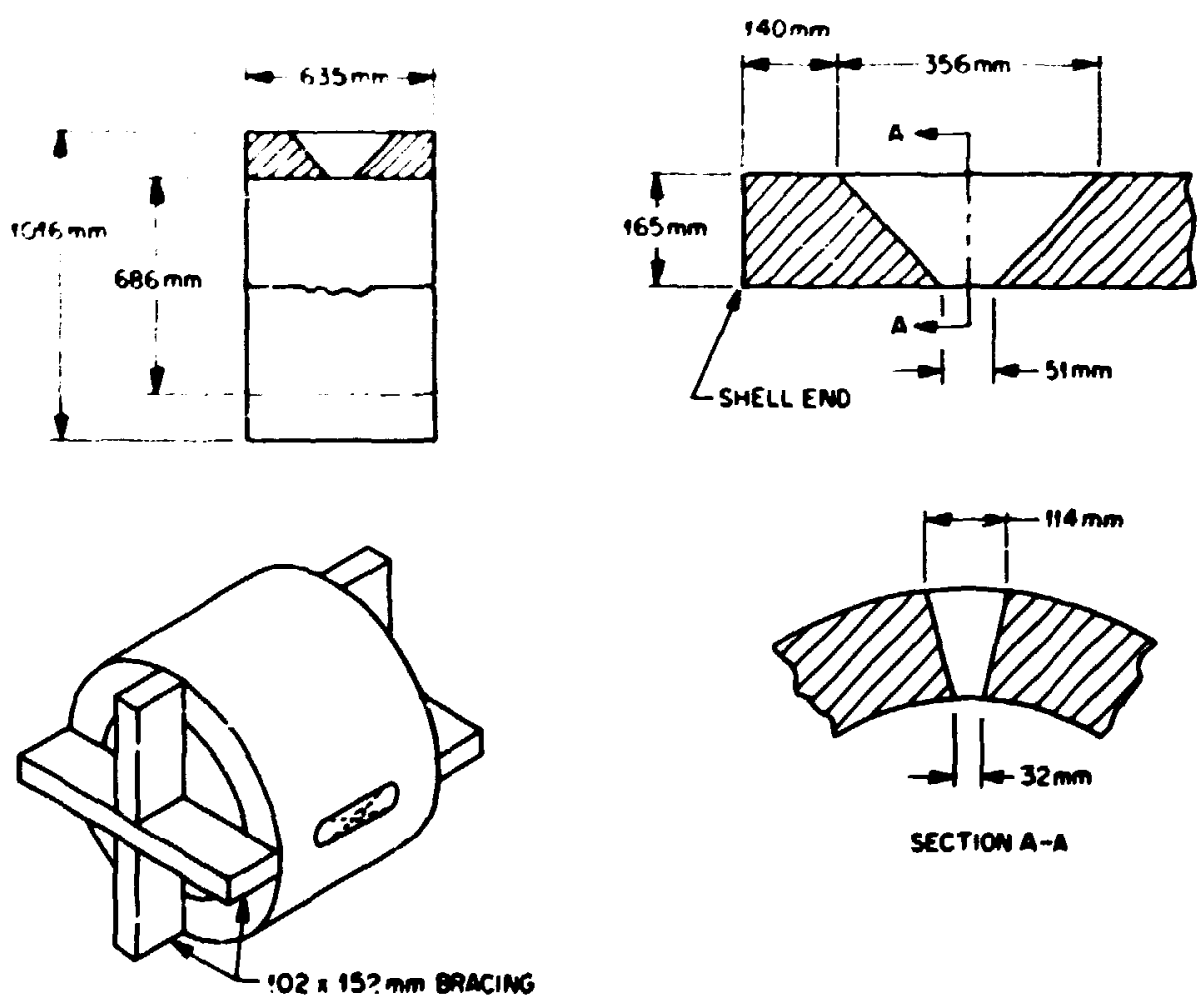

SECTION A-A

Fig. 3.5. V-7A simulation repair weld cavity, V-9 prolongation $(1 \operatorname{mon}=0.0394 \mathrm{in.})$. 
the prolungar fun for a prebeat. Appruxialtely; fir arere requited to solng

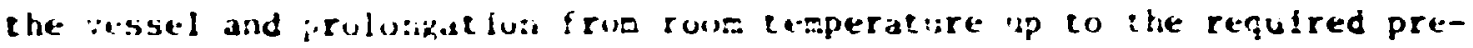

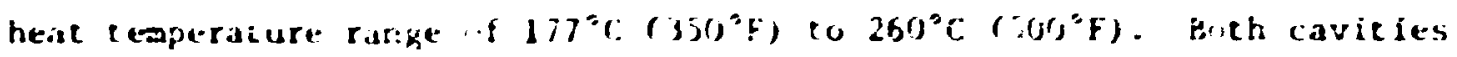

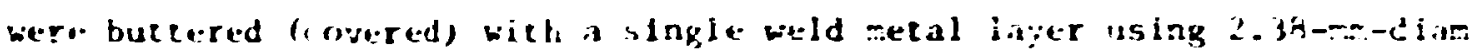
(3/3i-1n., -lectrud.s. Approximately une-ialf of this airst layer was

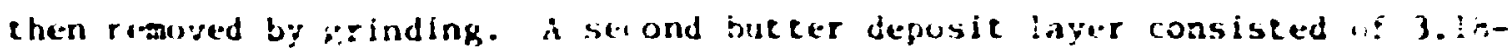

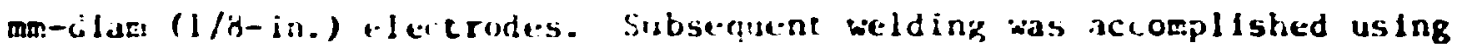
3.14- ind ?.97-mm-diam (1/4- and :/32-in.) electrodes. Fipor irmpletion of the weld repair, final arow pass sistaces atere prounc and the vegsel

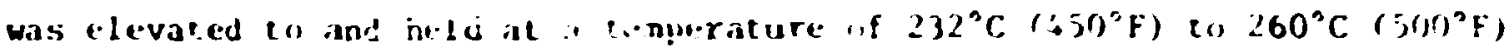
for : hr. (E) welding was performed in ilie llat position with the vessel and prolungat $i \cdots$ axes horizontal. $\therefore$ cross section of the $V-7 \lambda$ simulation weld is shown in fig. 3.h. The rariation of tensile properties with temperature for the brold metil used in the $\because-7 \lambda$ and $V-7 A$ simulation repair welds is shown in Fig. 3.7."

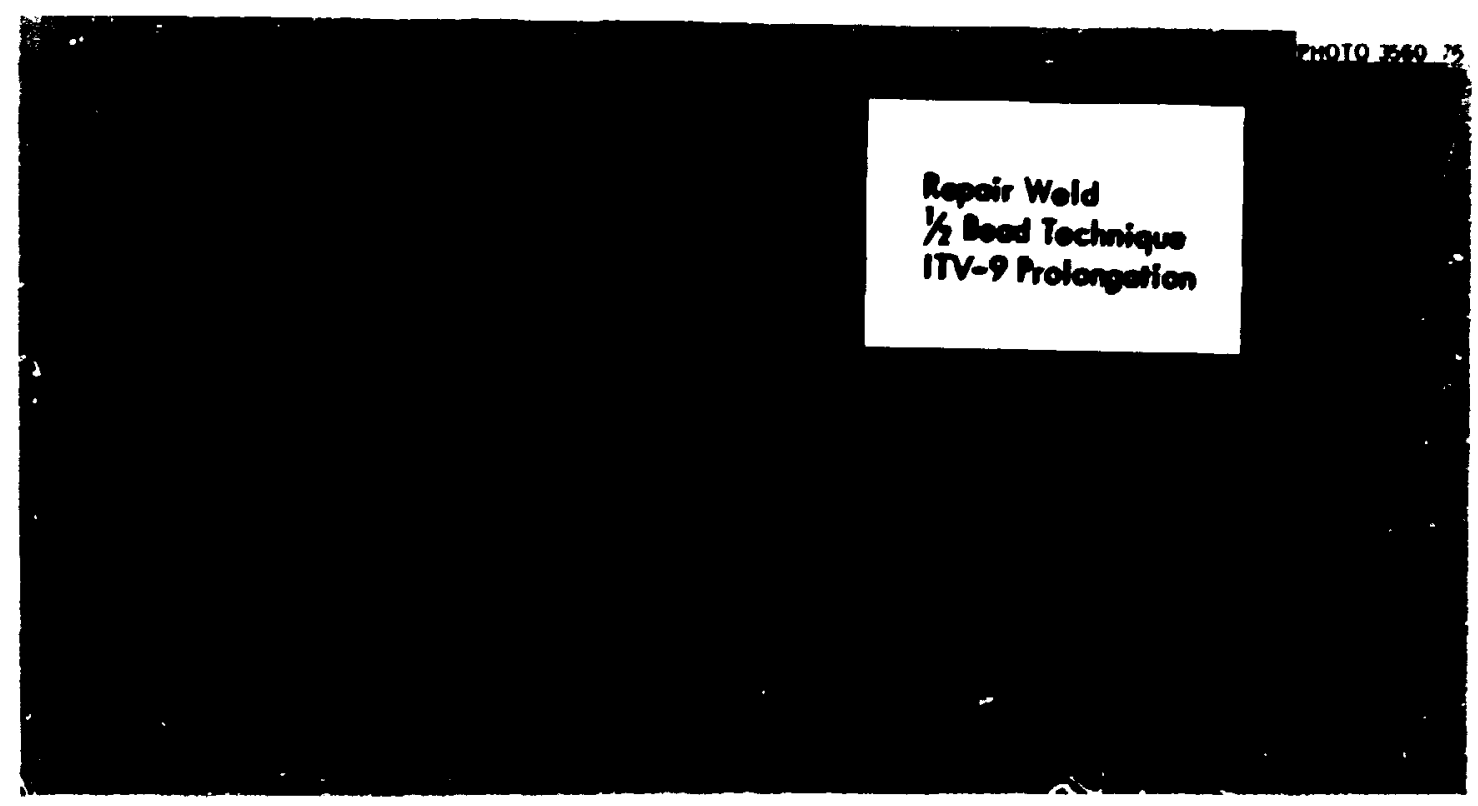

Fig. 3.6. Cross section of a quarter segment of the $V-7 \Lambda$ simulation repair weld, $v-g$ prolongation ( $1 \mathrm{in.}=25.4 \mathrm{~mm}$ ). 


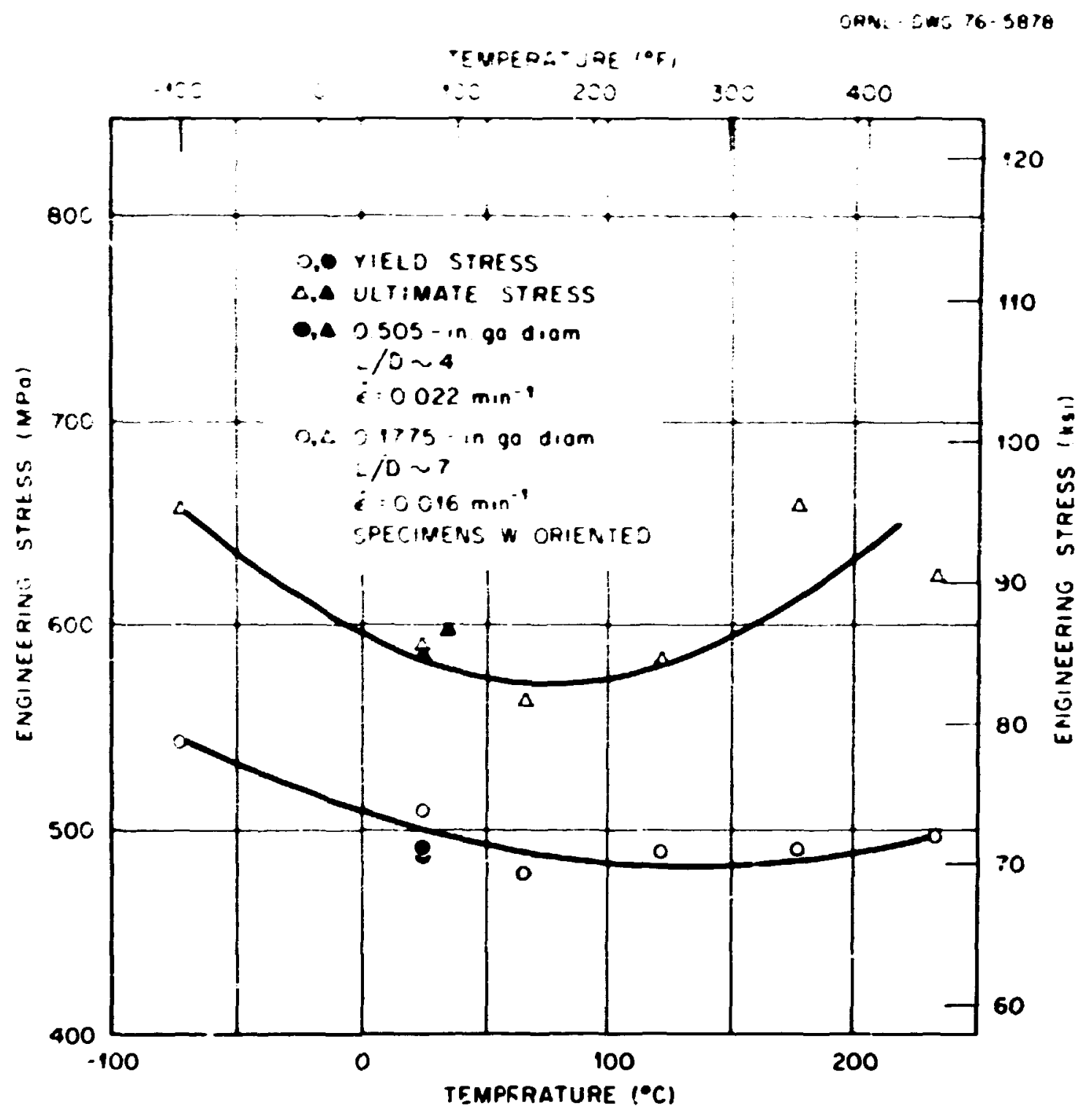

Fig. 3.7. Variation of tensile properties with temperature for the shiejded metal-arc weldment taken from the V-7A simliation repair weld, v-9 prolongacion.

\section{$V-7 B$ and V-7B Simulation Repair Welds}

The vessel designaced $V-7 A$ (i.e., repaired by $C E$ ) was intentionally flawed in base metal remote from the repair weld and tested in June 1976. (For details of the test see Ref. 6). The V-7A test was quite similar to the $V-7$ test in that the test temperature, flaw location, and flaw size 
were nearly identical. The significant differences between the tests were that $v-7 A$ hiad an ineernal patch in order to hold pressure once the flaw had torn through the wall, and $v-7$ in was presstizized pneuatically while $V-7$ was pressurized hydraulically. At the completion of the $V-7 A$ tost, the ressel remalned intact as it was after the Initial V-7 test. It was therefore pussible to repair the vessel again and perform yet a third test with it. Since repair welds were to be the subject of fur:her HSST research and development, it was decided that once again the ASME recomended procedure known as the half-bead technique would be specified to repalr the V-7A vessel, which, when repaired for the second tine, would be referred to is vessel $V-7 B$. The repair was performed by HTD. The welding procedure' at WTD was similiar to that performed at CE except that it was specified that the vessel and prolongation axes be aligned vertically during the veldiag uperation so that weld progression was in vertical passes. The prolongation used for a $V-7 B$ simulation repair weld was the V-S prolongation used by WTI for the V-r vessel simulation weld diseussed in the next siection. Cieneral dimensions of the vessel $V-7 h$ and prolongation $V-7 B$ simulation ravitie's ar" shown in Figs. $3 . K$ and 3.9.

Come-0.0 re-39ro
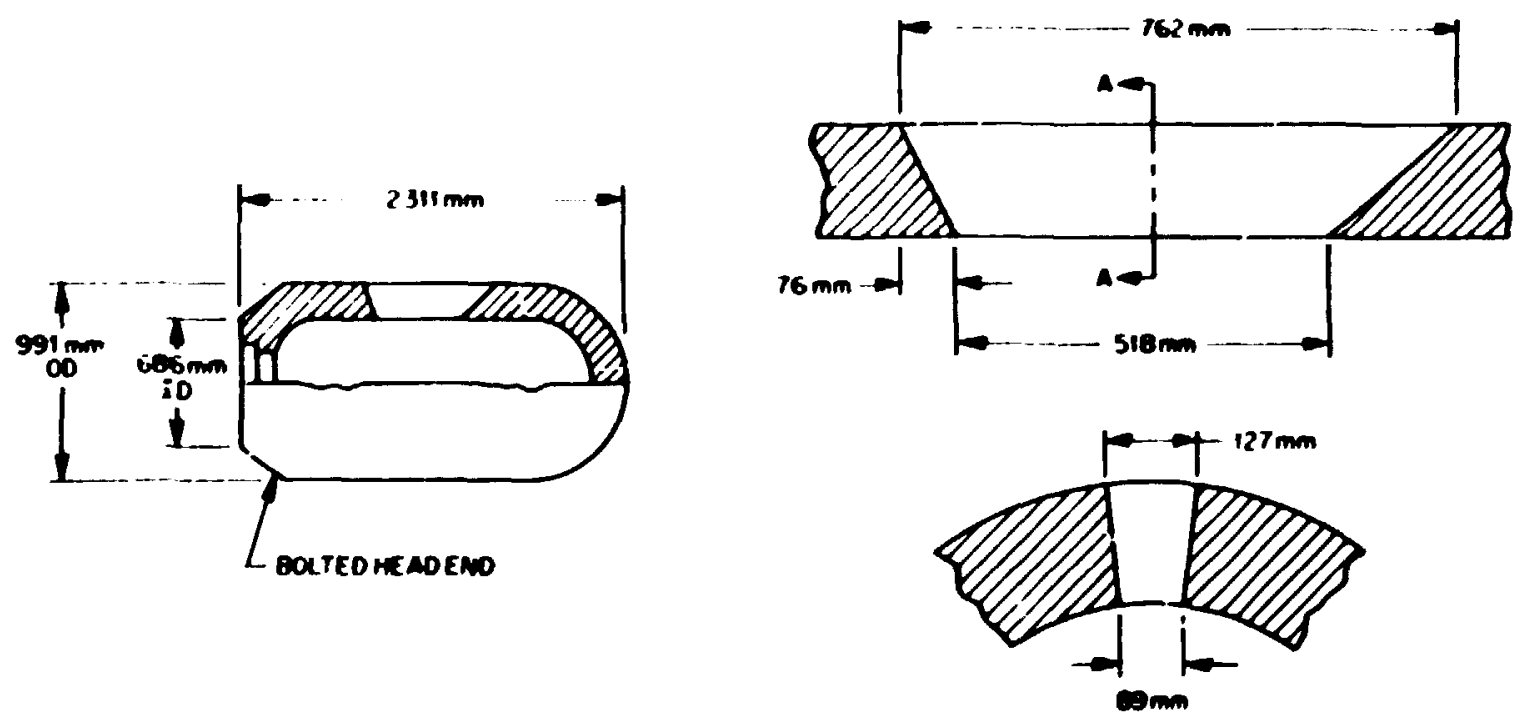

Fig. 3.8. Vessel V-7B repair weld cavity, $V-7 n$, vessel $(1=$ 0.0394 in.). 

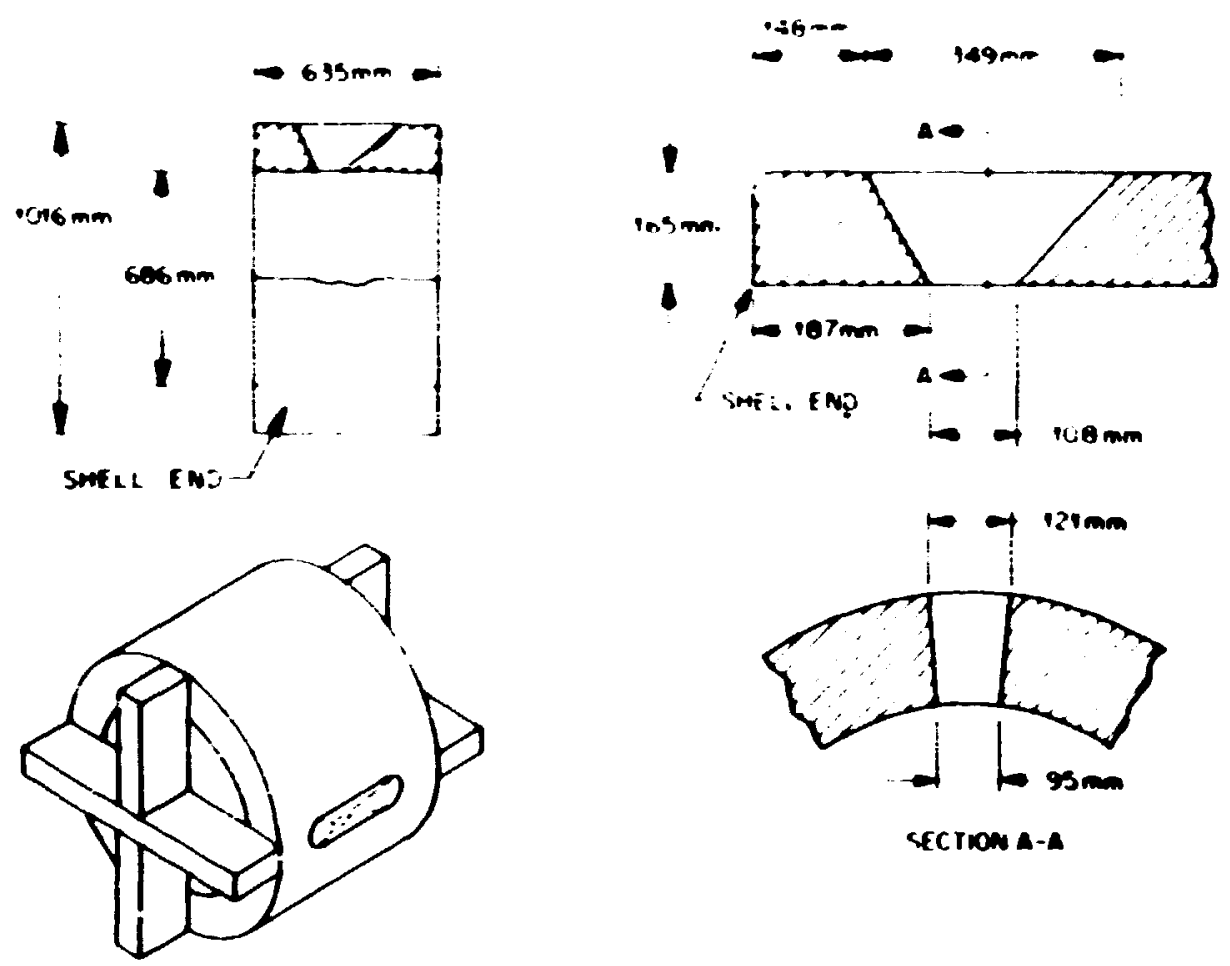

SECriona-A

Fik. 3.9. V-iB simulition repilir well cavity, V-8 prolongation (I $\operatorname{man}=(0.1134:$ in.).

and details of the V-7B weld cavity are simwn in Fig. 3.10. Buth throughwall ravities were of nearly ident ical width and end :ilope peometry; the overall length of the peolongat ion aivity, however, was ane-fith that of the vessel cavity. Muring welding at WTI, the bolced head end of the vessel and the sinelt enol of the prolongat fon were oriented downward. An extract of the welding specifilit ion describing weldiag procedures for $j-i$ is and $V-B$ repalrs is concained in Appendix $A$. A ross section of the $V-7 B$ simulation weld is shown in Fig. 3.11 .

\section{$V-B$ and $V-B$ Simulaciun Repair Welds}

Concurrent with the V-7B repair welds, WTD also made half-head repair welds referred to as the vessel $V-8$ and the prolongation V-r simulation. 

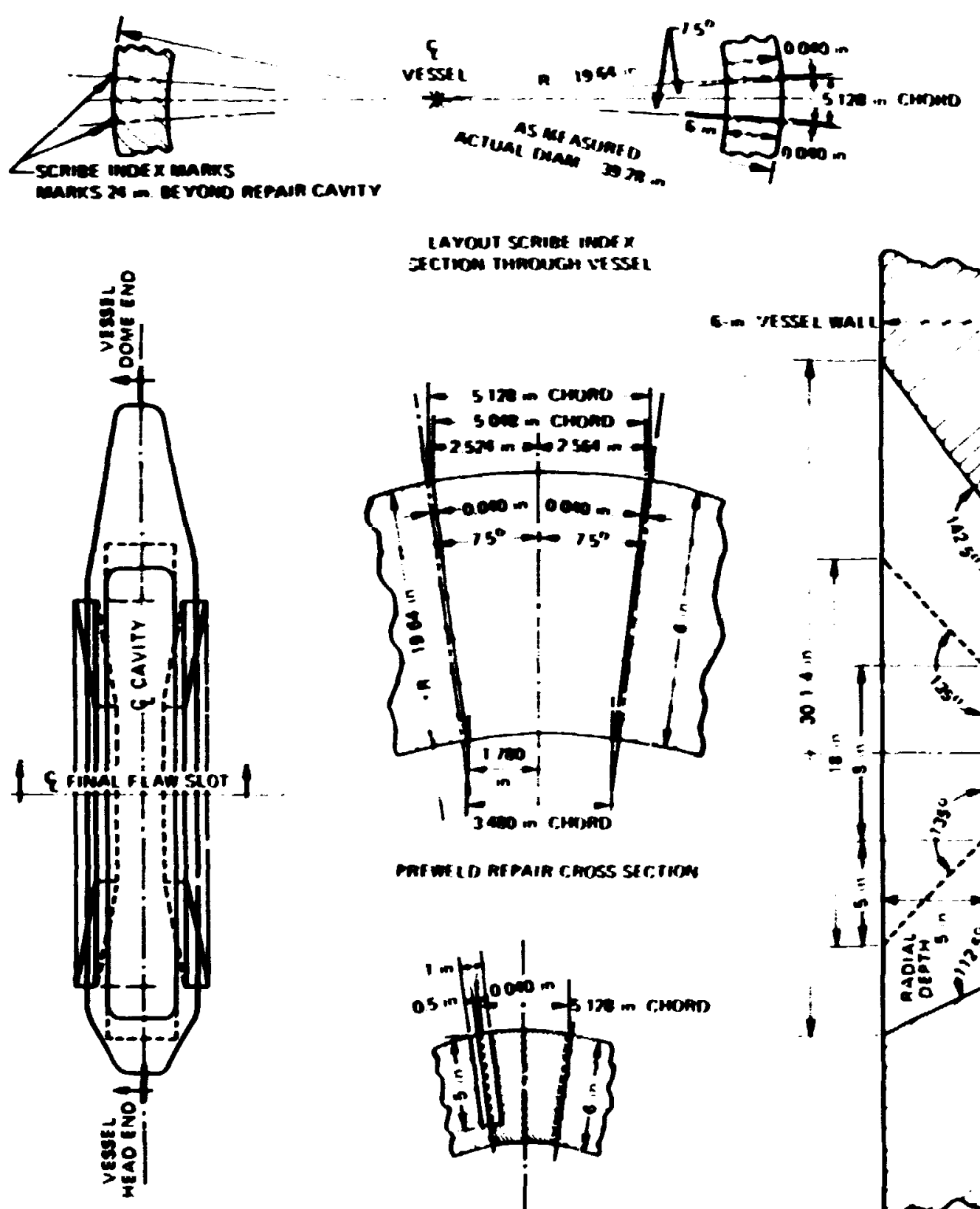

min wid armaik choss serinon
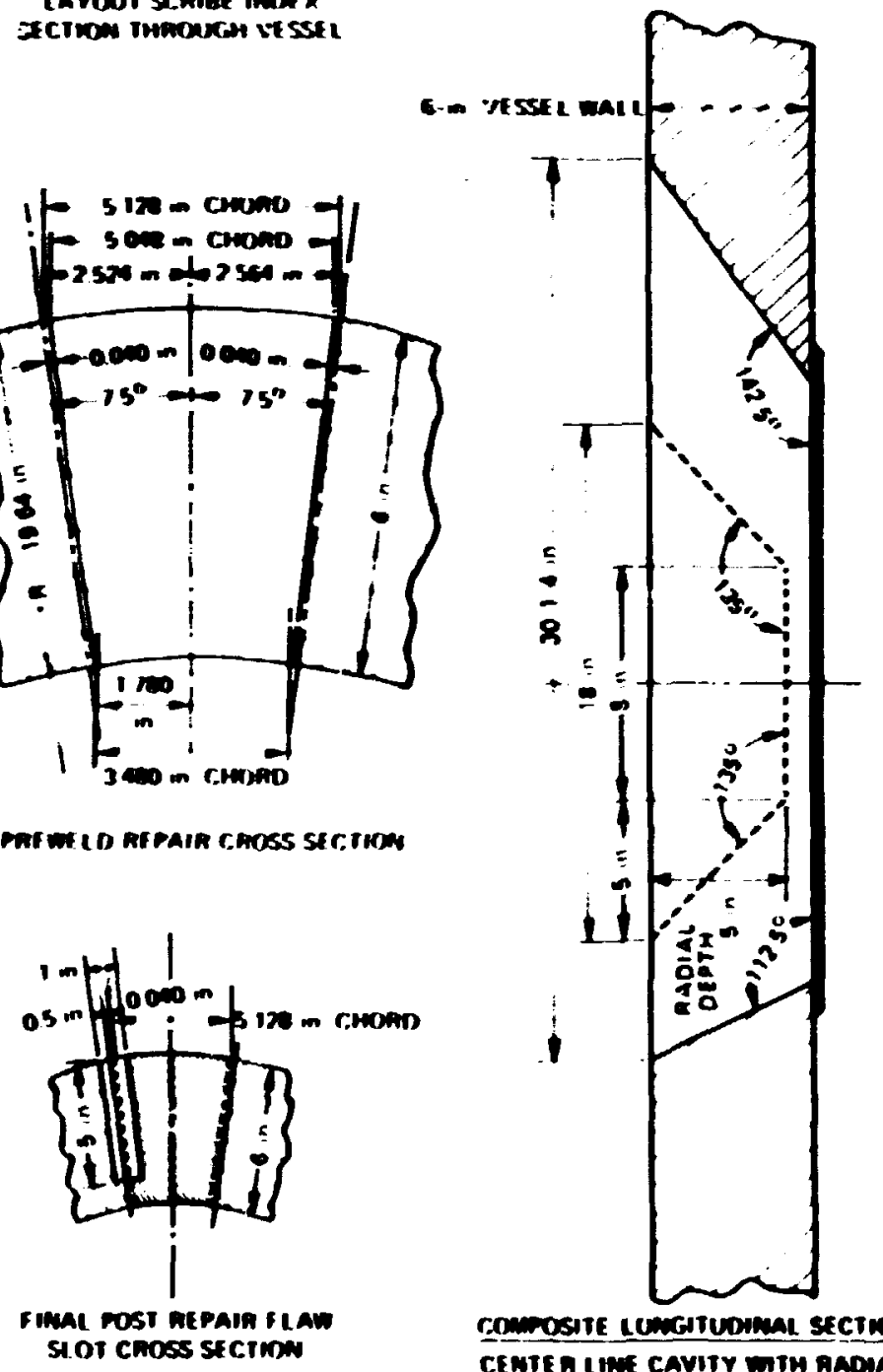

commosite congtudumal section

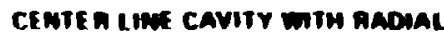
Mant SNOE FLAM CUTOUT SLOT SURE RMMiNOSE D

Fig. 3.10. Intermediate test vessel V-7B repair cavity and flaw preparation detalls $(1 \mathrm{in} .=25.4 \mathrm{~m})$. 
Fig. 3.11. Crose section of the V-7B almulueton repalr weld, V-8 prolongation. 
The repair welds were located along edge portions of the manufacturer's sen weld with the prolongation weld centered within the cylinder and the vessel reld centered about the aidpoint of the vessel's cylindrical portion. The proloagat ion repair was located $180^{\circ}$ from the previously described V-7B simulation repair (Fig. 2.5). Vessel V-8 and prolongation V-8 simulation repair welds had nearly identical dimensions as shown in Fig. 3.12. Unlike previous air-arc gouged and ground cavities, the V-8 and V-8 simulation cavities were machined by Union Carbide shops at Dok Ridge, Tennessee (see Figs. 3.13 and 3.14), in order to permit precision indexing into the original vessel seam-weld radial side planes and to pereit uniforn depth. The bolted head end of the vessel and the shell end of the proloagation were orifited dowaward during welding. Helding progression was in vertical passes. A cross section of the V-8 simulation weld is shom in Fig. 3.15 .

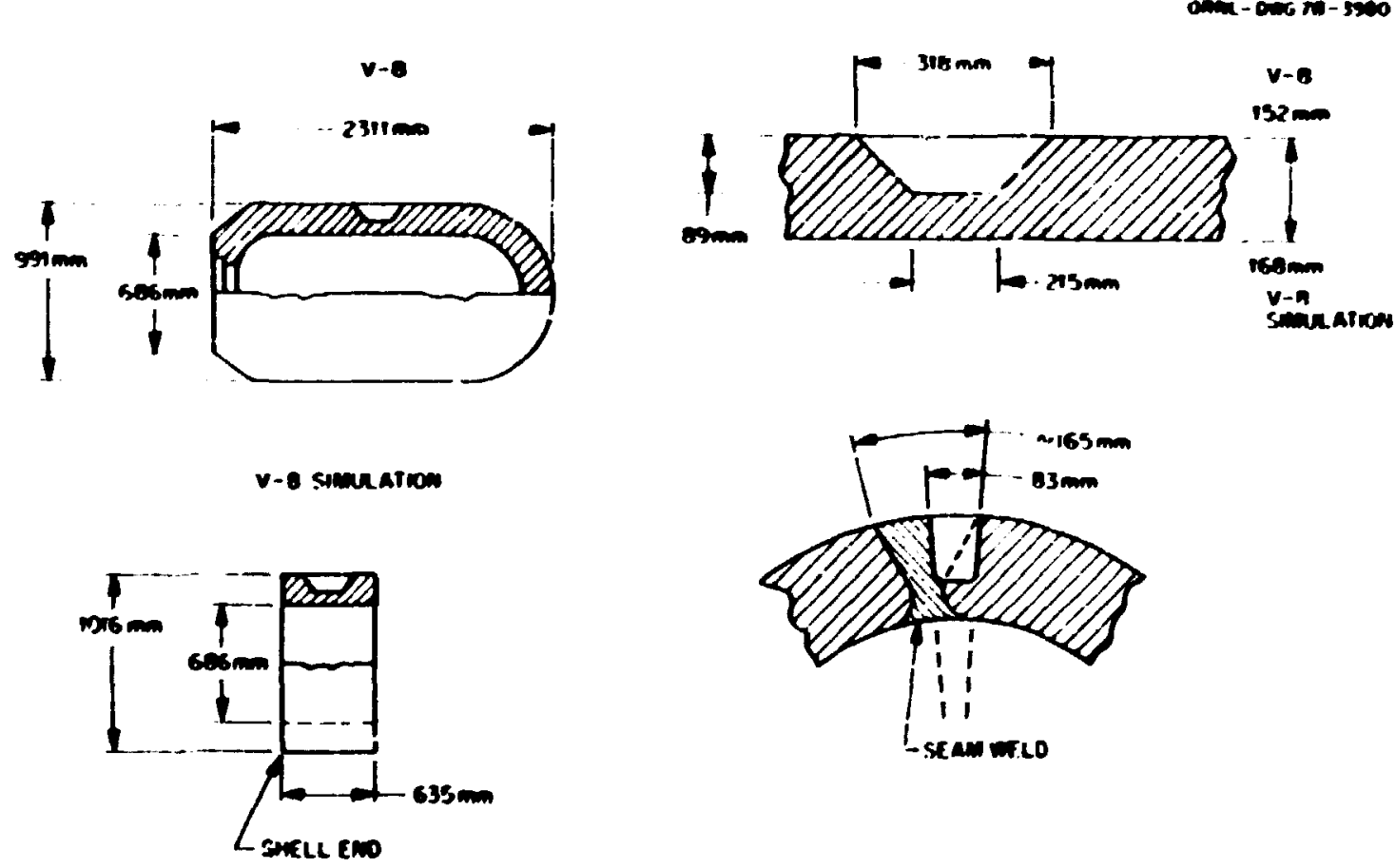

P18. 3.12. Veseal $V-8$ and V-8 simulation repair weld cavity, V-8 veseel and $v-8$ prolongation $(1=0.0394 \mathrm{in}$.). 
OANL motosin:-

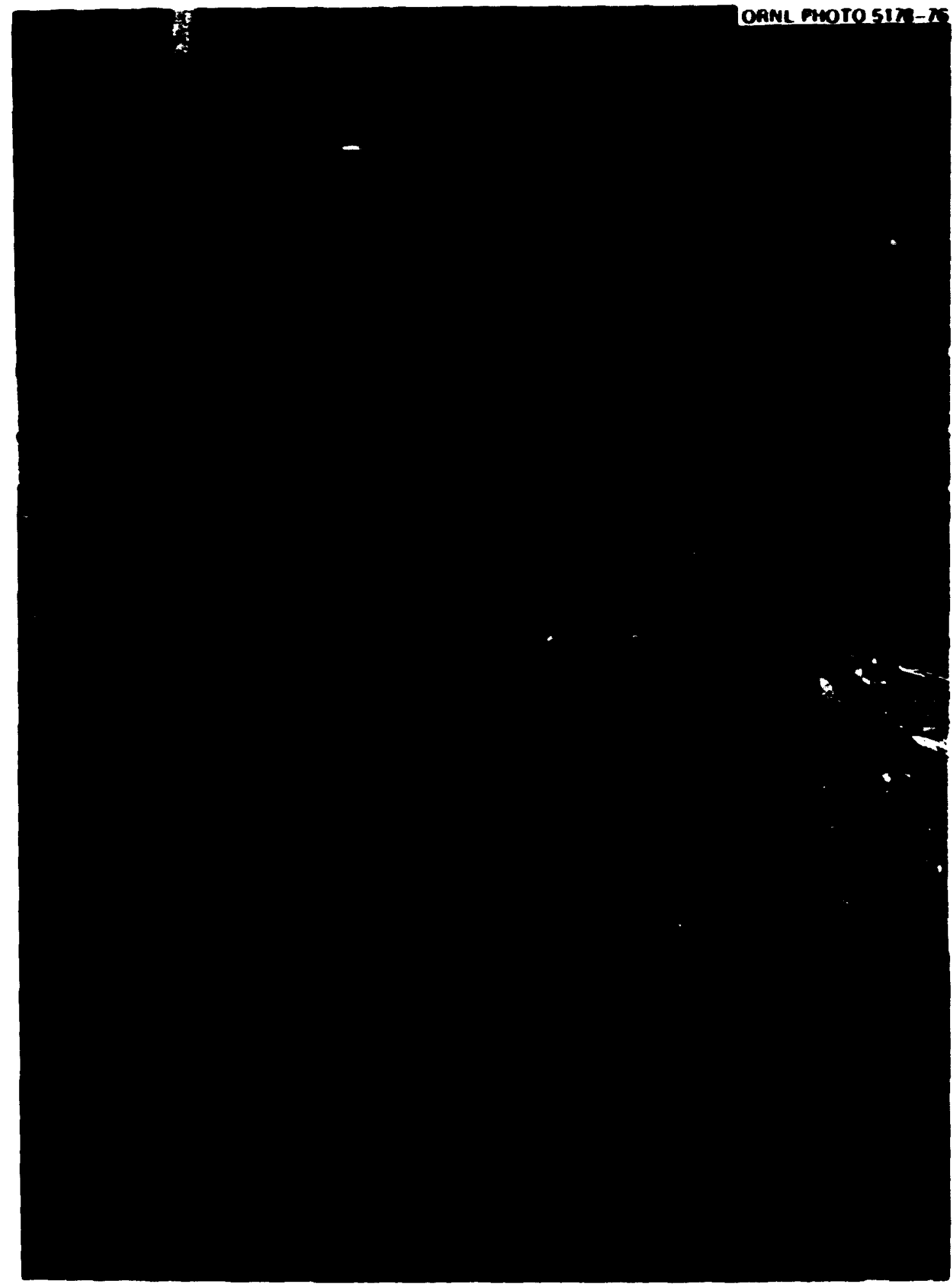

P18. 3.13. Interned iate test vescel V-8 weld repair cavity achining operations. 


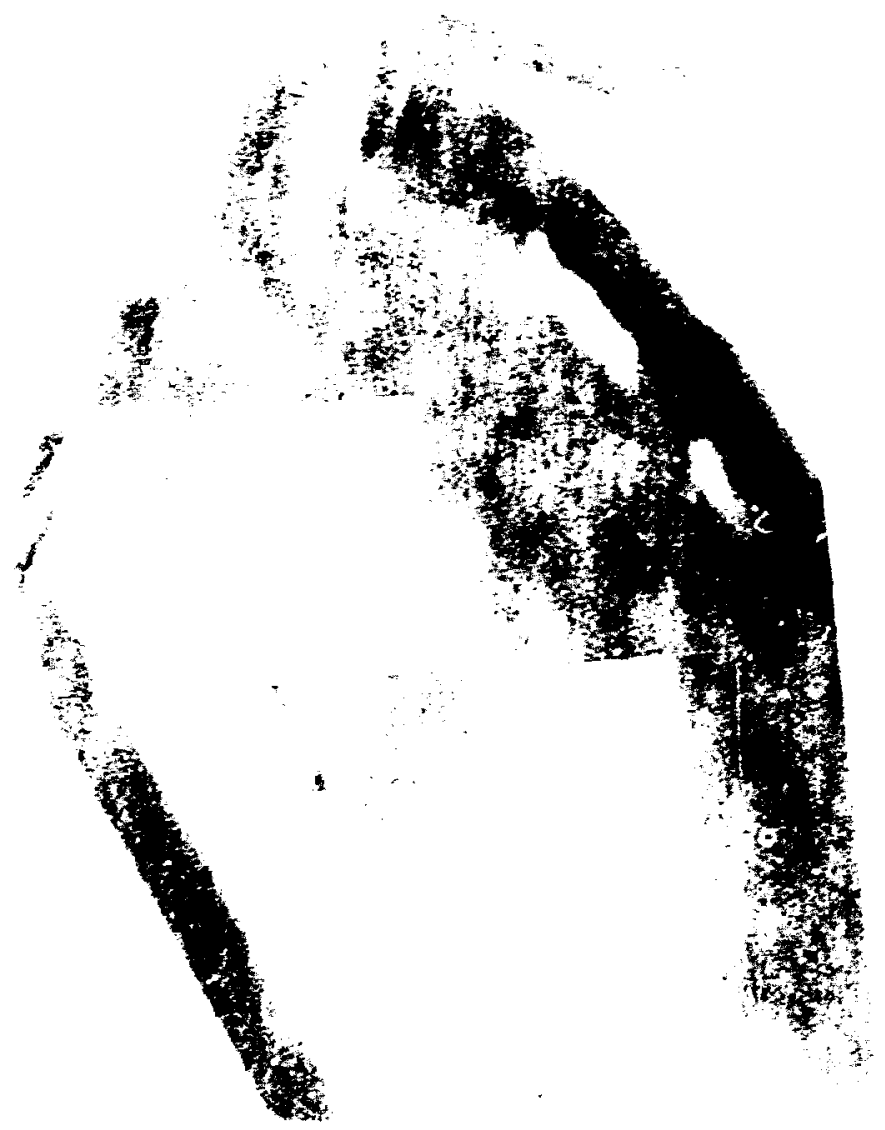




\section{(1)}

(1)

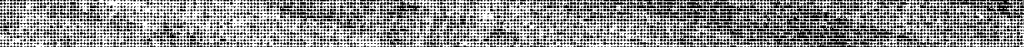

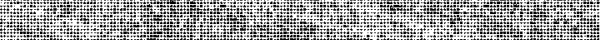

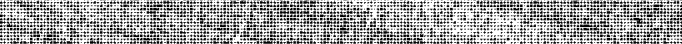

T.

(1)

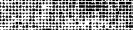

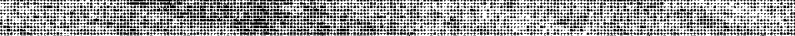




\section{References}

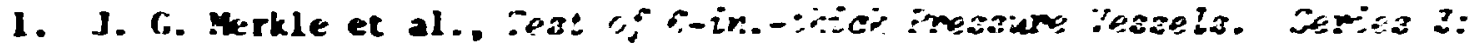
Intermediate geat feasel $\%$, orevl/AurEc-l (August 1976).

2. American Society of Mechanical Engineers, Section $X ?$, Thles for Ir:-

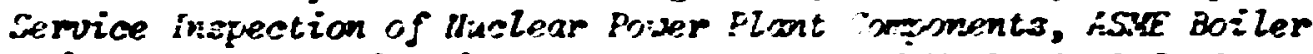
and Eressure jessel rode, American Society of techanical Engineers, New York, July 1975.

3. K. D. Coins and D. L. But ler, Meld Repair of Internediate Test Vessel

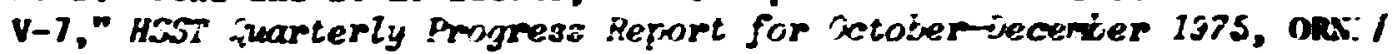
NUnEC/TI-3, PP. 43-56, (April 1976).

4. H. D. Colns and D. L. Butler, Leld Repair of Heavj-Section Steel Technology Progran :essel $7-7$, EPRI KP-179 (August 1976).

5. H. J. Stelzan and D. A. Canonico, "Characterization of the Weld Hetal in Vessel $v-7$ Weld Repair," Huxy Section Steel Technology Pragroun Quarterly Progress Report :or January-Harch 1376, Oeul/NurEc/Tt-28, PP. 36-43 (July 1976).

6. R. H. Bryan et al., Tcst of 6-in.-thick Pressure Vessel. Series 3: Intermediate Test Vessel $V-i A$ inder Sustained Loading, onu/MuRsG-9 (JuIy 1977).

7. P. P. Holz and S. W. Wismer, Half-Bead (Temper) Refair Welding for Heavy-Section Steel Technology Pragram Vessels, oun/Munsc/m-177 (to be publishud). 


\section{$\therefore$ SESID:AL STRESS MEASLRFMETT METHOS}

This chapter describes the two techniques that were used to measure residual stresses in the vicinity of the $V-i n, V-i a$, and $t-8$ repair welis and their respective sinulations in prolongations. The first technique chat will be described involves direct strain gage readings before and after the weld repair. The second cechnique that wi:l be descrited is known as the hole-drilling sechnique. In order co measure residual stresses at through-thickness locations, it was necessary to section the specinen. This of course can affect subsequent strain readings, and thus a wethod favolving strain gage data taken durfing sectioning was used to estinate the residual stresses that were relieved during the sectioning process. The nethod used to account for the relaxacion of residwal stresses raused by sectioning is discussed in Chapter 5.

\section{Direct Strain Gase Nethod}

The direct strain gage method involved locating gages on the vessels and prolongaticas after the cavitles were machined into the specinens but before welding began. The gages were generally Ailce:h SC 425 weldable gages, except for 9 Ailtech SC 125 weldable gages that were placed on the prolongation used for the V-7A simulation repair weld. The SC 425 gages are stable at temperatures below $482^{\circ} \mathrm{C}\left(900^{\circ} \mathrm{F}\right)$ while the SG 125 gages are stable below $316^{\circ} \mathrm{C}\left(500^{\circ} \mathrm{F}\right)$. Both have gage lengchs of approximately 25 m (1.0 in.). For all of the V-7B, V-7B simulation, $V-8$, and $V-8$ simulation strain gage sites and for wost of the $V-7 A$ and $V-7 A$ sfimlation strain gage sites, the gages were configured as $T$ 's, and the residual stresses were calculated from the following equations:

$$
\sigma_{a}=\frac{E}{1-v^{2}}\left(\varepsilon_{a}+v c_{c}\right) .
$$

and

$$
\sigma_{c}=\frac{E}{1-v^{2}}\left(\varepsilon_{c}+v \varepsilon_{a}\right) \text {. }
$$


where the subscripts $a$ and $c$ denote the axial and circumferential directlons, respect tvely. Young's mofulus, E, was taken as $200,000 \mathrm{MPa}(29 \times$ $10^{6} \mathrm{psi}$ ) and Polsson's ratio was taken as 0.29 . For single isolated 8-ges, the equation used to calculate stresses was

$$
\sigma=E \varepsilon_{0} \text {. }
$$

The gages were zeroed at room temperature. Thermocouples were located around the weld cavity lgenerally at weldable strain gages sites 38 ( $1.5 \mathrm{in.})$ from the cavity boundary]. The thermocouples were monitored to ensure that the temperiture of the vessels and prolongations did not exceed $316^{\circ} \mathrm{C}\left(600^{\circ} \mathrm{F}\right)$ during the welding operation. If che temperatures Indicated by the thermocouples showed a tendency to rtse above their nominal $260^{\circ} \mathrm{C}\left(500^{\circ} \mathrm{F}\right)$ value, then the rate of depositing veld wetal was decreased. The strain data were exanined during hold periods at constant cemperatures to cierermine if drift was occurring. There was no indication of any strain gage drift for the reported data. Upon completion of the weld repait and the seturn of the specimen to room temperature, a final strain gage reading was made. It was this $f$ inal value of strain that was used to calculate a change in stress resulting from the weld repair.

\section{Hole-Drilling Method}

A commonly used method for measuring residual stresses involves the attachment of a strain rosette to a surface where stresses are to be measured.' The rosette gages are initially zeroed and a small hole [e.g., 1.59 (1/16 in.) diam] is drilled into the specimen at the center of the rosette patcern. The radial distance from the hole cencerline to the gage midooints for the rosettes used here was $2.54 m(0.10 \mathrm{in.})$. The depth of the hole is of the order of the hole diameter. The resoval of aterial, which presumably was stressed, results in relaxation strains being indicated by the rosette gages. By means of calibration coefficients, It is possible to calculate the state of stress that existed at the hole site prior to drilling. Figure 4.1 is a photograph of one of the two sections of the V-7A simulation weld repair which were used for throughthickness measurements. It has four rosettes and associated tabs attached 


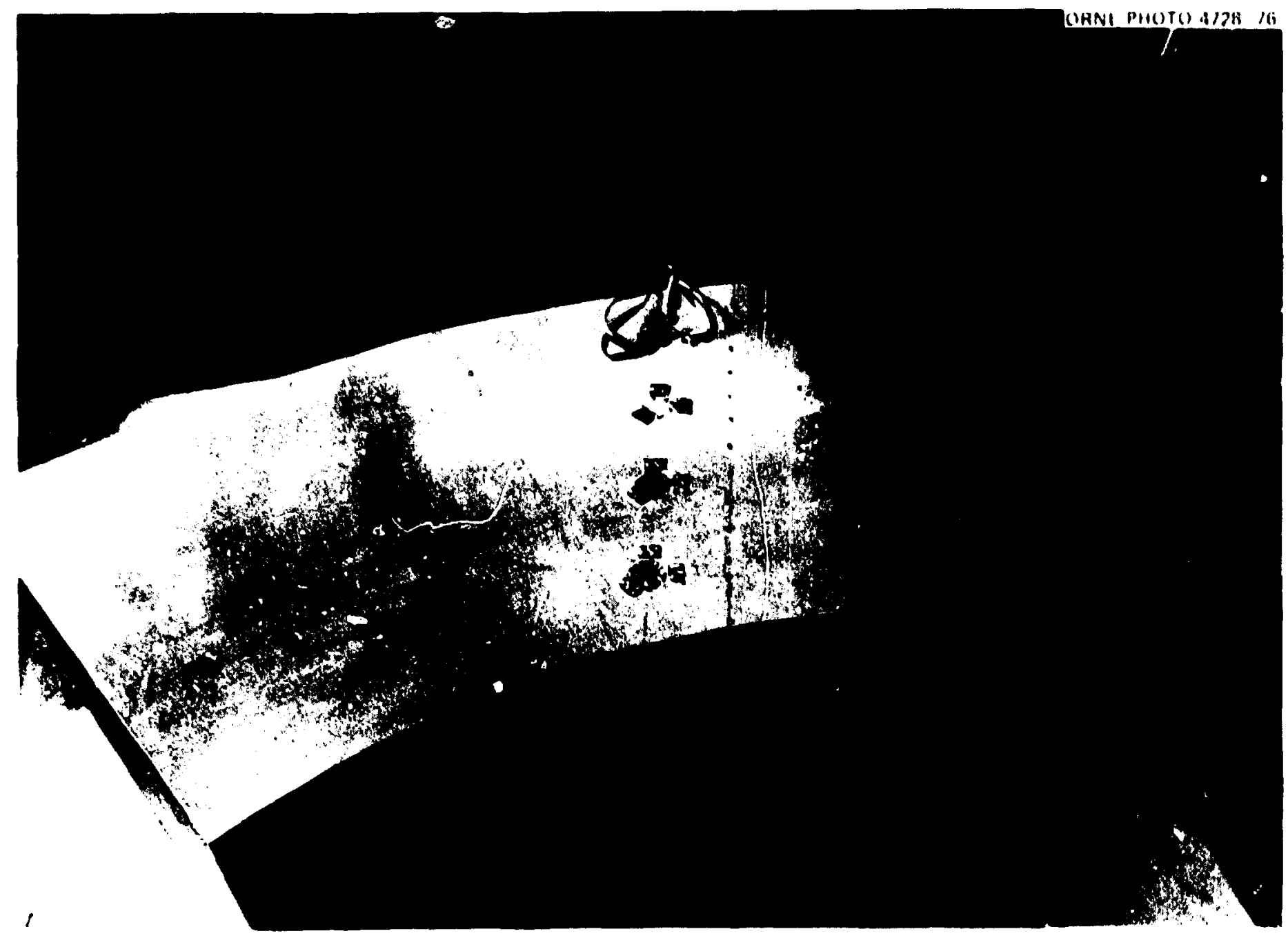

F1g. 4.1. A section of the V-7A simulation repalr weid that has strain gages in place for subsequent hole-drilling measuruments. The holes in the specimen are from previous measurements $(V-7 \lambda$, Plece $c$, Fip. 5.1). 
In weld metal. The boles to the right of the rosettes, (i.c.., in the base metal and the heat-affected zone) were drflled during prior measurements. The gages for those ceasurements had been removed, and a mild etch had been used to enhance the weld-metal/base-petal boundary.

A substantial segment of the hole-drilling data for the $v-7 A$ simulacion veld was generated at WROC. These data were obtained using Micromeasurement 062RE gages (specially designed gages for the hole-drilling method) and a drilling technique using a streas of air containing fine abrasive particles which chip away the workplece material. Reference 2 contains a discussion of the approach used at URDC. The remainder of the hole-drilling data was taken at ORNL and fnvolved the use of Micromeasurewenc 062RF gages and a conventional hand-held drill. Figure 4.2 illustrates how the drill is used with a sighting and stabilizing plat form which can be firmly attached to the specimen with an adhesive. Figure 4.3 shows the stabilizing platform and eyepiece that were used to align and measure the actual drilled hole dianecer.

The ORNL data were reduced as prescribed in Ref. 3 with one exception. It had been reported ${ }^{2}$ that mechanical drills cended to induce a fictitious apparent strain. Extensive hole drilling on stress-free* bars of $A 533$ steel and on stress-free weld metal taken from the V-8 simulation repair at ORN confirmed these observations. (See discussion in Appendix B.) It was noted, however, that the fictitious apparent strain applied fairly uniformly to each of the three gages in the rosette when the wechanical drill was usect. It wes therefore decided to compensate for the average apparent strafn $(-78 \mu \varepsilon)$ induced in the stress-free bars and samples by adding an equivalent awount with the opposite sign to each measurement made on the vessels and prolongations.

The relationshipe used by ORW to calculate the principal stresses from the strain changes measured as a result of hole drilling and adjusted to elininate the spurious drilling effects are given by ${ }^{3}$

$$
\sigma_{X}=\frac{(A+B \cos 2 B) E_{2}}{4 A B} \frac{-(A-B \cos 2 B) E_{1}}{\cos 2 \beta}
$$

The bars were heated to $621^{\circ} \mathrm{C}\left(1150^{\circ} \mathrm{F}\right)$ and held at temperature for $72 \mathrm{hr}$ and then furnace cooled over a 24-hr period. 


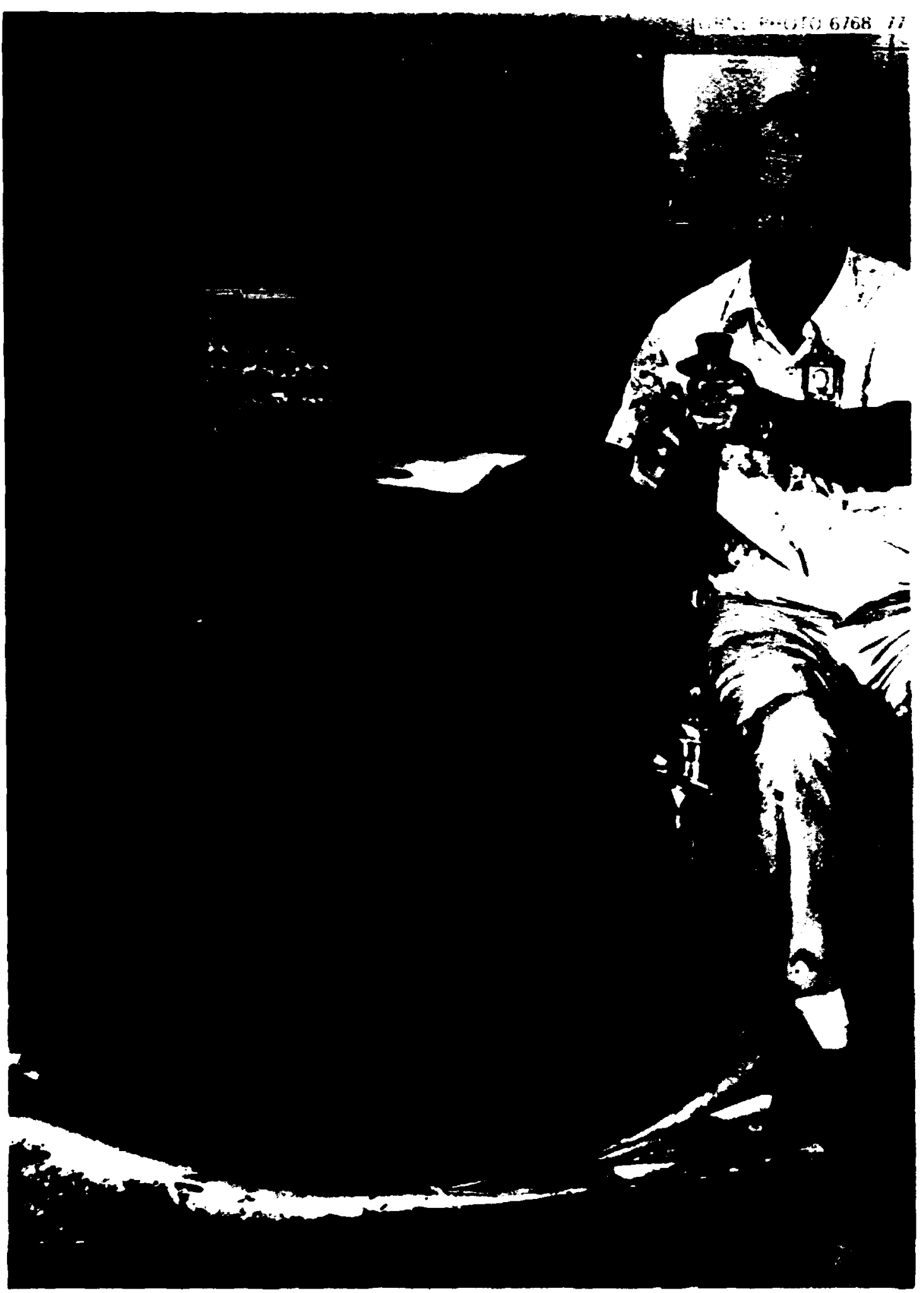

Fig. 4.2. Mechanical drill and stabilizing platform used for holedrilling measurements at ORNL (V-7B, Piece B, Fig. 5.1). 


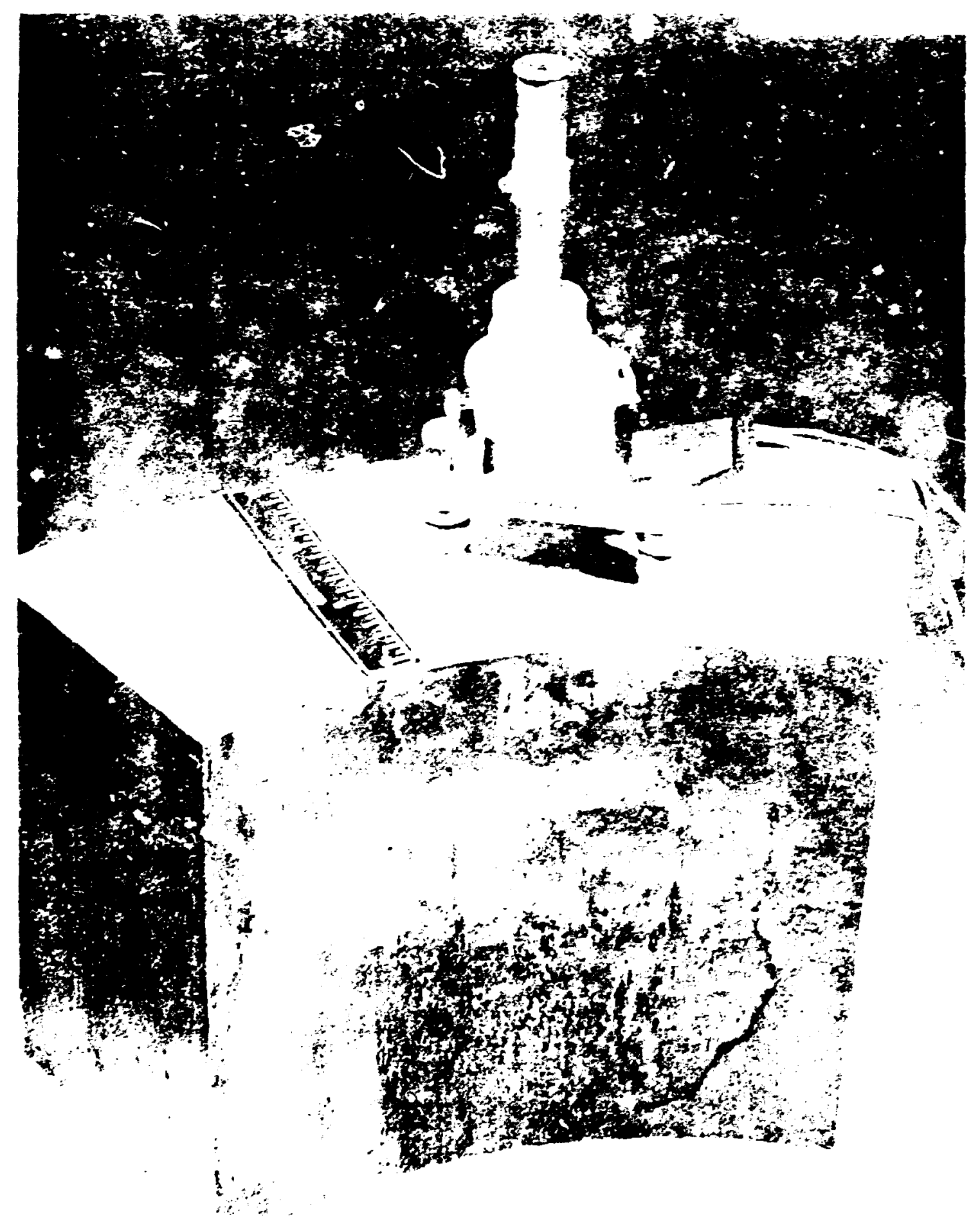




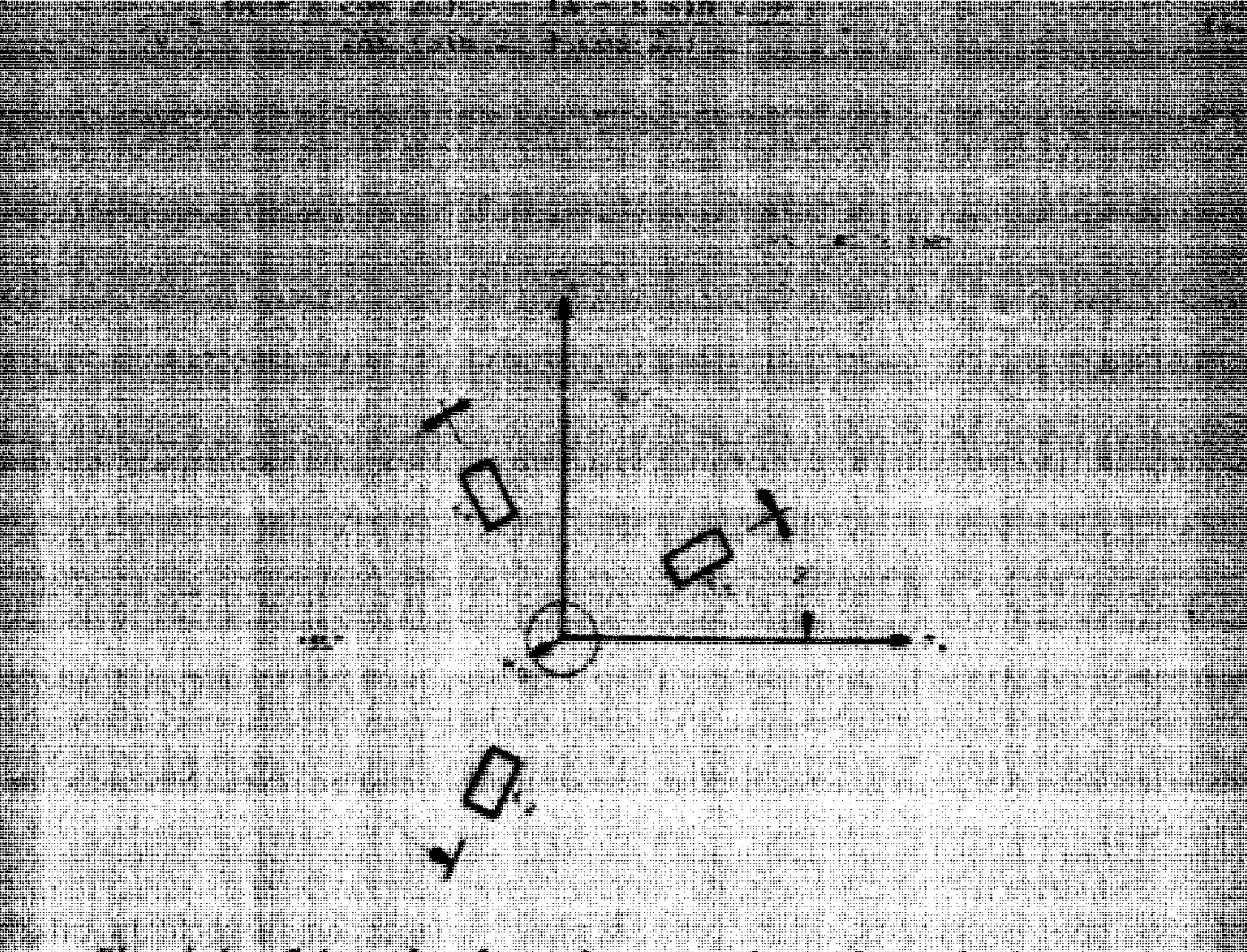

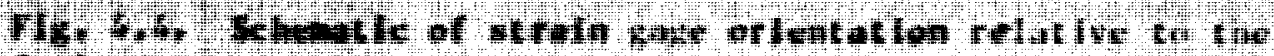

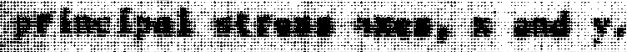

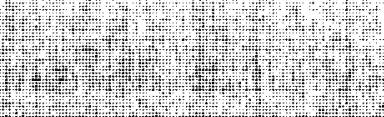

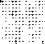




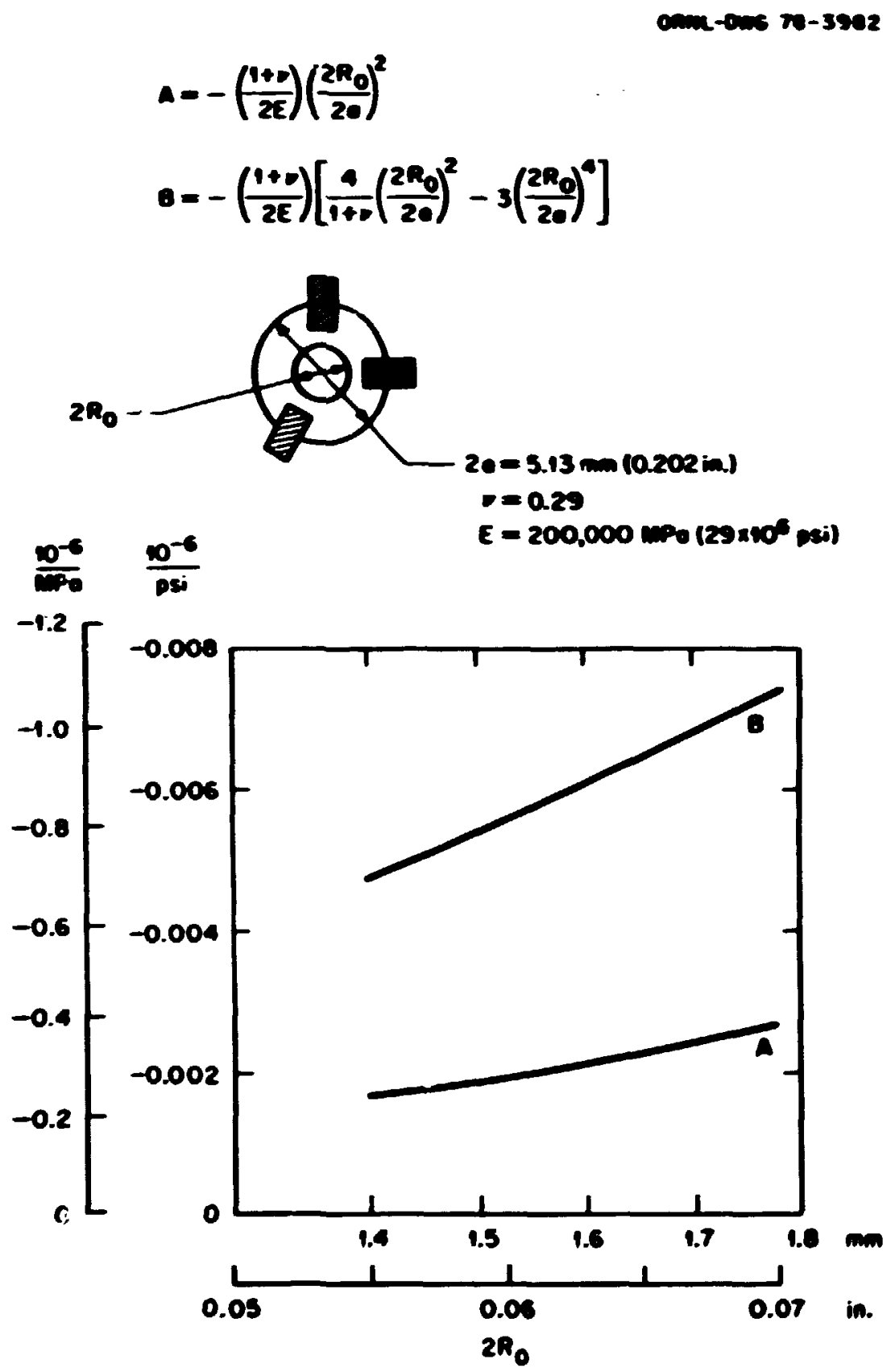

P1g. 4.5. Coefficients used to deteratine stresses from hole-drilling mesurcments (Type 0.062 Re gage on steel). 
A scheatic of the drills (double-fluted end alls which vere specially ground) used for the Oavj. hole-drilling measureneats is shown in Fig. 4.6. Each drill we used for not wre than three holes.

A study of the hole-drilling method is reporzed in Refs. 4 to 6. Peference 5 concludes that overall measurement accuracy of the holedrilling necbod used by the author (air abrasive) $18 \pm 87$ except when the residual streses are greater than $50 z$ of jield. Above that level, ertors increase due to gielding around the hole; and depeadine on spocific conditions, the ertor could increase by up to \pm 168 for a residual stress level near yield. Sonewhat lower accuracy would be expect for the mechanical drilling approach.

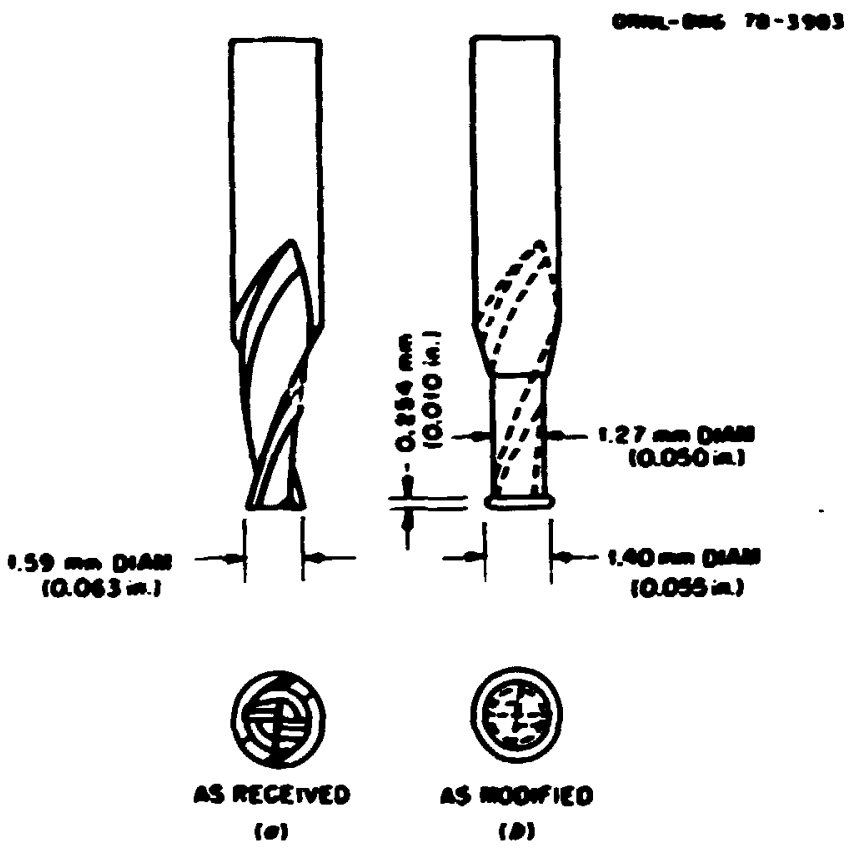

Fig. 4.6. Double-fluted end aill as modified for hole-drilling operation.

\section{References}

1. N. J. Readler and I. Vigness, "Hole-Drilling Strain-Gaze Method of Measur ing Restdual stresses," Exp. Mech. 6, 577-86 (Decenber 1966).

2. A. J. Bush and P. J. Kromer, "Simplification of the Hol z-Drilling Hethod of Residual Stress Measurement," ISA Trans. 12(3), 249-59 (1973). 


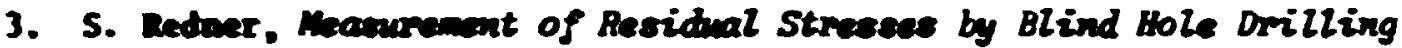
Method, Dulletin IDG-5. Photoelastic, Inc. (May 1971).

4. E. M. Deaney and E. Proctor, A Critioal Evaluation of the Contre bole

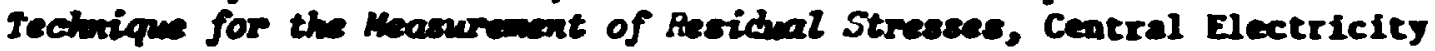
Generatiog Doard, Desearch Departuent, Derkeley buelear Laboratories, Dis/ri2492 (lovenber 1972).

5. E. M. Desocy, Acourate Mearurament of Residual Strese on Ary Stesl Using the Centre bole Mrthod, Central Electricity Cenerating Board, Research Departuneat, Rerkeley Ahclear Laboratories, RD/B/m3568 (Decenber 1975).

6. U. P. Reen and E. H. Neaney, inatructions for Using the Aim-Abrorive Centre bole Equipment to Mr.jewe Arsidwal Strese, Central Electricity Cenerating Doard, Research bepartweat, Derkeley Reclent Laboratories. RD/B/M3700 (June 1976). 


\section{STRESS RELAXITION RESULTING FROA SECTLONING}

In order to obtain through-thickness residual stress measurenents, it wa neceseary to section each of the two prolongations. Figure 5.1 shows the sectioaing plans for both the V-9 and V-8 prolongations. The pieces used for experinental measurement of residual stresses or eaterial properties are labeled with letters, and the cuts in the order that they were
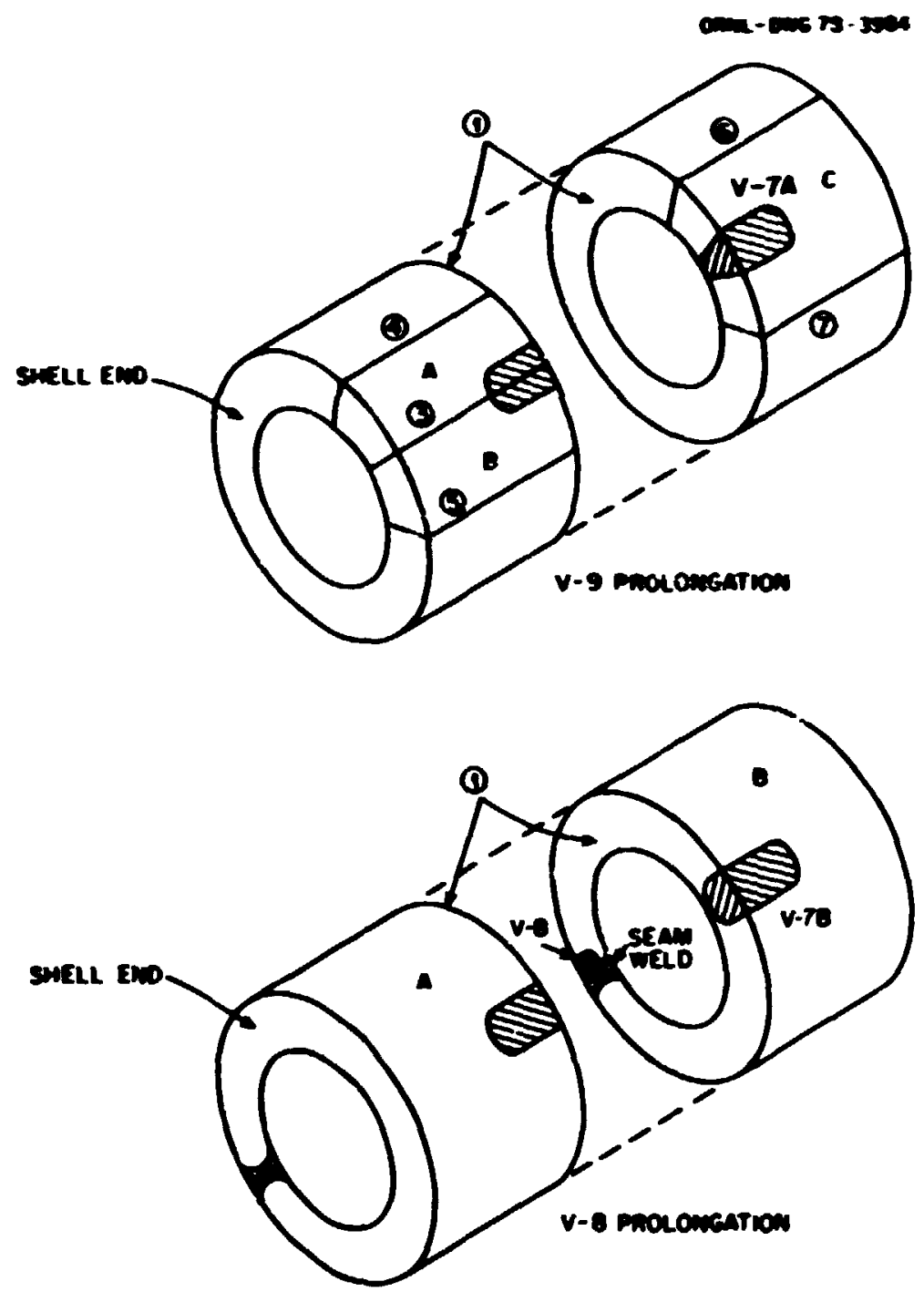

Fig. 5.1. Schenatic of the two prolongations used for the staulation (qualification) repair welds. Nubers indicate the order that the veseels were cut to allow through-thicknese residwal seress masurenents. Cut 2 for each prolongation rewoved the ends of the reanining crose bracing. 
ade are labeled with nubbers. The sectioning of the prolongations would, of course, relax and redistribute the residual stresses. This chaptar describes the methods used to deternine a correction so that the throughthickness residual stresses in the unsectioned prolongations could be estinated. The estinate is based on subeequent hole-drilling measurewents ade on the sectioned pleces and the changes in surface strains that were neasured durfos the saring operation. All of the through-thickness hole-dr:lling data are coatalned in the appendices. Chapter 6 of this report is a samy of the wost significant findings, and all of the through-thickneas measurewents contained in that chapter have a correction for sectioning taken directly fron either Fis. 5.5, 5.9, or 5.10 (depending on the particular weld repair and orientation of the stresses under consideration). In general, the correction for sectioning consisted of superposing a tensile stress (on the order of one-fifth to one-third of the weld netal or base netal yield stress) on the hole-drilling neasurenent. The subsequent two sections describe the corrections that were found for the V-8 and the V-7A simulation repair welds, respectively.

\section{V-8 Sibulation Repair Held Sectioning Correction}

Figure 5.2 shows the V-8 prolongation with the V-7B and V-8 simulated repair welds being sawed in half. The bundle of wres in the figure connect strain gages on the prolongation to strain gage readout equipent. Since circunferential stress vartations through the thickness of the cylinder in the V-8 repair weld were the principal concern for a subsequent HSST vessel test, the single saw cut bisecting the prolongation and shown in Figs. 2.5, 5.1, and 5.2 was all that was ade on the V-8 prolongation prior to the hole-drilling weasurenents.

Twenty equally spaced alternating axial and circuferential strain gages were located on arcs about piece B, parallel to the cut and near the V-8 simiation repair wid. The outside surface gages were located 6 wa ( $0.25 \mathrm{in}$.) from the cut line and the inside gages wre located 13 - $(0.50 \mathrm{in}$.) fron the cut 1ine. Ten additional strain gages were sinilarly located near the V-7B simulated repair weld, but the V-7B data were subequently not considered useful because of the nonsymetry of the repair 
F18. 5.2. Sawing the V-8 prolongation into two equal pleces for the purpose of making through-thlcknues residual otress meseurements. 
weld with respect to the cut section. The sitrain eages used were Hicroneasurenent EA-06-250SG-120. The changes in straias as a result of the bisectiag sw cut are given in Table 5.1; the cylindrical coordinate systen is defined in Fig. S.3. The streases listed in Table S.1 were calculaced using Eqs. (4.1) and (4.2).

The axial stresses listed in Table 5.1 are plotted vith their signs reversed in Fig. 5.4. The values in Fis. 5.4 give an indication of the axinl residusl stress existing alous the surfaces of the V-8 prolongation at the center of and on the surface near the $v-8$ simulated weld repair prior to any sectioning. There would probably be considerable averaging of chese stresses as the relaxation of stress at any point would influence every otber point in the sectioned prolongatien. The circunfereatial stresses from Table 5.1 wich their signs revereed are plocted in Fig. S.5. The relaxation of the circunferential stresses shown in Fig. 5.5 does not have a straightforvard physical interpretation lite that of the axial

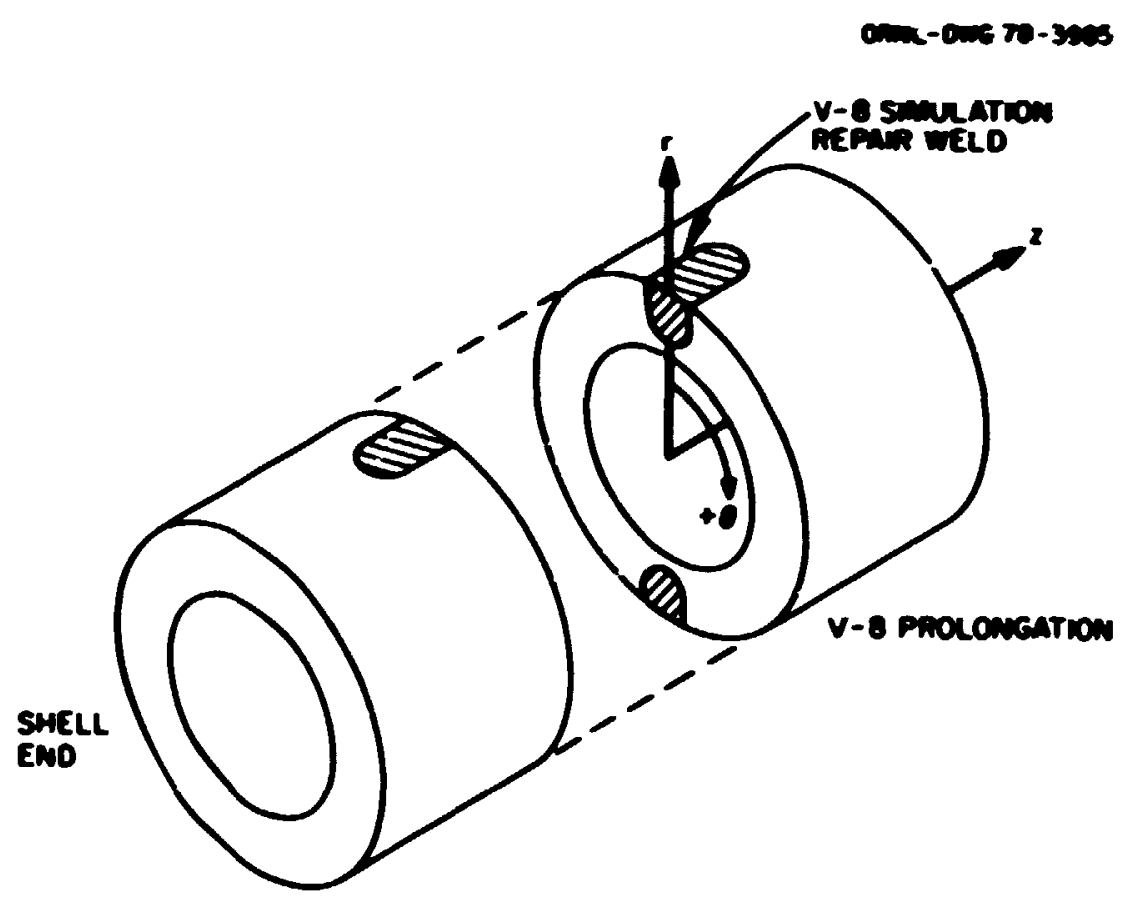

Fig. S.3. Cylindrical coordinate system used to define the location of strain gages listed in Table 5.1 which were monitored during the sectioning of the V-8 prolongation. 
Table 3.1. Measured strain changes thac resulted from the sectioning of the V-8 prolongation

\begin{tabular}{|c|c|c|c|c|c|c|c|}
\hline \multirow{2}{*}{$\begin{array}{l}\text { Gage } \\
\text { to. }\end{array}$} & \multicolumn{3}{|c|}{ Coordiances $a$} & \multirow{2}{*}{$\begin{array}{c}\text { Fage } \\
\text { oricatatioa }\end{array}$} & \multirow{2}{*}{$\Delta x$} & \multirow{2}{*}{ 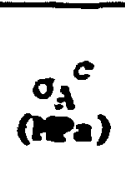 } & \multirow{2}{*}{$\underset{\left(C^{2}\right)}{\sigma_{c}^{c}}$} \\
\hline & $(\mathbf{m})$ & $\left(\begin{array}{c}0 \\
(\operatorname{ses})\end{array}\right.$ & (2) & & & & \\
\hline
\end{tabular}

\section{V-8 repair weld}

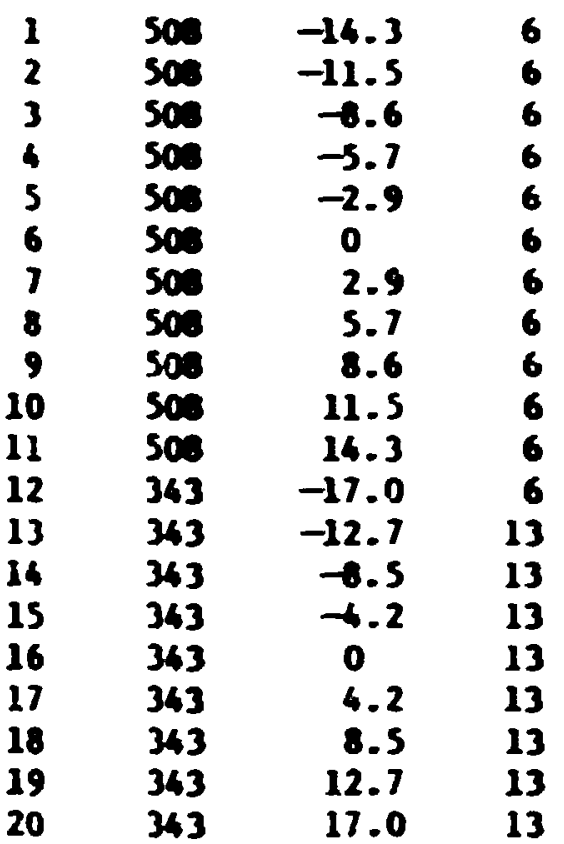

A

c

A

C

a

C

a

c

a

C

$\hat{c}$

C

A

C

C

A

C

A

C

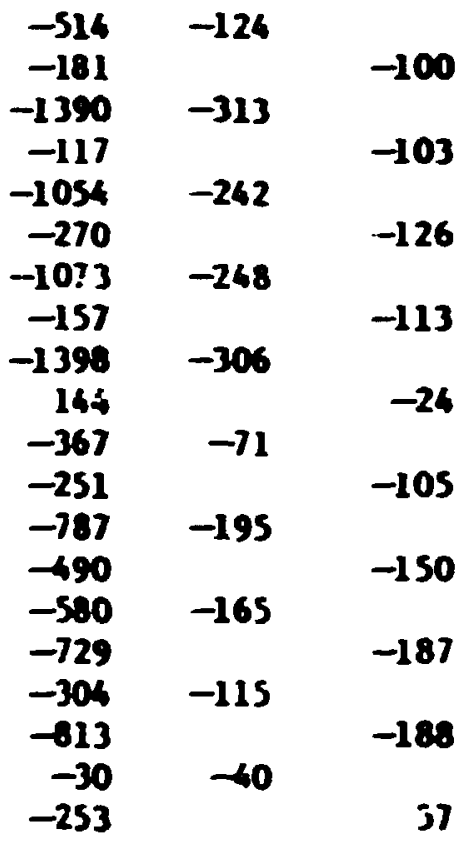

V-18 repair weld

$\begin{array}{lllr}21 & 363 & 192.7 & 25 \\ 22 & 343 & 197.0 & 25 \\ 23 & 343 & 184.2 & 25 \\ 24 & 343 & 188.5 & 25 \\ 25 & 343 & 175.8 & -25 \\ 26 & 343 & 180.0 & 25 \\ 27 & 343 & 167.3 & -25 \\ 28 & 343 & 171.6 & -25 \\ 29 & 343 & 180.0 & -25 \\ 30 & 343 & 163.0 & -25\end{array}$

c

$-605 \quad-131$

$-197$

$-906 \quad-216$ $-81$

A

225

$-944 \quad-324$

C

495

$-275$ 1

$-1545$

$-2180$

asee Fis. \$.3 for coordinate systen definition.

$b_{A}$ represenes exial and C circuiferential.

'Sereas calculated according to Eqs. 4.1 and 4.2 where the Polsson component was taken as an overage. of edfacent gages when possible. 


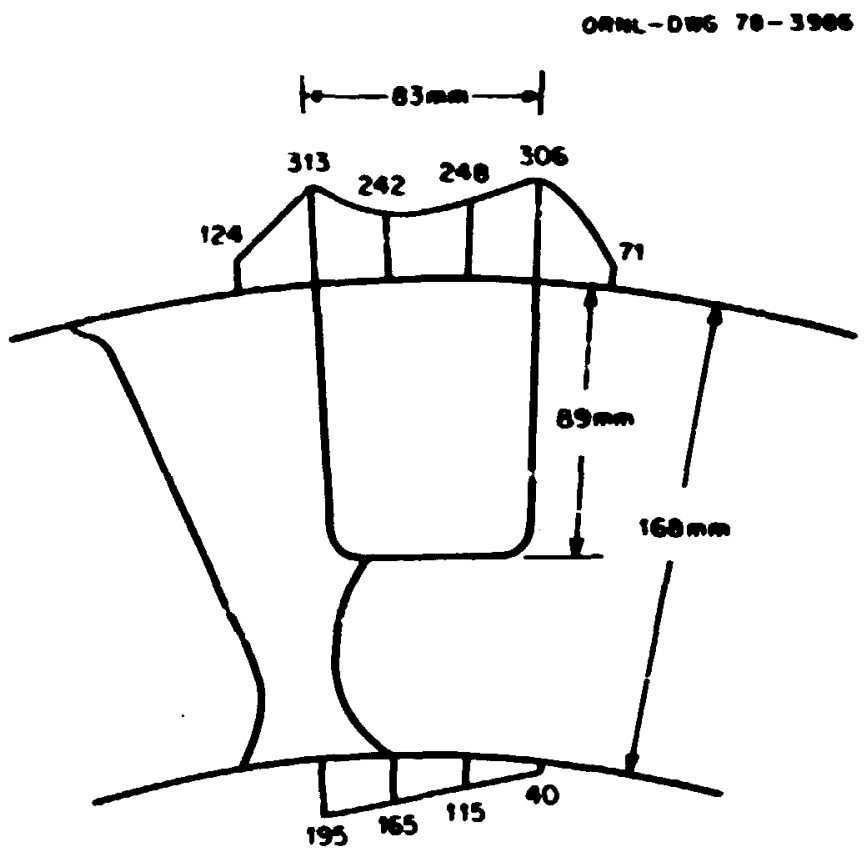

Fig. 5.4. Axial stresses (APa) calculated from the strain relaxation caused by a single bisecting saw cut of the V-8 simulated repair weld ( $1 \mathrm{MPa}=145$ psi; 1 m $=0.0394$ in.).

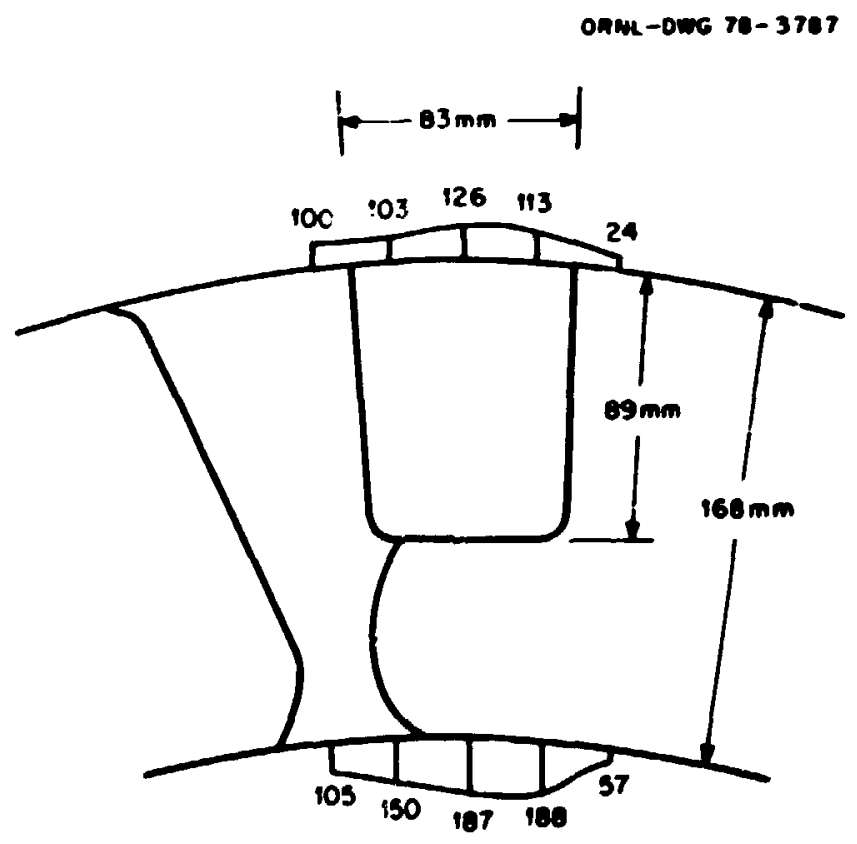

Fig. 5.5. Circumferential stresses (MPa) calculated from the strain relaxation caused by a single bisecting saw cut of the V-B simulated repair weld ( $1 \mathrm{MPa}=145 \mathrm{psi}$; $1 \mathrm{man}=0.0394 \mathrm{ln}$.). 
stresses. The circunferential stresses indicate stress changes due to sectioning but not total residual stresses. However, they are useful for adfusiting subsequent through-thickness residual atreas measuremeats so that the stresses in the uncut specinen can be estinated. Fifty-two through-thickness measurements were subsequently ade on cut face B-1 (see Fig. 5.1) of the V-8 prolongation. For 31 of those neasurements (reported in Chapter 6), the calculated through-thickness circunferential stresses were adjusted by adding a value deternined fron a linear interpolation of the two surface circunfereailal stress changes (shown in Fig. 5.5) due to sectioning that were measured along the radial line nearest to the neasurenent point.

\section{V-7A Simulation Repair Weld Sectioning Correction}

The V-7A simulation repair weld was also used for through-thickness residual stress measurements and therefore the V-9 prolongation was also sectioned. Since the V-7A simulated weld was to be used to obtain both the axial and circunferential residual stress distributions, additional cuts on the V-7A prolongation were necessary as shown in Fig. 5.1. Three swall sections were thus cut from the V-9 prolongation. One of the sections (section C) is shown in rigs. 4.1 and 4.3. Another section (section A) is shown schematically in Fig. 5.6. The third section (section B) was used only for material property weasurements. Ten Micromeasurement EA06-062RG-120 strain rosettes were attached to section $A$ at the locations Indicated in Fig. 5.6. These rosettes were monitored during the sectioning of the V-9 prolongation and the resulting strain changes were used to calculate stresses. The gages were zeroed prior to the first saw cut.

Table 5.2 11sts the indicated strain fron those rosettes after cut 1 was complete, after cut 3 was complete, after the saw had penetrated 76 mam (3.0 in.) into the wall during cut 4, and after cut 4 was completed. One of the strain gage junction boxes falled prior to completion of the fourth cut, and the corresponding data were lost. There was only sight additonal relaxation (see Table, .2 ) as a result of the fourth cut, and therefore the strain data taken halfway through cut 4 were considered appropriate for describing the relaxation of the completely sectioned 
Table 5.2. Stratn measurements from rosettes located on plece $\lambda$ of the V-a prolongation during sectloning

\begin{tabular}{|c|c|c|c|c|c|c|c|c|c|c|c|c|c|c|c|}
\hline \multirow{2}{*}{$\begin{array}{l}\text { Cage } \\
\text { No. }\end{array}$} & \multicolumn{3}{|c|}{ Coordinates } & \multicolumn{3}{|c|}{ After cut $1^{b}$} & \multicolumn{3}{|c|}{ After cut $3^{3}$} & \multicolumn{3}{|c|}{$\begin{array}{l}\text { lladeway through } \\
\text { sue it }\end{array}$} & \multicolumn{3}{|c|}{ After sut $b^{\prime \prime}$} \\
\hline & $\underset{(m, m)}{x}$ & $\stackrel{y}{(m m)}$ & $\stackrel{2}{(\operatorname{man})}$ & ${ }^{H} \varepsilon_{a}$ & $\| \varepsilon_{c}$ & $\mu \varepsilon_{b s}$ & $w \varepsilon_{a}$ & HE & wews & $w \varepsilon_{a}$ & Wr. & WE WS & WE & wit & Wit: os \\
\hline $\begin{array}{l}1 \\
2\end{array}$ & $\begin{array}{l}25 \\
31\end{array}$ & $\begin{array}{l}132 \\
152\end{array}$ & $\begin{array}{l}165 \\
165\end{array}$ & $\begin{array}{l}784 \\
713\end{array}$ & $\begin{array}{l}-214 \\
-303\end{array}$ & $\begin{array}{l}386 \\
501\end{array}$ & $\begin{array}{l}878 \\
813\end{array}$ & $\begin{array}{l}-473 \\
-5,2\end{array}$ & $\begin{array}{l}317 \\
490\end{array}$ & $\begin{array}{l}887 \\
824\end{array}$ & $\begin{array}{r}-483 \\
-\ldots 579\end{array}$ & $\begin{array}{l}315 \\
491\end{array}$ & & & \\
\hline 3 & 178 & 152 & 165 & -322 & 3 & $1 \div 0$ & -573 & 34 & 30 & -564 & 37 & 39 & & & \\
\hline 4 & 51 & 51 & 165 & -861 & 293 & -1073 & $-5: 0$ & - & $-\{(1)]$ & -3.1 & -405 & -1038 & -509 & & -1032 \\
\hline 5 & 178 & 51 & 165 & -228 & 201 & 179 & -407 & 711 & 164 & $-1:$ & 708 & 103 & -407 & 718 & 170 \\
\hline 6 & 178 & 25 & 165 & -352 & 222 & 28 & -594 & 101 & $i(07$ & -600 & 100 & 703 & -589 & 106 & 209 \\
\hline 7 & 178 & 105 & 0 & -46 & 42 & -89 & -75 & 153 & 131 & -72 & 142 & 121 & -73 & 15: & 1.04 \\
\hline 8 & 31 & 105 & 0 & 1 & -342 & -165 & -64 & -149 & -1.27 & $\Rightarrow 4$ & -148 & -121 & -50 & -147 & -107 \\
\hline 9 & 178 & 35 & 0 & -197 & 215 & 80 & -125 & -200 & -100 & -126 & -105 & -288 & $-1 \leq 0$ &. .94 & -284 \\
\hline 10 & 51 & 35 & 0 & -402 & -196 & -718 & -543 & 45 & -230 & -543 & 44 & -731 & -516 &, 3 & -724 \\
\hline
\end{tabular}

"Gage locations and the coordinate system are shown in Fig. 3.6.

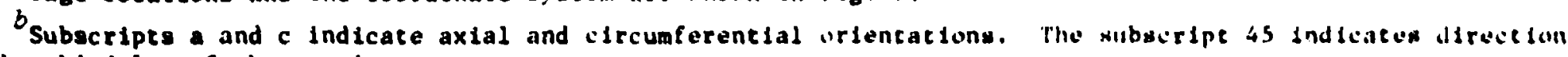
of the third leg of the strain rosette. 
vaist Dato is :3547e?

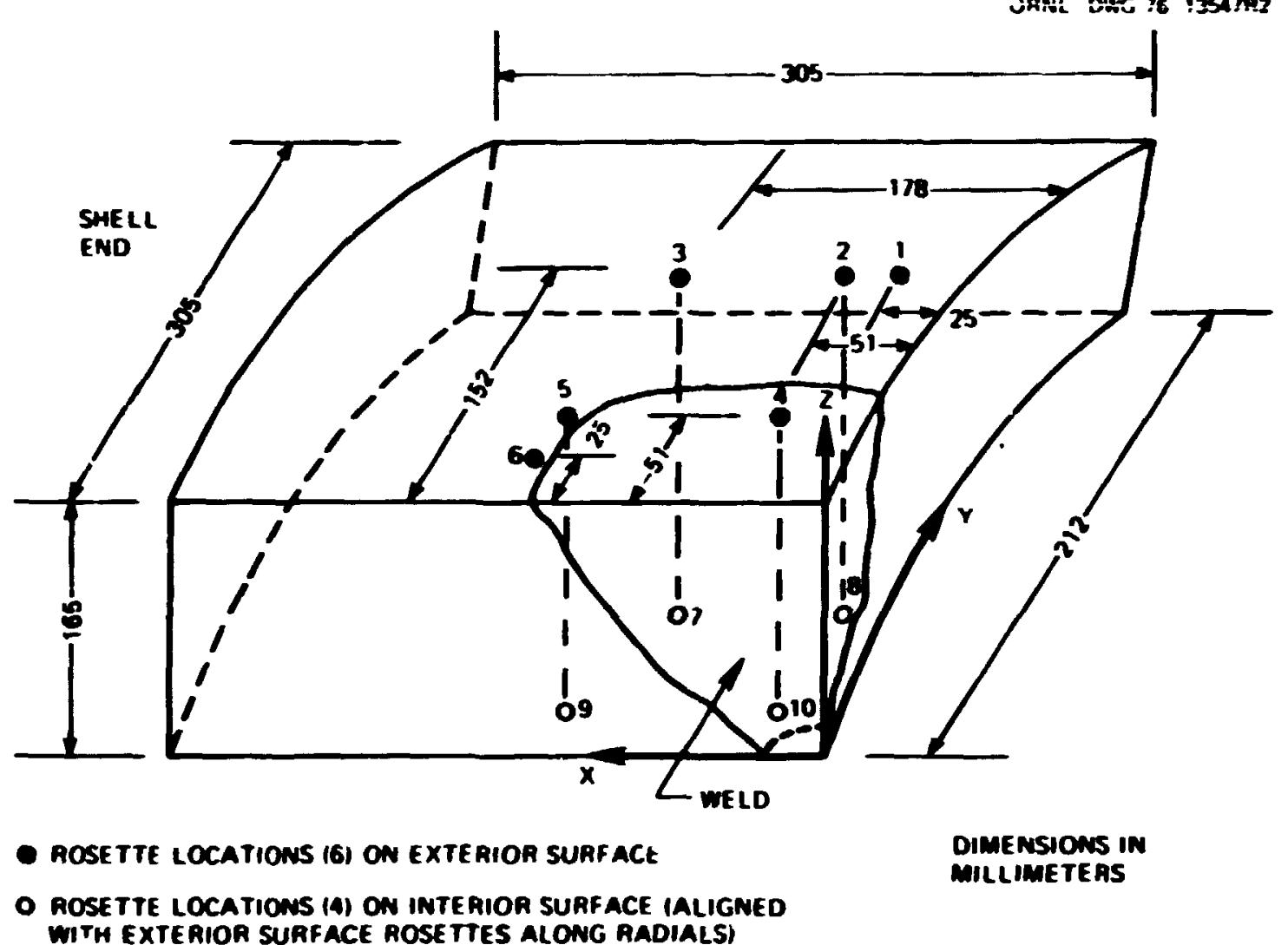

Fig. 5.6. V-9 prolongation containing the V-7A simulation repair weld, piece A, Fig. S.1. Location of strain rosettes used to estimate sectioning effects $(100=3.94 \mathrm{in.})$.

piece. Table 5.3 contains the axial and circunferentisl stresses that: were calculated from the strains given in Table 5.2. Equations (4.1) and (4.2) were used for these calculations. Figures 5.7 and 5.8 show plots of those calculated stresses as viewed from the outside cf the prolongation after the final cut.

Several least-square fits (1inear, quadratic, etc.) of the data were exanined for the purpose of extending the results shown in Figs. 5.7 and 5.8 to the axial-radial and circunferential-radial faces that were to be used for subsequent through-thickness residual stress measurements by the hole-drilling cechnique. The final choice of a scheme for fitcing and extending the data had the form

$$
\sigma_{a}=a_{0}+a_{1}, x+a_{2}, z+a_{3}, x_{2}
$$


Table 5.3. Stresses calculated from strain rosettes nounted on piece $A$ of the V-9 prolongation

\begin{tabular}{|c|c|c|c|c|c|c|c|c|}
\hline \multirow{2}{*}{$\begin{array}{l}\text { Gage } \\
\text { inc. }\end{array}$} & \multicolumn{2}{|c|}{ Af cer cut 1} & \multicolumn{2}{|c|}{ After cut 3} & \multicolumn{2}{|c|}{$\begin{array}{c}\text { Hal fway through } \\
\text { cut } 4\end{array}$} & \multicolumn{2}{|c|}{ After cut 6} \\
\hline & $\underset{(\mathbf{R P a})}{\sigma_{a}}$ & $\underset{(\text { RPa }}{\left.\sigma_{c}\right)}$ & $\underset{(\operatorname{RPa})}{\sigma_{2}}$ & $\underset{\left(\boldsymbol{r P a}_{\mathrm{p}}\right)}{\sigma_{\mathrm{c}}}$ & $\stackrel{\sigma_{2}}{\left(R_{2}\right)}$ & $\underset{(\mathrm{IPa})}{\sigma_{c}}$ & $\begin{array}{l}\sigma_{2} \\
(\text { RPa })\end{array}$ & $\stackrel{\sigma_{c}}{\left(R_{P}\right)}$ \\
\hline 1 & 151 & 3 & 162 & -48 & 163 & -49 & & \\
\hline 2 & 137 & -21 & 161 & -73 & 163 & -74 & & \\
\hline 3 & -71 & -21 & -123 & -29 & -121 & -28 & & \\
\hline 4 & -169 & 9 & -139 & -121 & -139 & -121 & & \\
\hline 5 & -37 & 29 & -44 & 129 & -45 & 129 & -43 & 131 \\
\hline 6 & -63 & 26 & -123 & -16 & -125 & -16 & -122 & -14 \\
\hline 7 & -7 & 6 & -7 & 29 & -7 & 26 & -6 & 29 \\
\hline 8 & -21 & -75 & -23 & -37 & -23 & -36 & -20 & -35 \\
\hline 9 & -29 & 34 & -46 & $-7:$ & -34 & -31 & -32 & -28 \\
\hline 10 & -100 & -68 & -116 & -25 & -116 & -25 & -116 & -22 \\
\hline
\end{tabular}

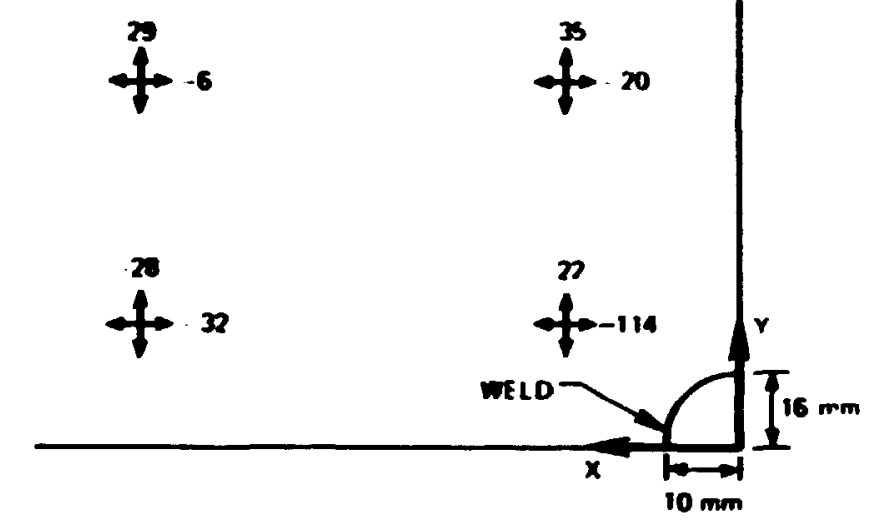

Onan Dato os issean

F1g. 5.7. Stresses (MPa) used to determine correction to throughthickness stress measurements, interior surface (1 $\mathrm{IPa}=145 \mathrm{psi} ; 1 \mathrm{~m}=$ 0.0394 in.).

and

$$
\sigma_{c}=b_{0}+b_{1}, y+b_{2}, z+b_{3}, y z,
$$

where the four coefficients in each equation were determined from the four stresses of like orientation that were closest to the radial face 

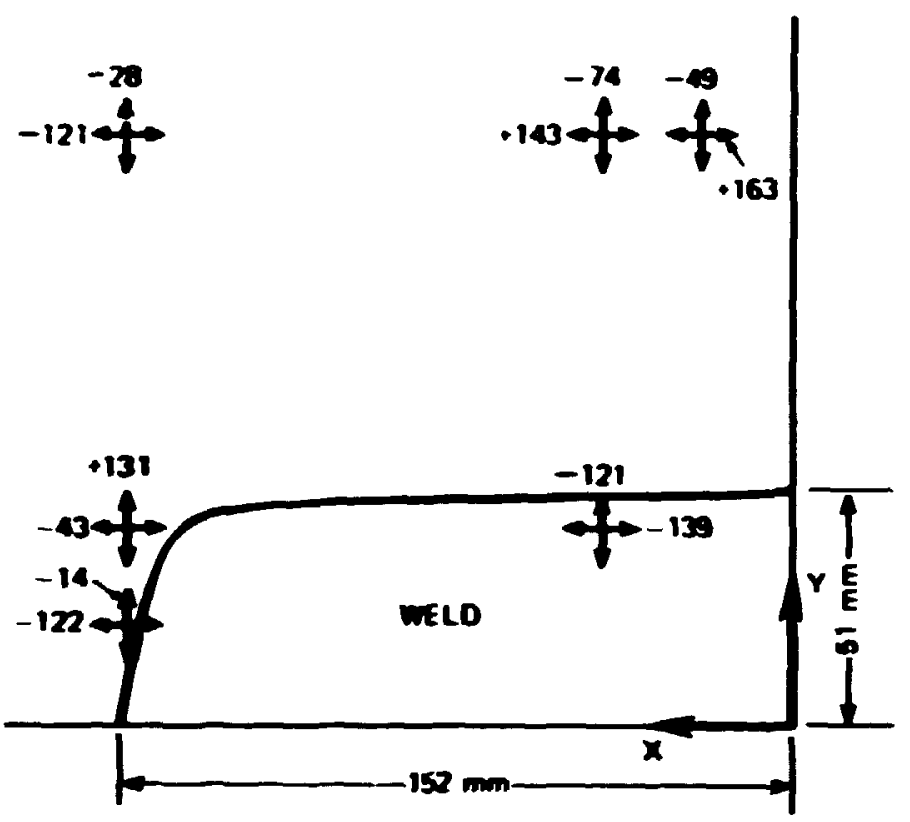

F18. 5.8. Stresses (RPa) used to deternine correction to throughthickness stress weasurements, exterior surface (1 KPa = $145 \mathrm{pat}$; 1 in = 0.0394 in.).

of Interest. Contours of the adjustent (sectioning effects with signs reversed) chat were deternined in this way and which were then added to the axial and circunferential through-thickness measurements are shown in Figs. 5.9 and 5.10, respectively.

Another appraach to correct for sectioning would be to anke an estinate based on assumed or measured surfare atresses and the effect of relaxing those stresses on the values that are actually measured. For example, the measurement of a residual stress by means of the bole-drilling techaique on a sectioned plece does not include the effect ci the strese that existed nornal to the surface prtor to cutting. If it were assuned that the normal stress before sectioning was tensile and equal to the base watal yield stress, then the correction needed for the Polseon effect would be tensile and would be approxtately $130 \mathrm{MPa}(19 \mathrm{kel})$. This value is not greatly different from the corrections deternined from strain relaxation measured during the sectioning procese. 


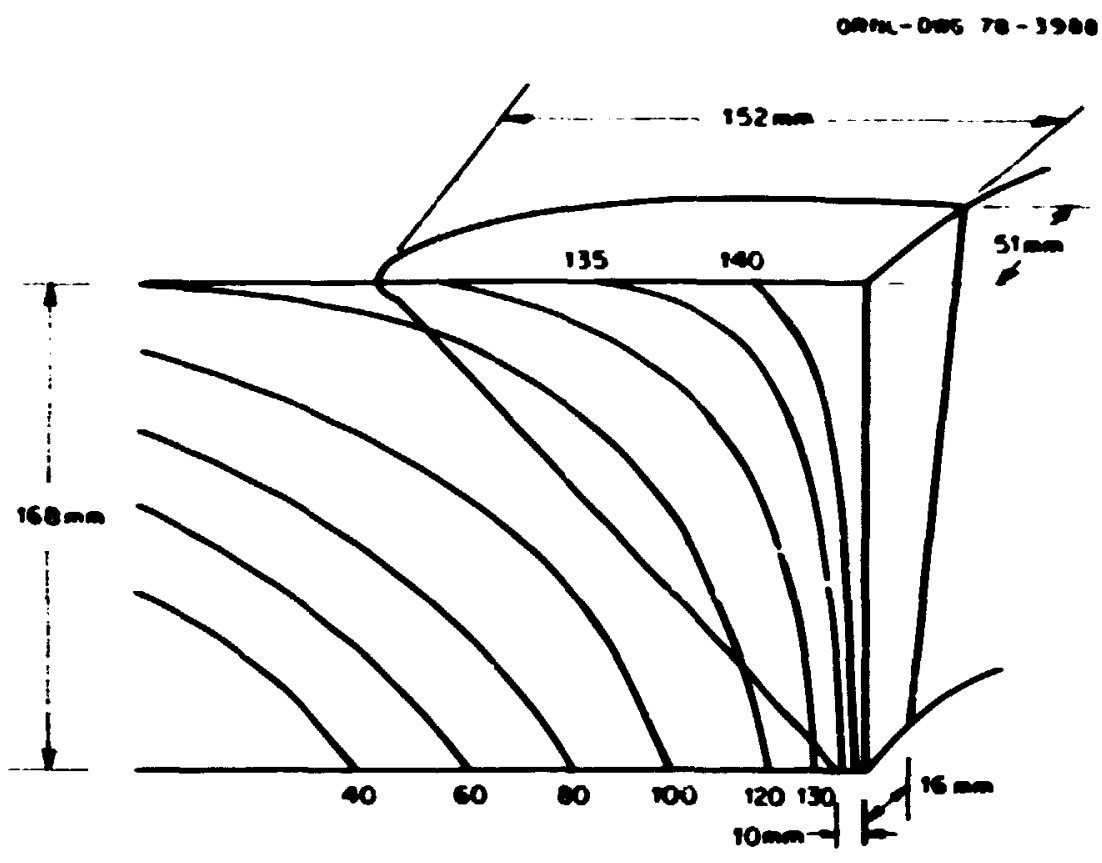

Fig. 5.9. Contours of equal axial stress (MPa) that were superposed with through-thickness axial stress measurements (1 ma $=145$ psi; 1 m $=0.0394$ in.).

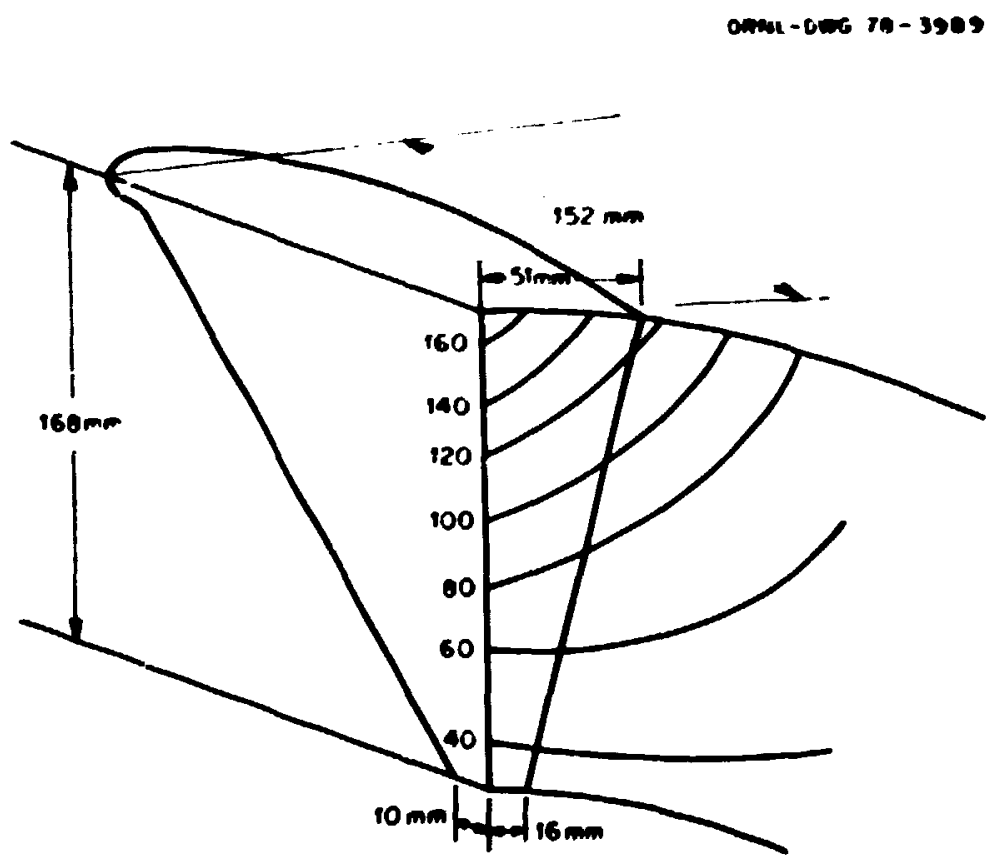

Fig. 5.10. Contours of equal circumferential stress (MPa) that were superposed with through-thickness circumferential masurements (1 MPa - 145 psi; 1 mo $=0.0394$ in.). 


\section{Surfaca Preparation}

It is well-known' that machining or grinding of a metal surface can introduce residual stresses quite close to the surface. Since the holedrilling techaique relies on a very shallow hole beine drilled on a surface, it would be particularly susceptible to spurious results caused by axchining if special precautions were not observed. For all the chroughthickness measurenent regions, a gentle grind procedure as suggested in Ref. I was enployed as the last operation. This typically means taking a large nuber of grinding passes each of which is on the order of 0.01 - $(0.0003$ in.). Rased on the results in Ref. 1 , it was concluded that the gentle grind procedure precluded the need to make a correction for skin effects due to saving. (See the discussion in Appendix B.) It was decided not to perform a gentle grind on the interior and exterfor surfaces of the vessels except to evaluate achining effects $180^{\circ}$ from the repair zone in the V-8 vessel (see Appendix G). Since some cosinetic gr fnding was performej on the completed weld by the fabricator, some grinding effect ay also be present. No compensation was employed for this ef fect.

\section{Reference}

1. L. J. Nowikowski, J. Maranchik, Jr., and M. Field, "Distortion and Residual Surface Stress in Grinding and Milling of High-Strength Steels," SAE d. 69(8), 41-45 (August 1961). 
b. SUTARY OF EXPERIHITIAL RESULTS

This chapter selectively sumarizes the residual stress deternimathons ande on the $V-7$ and $V-8$ series of repair welds and sfinulation repair welds. All simulation weld through-thiciness data in this chapter contain the corrections for sectioning described in Chapter $S$ and are thus to be coasidered best estinates of the stresses that existed in the velds prior to sectioning. Some data, such as the radial streases in the repair weld or stresses for wich a correction for sectioning could not be deternined (e.8., V-7B simulation), are ofitted from this chapter because they are not of general incerest. However, all of the residual stress measurenents ade on the spectinens are contained in the appendices to this report. Residual streas neasurenents taken at points far removed ( $90^{\circ}$ or wore measured fron the weld) were typically low. This was as expected since the weld repair spechens had been previously stress relieved. Hole-drilling neasurenents on the surface of the V-8 vessel were influenced by the prior machining of the vessel during its fabrication. A discussion of those measurenents is contained in Appendix G.

Axial and Circuferential Residual Stresses on the Surface of the $V-7 B$ Vessel

Figures 6.1 and 6.2 show the surface axial and circunferential residual stresses chat were induced by the weld repair of the V-7B vessel. These values were deternined from weldable gages and by the method discussed in Chapter 4. While these values pertain strictly to the change in stress, they are close to the absolute residual etresses since the vessel had been stress relfeved during fabrication. The gages were placed approxiancely 51 m (2 in.) from the weld cavity in order to ensure their teaperature linitation.

Circunferential Residual Stresses Throuth the Thickness of the V-7A Simiation Repelr Held

F1gure 6.3 shows through-thickness circuferential stress weasuremeats (In MPa) induced in and near the V-iA simulation repair weld. The 


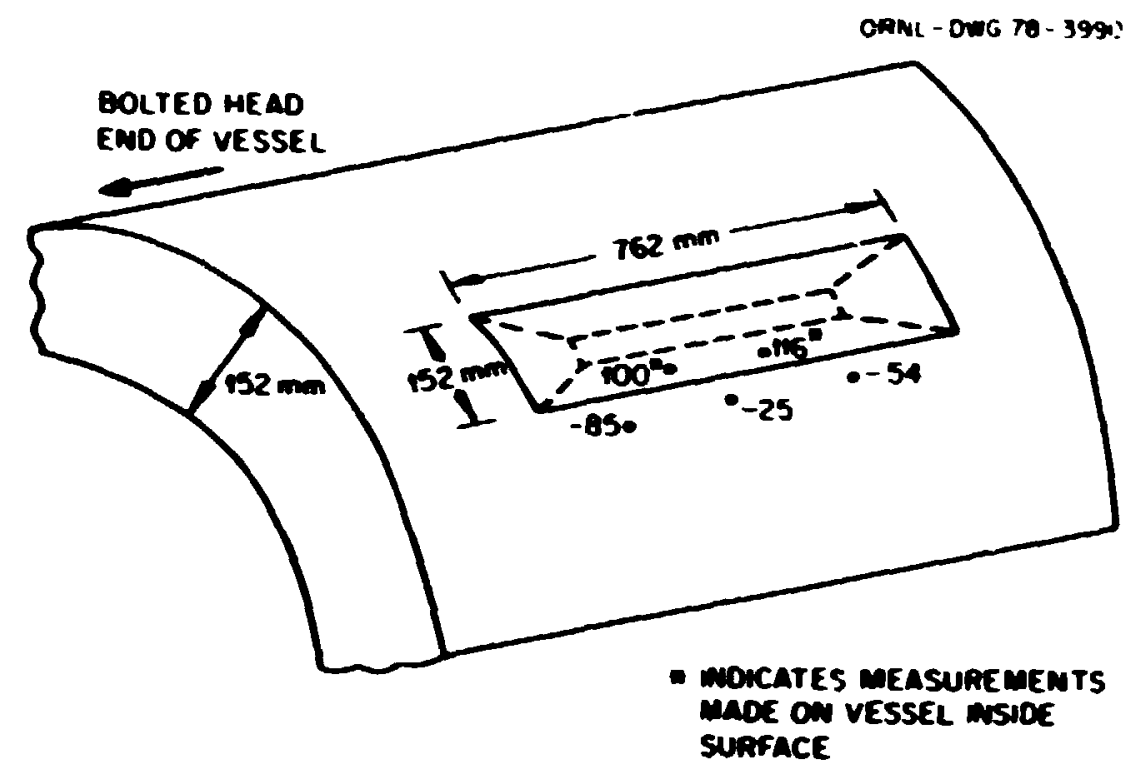

Fig. 6.1. Axial residual stresses (IPa) measured on base metal 51 man from the $V-7 B$ through-thickness weld repair as deternined from gages mounted on the vessel inside and outside surfaces and monitored during welding ( $\mathrm{MPa}=145 \mathrm{psi} ; 1=0.0394 \mathrm{in}$.).

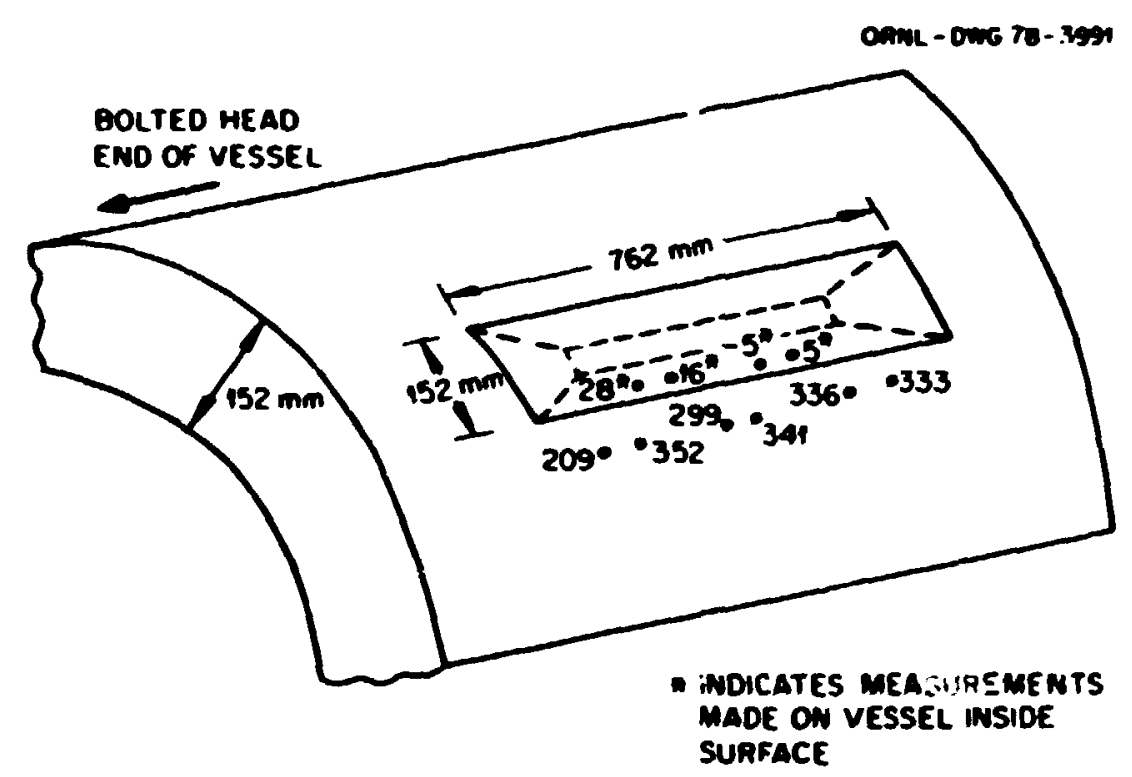

Fig. 6.2. Circumferential residual stresses (MPa) measured on base metal 51 from the V-7B through-thickness weld repair as determined from weldable gages mounted on the vessel inside and outside surfaces and monticored during welding (1 MPa $=145 \mathrm{psi} ; 1$ m $=0.0394 \mathrm{in.}$ ). 


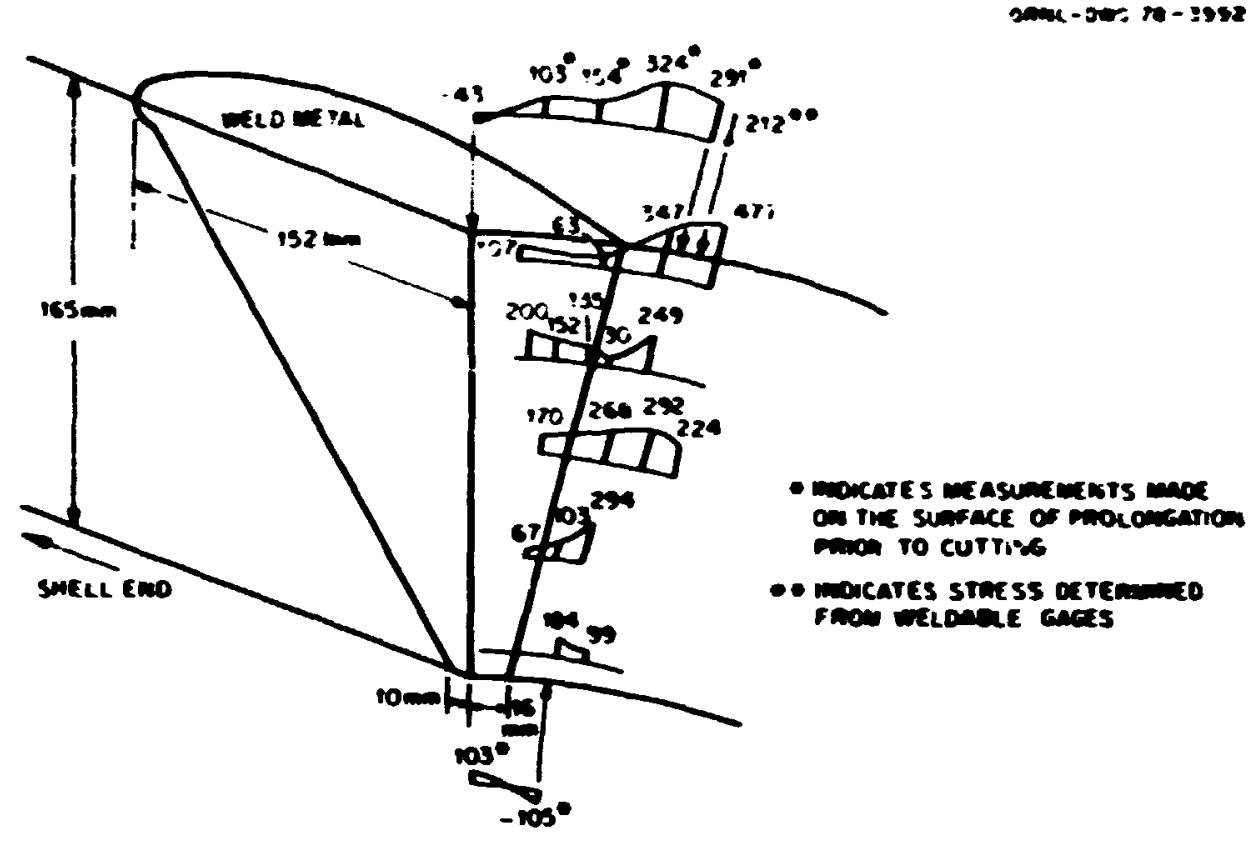

Fig- 6.3. Circuferential residual stresses (MPa) through the V-7A simulation repair veld, piece A, Fig. 5.1 ( $1 \mathrm{MPa}=145 \mathrm{psi} ; 1=$ 0.0394 in.).

values denoted with an asterisk are surface measurenents that were ande on the specizen using the hole-drilling technique prior to any sectioning. The througin-thickness values in the figures are the residual stresses existing in the specinen prior to the sectioning which was necessary for access to radial planes. They were deternined by superposing the correction for sectioning fron Fig. 5.10 on the actual hole drilling results. The data in Fig. 6.3 indicate large circuferential stresses in the base metal adjacent co the weld cavity and auch lower residual atresses in the weld wetal itself. The bace wetal data agree with the V-7B circunferential stress data show in F1gs. 6.1 and 6.2. The low stresses in the weld metal were unexpected. These measureneats were ande at both WRDC and ORN and exhibit a distribution (1.e., high tensile stress in adfacent base metal and relatively lower stresses in the weld metal) consistent with $V-7 A$ axial data and V-8 data which w11 be described later is this chapter. A probable explanation for the unexpectedly low stresses in the weld metal is chat the weld wetal was stress relieved by the heat input from subsequent weld passes. 


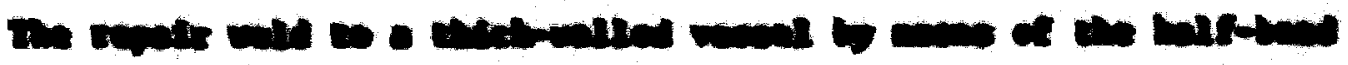

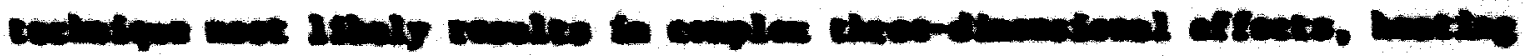

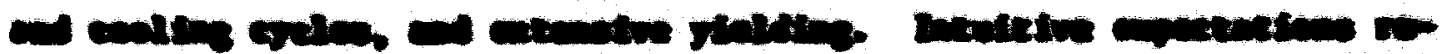

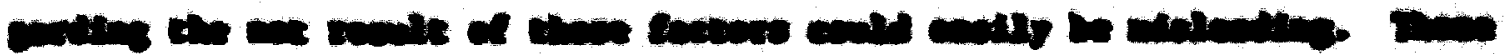

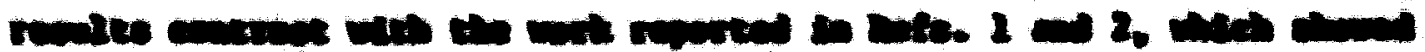

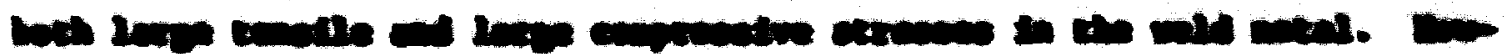

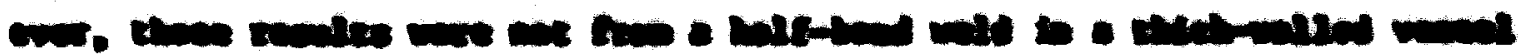

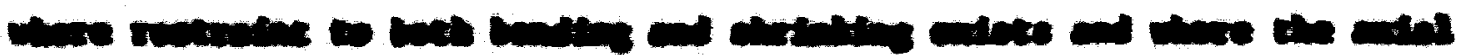

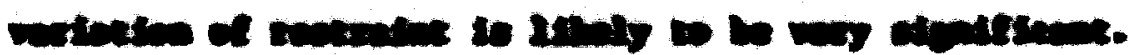

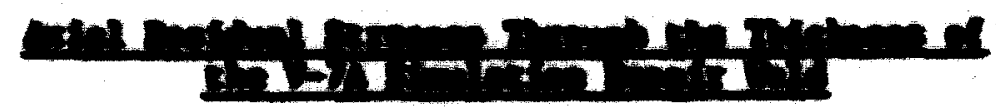

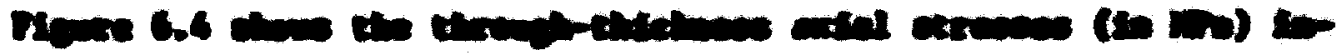

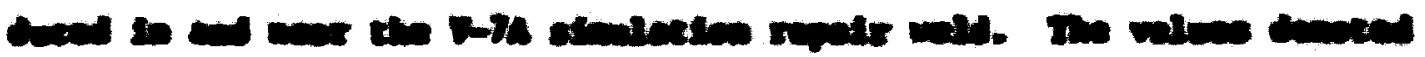

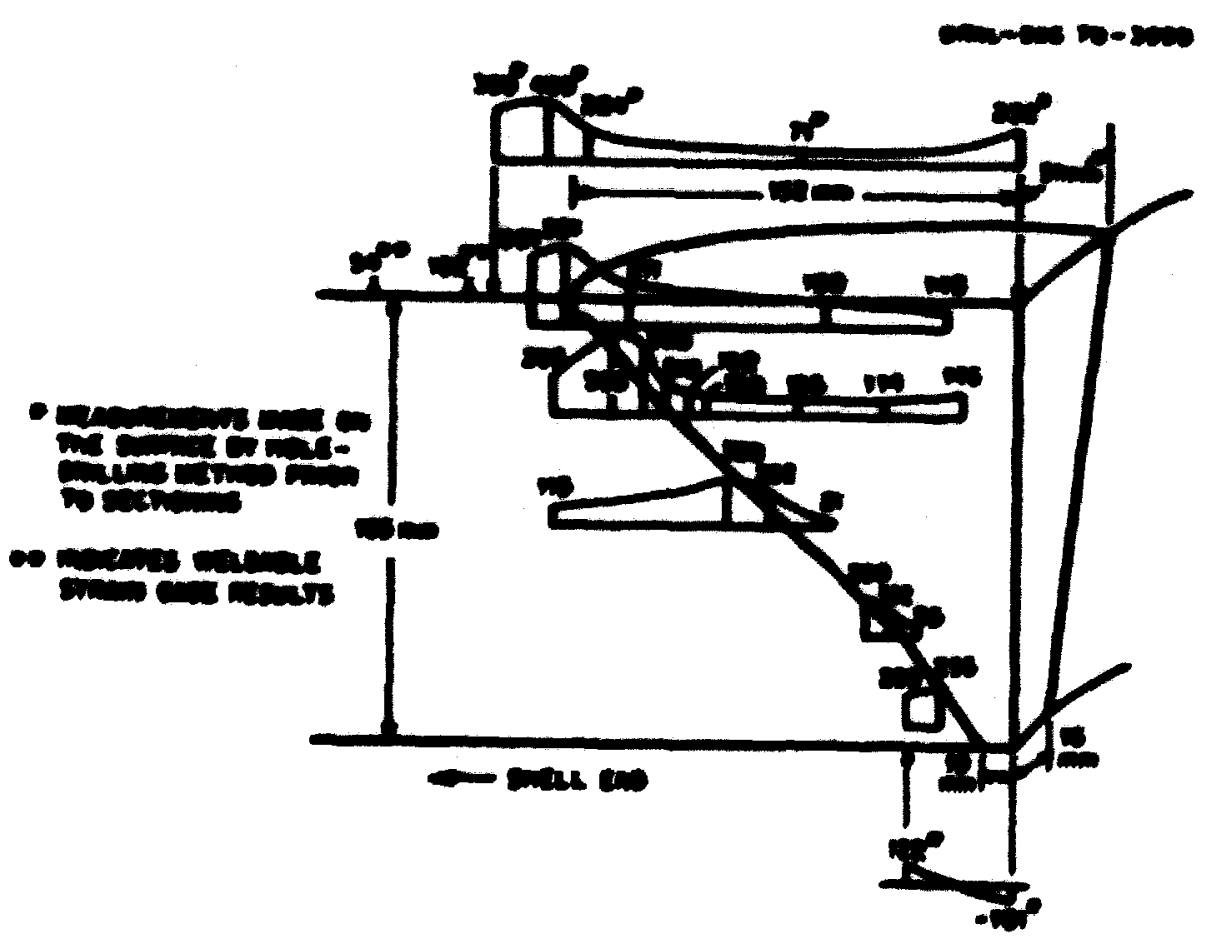

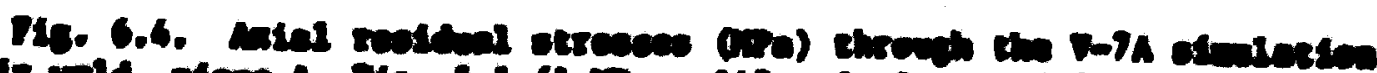

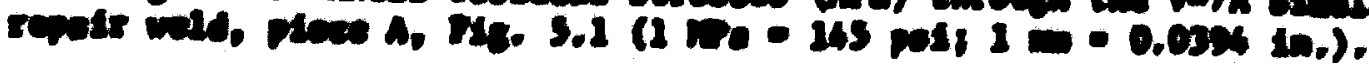


with an asterisk were determined by the bole-drilling rethod on the surface prior to any cutting. The chrough-thickness values consist of holedrilling measurements with a correction for sectioning taken from Fig. 3.9. Wile the hole-drilling surface measurements steen to be in good agreesent with the through-thickness values, the surface neasurements were not made after a controlled gentle grind and should ti:erefore not be considered as reliable as the through-thickness neasurenents.

\section{Axial and Circueferential Residual Stresses on the Surface of the $V-8$ Vessel and its Prolongation}

Figures 6.5 and 6.6 show the superposition of the weld cavity outlines on the outside surface for the V-8 and the V-8 simulation repair welds (i.e., they were identical) and the axial and circunfereatial residual stresses that were deternined from weldable gage data. The asterisk by a residual stress in the figures is used to indicate that the residual stress yalue applies to a measurenent that was taken from a position cencerer under the weld and located on the inside surface of the vessel. is in the case of the $V-7$ series residual stress data, these results indicate high censile circuaferential residual stresses exist in the base metal adjacent to the repair. There is good agreement between the $v-8$ welds in

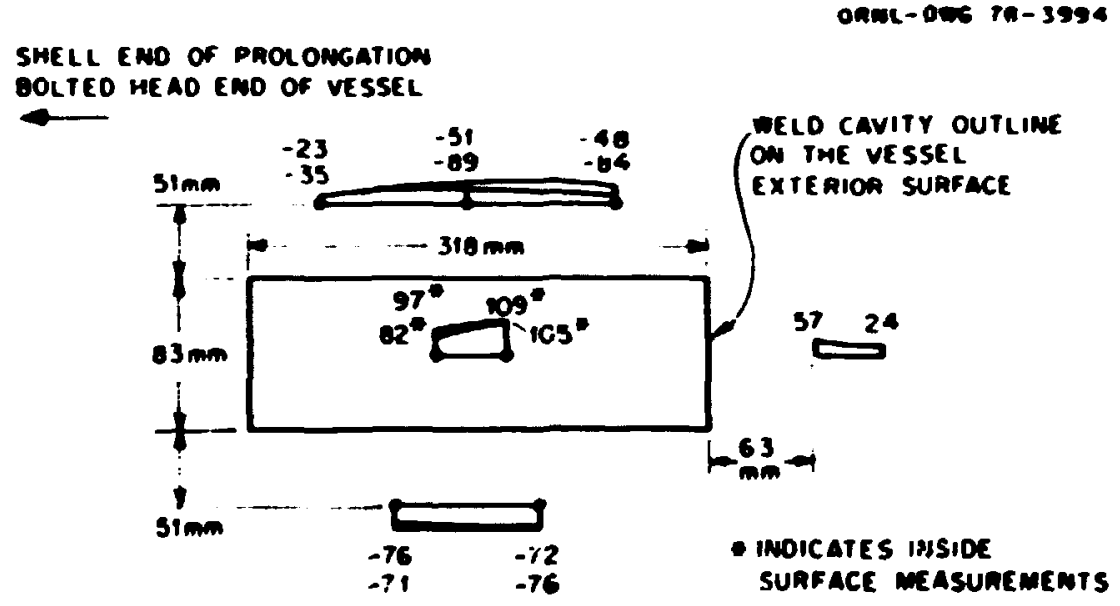

Fig. 6.5. Surface =xial residual stresses about the $V-8$ and $V-8$ 5 inulation repair welds ( $1 \mathrm{MPa}=145 \mathrm{psi} ; 1 \mathrm{~m}=0.0394 \mathrm{in.}$ ). 


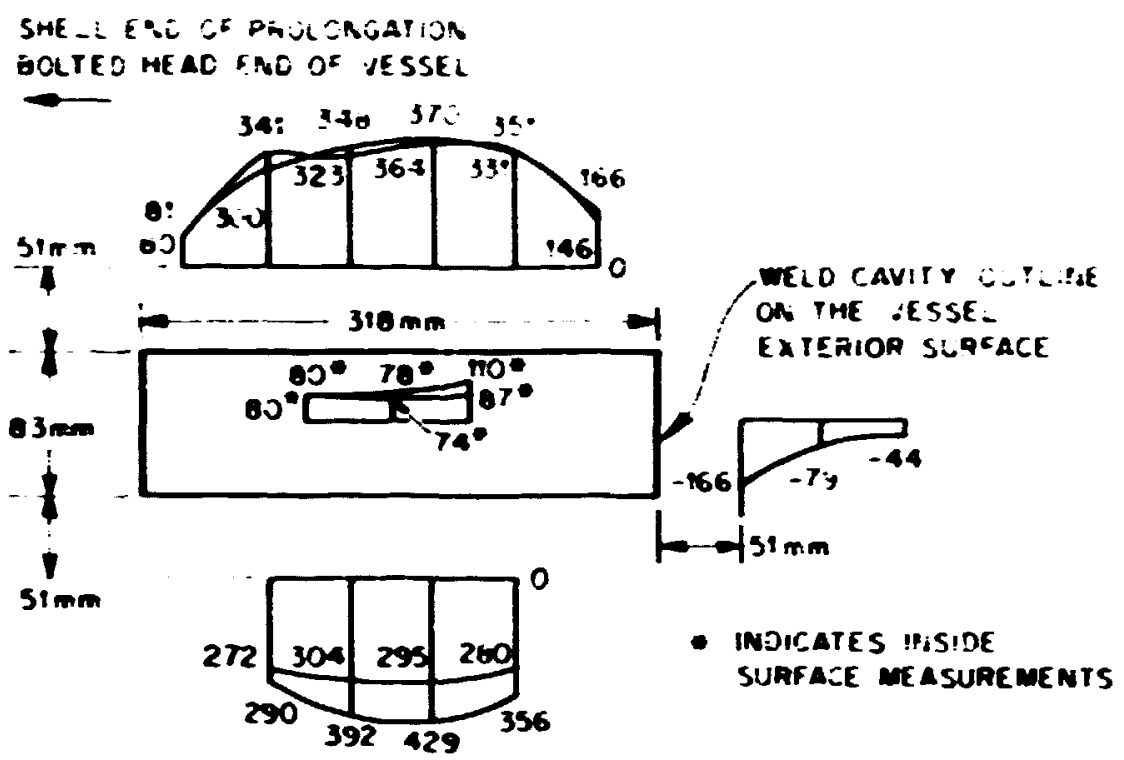

Fig. 6.6. Surface circumferential residual stresses (APa) about the $v-8$ and $V-8$ simulation repair velds $(1: T ;=145$ psi $; 1=0.0394$ in. $)$.

the vessel and the smaller prolongation. The difference in the circumferential residual stresses in the stran welds between the two repairs (the simulation having the lower values) may be the resislt of variations such as yicld strength inherent in seam weId material.

\section{Circuferential Residual Stresses Through the Thickness of the $i-8$ Simulation We Id}

Figure 6.7 shows the circunferential residual stresses that are estinated to have existed in the V-8 siaulation prolongation prior to cutting it into two equal halves, which remained complete cylinders (Fig. 5.1). The values marked with an asterisk are based on the weldable type surface measurements shown in Fig. 6.6. The through-thickness va! ues were determined from hole-drilling measurements and a correction for sectioning taken from Fig. 5.5. Reference 3 contains residual stress data from a 15.2-cm-thick (6-in.) flat plate that had been repaired using the half-bead technique. The repairs were made to cavities penetrating approximately halfway through the plate and which had long rectangular 
OANL-OWC $76-3: 36$

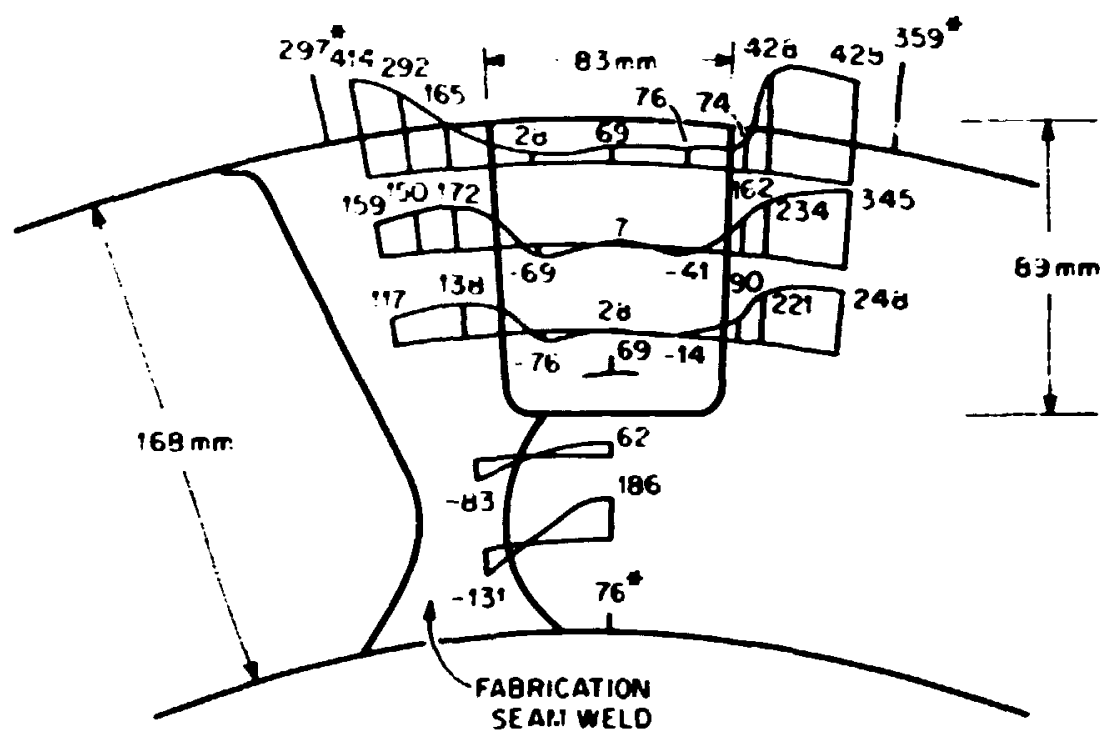

- indicates surface MEASUREMENTS MADE WITH WELOABLE STRAN GAGES

Fig. 6.7. Circumferential residual stresses (MPa) through the V-8 simulation repair weld, prece B, Fig. 5.1 ( $1 \mathrm{PLa}=145 \mathrm{psi} ; 1 \mathrm{~mm}=$ 0.0394 in.).

shapes with cross sections similar to those of the V-8 simulation repair weld. That work showed high tensile residual stresses in the weld metal. The measurement technique used for the data in Ref. 3 involved shaving material off one side of the specimen while simultaneously monitoring strain gages on the side opposite that being shaved. This measurement technique rends to average results for cases where gradients are significant. The averaging plus the difference in constraint between a flat plate and a cylinder may account for the difference between the results reported in Ref. 3 and those presented here. 


\section{References}

1. D. A. Ferrill. P. B. Juhl, and D. R. Miller, "Measurements of Residual Stresses in a Heavy Weldment," heï. Ses. Sieppi., 5045-5135 (November 1966).

2. Y. Ueda et al., "Transient and Residual Stresses from Multipass beld in Very Thick Plates and Their Reduction from Stress Relief Annealing," Third International conference on Pressure Yessel fecholog.', Part II, :iaterials and Eabrication, $\therefore$ ril $17-i 2,1.77$, American Society of Mecha"s 1 Engineers, New York.

3. N. C. Binkley and R. W. Hermann, "An Inservice Reactor Repair Simulation," Welding in iliclear Engineering, Deutscher Verlas fur Schweisstechnik, Dusseldorf. 1974. 


\section{7. concllisions}

The general conclusions from the residual stress measurements in the vicinity of the half-bead weld repairs made to the HSST in:-rmediate pressure vessel and prolongations are

1. Low tensile and compressive circumferential and axial residual stresses existed in the weld metal;

2. the base metal adjacent to the weld repairs had tensile residual stresses close to the yield stress;

3. the highest tensile residual stresses in the base metal tended to be on the order of 25 to 50 from the heat-affected zone.

With regard to residual stress measurement techniques, it was concluded that

1. The hole-drilling technique for measuring residual stresses is versatile and effective. A compensation for fictitious stresses that are introduced during drilling should be employed when a mechanical drill is used.

2. Cutting or grinding on surfaces that are to be used as sites for hole-drilling type residual stress measurements can cause misleading results. Controlled gradual removal of surface material is an effective means of reducing or eliminating these spurious skin effects. 
APPENDICES 
Appendix A

MELDING PROCEDURE SPECIFICATIOA

Appendix A is extracted fron Welding Specification No. W-HB-105, LOW Hydrogen Electrode Hanual Shielded Metal-Are Helding for "Half-Bead" Repair Welding, which was authored by P. P. Holz, ORNL. The extract fron the specification presented here is linited to that section primarily concerned with a description of the procedure that was used in the repair welding of vessels V-7B, V-8, and their companion prolongations. There was a siailar specification for the original V-7A vessel and siculation repair welds. The $V-7 A$ specification peraitted the vessel and prolongation to be welded in a flat position with vessel axes horizontal, while the V-7B and V-8 welds were made in the vertical position with the vessel axes vertical. Figure A.I containa complete decails for the repairs to incerwediate test vessels V-7B and V-8, for procedure qualification prolongation V-8, and for miscellaneous practice and specimens fabrication in connection with the vessel repair.

\section{Part I - Welding Procedure}

\section{Welding qual if ication}

All welding in accordance with this procedure shall be done by weldew qualified and currently certified under Part II (pages 13-15) or under Section IX Paragraph NB 4300 of the Code for a procedure having the same essential variables for welding performance qualification as this procedure. Welder certication papers shall be avallaile at the fob site at all times.

2. Base metal

The base metal w11l be low-alloy, high-strength carbon steel plate: (ASTM A533, grade B, class 1, or equal), P Number 3, Group 3 (Table QN 422, Section IX of the Code). 


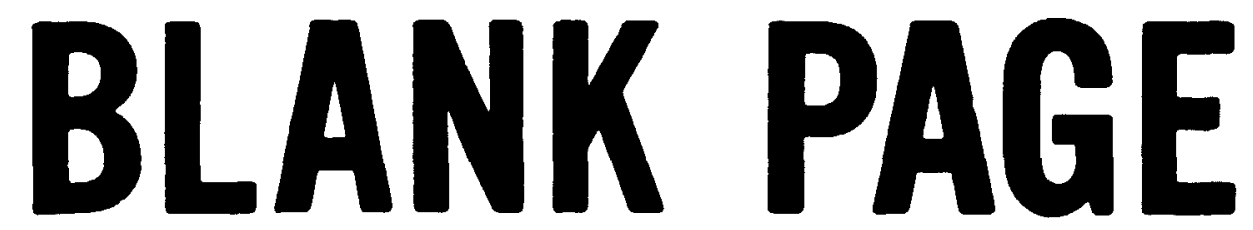




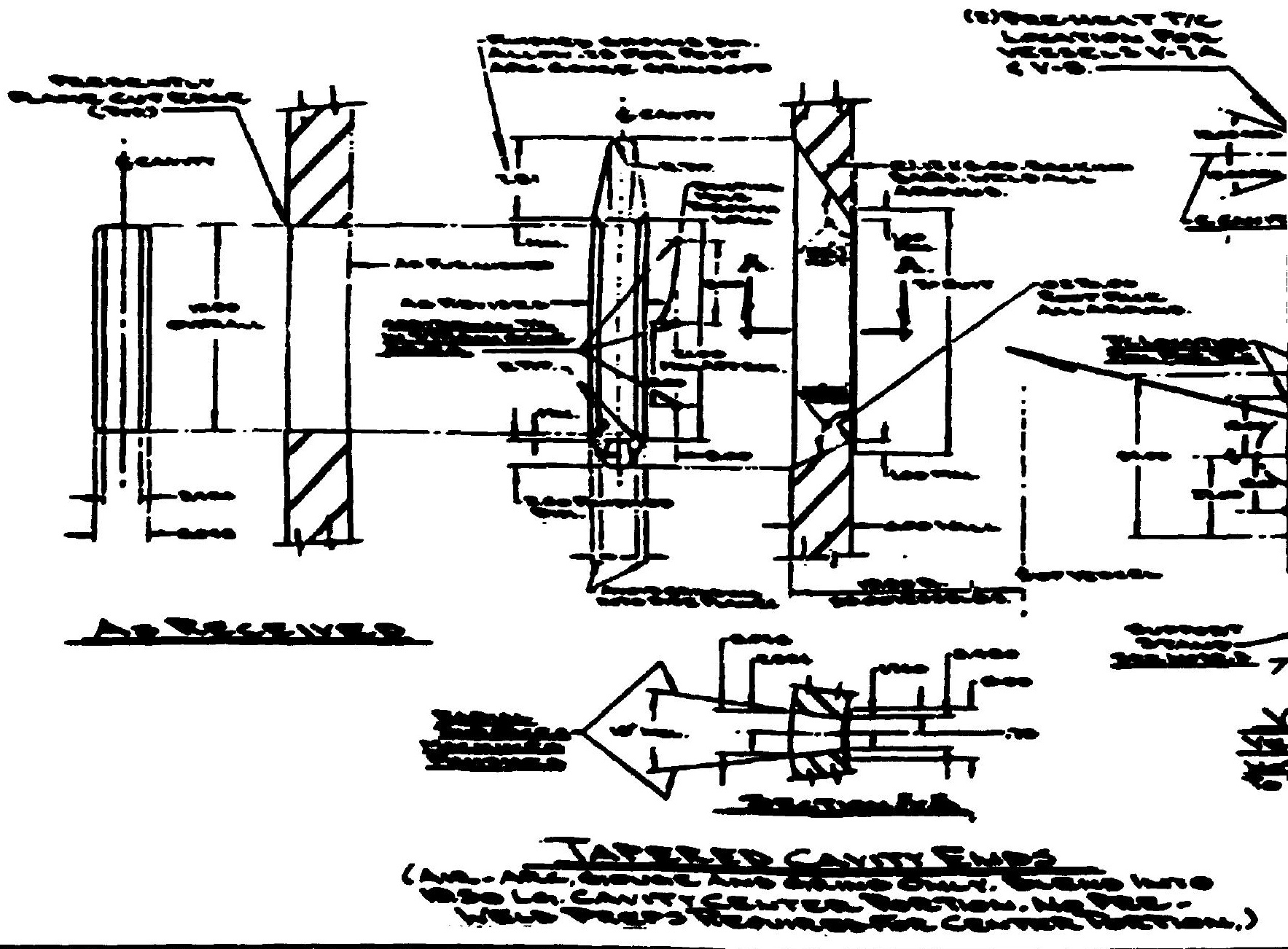

P18. A.1. Repair de

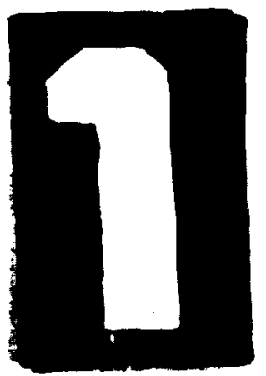
Welding (Source: Hestin Division, ETSK Drewing 3 



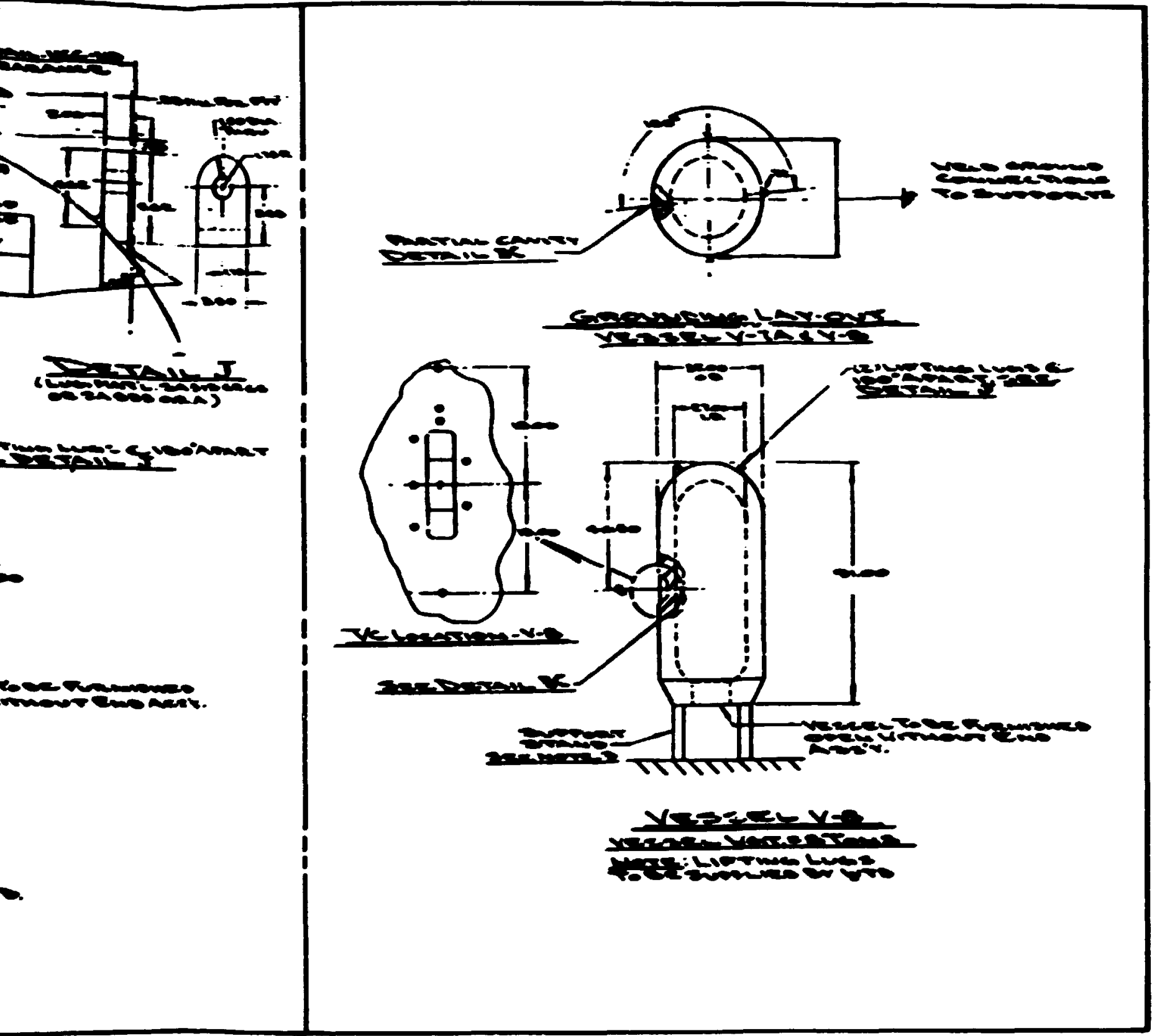

se Tampa Division Half-Bead ration, Hestinghouse Tampa 


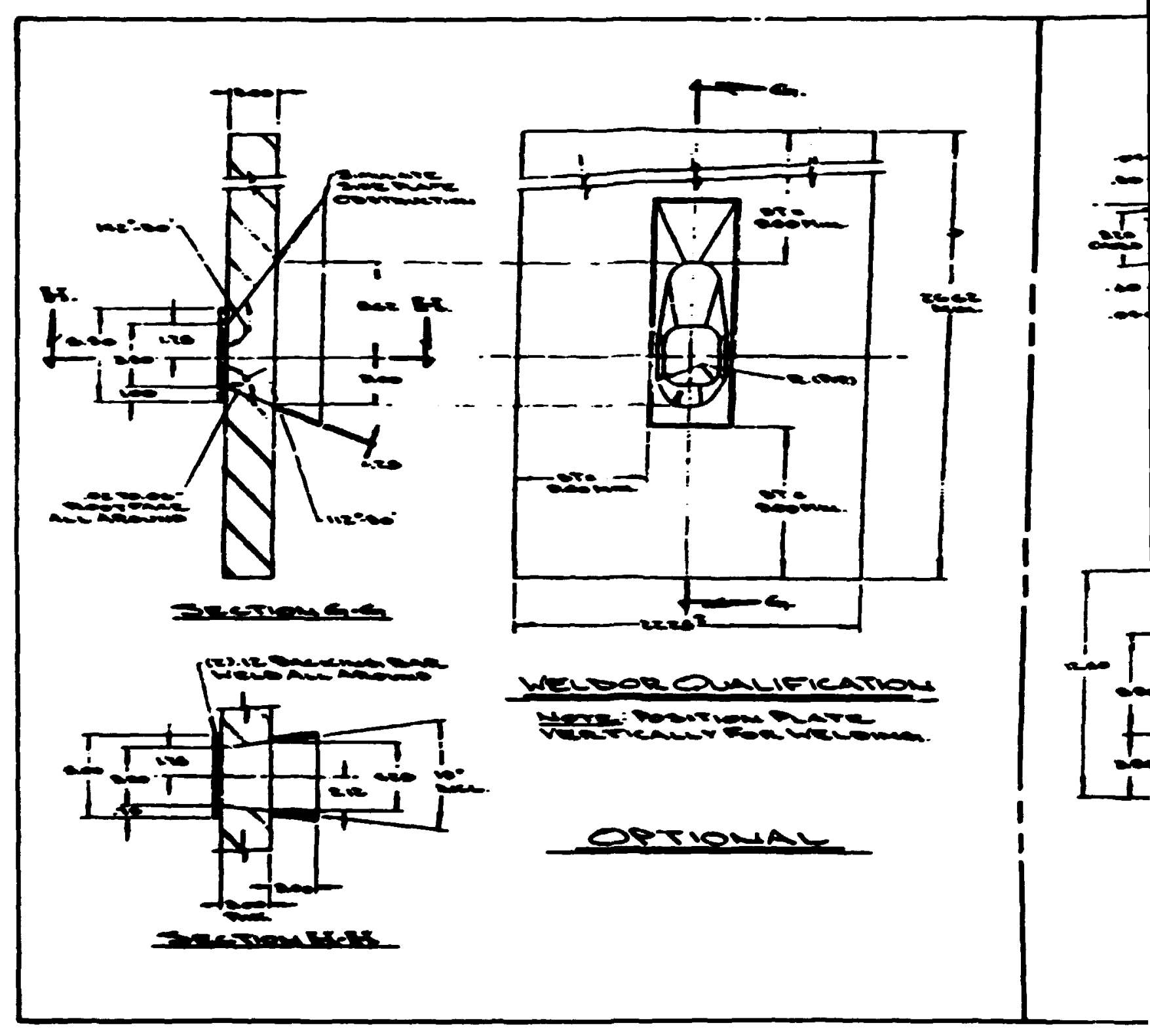

Fí 


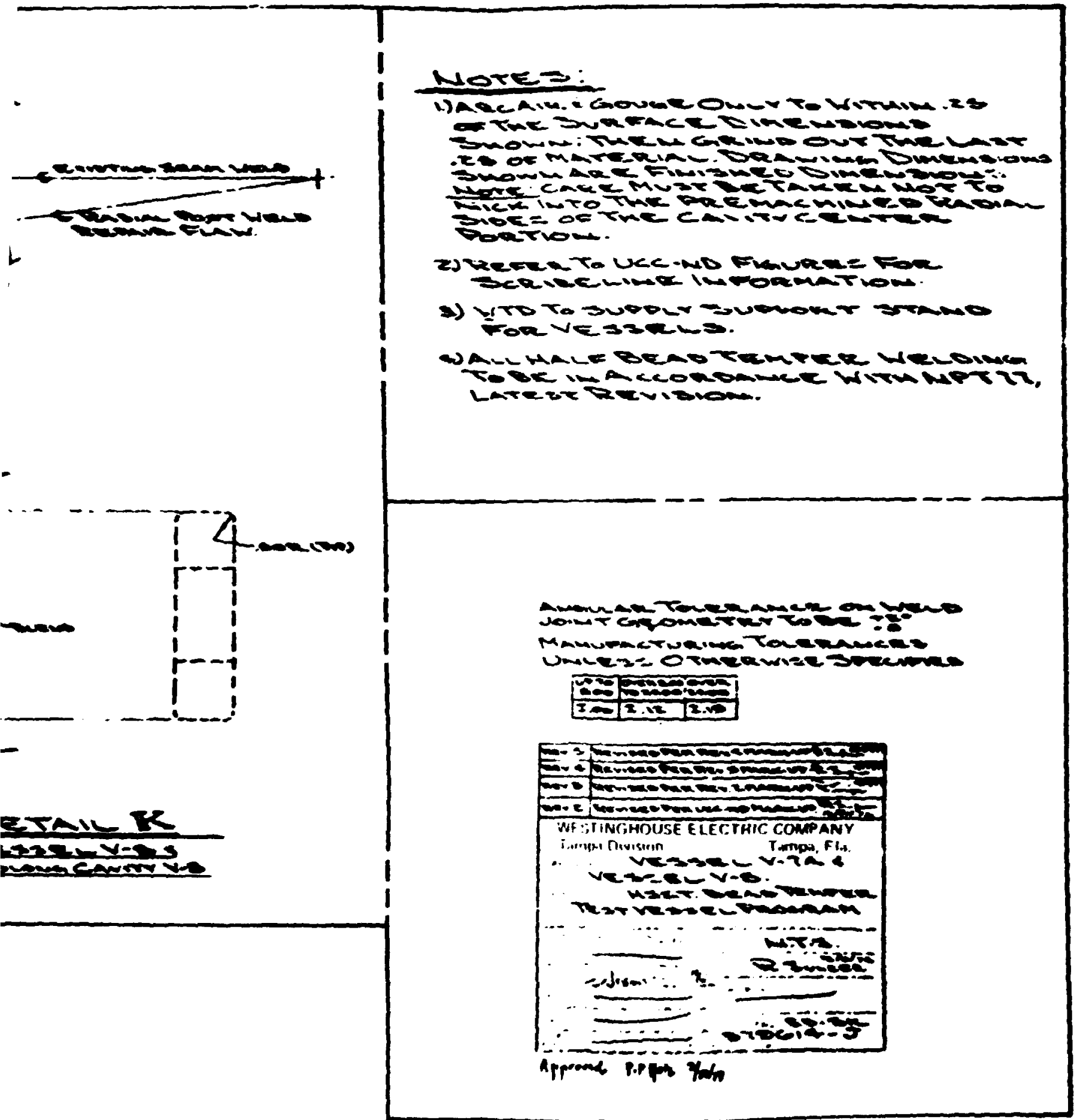

(nued)

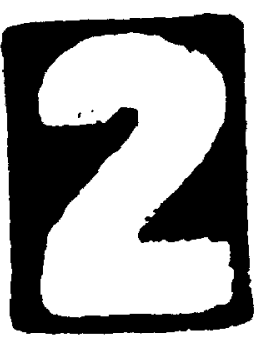


BLANK PAGE 

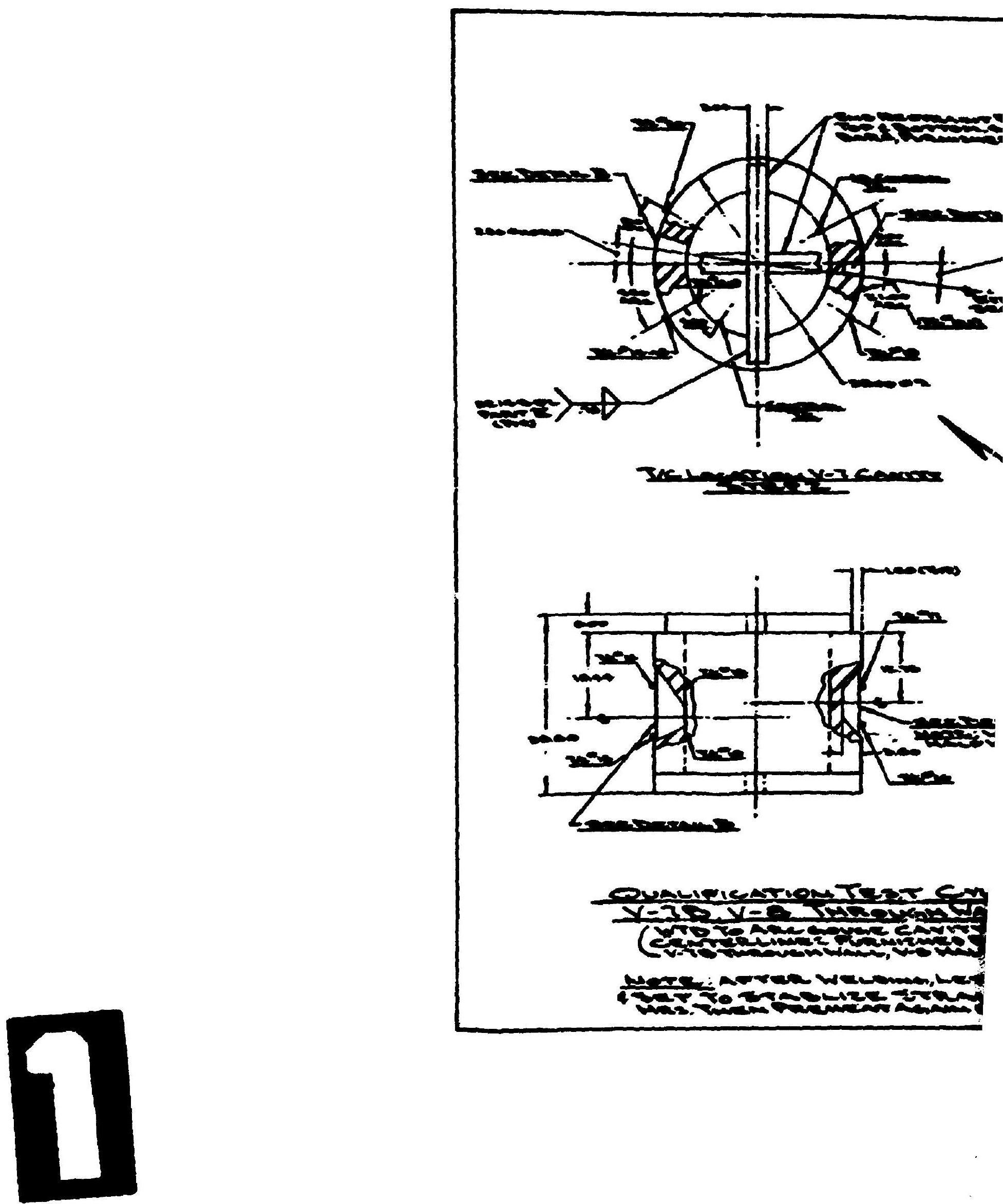
BLANK PAGE 
OANL-DWG 75-6373
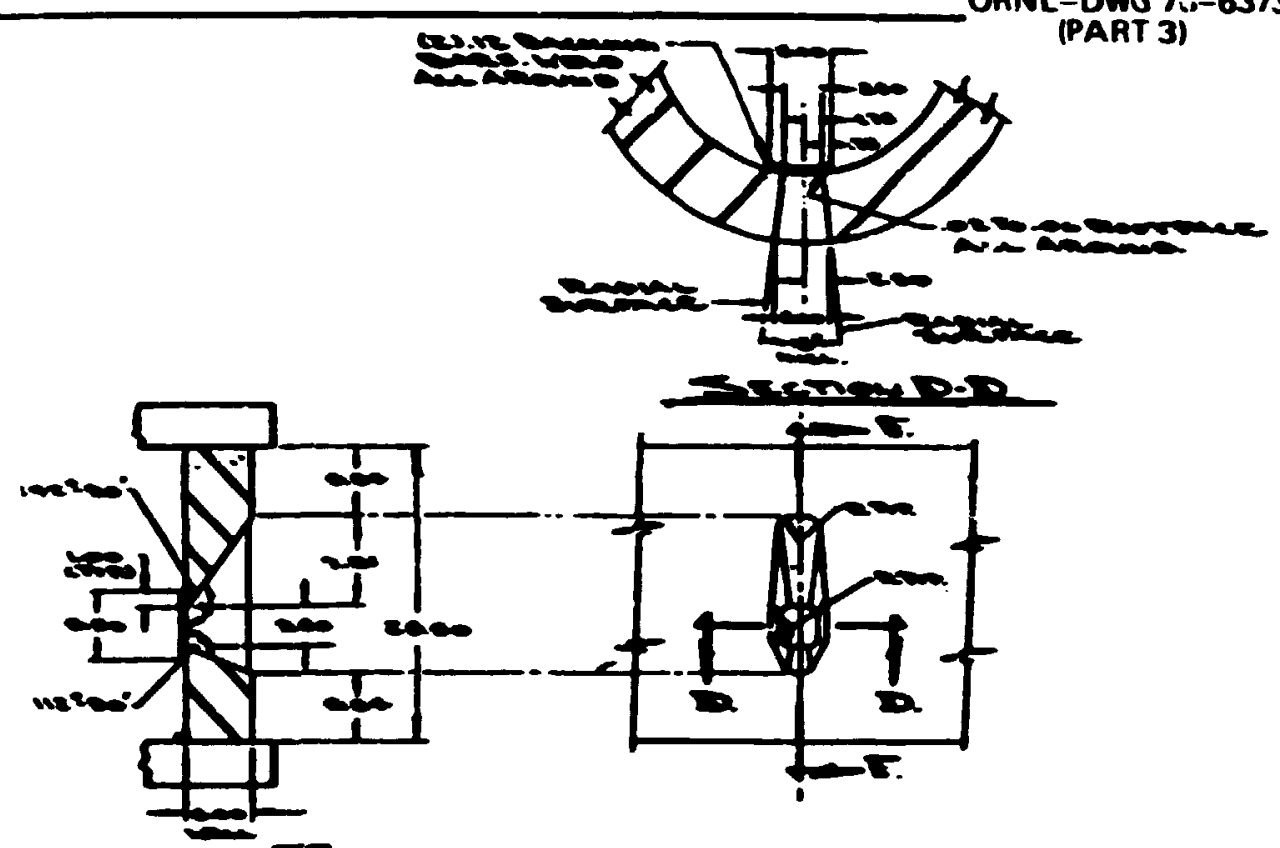

rex

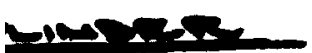

(i)

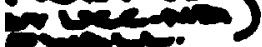

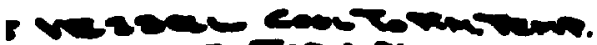

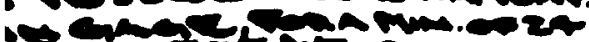

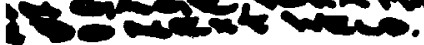

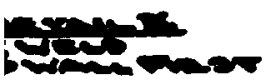
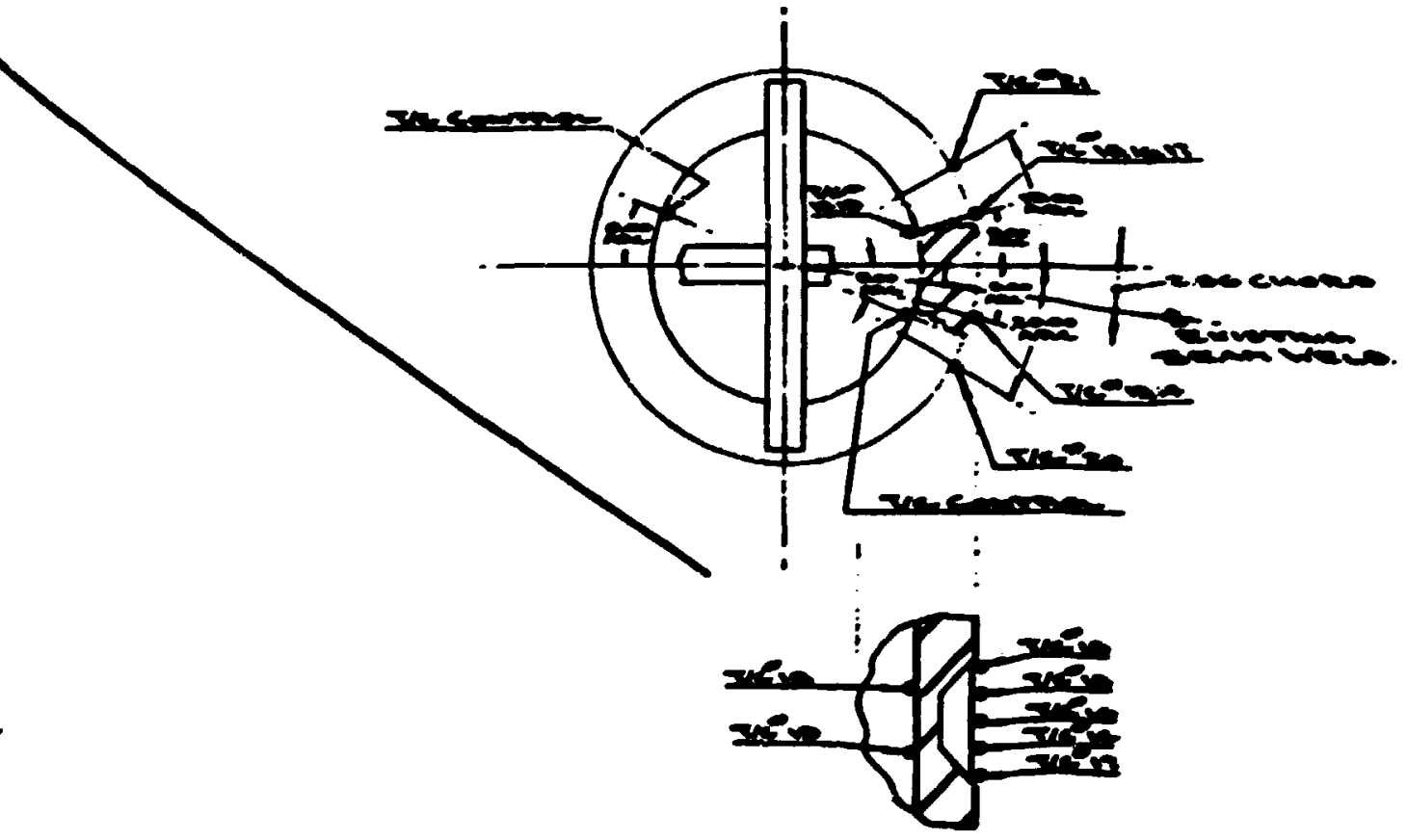

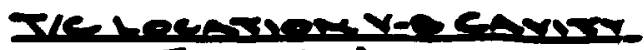
xeser

Fị. A.1 (continued) 


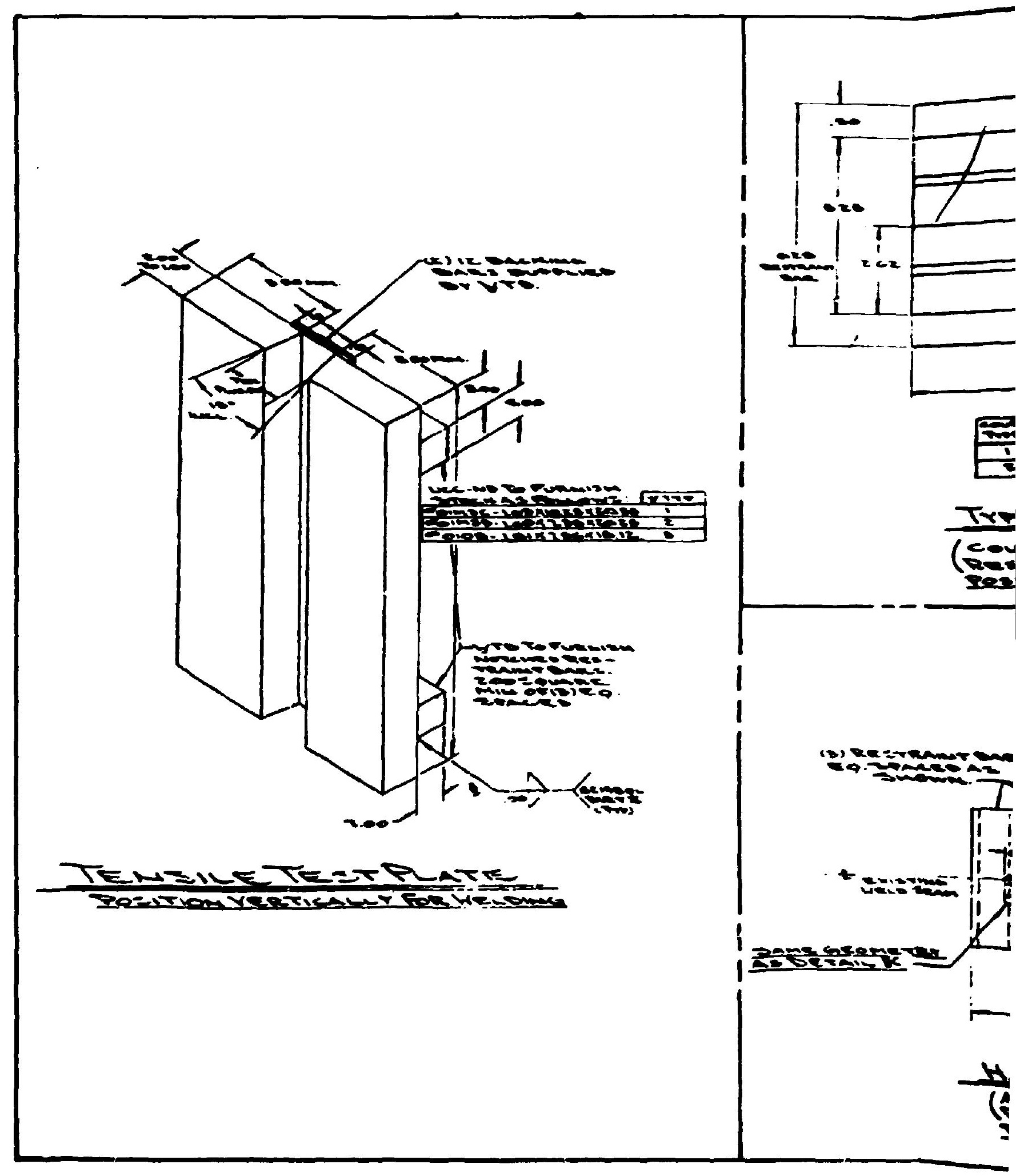

Fig. A.1 (continued) 

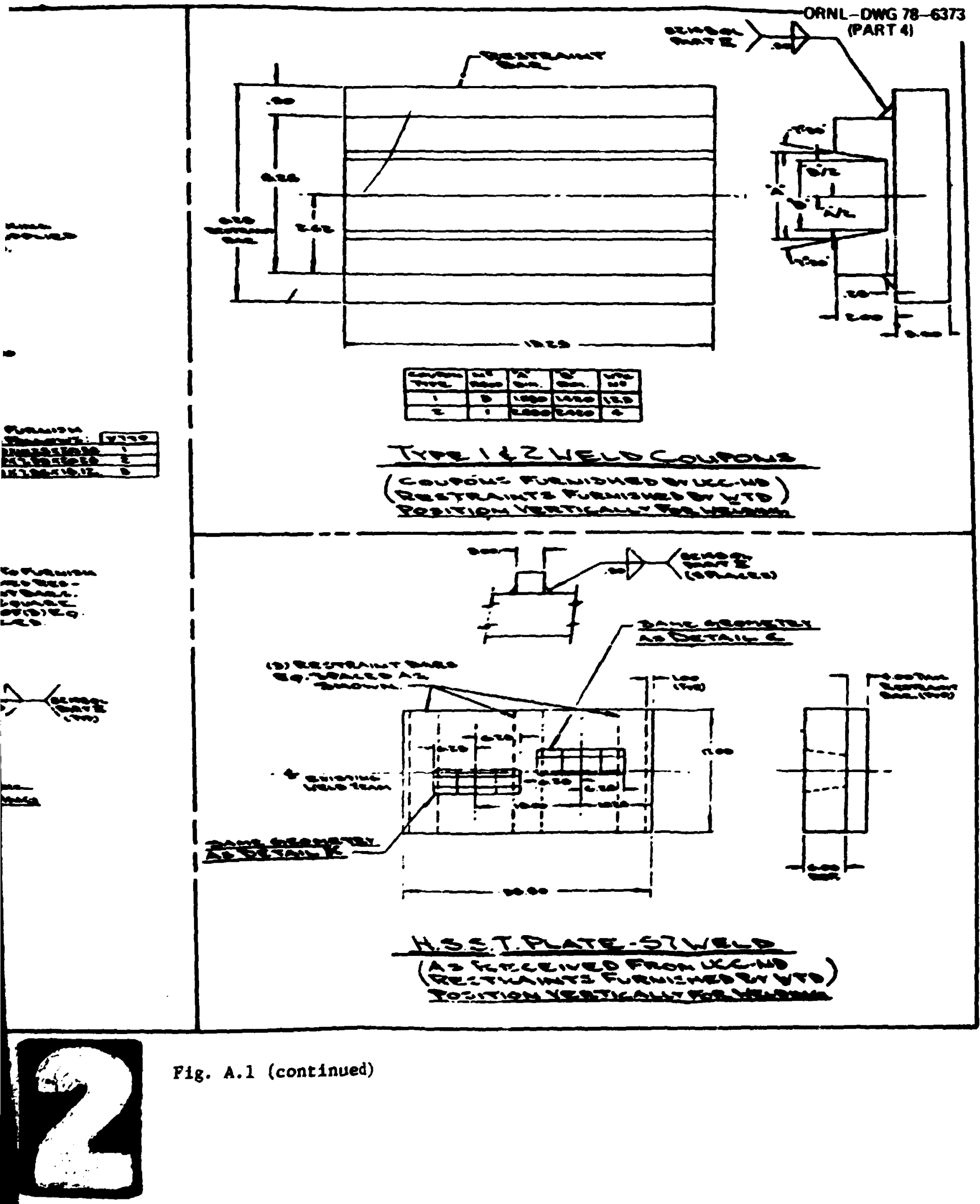

F1g. A.1 (continued) 
BLANK PAGE 


\section{Filler netal}

The filler metal shall be covered lowalloy steel electrodes and shall conform to the requirements of Specificution SFA-5.5, AWS Classification E8018-C3 of Section II of the Code, or, If the fabricator so elects, shall conforn to such other specifications as my be previously approved in witing by UCC-ID. Electrodes shall be clean and dry, and the flux shall not be cracked or spalled. (See Care of Welding Electrodes, Section 8 of Part I of this specification.) Tests of welding materials shall confor co Subarticle NB-2400 of Section III. Evaluation of each lot of weld metal shall be based upon the manufacturer's certification test report (supplied by the fabricator) and approved in writing by UCC-ND.

\section{Electrical characteristics}

The fabricator shall deternine appropriate velding voltage and amperages. As a guide, the following conditions are suggested. Direct current at 20 to $26 \mathrm{~V}$ connected for reverse polarity (DCRP) with the base metal on the negative side of the line. Amperages, based upon electrode diameter, are suggested as follows:

\begin{tabular}{cc}
$\begin{array}{c}\text { Electrode dianeter } \\
\text { (in.) }\end{array}$ & Asperages \\
\cline { 1 - 1 } $3 / 32$ & $85-100$ \\
$1 / 8$ & $110-140$ \\
$5 / 32$ & $130-185$
\end{tabular}

\section{Repair zone}

For preheating purposes, each repair zone of the vessel shall consist of the cavity plus a region around the cavity lying beneath the area circumscribed by a line on the outside surface a minfmum distance of 3T* from the boundary of the cavity. For inspection purposes the repair zone of the vessel shall consist of the regions specifled above for the vessel, except the distance there specified shall be $1 \mathrm{~T} . \star \star$

\footnotetext{
*nT méans n times the wall thickness.

** This is a deviacion from the Code, which requires an examination of a $3 T$ band.
} 


\section{Instrumentation}

Therwocouples and recording instruments shall be used to monitor the preheat, gouging, grinding, welding, and final postweld heat treatment operations. Therwocouples may be attached by velding where practicable.

\section{Cavity preparation and cleaning}

The cavity for the vessel repair, except for the longitudinal boundary for the heat-affected zone flaw, may be partially forned by flane cutting and/or air-arc gouging to rougi dimensions and grinding to finished dimensions. Finished dimensions are shown in Fig. A.2 for the vessel. The repair zone shall be preheated and maintained at temperatures in the range of $350^{\circ} \mathrm{F}$ to $400^{\circ} \mathrm{F}$ until flame or arc cutting and grinding are finished.* After such cutting is completed, a layer of metal under the cut area a minimum of $1 / 4$ in. ceep shall be rewoved by grinding.

Note: The vessel's longitudinal cavity surfaces have been premilled by UCC-ND to establish $f$ inal and optimum planes for subsequent postweld repair heat-affected zone flaw preparations. These longitudinal surfaces shall not be ground. The layout for gouging the top and bottom cavity boundaries wust allow for 1/4-in. post-gouge grinding and the bleiting of ground ends to the premachined middle section. Care should be exercised in cavity corners to retain minimum radii as show in Figs. A.2 and A. 3 . Care must also be taken to preserve the preground longitudinal sides.

The V-7B cavity for the procedure qualification prolongation shall be formed by the fabricator entirely by air-arc gouging and grinding. The cavity shall be centered about the center lines now scribed to the vessel's outer surface. Cavicy end angles must match the angles of the vessel repair cavity ends. Dimensions shown in Fig. A.3 are finished (final ground) dimensions.

The $V-8$ repair cavicy for the same prolongation (shown in Fig. A.4) will be furnished to the fabricator premachined and ready for half-bead technique welding.

*This is a deviation from the Code which does not allow flame (therma1) cutting (with agreement of the Advisory Task Group on Weld Repair for Pressure Vessels; PVRC, At lanta Meeting 6/6/76). 


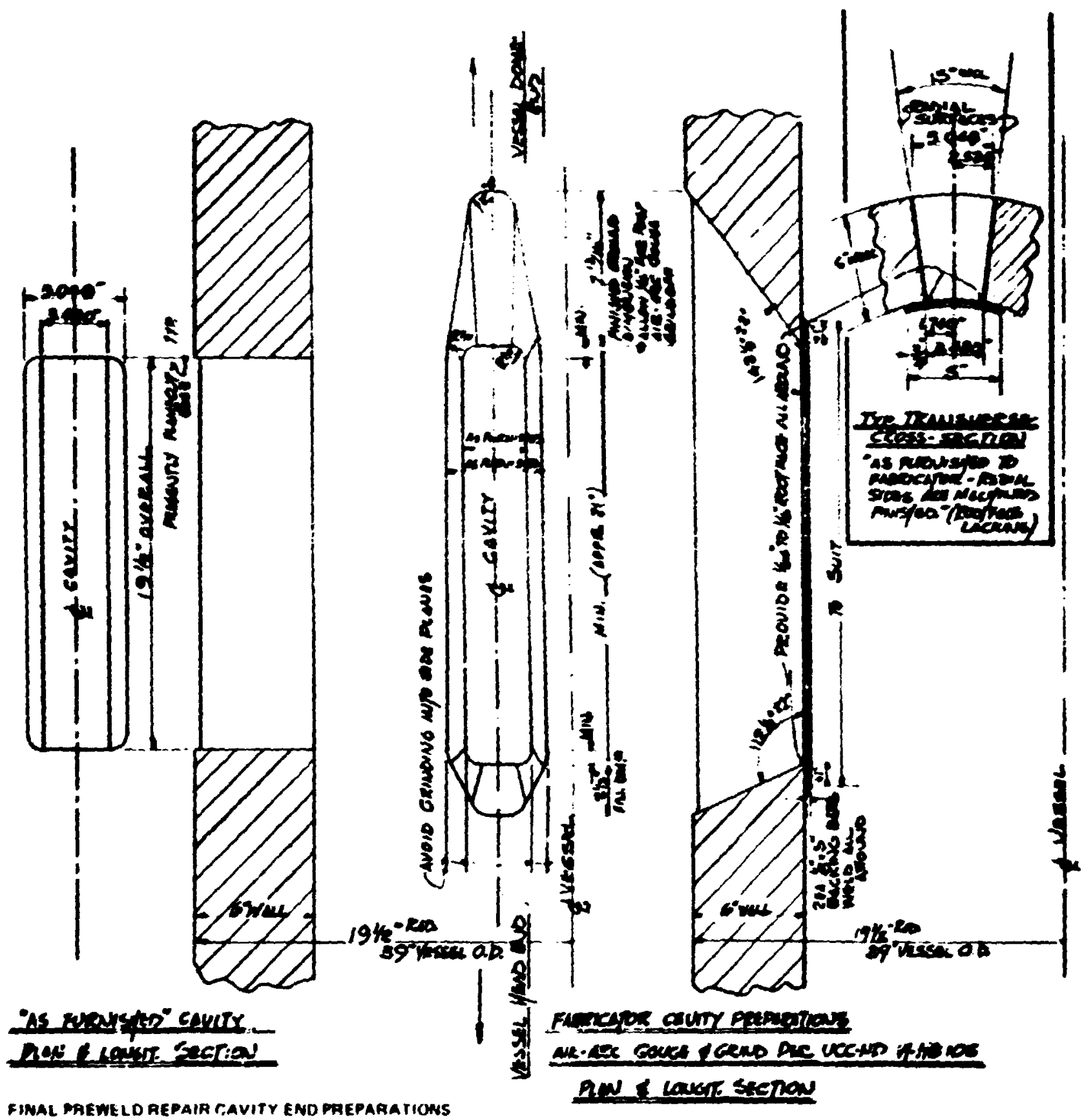

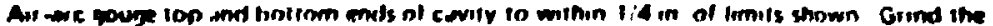

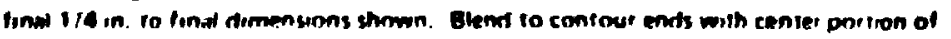

covity. Rashus corners is inhealed

Arrach berking pldies

Prowkte bucking plate terating supports (Not shown)

F1g. A.2. IVT-7B red 
BLANK PAGE 


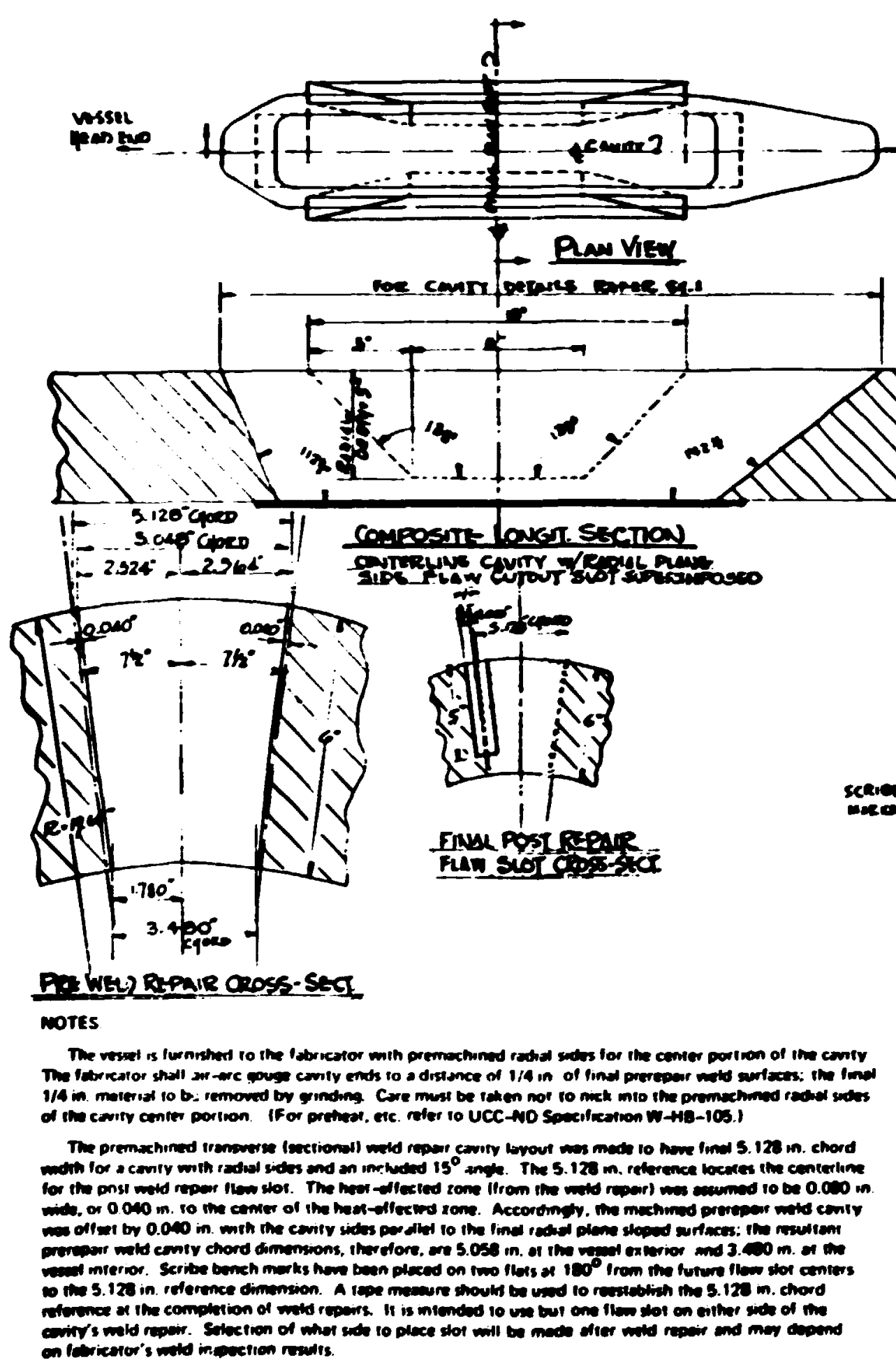




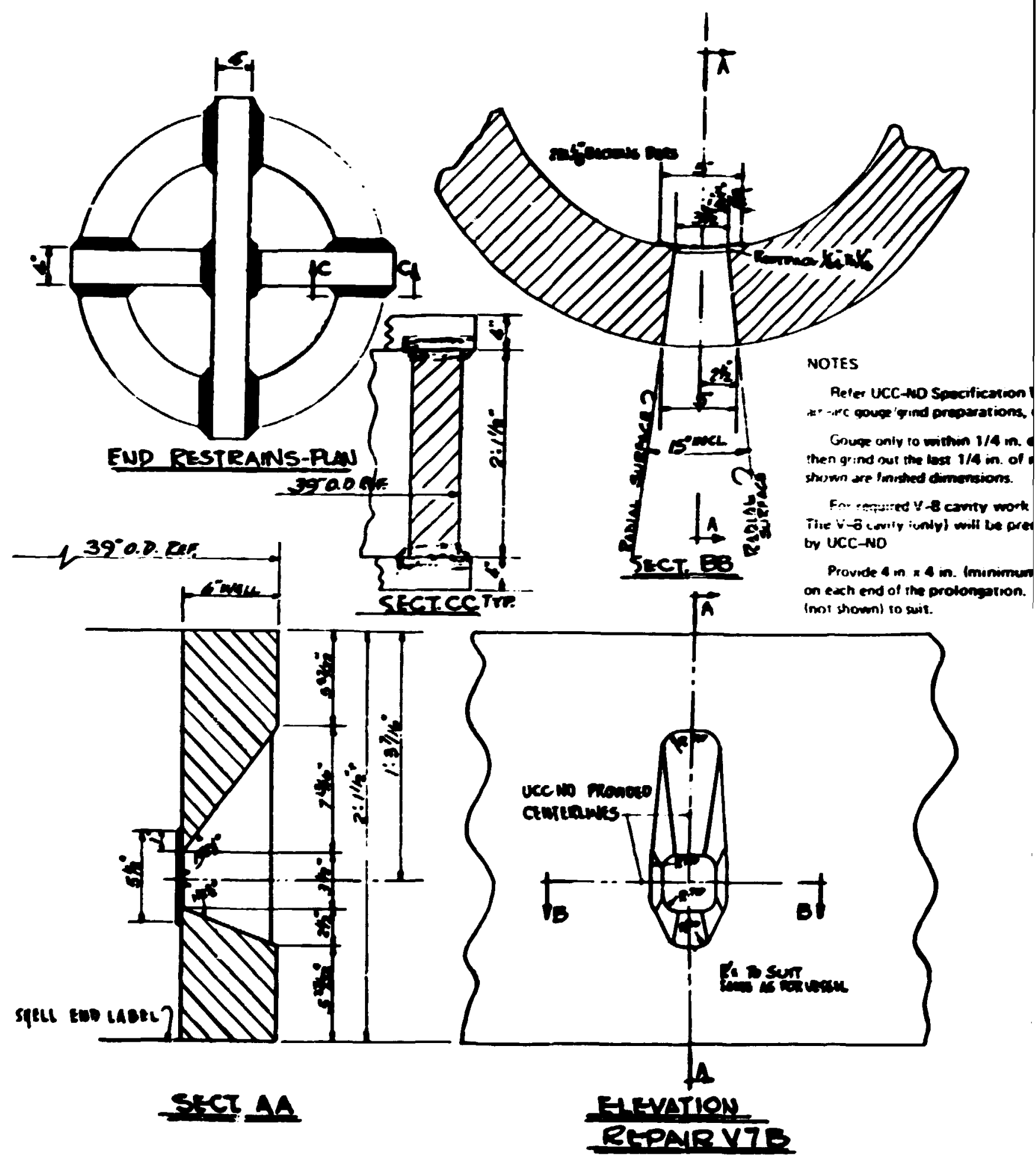

F18. A.3. Weld procedure, prolongation V-10. Detalls for V-71 pair weld. 


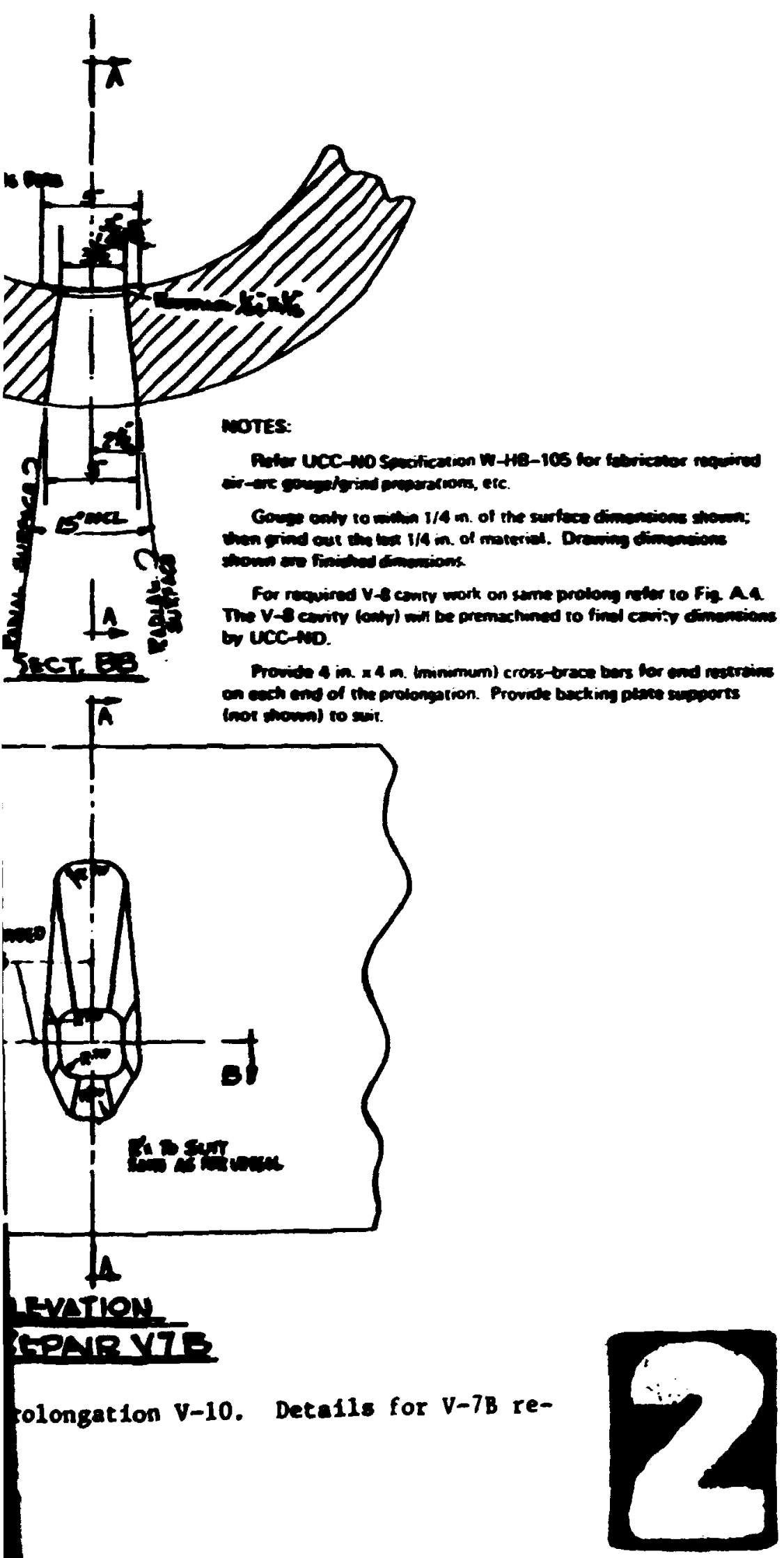


BLANK PAGE 


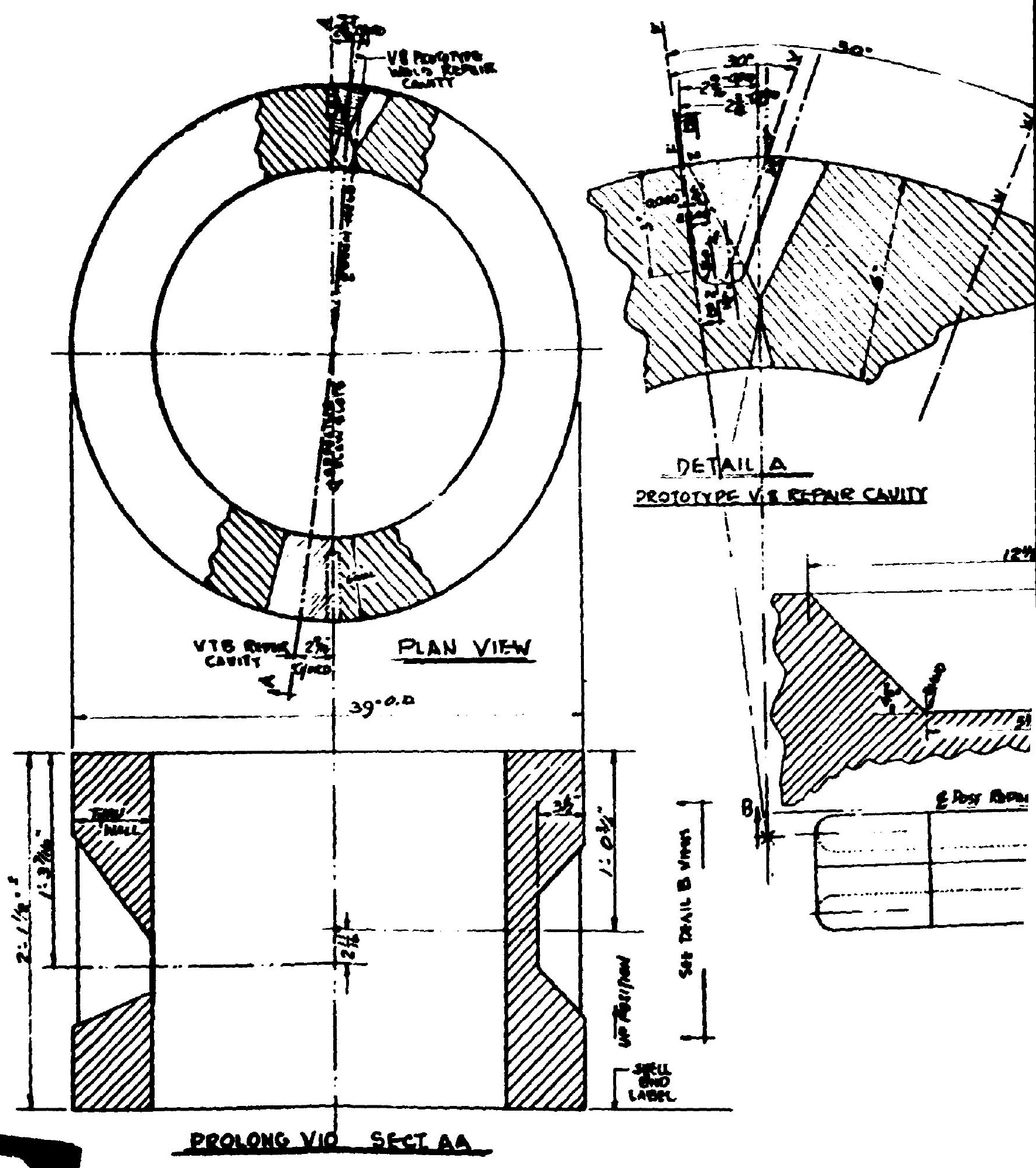

Fig. A.4. The V-8 repatr cavit 


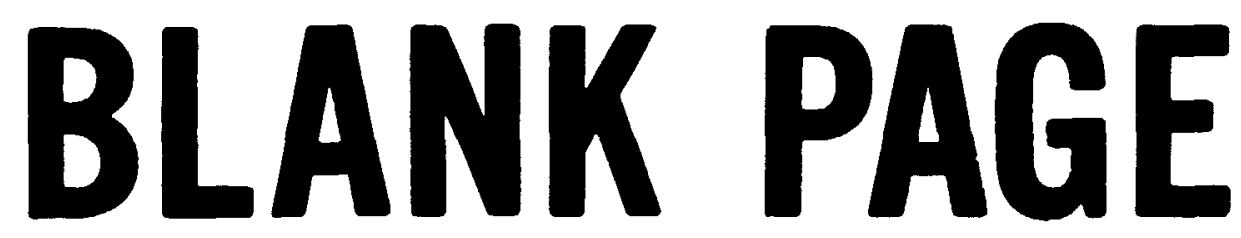


4

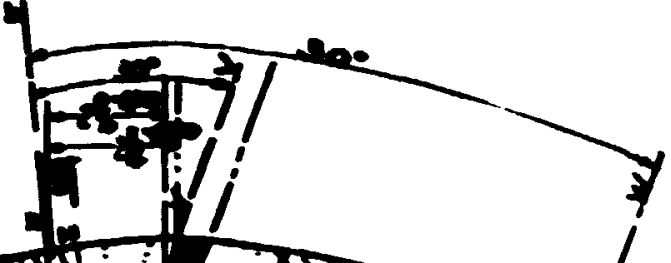

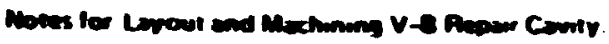

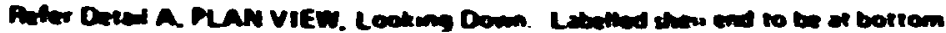

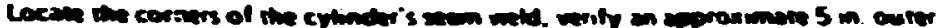

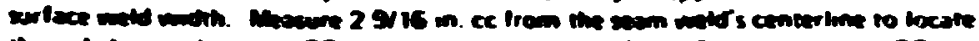

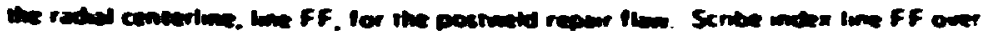

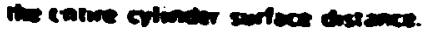

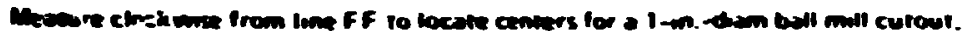

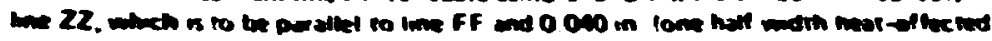

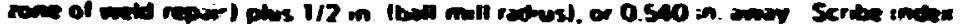
$\ln$.

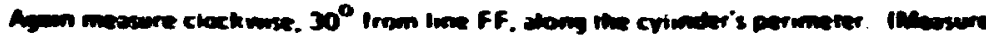

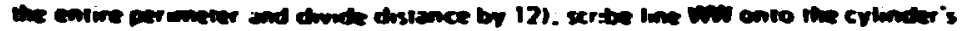

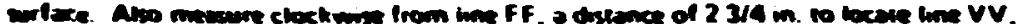

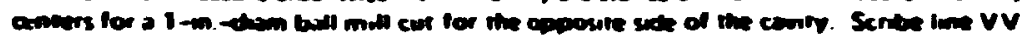

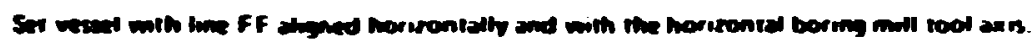

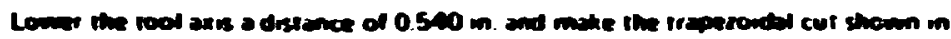

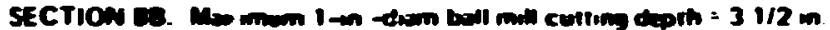

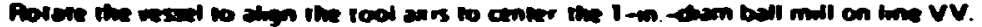

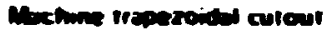

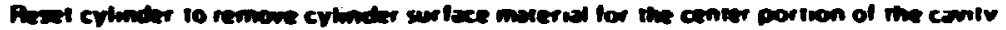
houd grind as nevereary to bind contowrs andfor cormen.

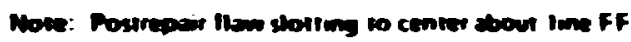

\section{peroments reacening}

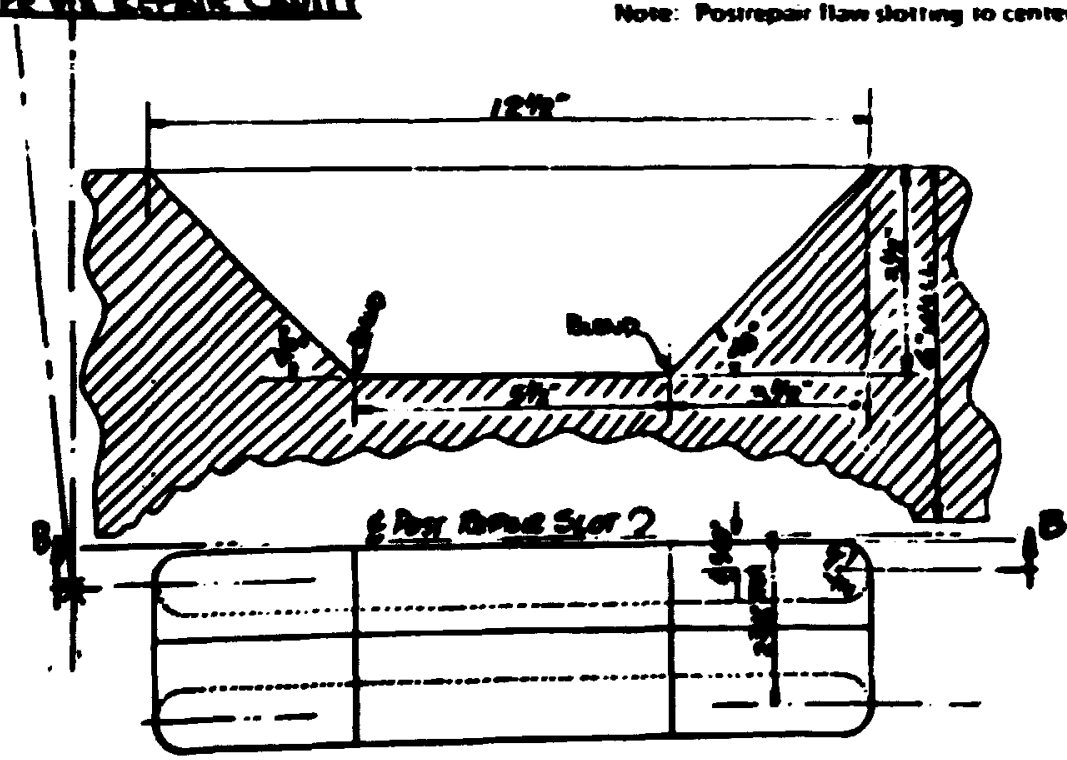

718. A.4. The V-3 repait cavity. 
Detailed procedures for cavity prefaration and cleaning as prepared previously shall be kept and adhered :0 at the job site.

In Iinal preparation for welding, the cavity shall be ground smooth and clean, except as noted above, with beveled sides and edges slightly rounded to provide suitable accessibility for welding. The surfaces within IT distances of the joint shall be cleaned of all dirt, cil, grease, paint, and excessive amounts of scale and rust. The cavities of the vessel and test pieces shall be exanined by magnetic particle inspection in accordance with the requirements of IWA-2221 prior to welding. Additional grinding shall be perforwed with preheat as necessary to rewove indications of flaws. Actual dinensions and location of the cavity shall be documented.

\section{Care of welding electrodes}

The moisture content in the protective coating of the low-hydrogen electrodes shall not exceed $0.6 \%$, by weight. The folluwing steps shall be taken to prevent molsture pickup, except minor deviations may be allowed with prior writcen approval of JCC-ND.

All coated electrodes shall have been baked before use at temperatures of $800^{\circ} \mathrm{F}=25^{\circ} \mathrm{F}$ for $30 \mathrm{~min}$ co $1 \mathrm{hr}$. The temperature of the oven shall be $300^{\circ} \mathrm{F}$ or lower when the electrodes are placed in the oven for baking. During the baking cycle, the cemperature shall not be raised more than $300^{\circ} \mathrm{F} / \mathrm{hr}$ when oven temperatures are $a b \partial v e 500^{\circ} \mathrm{F}$, and the total time above $500^{\circ} \mathrm{F}$ shall not exceed $5 \mathrm{hr}$. After baking, and before the electrodes are allowed to cool below $150^{\circ} \mathrm{F}$, they shall be repackaged in sealed container: The fabricator shall record and report wiscure levels of each batch of electrodes. Electrodes shall not be rebaked wore than once.

During the repair, the electrodes shall be removed from their sealed containers and thereafter kept in portable heated ovens which shall be at the work station. These ovens shall be at 225 to $300^{\circ} \mathrm{F}$. Electrodes shall not be out of an oven wore than 20 min prior to use. Electrodes not used within $20 \mathrm{~min}$ after rewoval from the oven shell be returned to the holding oven and held at 225 to $300^{\circ} \mathrm{F}$ for at least $8 \mathrm{hr}$ before re1ssue. Random wolsture contents rechecks should be conducted at lenst once a day on electrodes of rach size in use and on those taken from the 
portable heater ovens at the welder worix stations. The fabricator shall inftiate and aintafn records to indicate conformace to the above electrode bakeout and rod issuance regulations.

All electrode end conditions should be inspected carefully before use. The sall diamers electrodes are litely to hwe the flux coatine chipped of at the start end. Electrode ends should be exanined three cines: (1) when the electrode is rebalted, (2) when the vacun package is opened, and (3) when the electrode is caken from the electrode holdins oven by the welder. Electrodes must be rejected whenever there are any signs of cracks in the flux couting.

Detalled fabricator procedures for the care of electrodes nust be forwarded to UCC-ND for witcen approval within one week after contract award. Upon approval, these procedures shall be hept and adtered to at the job sice.

\section{Conditions for velding}

The prolongation, vessel, and test coupons shall all be edequately braced to prevent warpage. Test pieces shall be restrained to avold warpage and to sinulate the restraint of the veasel. Backins plates shall be installed before anchoring or braclag. Backing plates chall consist of two layers of precontoured standard fabricator steel backing naterial. Flat test pieces shall be anchored to heavy eupport plates or welding tables. All work wust be vertically positioned for all welding.

All subcequent repair work shall be performed with prehent appliad to the bace naterial. The preheat ceaperature in the repair zone shall be within the temperature range of 350 to $500^{\circ} \mathrm{F}$. The temperature shall not be allowed to fall below $350^{\circ} \mathrm{F}$ until the completion of either an Iaternadiate postmild hat treatment (Min)* of 450 to $550^{\circ} \mathrm{P}$ for $1 / 2 \mathrm{hr}$ or after a final purr at the suse temperatures for $4 \mathrm{hr}$. If electrical heat is used, stendby torches shall be provided to anitain vessel teimperature or perfor en internediate Fitir in case of prolonged power outages or unanticipated equipunt alfunctions. A magnetic particle test of the wid cavity would be required following ang internediate Filix.

\footnotetext{
Puir accually infers a postwid tempertas trentent only.
} 
10. Position of welding

All welding shall be doac with the longitudianal axis of the vesecel and/or prolongation or test piece is the vertical position. For the halfbead pass and at least the first pass thereafter, welding shall be in the vertical position for the cavity sides.

\section{Weld estal deposition}

Welding shall be done in general eccordance with the illustrations of Fis. A.5.

The cavity shall be butcered using 3/32-in.-maxima-dian electrodes as show in Step I, A.5. Approxinately one-half the chichess of this butcering lajer shall be removed by grinding before depositing a arcond layer. Special procedures shall be established as aceded to control the grinding of the buttering layer. Such procedures ary aploy the use of corkanship spectens, dineasionsl ceasureneats, or ocher means to dewonscrace compliance. The axisu interpass temperature shall be held to $500^{\circ} \mathrm{F}$. See Step 2. The second layer shall be deposited with either 1/81n.- or 5/32-in.-dia electrodes. The maxima bed width shall not exceed four times the electrode core diemeter. Bead posftioning shall be performed in a manner to temper the prior beads and their heat-affected zones as shown in Step 3 of Fis. A.5. The completed weld shall have at least one layer of weld reinforcenent (crown pass) deposted. This final layer should overlap, but shell not extead beyond the buttering depostt of the firet pass. This reinforcenent shall chereafter be rewoved by grinding, waking the fintshed surface of the repalr oubstantially flush wth the surfece of the veasel surrounding the repair. Likentee followIng all welding and the postheat and cooldown, the becking plate shall be renoved, and the interfor repair surface shall be costoured evenly to

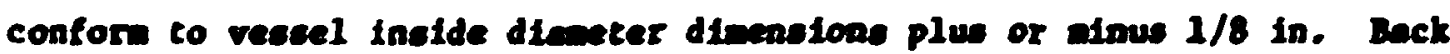
welding nay be roquired to satisfy this requitenent. UCC-id wlll be notifled prior to and shall approve any beck welding operations. Teaperbead techatques ney again be required.

Possible benefice of controlled peantag, as pervitted by section XI, shall not be cvaluet in this wald repatr. 


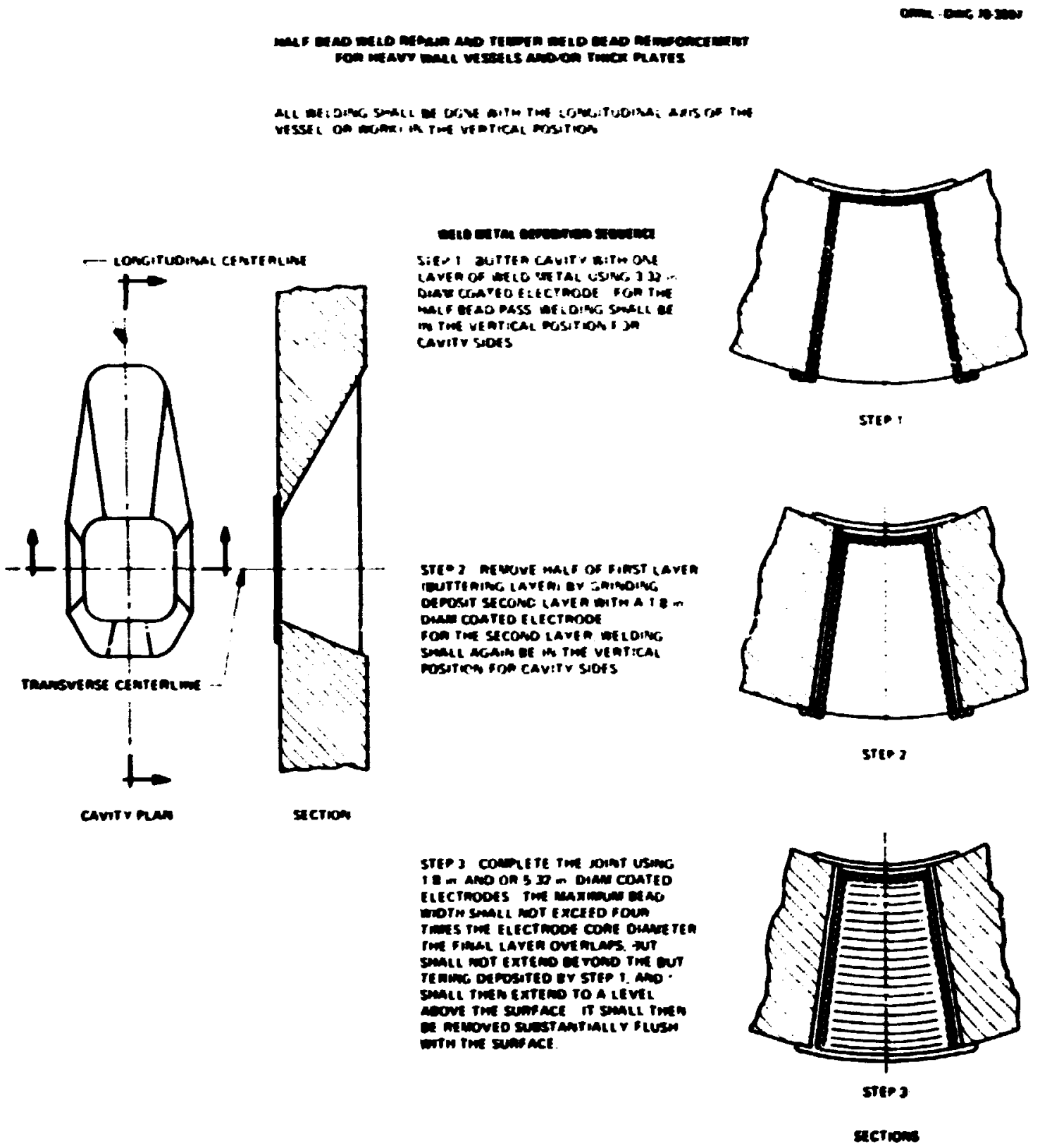

P18. A.S. Ha1f-bead weld repeit sequence.

Detalled procedures for grinding and controlling the thickness of the buttering layer and, if elected, controlled peening shall be kept at the job site during this part of the work. Utwost care should be exercised to grind off approxtately half of the buttering layer as dimenstonal vertf1c: - 100 by measurcant is extramely difficult in a covity at approximately $400^{\circ} \mathrm{r}$. 
12. Inspection during velding (vessel and both prolonetion welds)

A asgotic particle examination (II) shall be perforned on the ground butcered layer, the next 1/8-in. layer, and chereafter on alcerance layers and the final ground outside surface. * The final it shall be completed prior to ihe start of the 4-hr postweld heat treatent. Layers not inspected by MT shall be visually inspected. Where necessary, weld defects shall be renoved and the repaired zone reinspected. If defects occur vithin $3 / 16$ in. of the base metal, such repairs shall be fide using the butcering and half-bead grinding techaique. An Mr exalination shall be perforned on the vessel ID after grinding and beckaclding (if required). MT Indications shall be renoved by grinding and bleading and a abeaquent MT exanination shall be ade to ensure resoval of defects.

\section{Postweld nondestructive inspection (vessel and both prolongation welds)}

The repair zone as defined above under Repair zone shall be nondestructively exanined after the completed weld has been at ablent cenperature for a period of not less than $48 \mathrm{hr}$. A voluetric exanination of the repair zone shall be ade by radiography in accordance wich $\mathrm{Nu}$ 2231 and ultrasonic exenination in accordance with IWA-2232, eacept that calibration block material of the yame specification as the base anterial shall be deewed to weet the requirement of paragraph I-3121. A magnetic particle exomination in accordance with IWA-2221 shall be ade of the surfaces of the repair zone and of areas representing locations of weld atcachents. A vicual exeotacion shall be ande in accordance with IU2210.

Acceptance of the repaired vessel shall be decernined in accordance with IW-3500 and exeatination category B-A. If necessaty, repalrs of the repatr zone of the veseel shall be ende in accordance with the half-bead weld cechnique as described in the foregoing sections of Part $I$.

"Th1s deviates fron the Code, which calls for exenining every layer (with agrecient of the Advisory Task Group on Weld Repalr for Pressure Veseels, PVIC, Atlanta Meting, 6/6/75). 


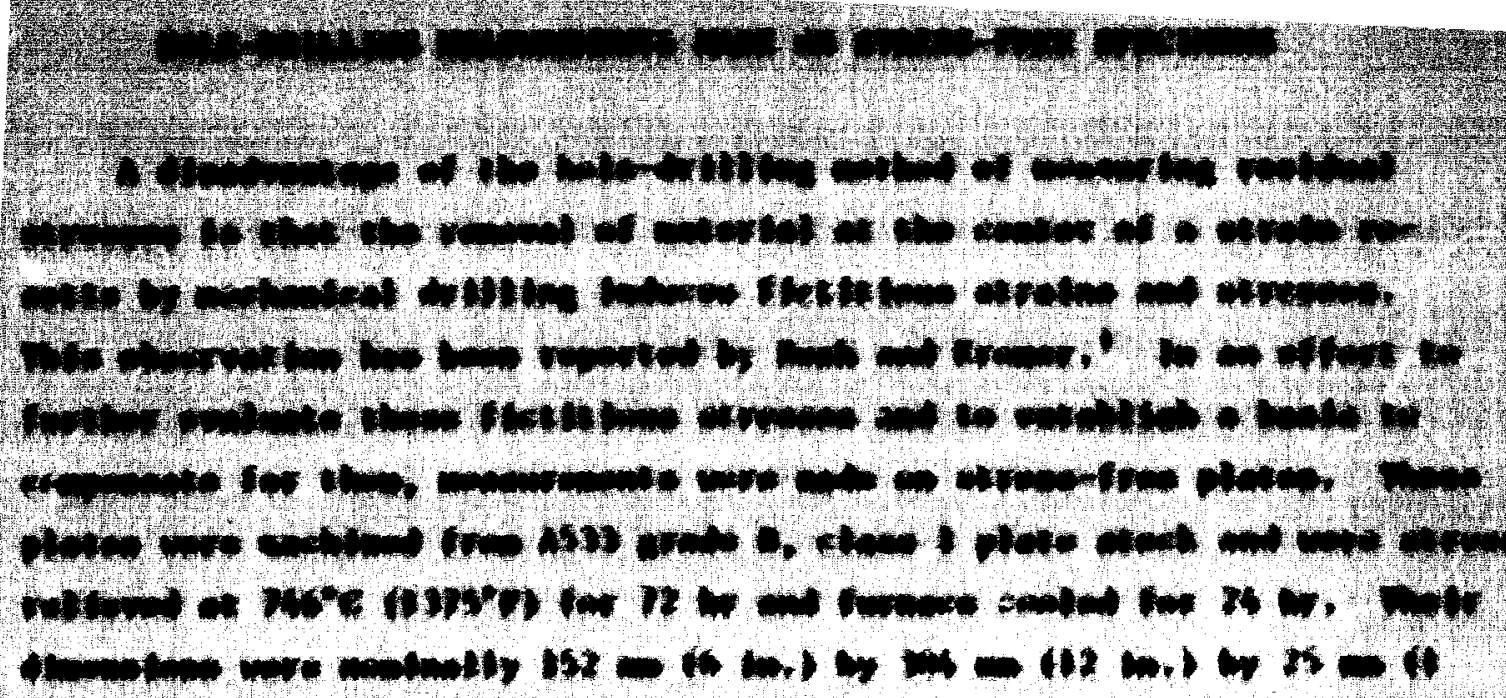

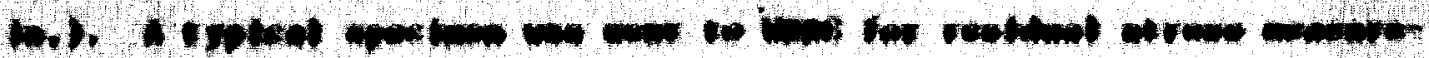

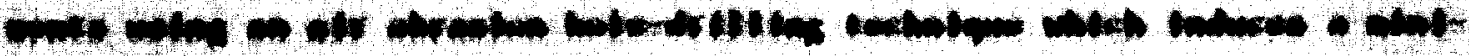

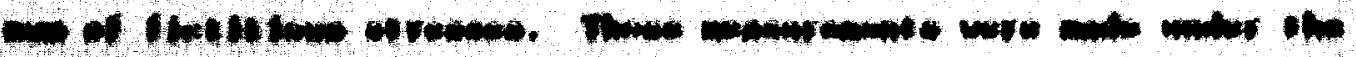

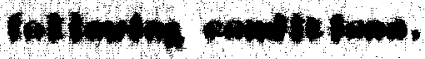

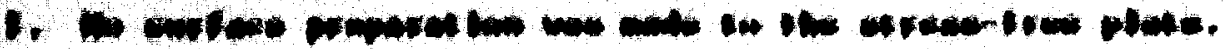

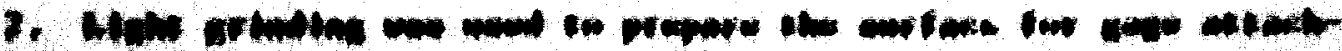
nement.

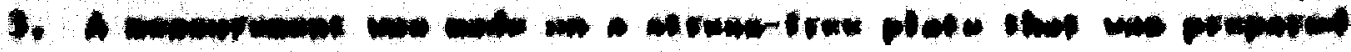
or neme.

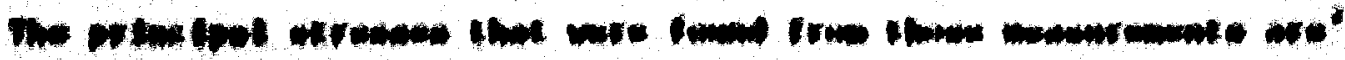

\begin{tabular}{|c|c|c|}
\hline ? & $\begin{array}{l}2,4(6,6) \\
13,2(5,1) \\
4,4(6,3)\end{array}$ & 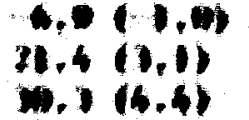 \\
\hline
\end{tabular}

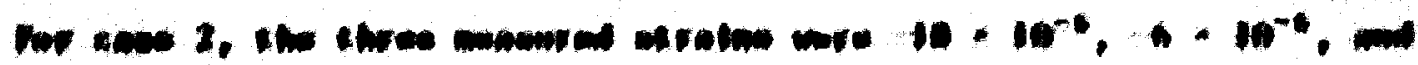
th * in".

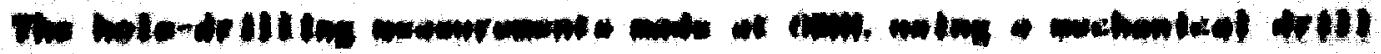

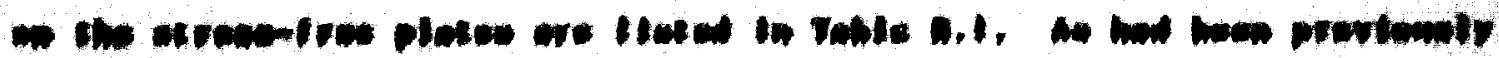

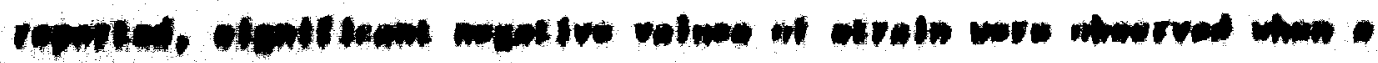

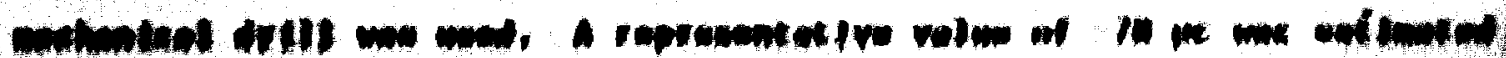




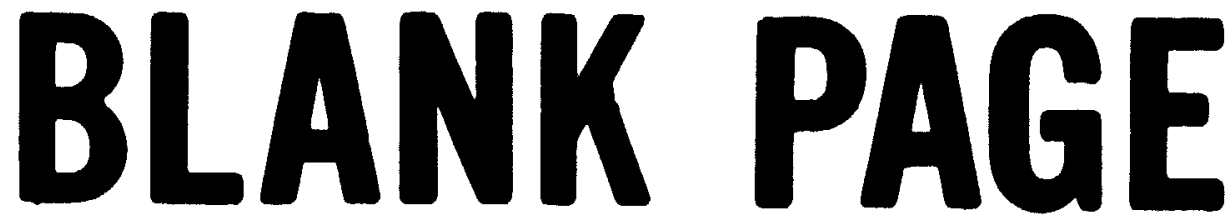


table B.1. Calculized primipal stresses froe mole-drillias erasuremeats (mexhenical drill) ra a stress-f ree plote

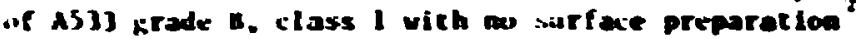

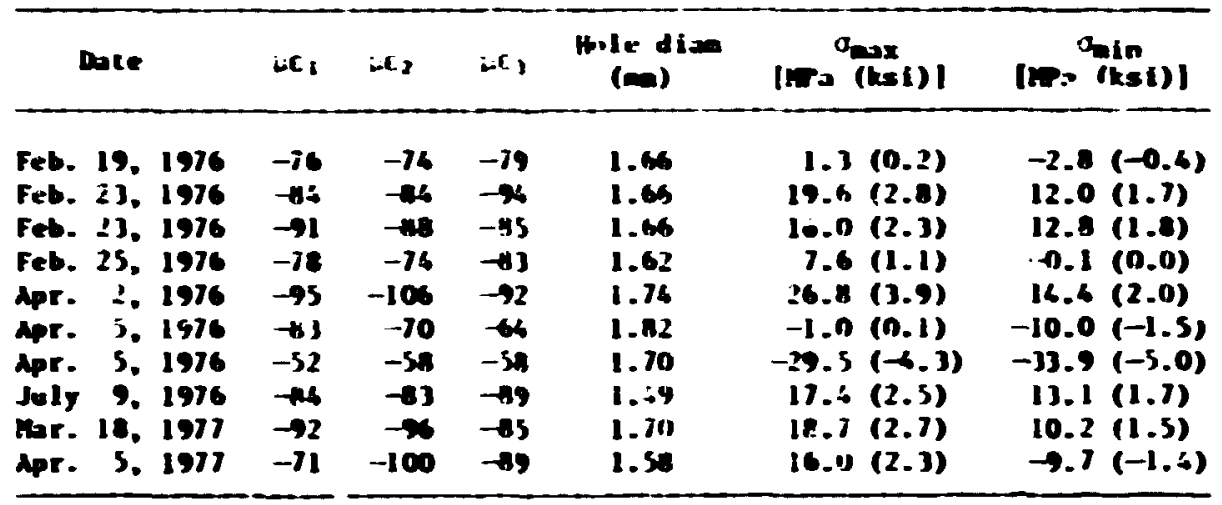

IA correction of 70 tet was ded to each rmorded se raia.

from the data listed in Table B.l and that value of strain with the sign changed was used as a compensation in all hole-drillins type stress calculations reported here. Using the adjusted values, the principal stresses, $\sigma_{\max }$ and $\sigma_{\text {min }}$ were then calculated using the procedure deacribed in Chapter 4. The principal stresses caused by hole drilling are also listed in Table B.1 and provide an indicatio., of the scatter that can be expected. Al of the hole-drilling induced stresses reported in the appendix have been calculated after an adjustment of 78 uc. Sinilar data for weld metal that was cut from the V-7B weld repair simulation and then thermally stress relleved are listed in Table B.2.

In order to make through-thickneas residual stress measurcinents, it was necessary to sow the simulation welds along plenes of interest as shown In Fig. 5.1. A typical seving operation is show in Fig. 5.2. Swing, like any other achining operation, induces residual stresees very cloce to the achined eurface. If macureants wre taken with no spectal precautions, misleading through-thickness wasurenents could result. In order to elininate the umanted surface effecte resultias from andag, various surface renoval echenes mere amployed. Results of a study of the gentle frind eathod of anterial ranoval are presented in Ref. 3. The principal conclusion of that work wes that if euffictent coolant and slow feed rates are used, then atolan okin effects on restdual stress masuremente result. A gentle grind procedure, listed in Table B.3, was ueed to prepare 
Table B.2. Calculated principal streses fron hole-drilling (Eechanical drill) on a streas-free specinen of weld netal

\begin{tabular}{|c|c|c|c|c|c|c|}
\hline Dete & $\mu E_{1}$ & $\mu E_{2}$ & $u_{3}$ & $\begin{array}{l}\text { Hole dim } \\
\text { (m) }\end{array}$ & {$\left[\operatorname{tep}{ }^{\sigma}(\operatorname{mex} 1)\right]$} & {$\left[\ln a^{\sigma_{\min }}(\ln 1)\right]$} \\
\hline $\begin{array}{l}\operatorname{my} 13,1977 \\
\text { May 13, } 1977 \\
\text { Sept. 8, } 1977\end{array}$ & $\begin{array}{l}-63 \\
-43 \\
-50\end{array}$ & $\begin{array}{l}-59 \\
-54 \\
-54\end{array}$ & $\begin{array}{l}-53 \\
-48 \\
-41\end{array}$ & $\begin{array}{l}1.53 \\
1.62 \\
1.78\end{array}$ & $\begin{array}{l}-29.8(-4.3) \\
-47.3(-6.9) \\
-36.3(-5.3)\end{array}$ & $\begin{array}{l}-35.9(-5.2) \\
-50.1(-7.3) \\
-4.2(-6.4)\end{array}$ \\
\hline
\end{tabular}

a spection of weld watal wo cut frow the V-7B staulacion repair weld and thernally streas relieved. A correction of 78 we was added to each recorded serala.

Table B.3. Procedure ised to prepare the surfaces of the V-7A specinea for chrough-thickness measurenents

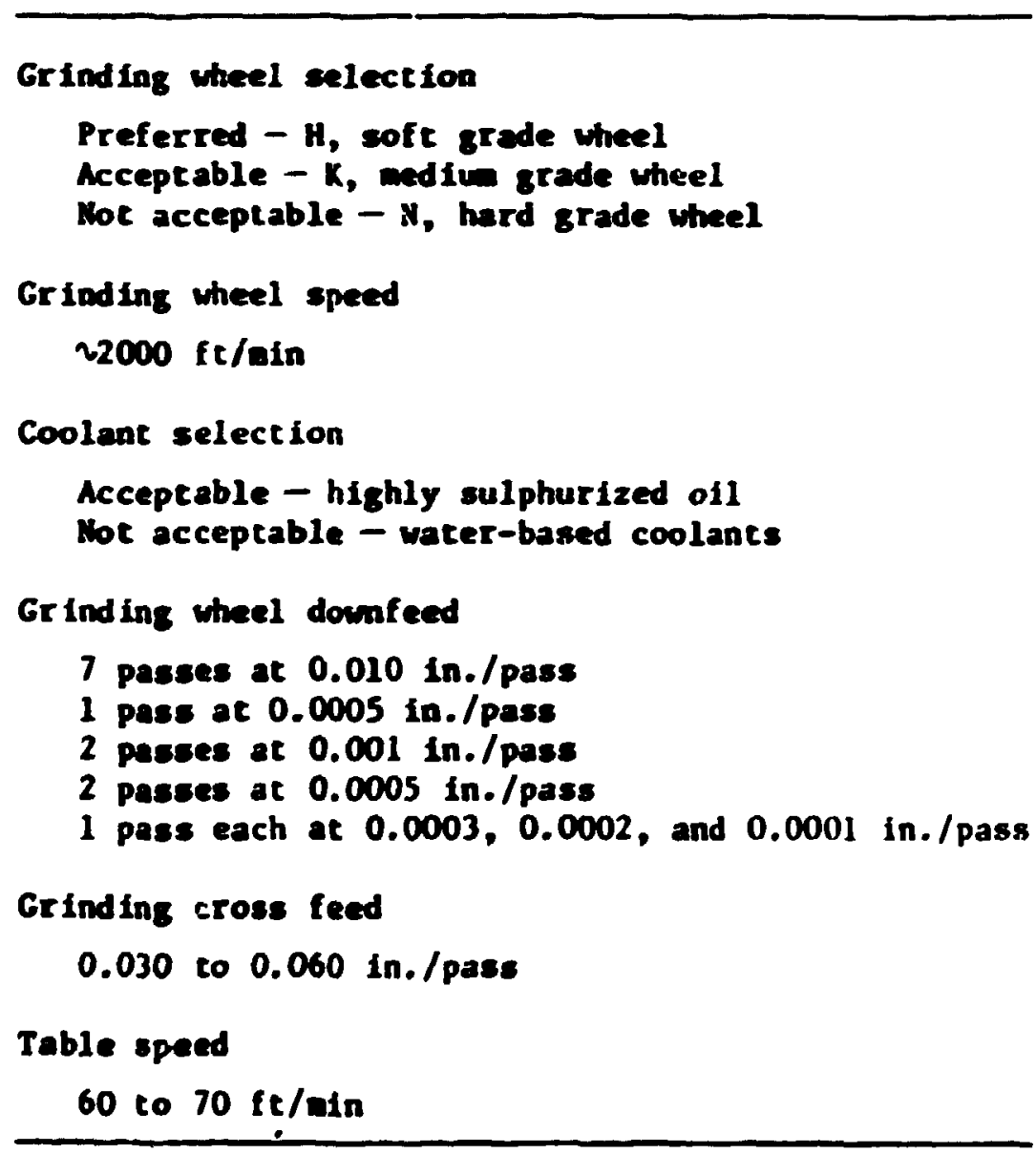


the surfeces of the V-7A simation weld sections thoun in Figs. 4.1 and 5.6. Since the procedure that was used was very close to the reconneaded and researelud ecthod, wo further studies of it vere ande.

The previously devertbed geacle frind ectud of preparing a surface wo sutitable, providing that the spaction to be grown did not excend the size and weight linitations of the avellable grinders. For the epecten shown in Fig. 4.2 and the V-8 vescel shown in Fis. F.1, the velght support

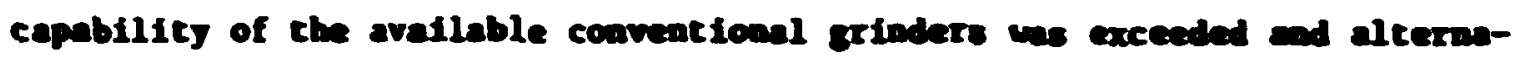
tive procedures were developed and coninad. The eatire through-ehichones surface of the specinen show in Fis. 4.2 wa given a gentle grind using - Blenchard grioder. The specification used for this operacion is preceated in Table B.4. Residual streas mesuramente taken from strese-free plates of $A 533$ grade B, class 1 thet had received the grinding described by Table B.4 are given in Table B.5. These deta compred favorably with that of the stress-free plate data given in Table B.1.

Table B.4. Specification for grinding the V-8/V-7B simulation repair wld specinen used for through-ehickneses aresidusl stress exasuremencs

$$
\begin{aligned}
& \text { Grinding stones } \\
& \text { Norton } 23424-F 12 \text { ven } \\
& \text { Dormfeed } \\
& 8 \mathrm{mils} / \mathrm{min} \text { for } 100 \mathrm{mils} \\
& 4 \mathrm{mils} / \mathrm{min} \text { for } 150 \mathrm{atls}
\end{aligned}
$$

Table speed

11.9 rpm

Griading wheel speed

$350 \mathrm{rpm}$

Maxima coolane flow

$$
a_{\text {see 118. } 4.2 .}
$$


Table B.5. Calculated principal streses froe hole-drilliag enasurements (echanical drill) that were ade on a strese-free plate thyt had been given the surface preperation listed in Table B. $4^{4}$

\begin{tabular}{|c|c|c|c|c|c|c|}
\hline Date & $u \varepsilon_{1}$ & $\boldsymbol{u \varepsilon}_{2}$ & $u_{C_{3}}$ & $\begin{array}{l}\text { Dole diam } \\
\text { (a) }\end{array}$ & {$\left[\operatorname{lima} a^{a}(\operatorname{tat} 1)\right]$} & {$\left[\operatorname{lea} \operatorname{ain}_{(\operatorname{le} 1)}\right]$} \\
\hline $\begin{array}{r}\text { Mer. 18, } 1977 \\
\text { Apr. 4, } 1977\end{array}$ & $\begin{array}{l}-83 \\
-60\end{array}$ & $\begin{array}{l}-75 \\
-80\end{array}$ & $\begin{array}{l}-77 \\
-66\end{array}$ & $\begin{array}{l}1.56 \\
1.72\end{array}$ & $\begin{aligned} 6.2 & (0.9) \\
-1.6 & (-1.2)\end{aligned}$ & $\begin{aligned}-1.2 & (0.0) \\
-11.1 & (-1.5)\end{aligned}$ \\
\hline
\end{tabular}

\section{Defereaces}

1. A. J. Wush and F. J. Kromer, "simplification of the Hole-Drilling Hethod of Residual stress thasurements," ISA Troms. 12(3), 249-259 (1973).

2. Telephone comonication from A. J. Dush, Hay 12, 1976.

3. L. J. Nowtkouski, J. Mranchik, Jr., and M. Field, "Discortinn and Residual Surface Stress in Grinding and Hiling of High Serongth steels," 1961 SuE Metional Meronautics Heeting, Kew York, 340L. 


\section{Appendix $C$ \\ V-7 SERIES REPAIR WELDS - MELDABLE STRAIR GAGE MEASUREIESTS}

Appendix $C$ contains the veldable strain gage data for the $1-7 A, V-i d$ simulation, $V-7 B$, and $V-7 B$ simulation repair velds. Chapter 4 contains a discussion relatiog to the weldable gage measurements.

Figure $C .1$ shows the coordinate systes used to refertace cencerpoints of the weldable strain gages for the $V-7 A$ simulation repair veld (Table C.1) and the centerpolnts of the weldable strain gages for the V-7A repait we!d (Table C. 2 ;. The paoes that are listed in each of those tables are Idene if ted by a number and are simun to scale relative to the weld cavity outlines as seen from vutaide the $V-7$ prolongat ton and the $V-7$ vessel in Figs. C. 2 and C.3. The total changes in strain, LuE in the tablea, were deternined by zeroing the gages at room temperature fust prior to heatup for che weld repair and then recording the strain upon completion of che weld repair and after the prolongation and vessel had been brought back ro the nominal roun ceaperature. In the case of the V-TA repatr weld, che cotal strain weasurement was wade af cer the end braces were rewoved. The amount of strain change that occu:red as a result of rewoving the end braces is listed in Table $C .1$ as $\Delta \mu E^{\star}$. For those strain measurement locations where large residual stresses were recorded, (e.g., locat lons $3 A, 4 A, 5,7 A$, and $B A$ ) the strain change as a result of removing the braces is relatively sall. The elapsed tiwe over which the strain luck was measured was neerly $41 / 2 \mathrm{hr}$, and the nine therwocouples to the prolongation showed an average increase of $5.6 \mathrm{~K}\left(10^{\circ} \mathrm{R}\right)$. It would therefore appear that the end braces were not a significant factor in the residual stress Cleld that developed in the V-9 prolongation as a result of the V-7A simlation repair weld. The stressed $(\sigma)$ that are listed in Table C.1 and C.2 are shom in FIgs. C.4 and C.5 relative to the weld cavity outilne where the weld cavity and the wold lines indicating gages are drem to scale. The seresses were calculated by the methods described in Chapeer 4.

Figure C.6 show the coordinete system uned to reference centerpotncs of the weldable gages for the V-7B simulation rapait weld (Table C.3) and the centerpointe of the weldable etroin gages for the V-7B repatr wid (Toble C.4). The gages that ere lieted in each of those cobles ere 


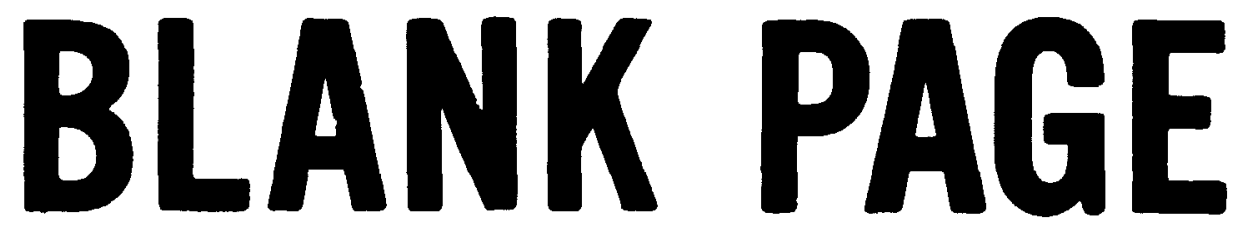




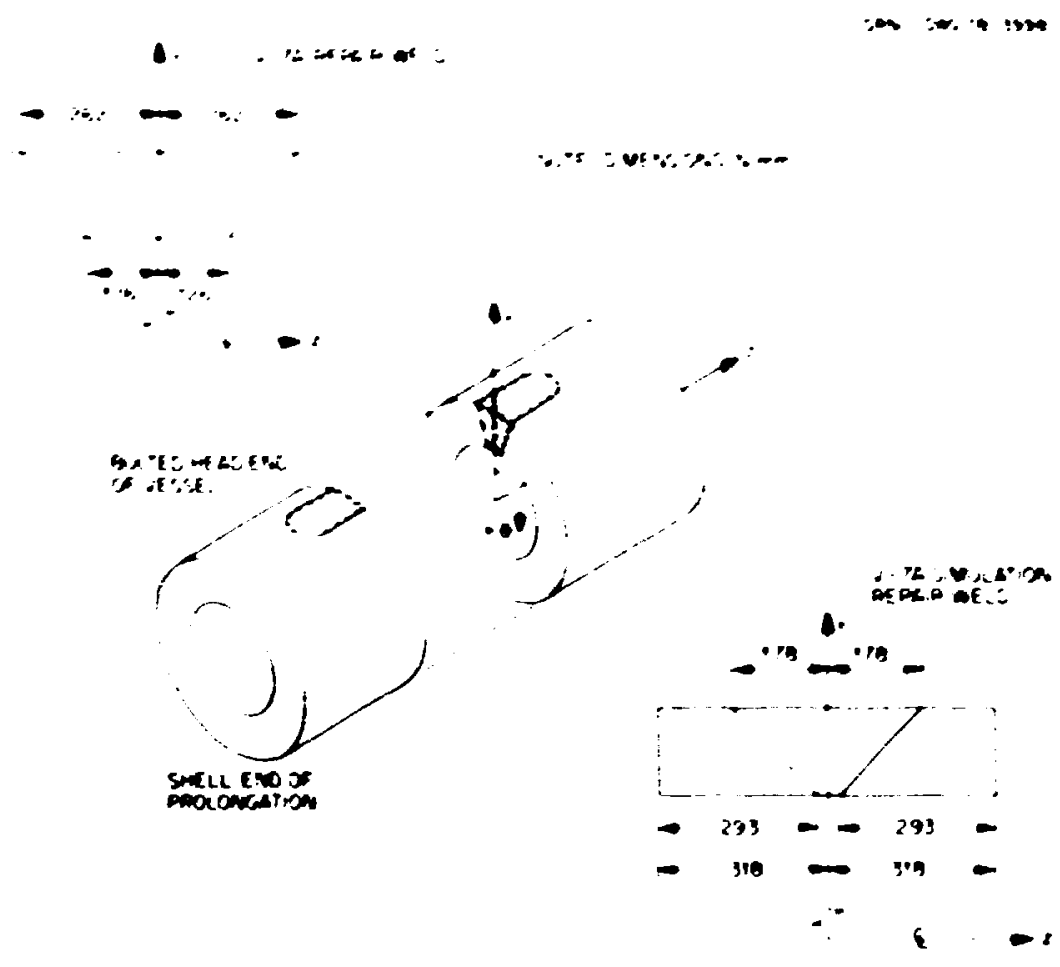

F18. C.1. Coordinate system used to def ine the weldable strain gage locations listed in Tables $C .1$ and $C .2$. The $r z$ and $r \theta$ planes are planes of syemetry for both the V-7A simulation repair weld and the $V-7 A$ repair weld $(100=3.94 \mathrm{in.})$.

0.mon-0un 78-3999
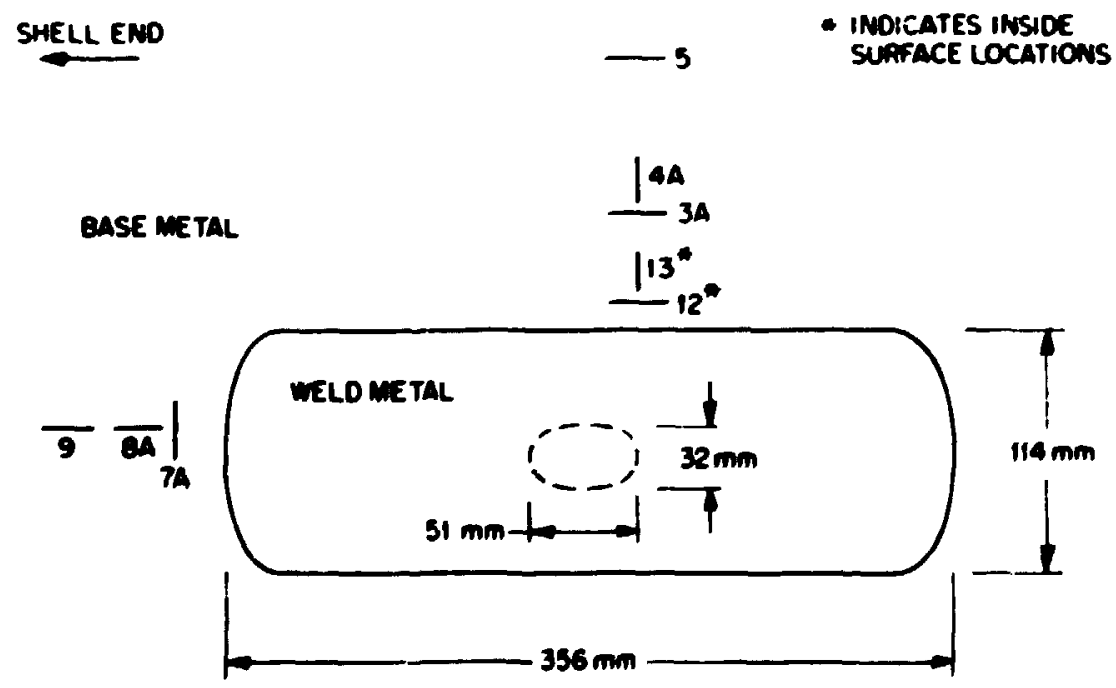

Fig. C.2. Weldable strain gage layout about the V-7A simulation repalr weld $(100 \mathrm{ma}=3.94 \mathrm{In.})$. 
Table C.l. ineldable strain gage results for the l-it sibulation repair weld

\begin{tabular}{|c|c|c|c|c|c|c|c|}
\hline \multirow{2}{*}{$\begin{array}{l}\text { Gage } \\
\text { No. }\end{array}$} & \multicolumn{3}{|c|}{ Coordinates: } & \multirow{2}{*}{$\begin{array}{c}\text { sue } \\
(\operatorname{cotal})\end{array}$} & \multirow{2}{*}{$\begin{array}{c}0 \\
\text { (MPa) }\end{array}$} & \multirow{2}{*}{$\underset{\text { Gage }}{\text { orientat ion }}$} & \multirow{2}{*}{ SUE* ${ }^{C}$} \\
\hline & $\underset{(\mathrm{mm})}{r}$ & $\begin{array}{c}\theta \\
\text { (deg) }\end{array}$ & $\stackrel{2}{(\operatorname{mos})}$ & & & & \\
\hline $3 A$ & 508 & 12.2 & 0 & -1063 & -151 & $\boldsymbol{A}$ & 40 \\
\hline iA & 508 & 13.9 & 0 & 1278 & 212 & C & -161 \\
\hline 5 & 508 & 20.8 & 0 & -725 & -145 & A & 39 \\
\hline $7 A$ & 508 & 0 & -203 & $-i 187$ & -207 & C & -143 \\
\hline $8 A$ & 508 & 0 & -219 & 811 & 102 & $\mathbf{A}$ & 24 \\
\hline 9 & 508 & $\mathbf{0}$ & -254 & 270 & 54 & $\mathbf{A}$ & 101 \\
\hline 12 & 343 & 11.9 & $\mathbf{0}$ & 95 & 24 & $\mathbf{A}$ & 63 \\
\hline 13 & 343 & 14.4 & $\mathbf{0}$ & 43 & 15 & C & -8 \\
\hline 19 & 508 & 180 & 0 & -66 & -13 & $c$ & -80 \\
\hline 20 & 343 & 180 & $\mathbf{0}$ & 215 & 43 & C & 144 \\
\hline
\end{tabular}

coordinates are def ined in Fig. C.l.

$b_{A}$ represents axial and $c$ circueferential.

${ }^{c}$ strain change that occurred as a result of rewoving the end braces.

Table C.2. Heldable strain gage regults for the vessel $v-7 A$ repair weld

\begin{tabular}{|c|c|c|c|c|c|c|}
\hline \multirow{2}{*}{$\begin{array}{l}\text { Gage } \\
\text { No. }\end{array}$} & \multicolumn{3}{|c|}{ Coordinates $^{a}$} & \multirow[b]{2}{*}{ AuE } & \multirow{2}{*}{$\stackrel{\sigma}{(\text { apa) }}$} & \multirow{2}{*}{$\underset{\text { Gage }}{\text { ortentention }}$} \\
\hline & $(m)$ & $\begin{array}{c}\theta \\
\text { (deg) }\end{array}$ & $\stackrel{2}{(m)}$ & & & \\
\hline $\begin{array}{l}3 \\
4 \\
8\end{array}$ & $\begin{array}{l}496 \\
496 \\
496\end{array}$ & $\begin{array}{c}12.2 \\
13.9 \\
0\end{array}$ & $\begin{array}{r}0 \\
0 \\
-303\end{array}$ & $\begin{array}{r}642 \\
1151 \\
817\end{array}$ & $\begin{array}{l}-67 \\
211 \\
163\end{array}$ & $\begin{array}{l}A \\
c \\
A\end{array}$ \\
\hline
\end{tabular}




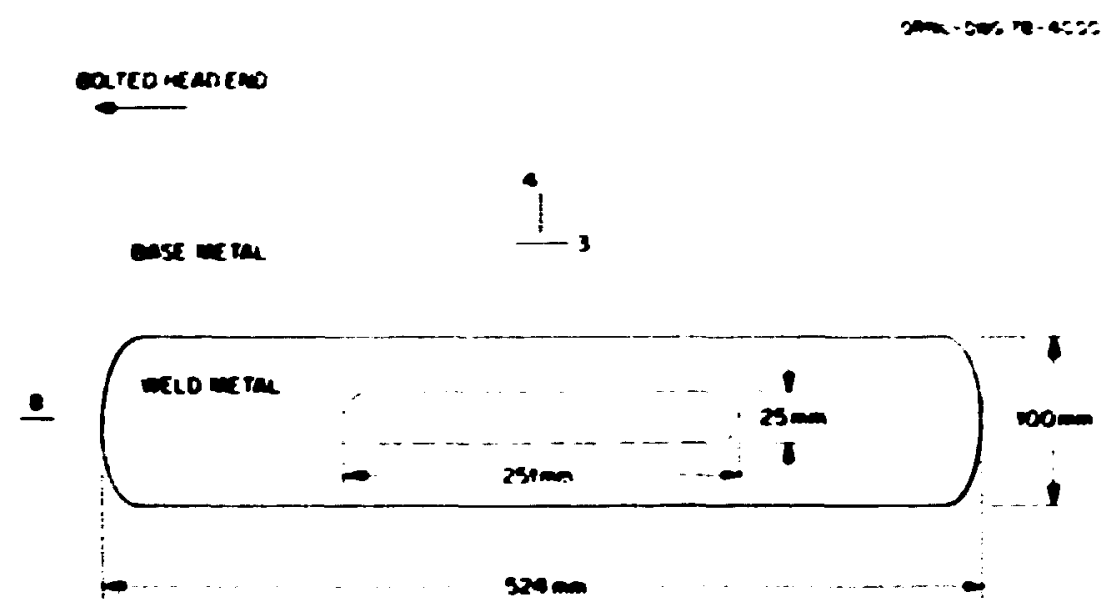

Fis. C.3. Weldable strain gage layout about the $v-7 A$ repair weld $(100 \mathrm{~m}=3.94 \mathrm{in}$.$) .$

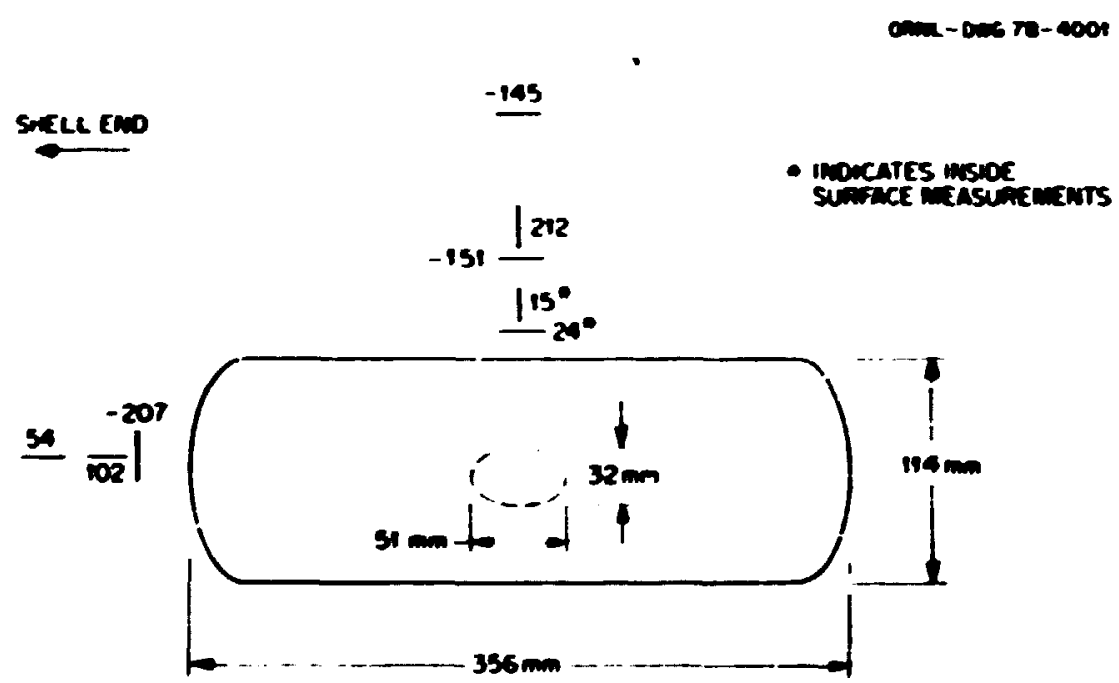

F18. C.4. V-7A simulacion repatr weld residual stresses (MPa) determined from weldable strain gage measurenente (1 Ma = 145 psi; 100 - 3.94 (n.).

Identified by a number and are show to scale relative to the weld cavity outline as seen from outside the prolongation and vessel in Figs. C. 7 and C.8. The residual stresses $(\sigma)$ listed in Tables C.3 and C.t were calculated from the cotal change in strain, $\Delta \mu \varepsilon$, by the wathod diecused in Chapter 4. These values are show relative to the wold covities in Fige. C.9 and C.10. 


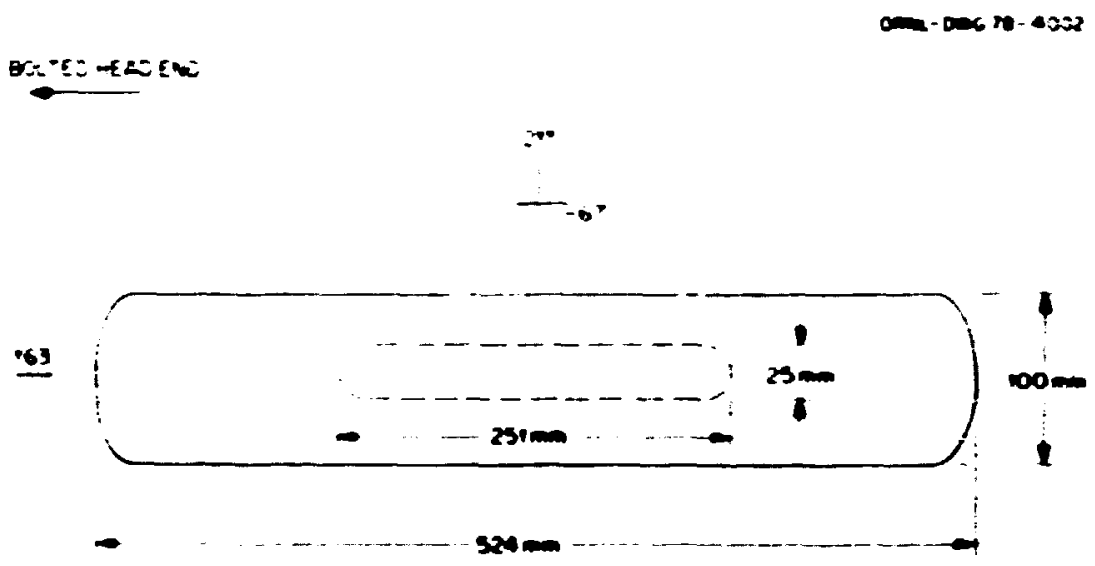

Fig. C.5. V-7A repait weld residual streases (EPa) decernined from veldable strain gage measurements (1 $\mathrm{RPa}=145 \mathrm{psi} ; 100=3.94 \mathrm{In}$.$) .$

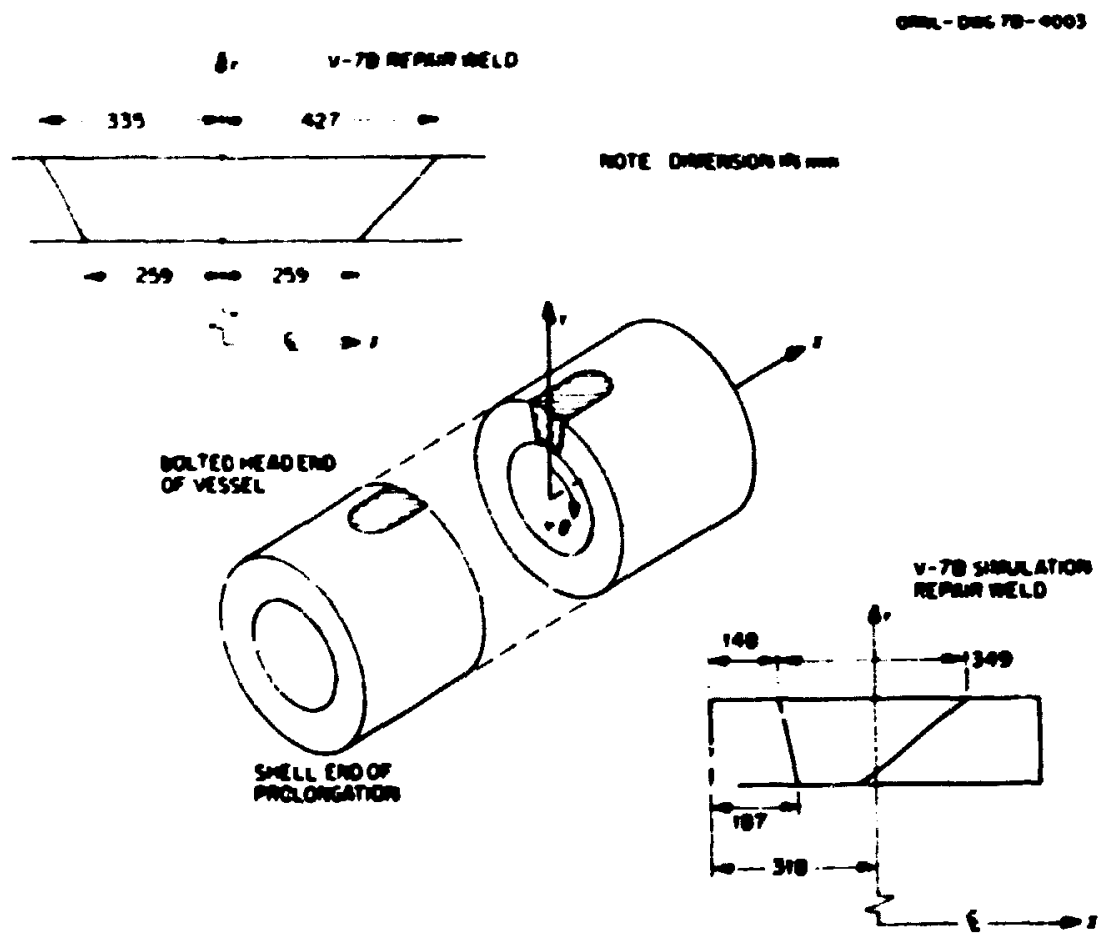

71B. C.6. Coordinate systen used to define the weidahle vtrain gage locatione Ileced in Tables C.3 and C.4. The rz plane is a plene of yyurtry for the V-7B simulation repalt weld and the V-7B repair weld. The it plane biects the V-8 prolongation and the interfor eurface outline of the vessel $V-7 B$ repale wald $(100 \mathrm{~m}=3.94 \mathrm{in.})$. 
Table C..3. Weldable strain gage results for the $t-7 B$ sieulat ion repair weld

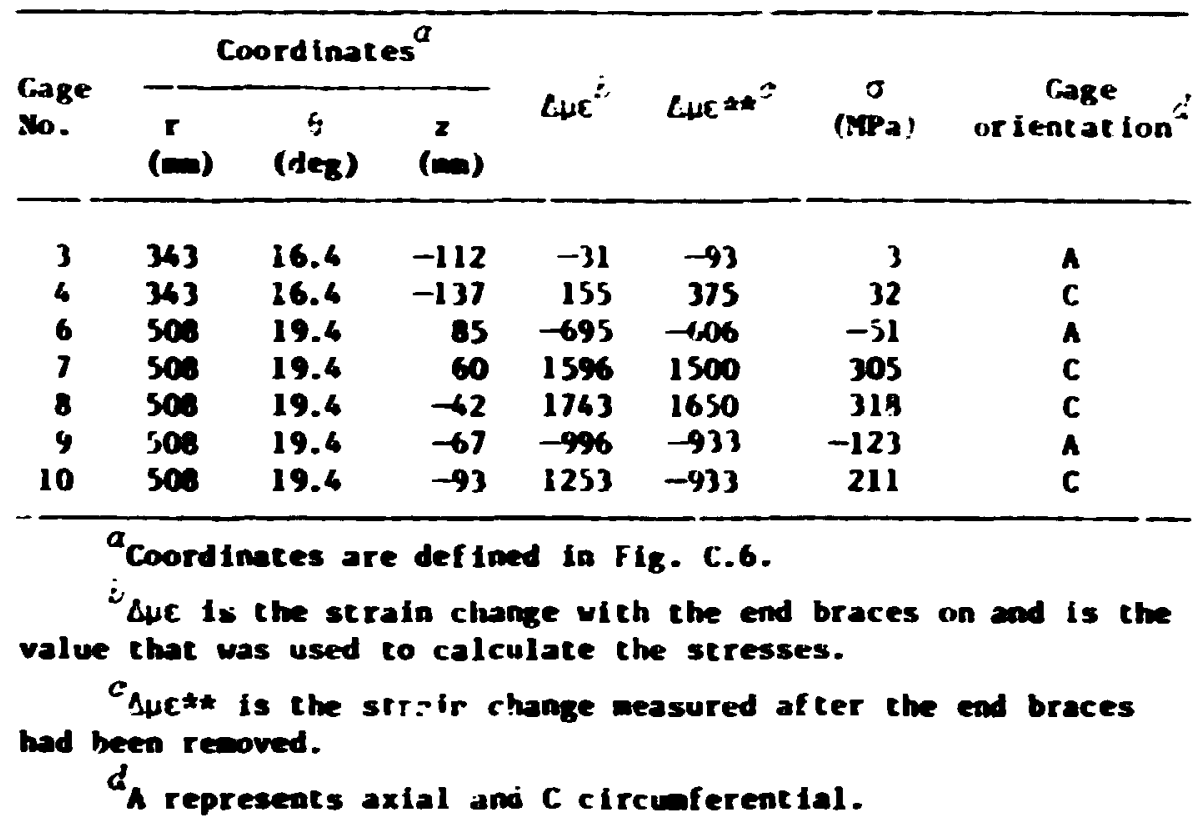

Table C.4. Weldable strain cage results for the V-7B repair weld

\begin{tabular}{|c|c|c|c|c|c|c|}
\hline \multirow{2}{*}{$\begin{array}{l}\text { Goge } \\
\text { lo. }\end{array}$} & \multicolumn{3}{|c|}{ Coordinates ${ }^{a}$} & \multirow[b]{2}{*}{$\Delta \mu \varepsilon$} & \multirow{2}{*}{$\frac{3}{(M a)}$} & \multirow{2}{*}{$\underset{\text { orientet }{ }^{2} b}{b}$} \\
\hline & $(m)$ & $\begin{array}{c}\theta \\
(d e)\end{array}$ & ${ }^{2}$ & & & \\
\hline $\begin{array}{l}31 \\
32 \\
33 \\
34 \\
35 \\
36 \\
37 \\
38 \\
39 \\
40 \\
41 \\
42 \\
43 \\
46 \\
45\end{array}$ & $\begin{array}{l}343 \\
343 \\
343 \\
343 \\
343 \\
343 \\
495 \\
495 \\
495 \\
495 \\
495 \\
495 \\
495 \\
495 \\
495\end{array}$ & $\begin{array}{l}15.9 \\
15.9 \\
15.9 \\
15.9 \\
15.9 \\
15.9 \\
13.2 \\
13.2 \\
13.2 \\
13.2 \\
13.2 \\
13.2 \\
13.2 \\
13.2 \\
13.2\end{array}$ & $\begin{array}{r}96 \\
68 \\
43 \\
-58 \\
-84 \\
-109 \\
226 \\
198 \\
173 \\
21 \\
-5 \\
-26 \\
-178 \\
-204 \\
-229\end{array}$ & $\begin{array}{r}-140 \\
577 \\
-191 \\
-64 \\
478 \\
-10 \\
1741 \\
-752 \\
1759 \\
1740 \\
-580 \\
1544 \\
1859 \\
-836 \\
1201\end{array}$ & $\begin{array}{r}6 \\
116 \\
-5 \\
16 \\
102 \\
28 \\
333 \\
-53 \\
336 \\
363 \\
-23 \\
300 \\
353 \\
-86 \\
209\end{array}$ & $\begin{array}{l}\text { C } \\
\text { A } \\
\text { C } \\
\text { C } \\
\text { A } \\
\text { C } \\
C \\
\text { A } \\
C \\
C \\
\text { A } \\
C \\
C \\
\text { A } \\
C\end{array}$ \\
\hline
\end{tabular}




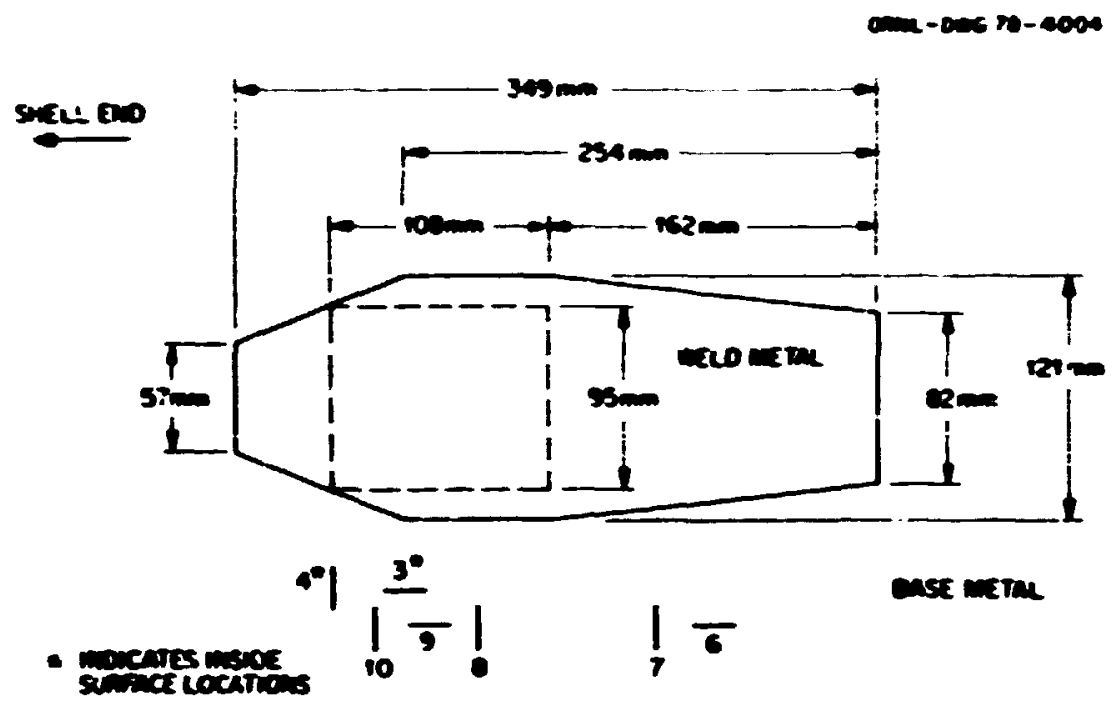

918. C.7. Weldable strain eage layout about the V-7b simlation repair weld (100 $=3.94 \mathrm{ln}$.).

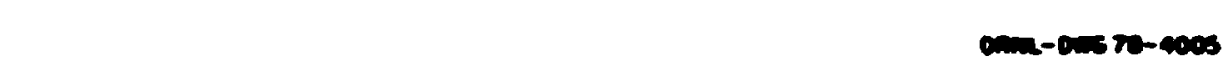

\section{COLTEO MEADENO}

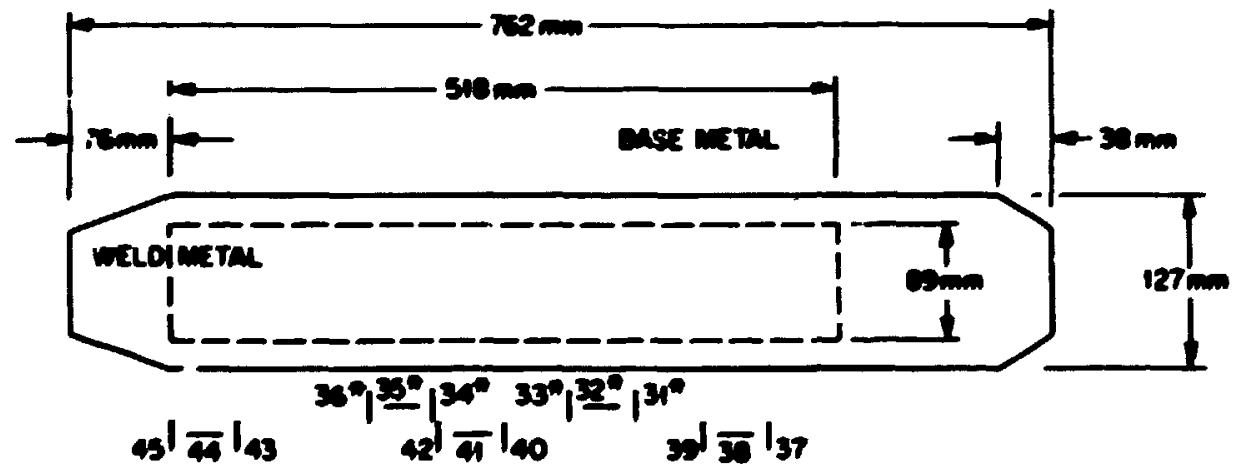

- Imacates lingos

sunice locentions

718. C.8. Weldable strata gage layout about the V-78 repalt weld $(100 \mathrm{~m}=3.84 \mathrm{in.})$. 


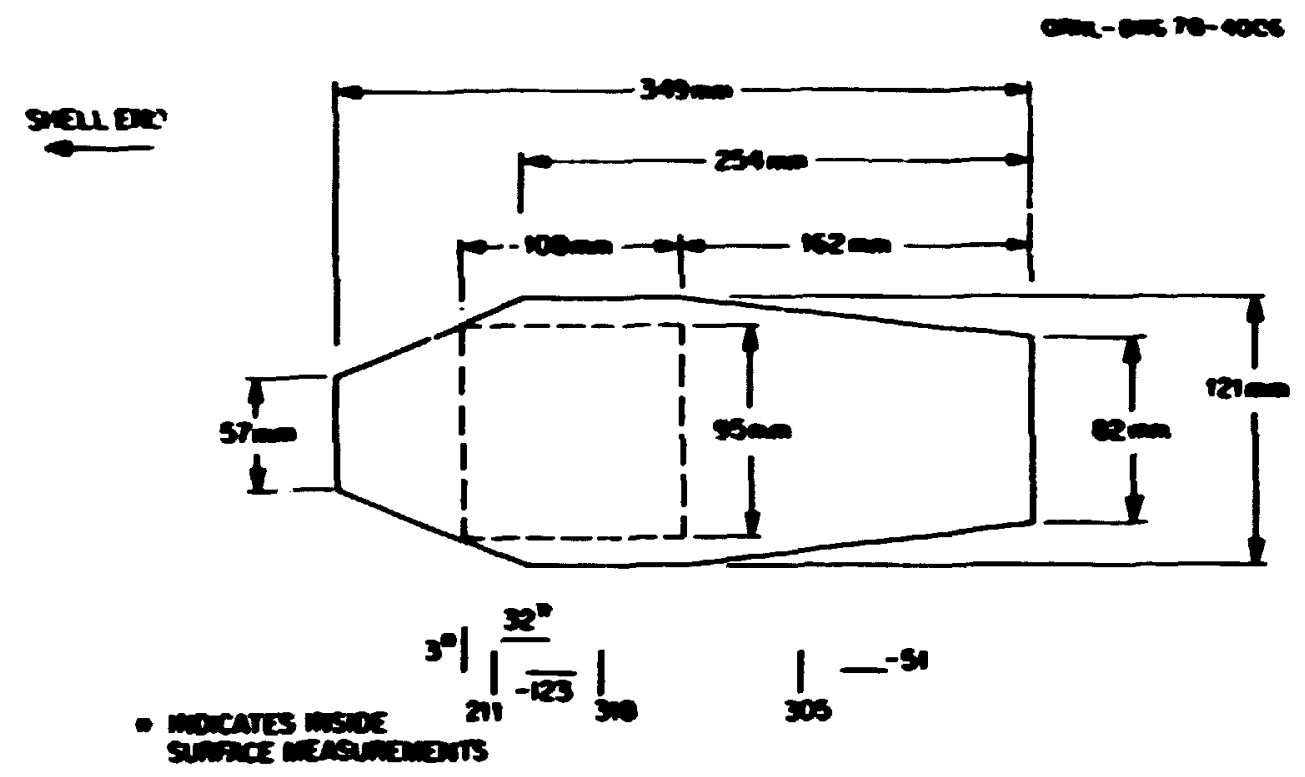

F18. C.9. V-7B siniation repatr weld residual stresees (Ma) deternined fro weldable strain page measurenents (1 Ma $=145$ pol; 100 $=3.94 \mathrm{in.})$. $-$

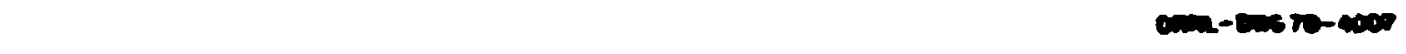

\section{Cared Geneso}

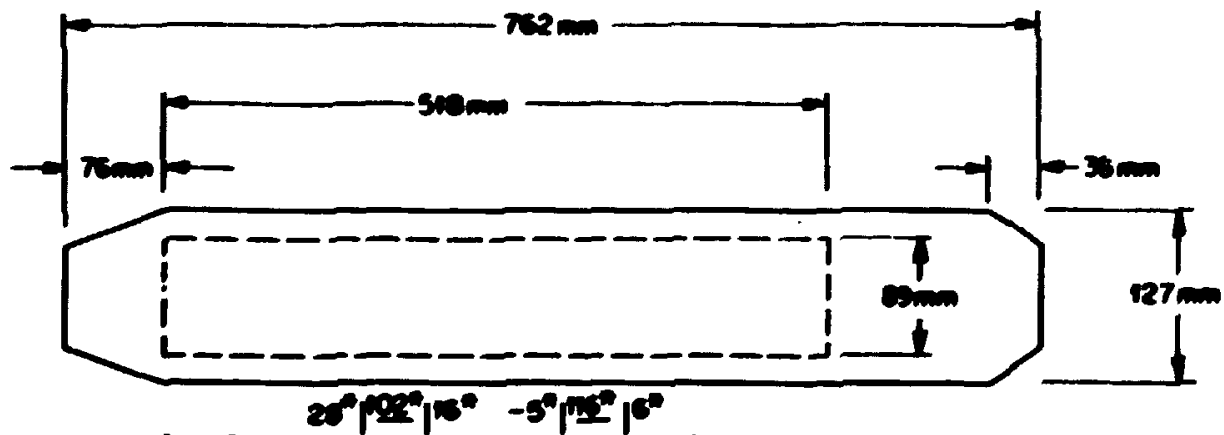

- Mancanse mines

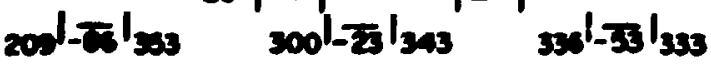

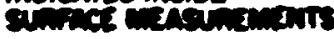

716. C.10. V-7B repeir weld restdual stresces (MPa) deternined from

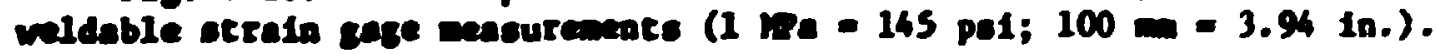


Appendix D

\section{V-8 SERIES REPAIR YELOS - MELDABLE}

STRAIN GaGe measUREdats

Appendix D contains the weldable strain gage data for the V-8 sinulation repair weld and the V-8 repair reld. A discussion relatiog to the weldable eage neasureneats is contained in Chapter $\therefore$.

Figure D.I shows the coordiante systen ued to reference centerpoincs of the weldable strain gages for the $v-8$ stalation repair weld (Table D.1) and the centerpolat: of che wldable strain gages for the $b-8$ repaix wid (Table D.2). The eages that are listed in each of chose cables are

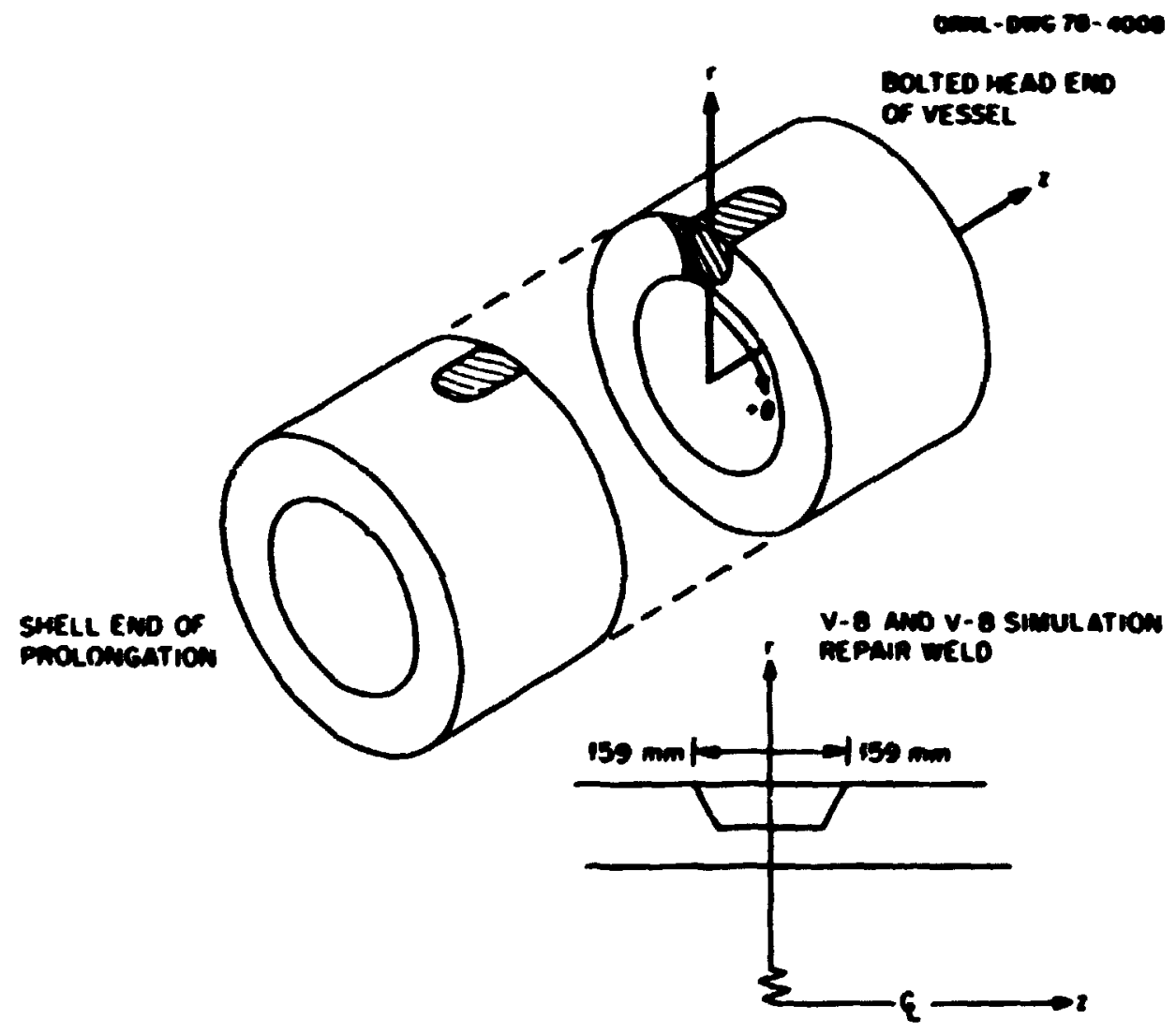

Fis. D.1. Coordinate syster used to define the midable strain gage locations listed in Tables $D .1$ and $D .2$. The $\mathrm{Tz}$ and $\mathrm{r} \theta$ planes are planes of symetry for both the V-8 simulation repolr weld and the $V-8$ repair veld $(100 \mathrm{~m}-3.94 \mathrm{in.})$. 
table 0.1. Welesble strata rane rebulte ti: ine i-t stwalation reatr uld

\begin{tabular}{|c|c|c|c|c|c|c|}
\hline \multirow{2}{*}{$\operatorname{cose}$} & \multicolumn{3}{|c|}{ coordientes } & \multirow[b]{2}{*}{ أمهـ } & \multirow{2}{*}{$\stackrel{n}{(5 x)}$} & \multirow{2}{*}{ Cone } \\
\hline & $\stackrel{r}{(m)}$ & $\left(\begin{array}{c}5 \\
(2)\end{array}\right.$ & $(\infty)$ & & & \\
\hline $\begin{array}{l}11 \\
12 \\
13 \\
14 \\
15 \\
16 \\
17 \\
11 \\
19 \\
20 \\
21 \\
22 \\
23 \\
24 \\
25 \\
26 \\
21 \\
20 \\
29 \\
30\end{array}$ & 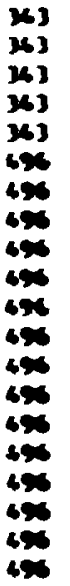 & $\begin{array}{r}0 \\
0 \\
0 \\
0 \\
0 \\
-10.7 \\
-10.7 \\
-10.7 \\
-10.7 \\
-10.7 \\
-10.7 \\
-10.7 \\
-10.7 \\
-10.7 \\
10.7 \\
10.7 \\
10.7 \\
10.7 \\
10.7 \\
10.7\end{array}$ & $\begin{array}{r}51 \\
25 \\
0 \\
-25 \\
-51 \\
121 \\
102 \\
76 \\
25 \\
0 \\
-25 \\
-25 \\
-102 \\
-122 \\
25 \\
51 \\
25 \\
-25 \\
-31 \\
-70\end{array}$ & $\begin{array}{r}222 \\
165 \\
222 \\
200 \\
231 \\
242 \\
-102 \\
1700 \\
1520 \\
-713 \\
1017 \\
1502 \\
-459 \\
691 \\
1502 \\
-754 \\
1540 \\
1616 \\
-711 \\
1570\end{array}$ & $\begin{array}{r}07 \\
105 \\
73 \\
97 \\
75 \\
145 \\
-45 \\
351 \\
320 \\
-50 \\
30 \\
100 \\
-35 \\
0\end{array}$ & $\begin{array}{l}t \\
A \\
c \\
A \\
c \\
c \\
a \\
c \\
c \\
A \\
c \\
c \\
A \\
c \\
c \\
A \\
c \\
c \\
A \\
c\end{array}$ \\
\hline
\end{tabular}

fcoordineces are defined in Fls. 0.1.

a represents anlol and circulerenclal.

Table 0.2. Lileble strais pop realts fer the ith repolr wid

\begin{tabular}{|c|c|c|c|c|c|c|}
\hline \multirow{2}{*}{$\cos$} & \multicolumn{3}{|c|}{ Cemertures" } & \multirow{2}{*}{$d x$} & \multirow{2}{*}{$\stackrel{0}{\left(\omega^{\prime}\right)}$} & \multirow{2}{*}{ or rencerse } \\
\hline & $\underset{(\infty)}{t}$ & $(4)$ & $(0)$ & & & \\
\hline $\begin{array}{l}11 \\
12 \\
13 \\
16 \\
15 \\
16 \\
17 \\
10 \\
19 \\
20 \\
21 \\
22 \\
23 \\
26 \\
25 \\
26 \\
27 \\
25 \\
29 \\
30 \\
31 \\
32 \\
33 \\
36 \\
35\end{array}$ & 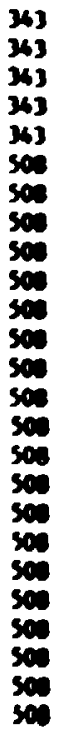 & $\begin{array}{c}0 \\
0 \\
0 \\
0 \\
0 \\
10.6 \\
10.6 \\
10.6 \\
10.6 \\
10.6 \\
10.6 \\
10.6 \\
10.6 \\
10.6 \\
-10.6 \\
-10.6 \\
-10.6 \\
-10.6 \\
-10.6 \\
-10.6 \\
0 \\
0 \\
0 \\
0 \\
0\end{array}$ & $\begin{array}{r}-51 \\
-25 \\
0 \\
25 \\
51 \\
-121 \\
-102 \\
-76 \\
-25 \\
0 \\
25 \\
70 \\
102 \\
121 \\
-76 \\
-51 \\
-25 \\
25 \\
51 \\
76 \\
-205 \\
-235 \\
-201 \\
-216 \\
-311\end{array}$ & 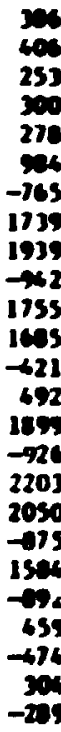 & $\begin{array}{r}110 \\
101 \\
11 \\
02 \\
16 \\
161 \\
131 \\
346 \\
-63 \\
326 \\
341 \\
-21 \\
81 \\
354 \\
-72 \\
422 \\
342 \\
-76 \\
240 \\
-165 \\
51 \\
-79 \\
62 \\
-46\end{array}$ & 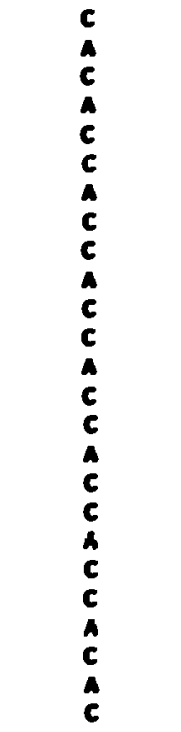 \\
\hline
\end{tabular}

coordinates ore definat is Mig. D.2.

ba foe esclal and $C$ for ciremiermetel. 
identified by nubers and are shom to scale relative to the weid cavity outlines as seea from outside the $5-8$ prolongation and che $v-8$ vessel in Figs. D. 2 and D.3. The cotal change in strains, ia: $E$ in the tables, were deternined by zeroing the gages at room temperature just prior to heatup for the weld repair and then recording the strain upon complection of the weld repair and after the prolongation and vessel had been brought back to the nominal roon cemperature. The total strain measurement for the V-8 simlation repair weld was with the end braces in place; however, for reasens stated in Appendix $C$, this is not considered significant. The

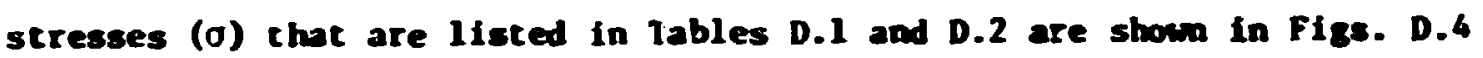
and D.S relative to the weld cavicy outline where the weld cavity and the solid I ines indicating gages are dram to scale. The stresses were calculated by the methods described in Chapter 4.

cone-0us re-400s

SHELL ENO

2 positive

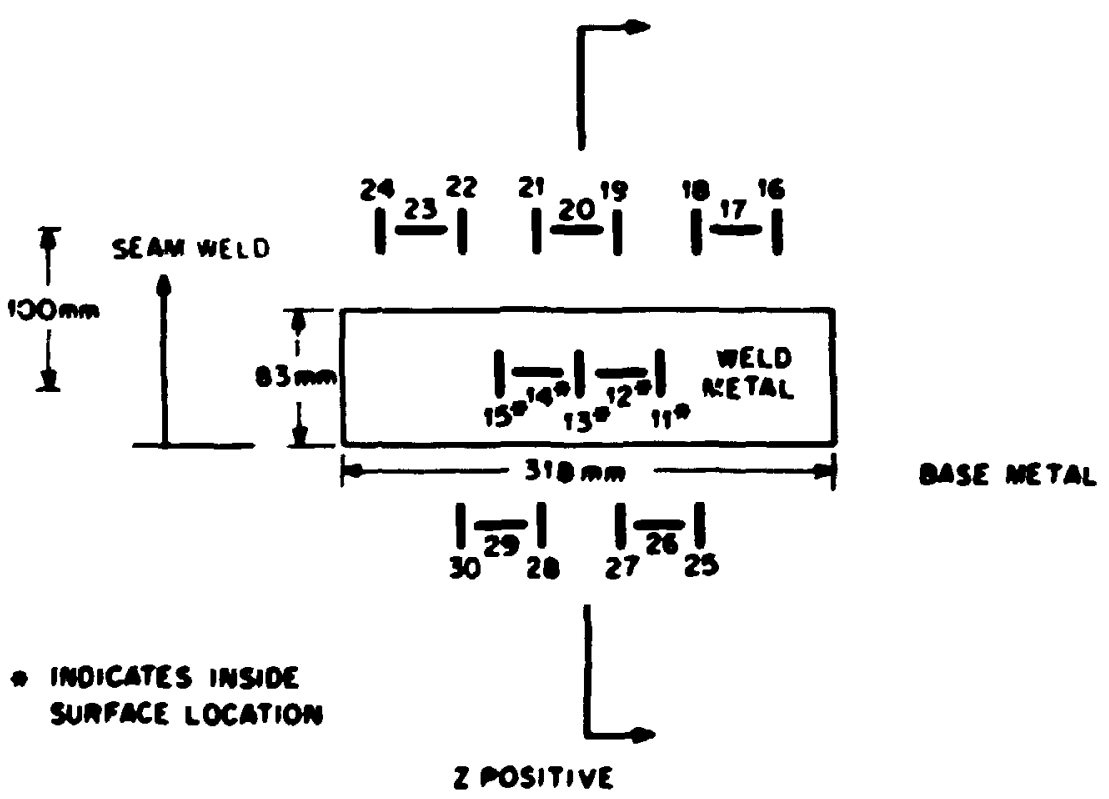

F18. D.2. Weldable strain gage layout about the V-8 sinulation repalr weld. See Table D.1 (100 $=3.94 \mathrm{in.})$. 


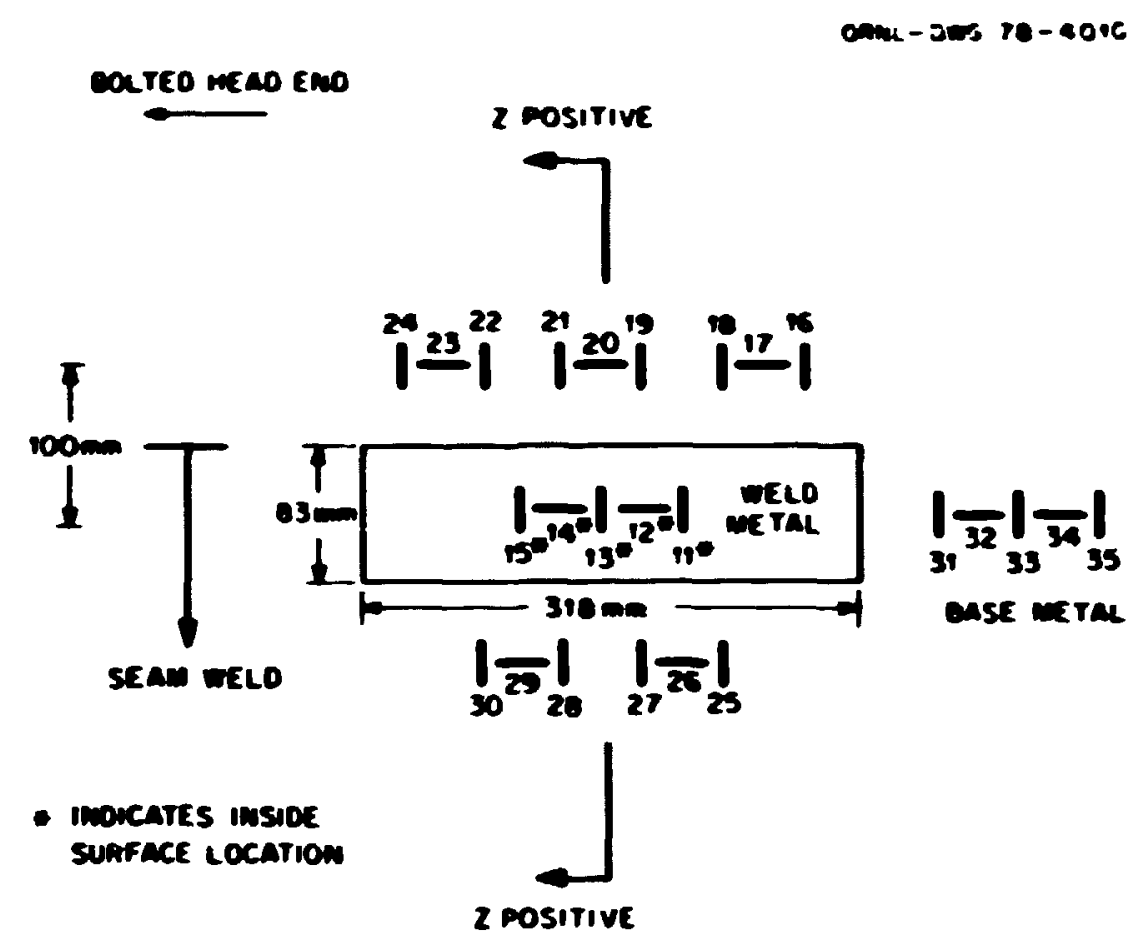

Fig. D.3. Weldable strain gage layout about the $V-8$ repair weld. See Table $D .2(100 \mathrm{~mm}=3.94 \mathrm{in}$.$) .$

Shele Eno

$\operatorname{com}-\cos \pi-400$

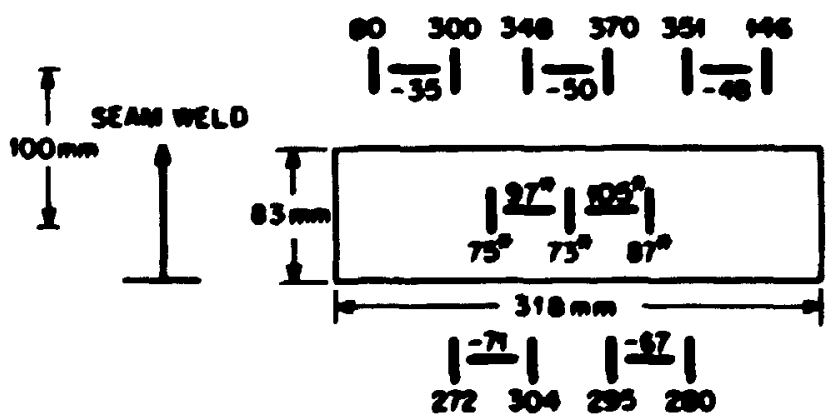

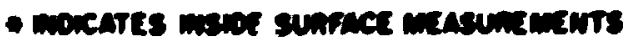

F16. D.4. V-8 simulation repair wid residuel etresses (MPa) decermined from weldable strain gage measurements (1 ipa = 145 psi; 100 $=3.94 \mathrm{in.}$ ). 


\section{DOLTEO HEAO ENO}

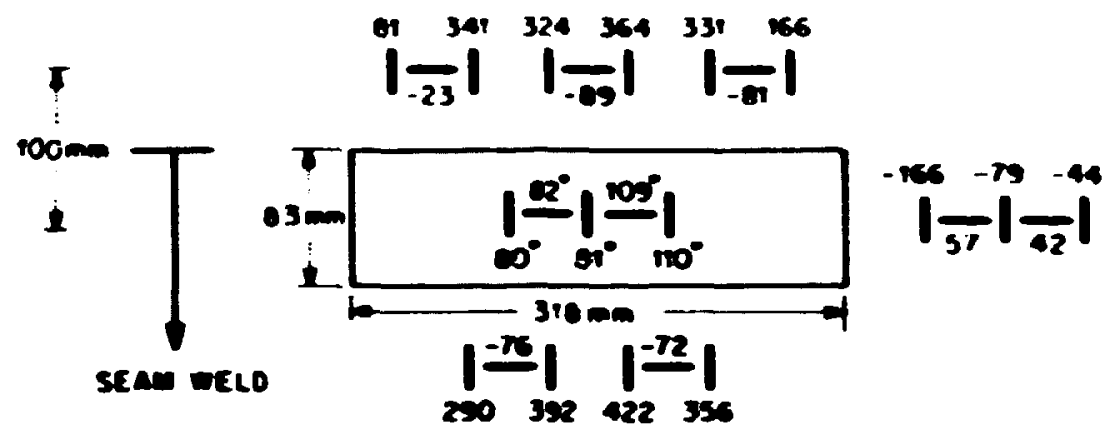

-inocates inside sunface measunements

Fig- D.5. V-8 repair weld residual stresses (HPa) decernined from weldable strain gage measureante ( $\mathrm{PPa}=145 \mathrm{psi} ; 100 \mathrm{ma}=3.94 \mathrm{in}$.). 
Appendix $\bar{E}$

U-7 SERIES REPAIR WELDS - HOLE-DR L. I.:ST MEASLREYENTS

Appendix E contains the hole-drilling data for the $\mathrm{l}$-7A simulation repair weld and the $V-7 i$ simulation repair weld. A discussion relating tc the hole-drilling measurement technique is contalned in Chapter 4. Table E.I is a sumary of the figures and data contalned in this appendix. Figures E.I and E.16 define cylindrical coordinate systems that are used in locating points where hole-drilling type measurewents were made. Figures E.2, E. 3, E.6, E.9, E.12, E.13 and E.17 are scale draulngs which indicate the location of numbered measurement sites relative to the appropriace weld casity outline. The remalinder of rhe figures show stresses that were calculated from the strain recorded during the drilling operation. Thic coordinates of each measurement point and the measured strain as a result of drilling are listed in Tables E.2 through E.7. The orientations of the strain rosetces relative to the angle $P$ or $B$ and the principal axes are defined in the figures showing the relative locations of the numbered seasurement sites. The principal stresses were resolved into two of the following categorles which are listed ta the tables: circumferential stress, $\sigma_{c}$, axial stress, $\sigma_{a}$, and/or the radial stress, $\sigma_{r}$. The measured hole dianeter is identified as $d$.

The data presented in this appendix were measured either at MRNL or at WRDC. The original source of the HRDC data is contained in Ref. 1 . The ORNL data were obtained by using a mechanfcal drill and thus the correction of 78 uE discussed in Appendix $B$ was added to each of the recorded strain values. The WRDC data were obtained using an abrasive drilling technique which did not require a correction.

A. J. Bush, Reoldual Streeses in Repair Weld of Thiok-Walled Presoure Vesoel, Westinghoure Research Report 78-1P6-APILC-R1 (1968). 


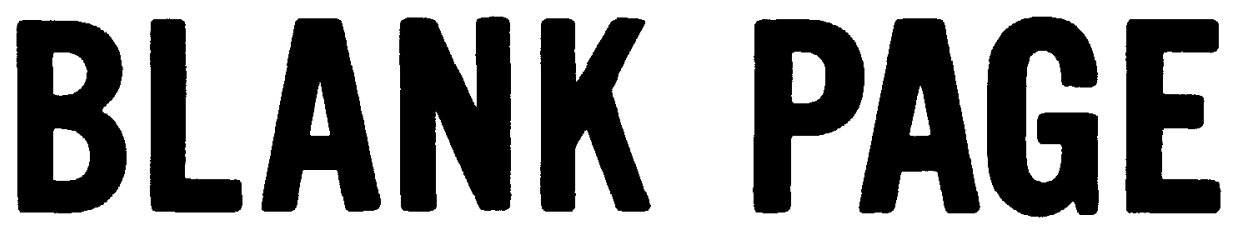


Table E.1. Swanty of date presented in Appendix $z$

\begin{tabular}{|c|c|c|c|c|c|c|c|c|c|c|c|}
\hline Ple. & $\begin{array}{l}\text { Coondinate } \\
\text { oyetem } \\
\text { inf ined }\end{array}$ & $\begin{array}{c}\text { Wold } \\
\text { esmentarion }\end{array}$ & $\sec \tan ^{a}$ & $\begin{array}{l}\text { Imenurcineme } \\
\text { Jocet lons } \\
\text { dof Ined }\end{array}$ & $\begin{array}{c}\text { Circuaforential } \\
\text { atroas }\end{array}$ & $\begin{array}{l}\text { Axtal } \\
\text { ofrenes }\end{array}$ & $\begin{array}{l}\text { Radial } \\
\text { atrease }\end{array}$ & $\begin{array}{l}\text { Surface } \\
\text { mosaureann: a }\end{array}$ & $\begin{array}{l}\text { Through- } \\
\text { inticunece } \\
\text { mosourceonts }\end{array}$ & $\begin{array}{l}\text { Souper } \\
\text { of data }\end{array}$ & $\begin{array}{c}\text { Takle } \\
\text { so. }\end{array}$ \\
\hline 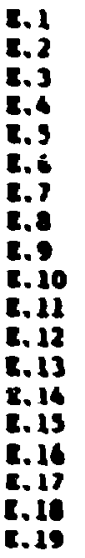 & $x$ & $\begin{array}{l}v-7 A \\
v-7 A \\
v-7 A \\
v-7 A \\
v-7 A \\
v-7 A \\
v-7 A \\
v-7 A \\
v-7 A \\
v-7 A \\
v-7 A \\
v-7 A \\
v-7 A \\
v-7 A \\
v-7 A \\
v-7 B \\
v-7 B \\
v-7 B \\
v-7 B\end{array}$ & $\begin{array}{l}\text { Uncue } \\
\text { Uncut } \\
\text { Uncut } \\
\text { Uncut } \\
\text { Uncut } \\
\text { A } \\
\text { A } \\
\text { A } \\
\text { A } \\
\mathbf{A} \\
\mathbf{C} \\
\mathbf{C} \\
\mathbf{C} \\
\mathbf{C} \\
\mathbf{B} \\
\mathbf{B}\end{array}$ & $\begin{array}{l}\begin{array}{l}x \\
x\end{array} \\
x \\
x \\
x \\
x\end{array}$ & $\begin{array}{l}x \\
x\end{array}$ & $\begin{array}{l}x \\
x \\
x\end{array}$ & $\begin{array}{l}x \\
x \\
x \\
x\end{array}$ & $\begin{array}{l}\text { intelde } \\
\text { instde } \\
\text { outeide } \\
\text { ineide }\end{array}$ & $\begin{array}{l}x \\
x \\
x \\
x \\
x \\
x \\
x \\
x \\
x \\
x \\
x \\
x \\
x \\
x\end{array}$ & 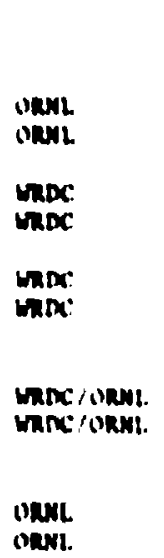 & 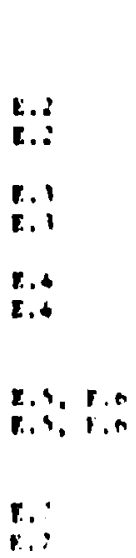 \\
\hline
\end{tabular}




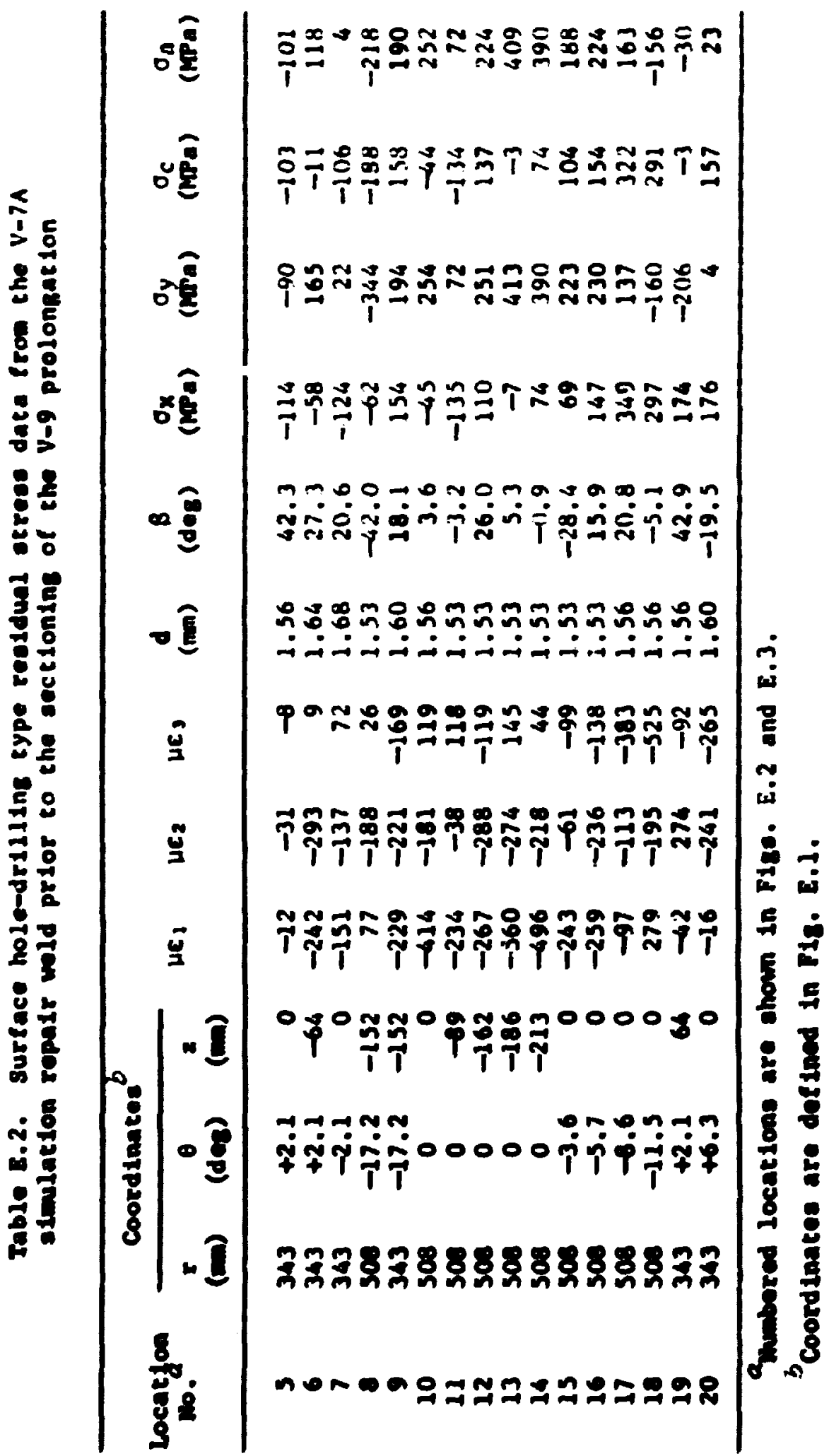




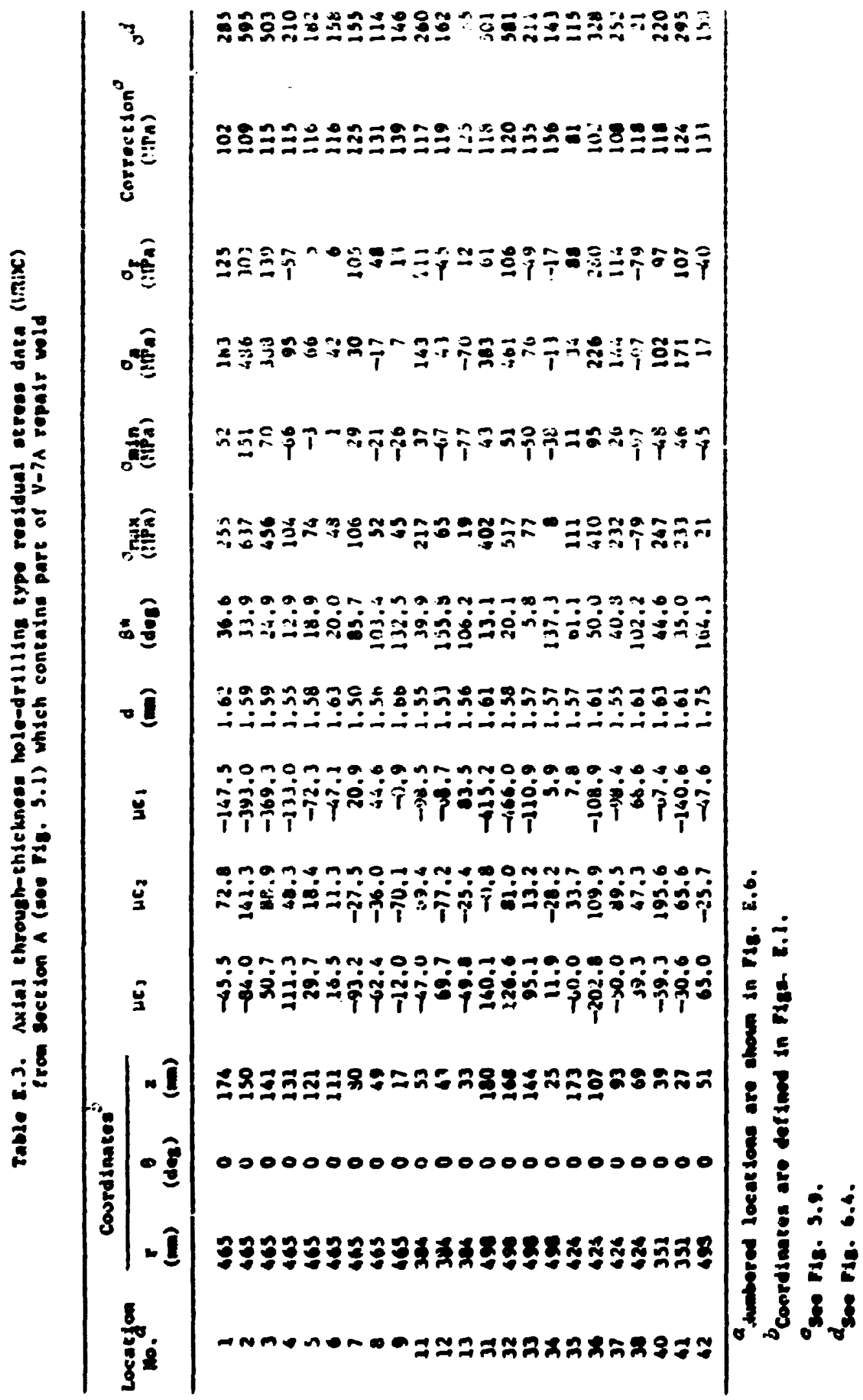




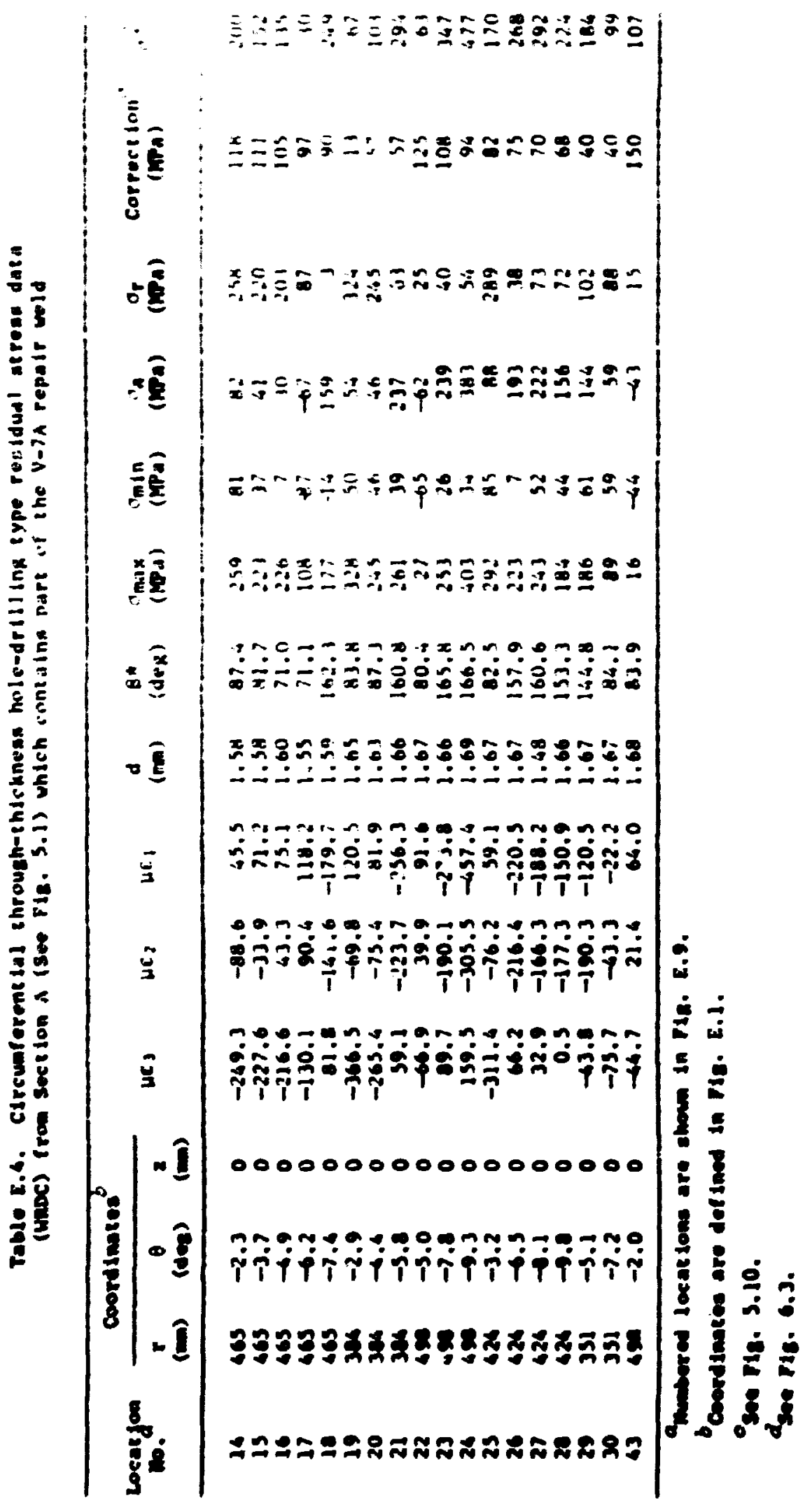




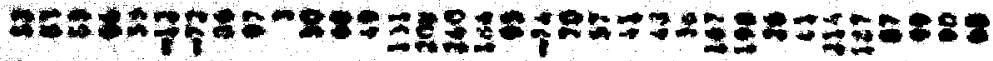

12

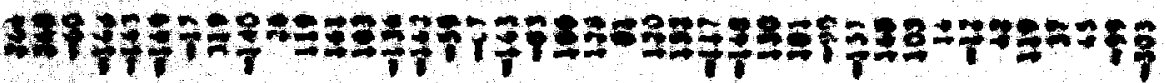

$+2$

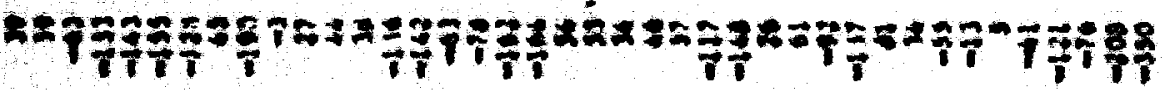

$+2$

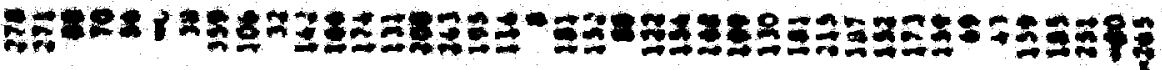

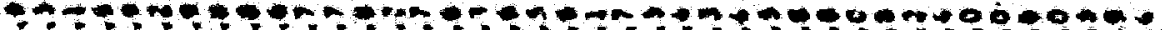

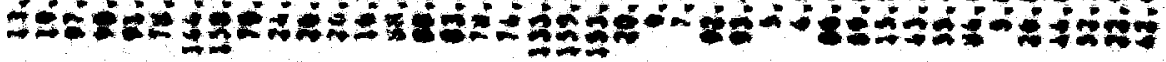

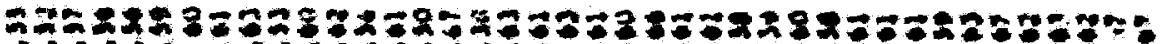

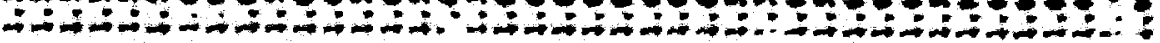

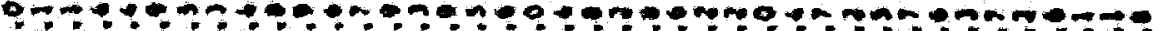

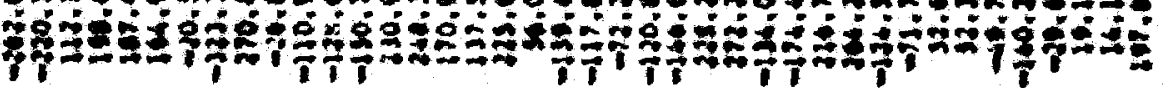

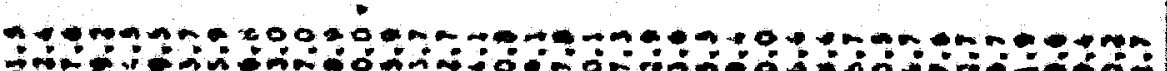

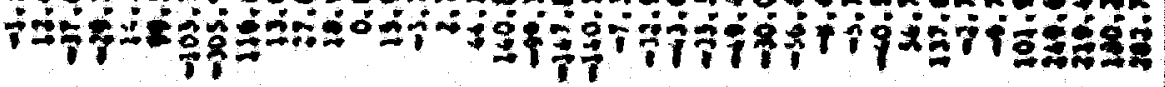

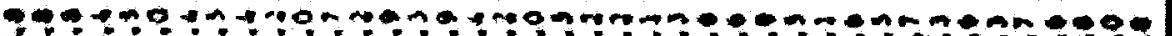

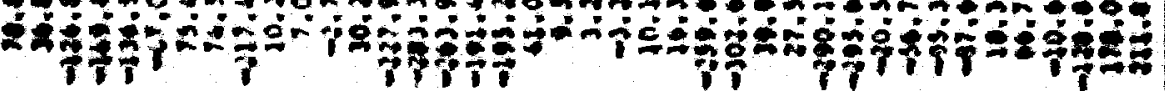

0000000000000000000000000000000000922227

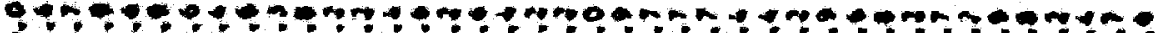

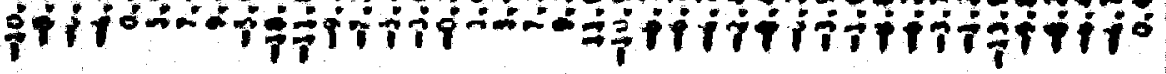

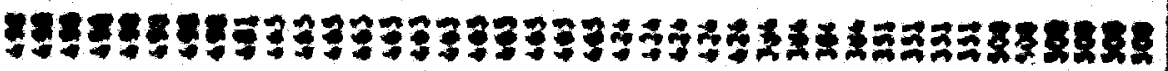




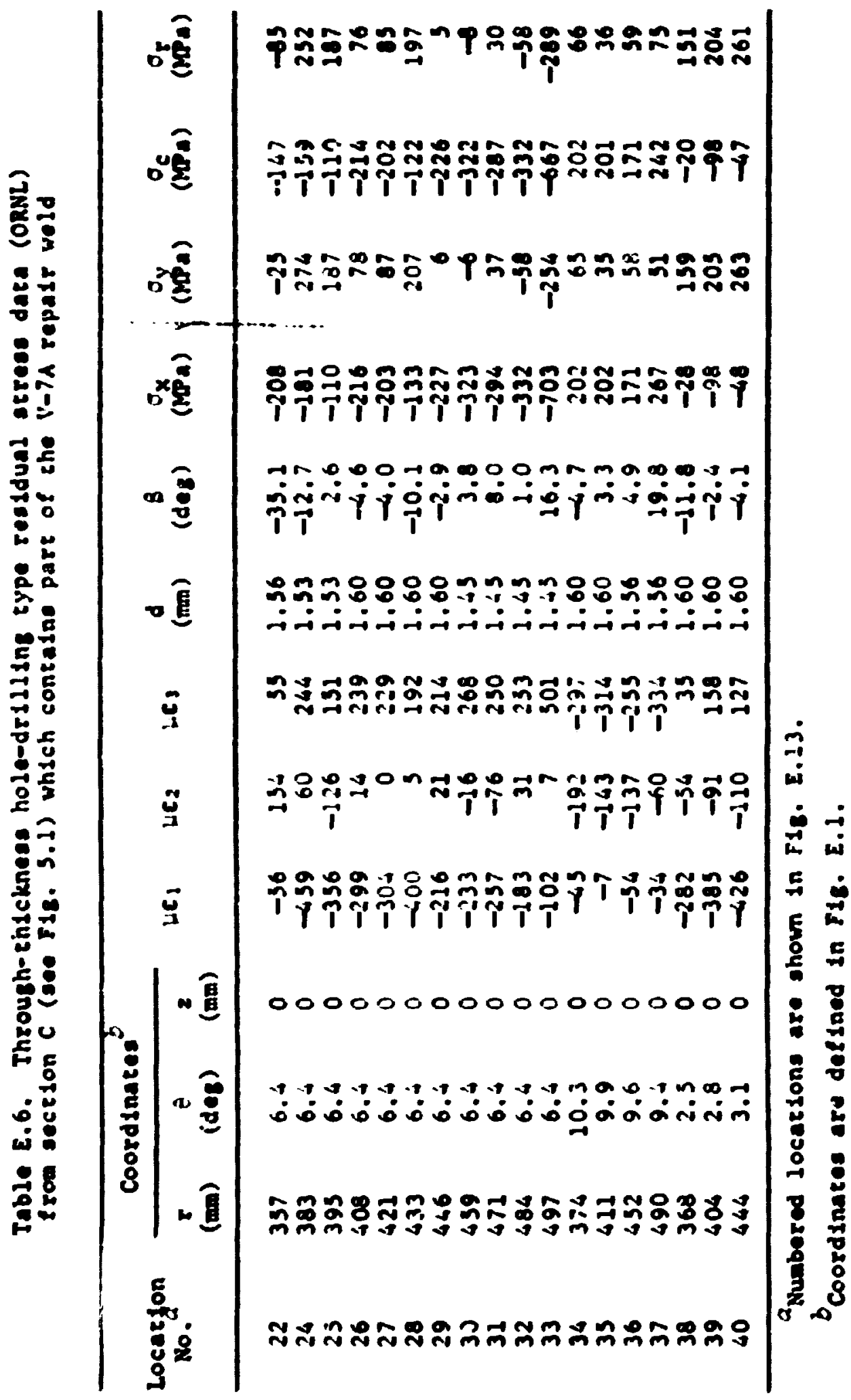


Table 5.7. Through-ehicknese hole-drsliling type reoldual otrece data from section D (see F1s. 3.1) whlch contelas part of the V-7s ropalt weld

\begin{tabular}{|c|c|c|c|c|c|c|c|c|c|c|c|c|}
\hline \multirow{2}{*}{$\begin{array}{l}\text { Location } \\
\text { 10. }\end{array}$} & \multicolumn{3}{|c|}{ Coordsanees ${ }^{b}$} & \multirow[b]{2}{*}{ WE 1} & \multirow[b]{2}{*}{ uEz } & \multirow[b]{2}{*}{ LEs } & \multirow{2}{*}{$\stackrel{d}{(n)}$} & \multirow{2}{*}{$\stackrel{8}{(\operatorname{deg})}$} & \multirow{2}{*}{$\stackrel{\sigma_{x}}{\left(\omega_{a}\right)}$} & \multirow{2}{*}{$\sigma_{y}(x)$} & \multirow{2}{*}{$\stackrel{\theta_{c}}{(r+s)}$} & \multirow{2}{*}{$\mathscr{0}_{\mathbf{r}}$} \\
\hline & $(5)$ & $\stackrel{\theta}{(d e s)}$ & $(5)$ & & & & & & & & & \\
\hline $\begin{array}{l}1 \\
2 \\
3 \\
4 \\
5\end{array}$ & $\begin{array}{r}470 \\
470 \\
470 \\
470 \\
470\end{array}$ & $\begin{array}{c}-7.4 \\
4.3 \\
0 \\
4.3 \\
7.4\end{array}$ & $\begin{array}{l}0 \\
0 \\
0 \\
0 \\
0\end{array}$ & $\begin{array}{r}58 \\
-90 \\
-291 \\
-102 \\
131\end{array}$ & $\begin{array}{r}-494 \\
-73 \\
-79 \\
-24 \\
-197\end{array}$ & $\begin{array}{r}-565 \\
-72 \\
40 \\
-52 \\
-914\end{array}$ & $\begin{array}{l}1.36 \\
1.33 \\
1.64 \\
1.33 \\
1.33\end{array}$ & $\begin{array}{r}-18.8 \\
-20.8 \\
-7.8 \\
7.8 \\
0.4\end{array}$ & $\begin{array}{r}482 \\
-2 \\
-23 \\
-17 \\
366\end{array}$ & $\begin{array}{r}44 \\
12 \\
154 \\
14 \\
-11\end{array}$ & $\begin{array}{r}436 \\
-1 \\
-20 \\
-16 \\
366\end{array}$ & $\begin{array}{r}90 \\
10 \\
131 \\
13 \\
-11\end{array}$ \\
\hline
\end{tabular}

a sumbered locations are shown in Fis. E.17.

bcoordinatee are shom in Fis. E.16. 


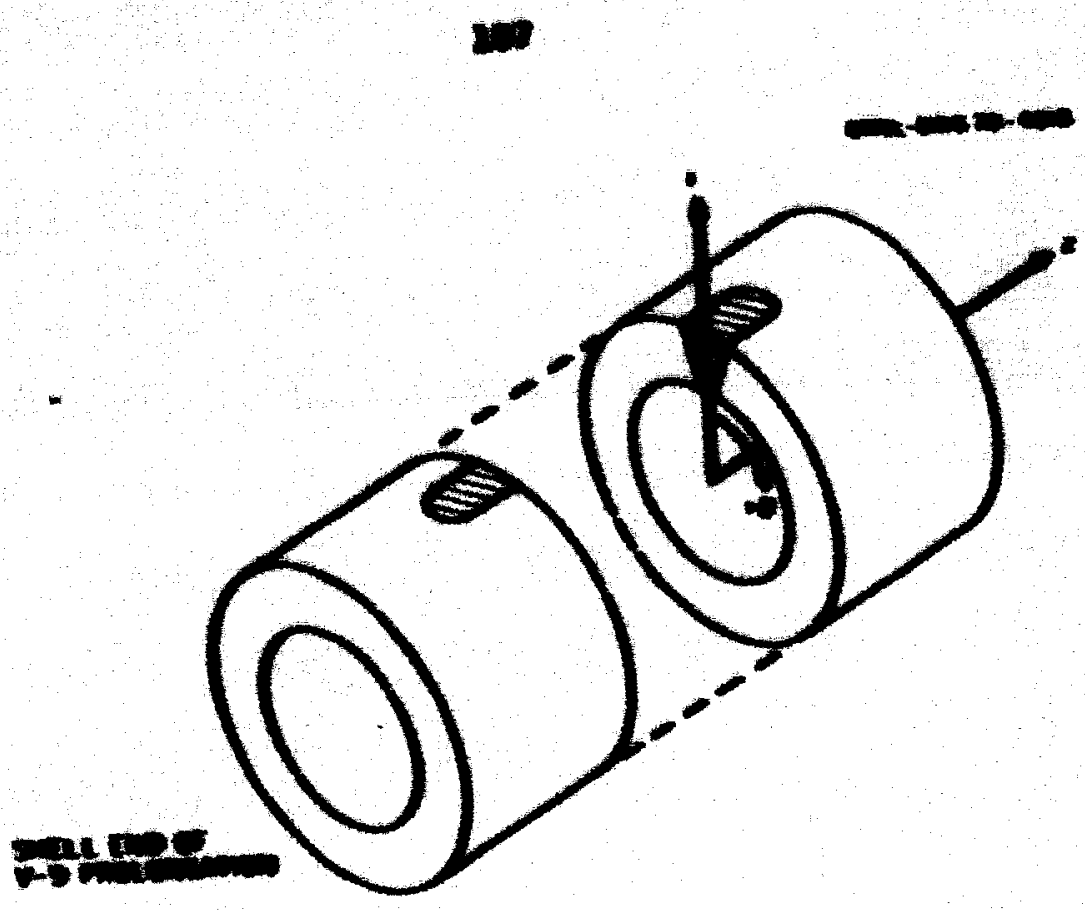

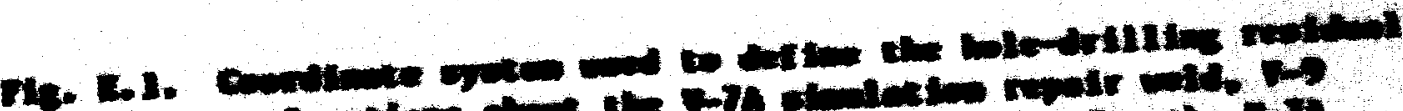

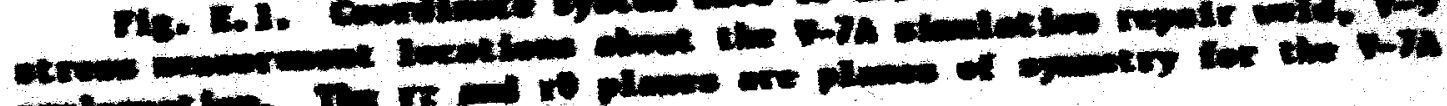

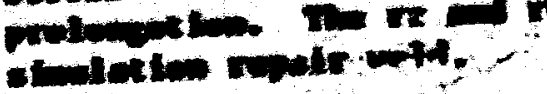
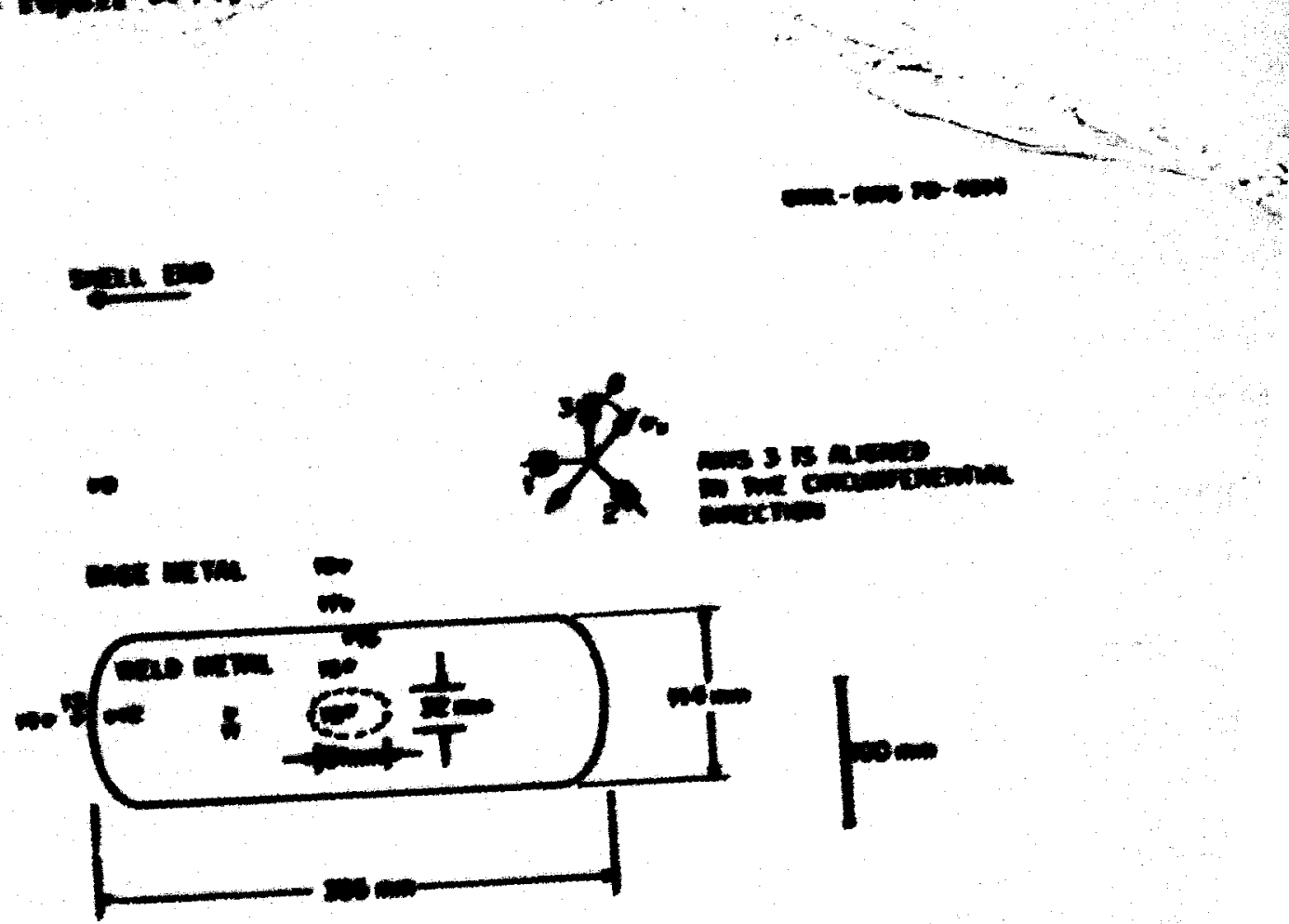

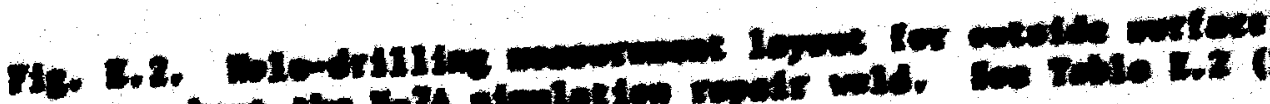

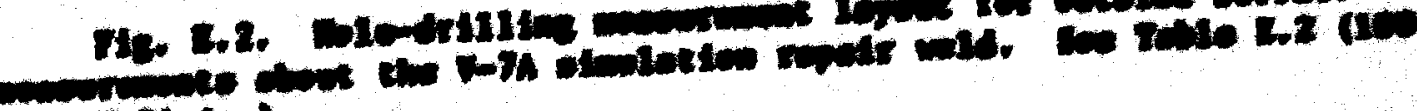
$\sin$ thot. 
$\sin 2$

are sta

-8)

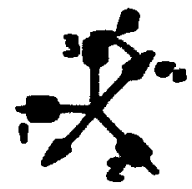

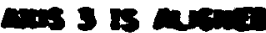

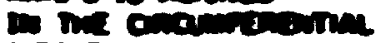
encitio
-

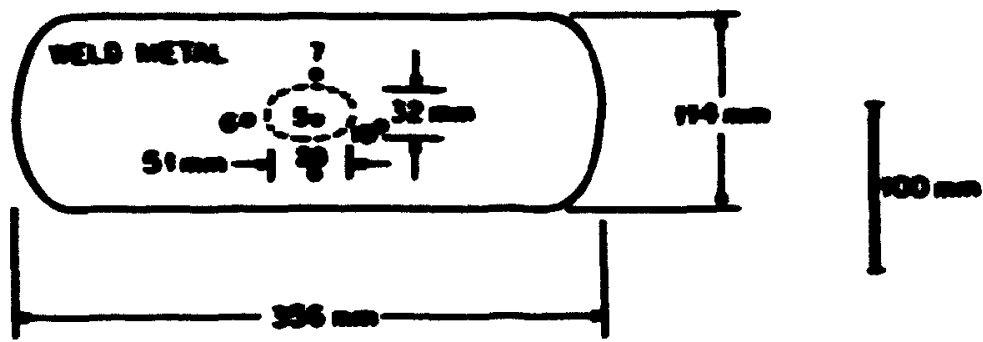

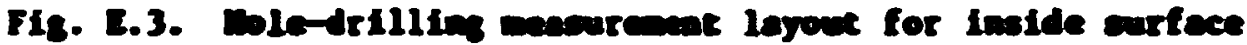

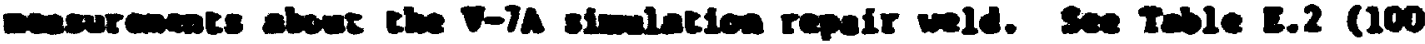
- 3.84 in.).

$\cos -\cos 20-\cos$

Enderters

$-20$

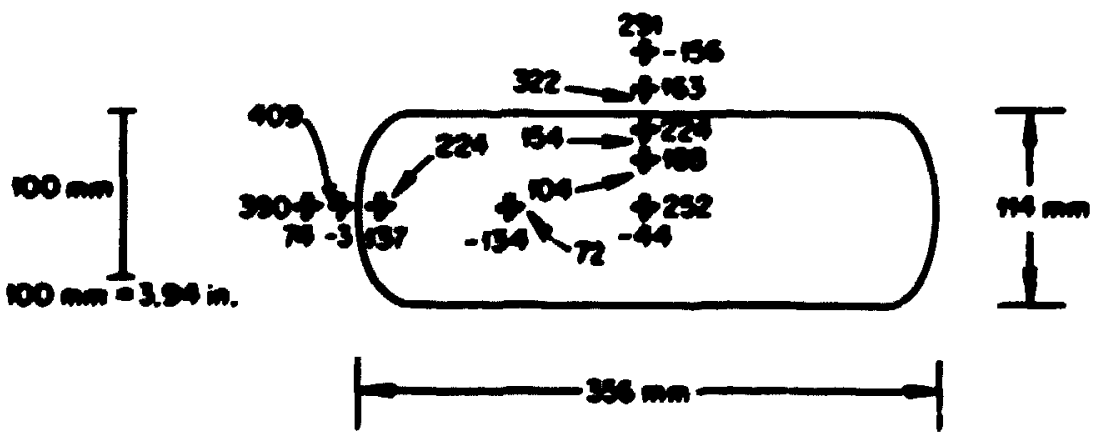

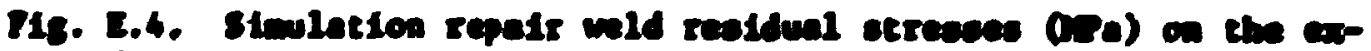

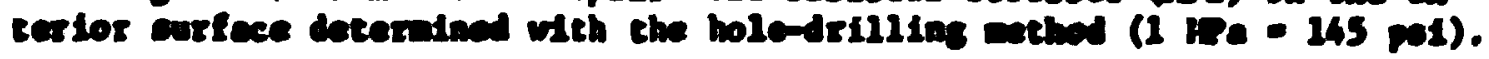




\section{sucen}

$\cos -\cos n-\cos$

-

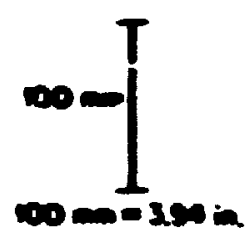

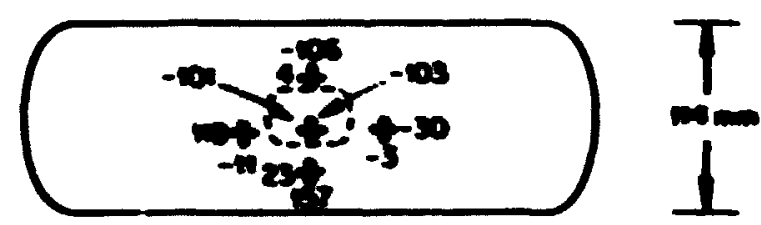

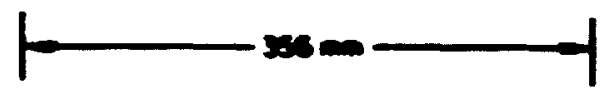

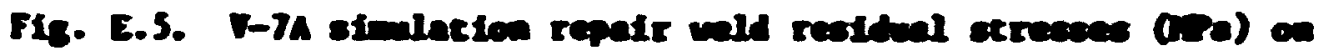

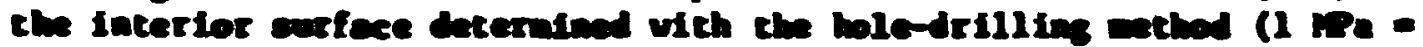
145 pet.).

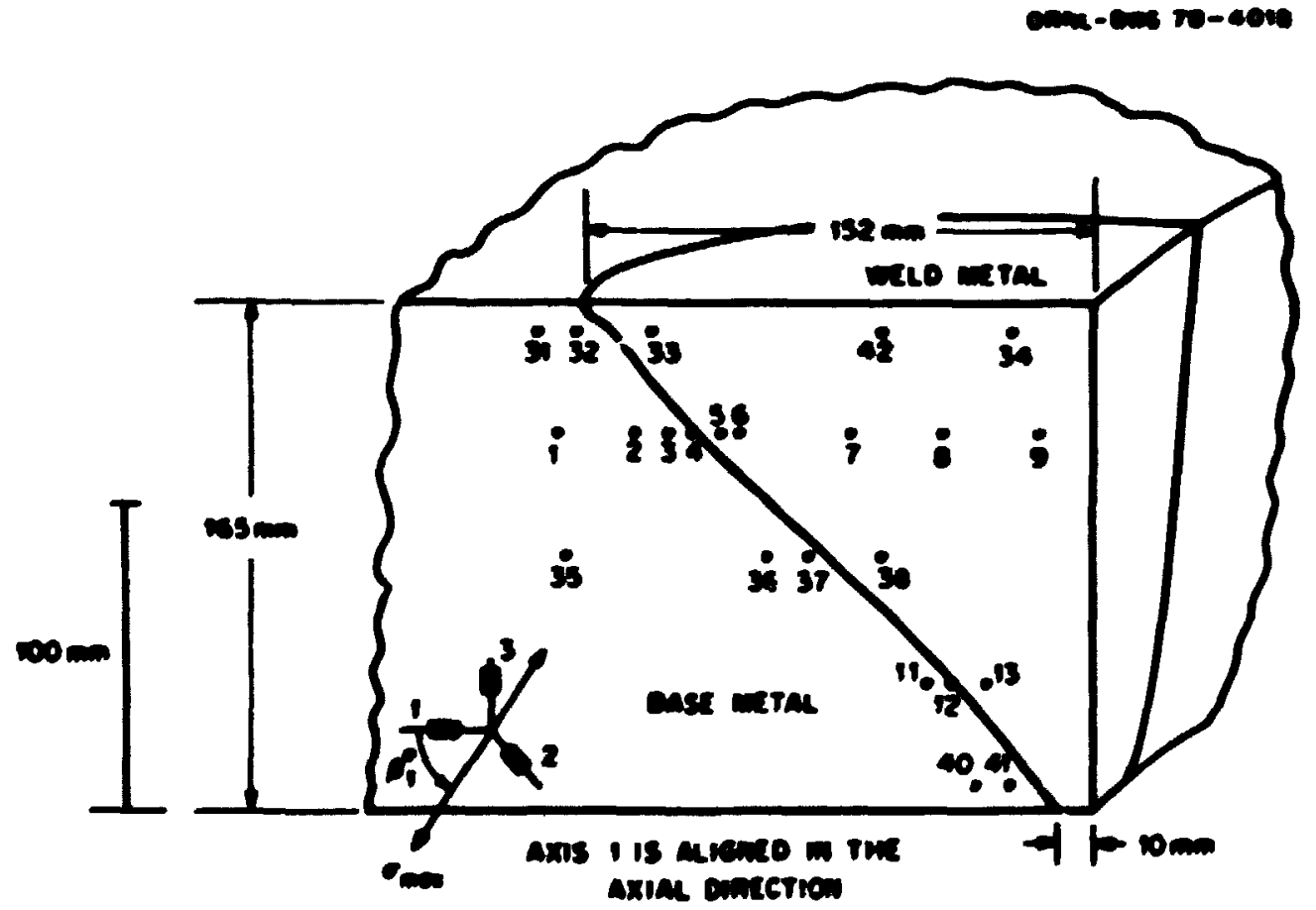

118. 2.6. Molo-dri11103 mencureme lajout for meanurenente on a

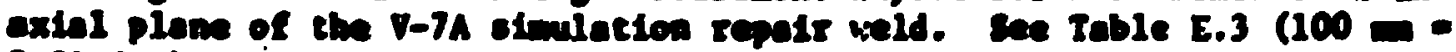
3.84 (a.). 


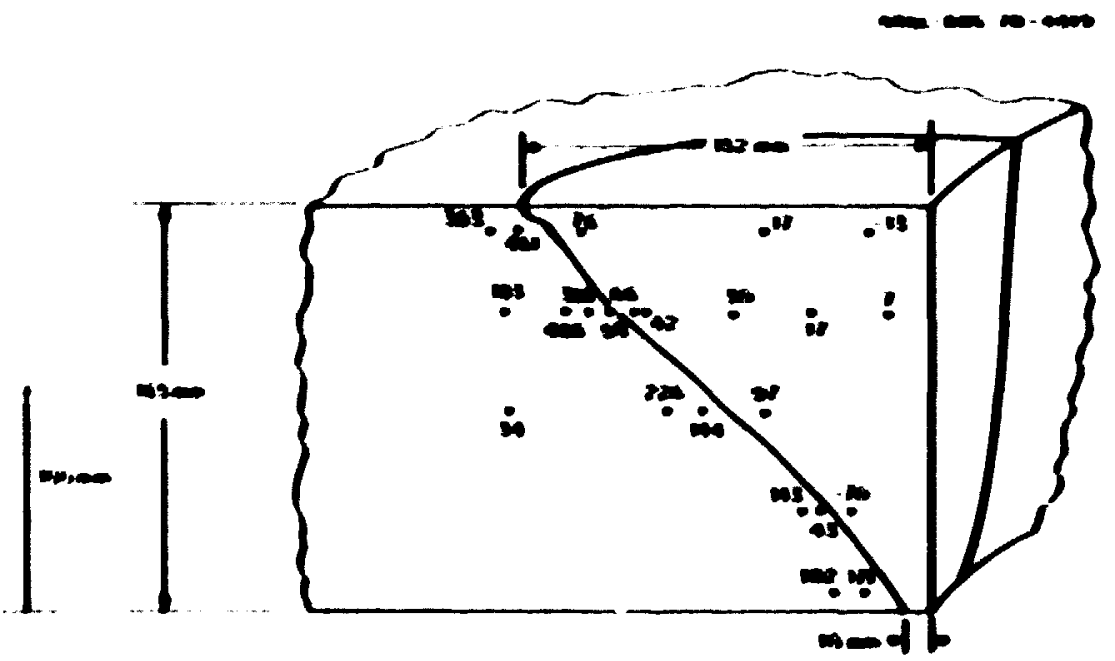

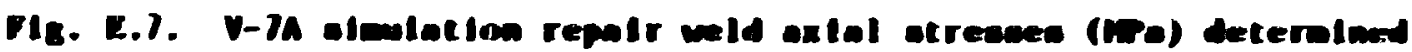

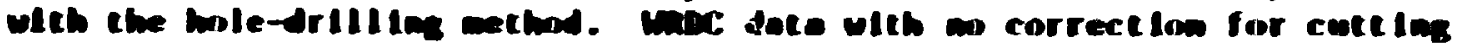

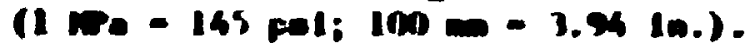

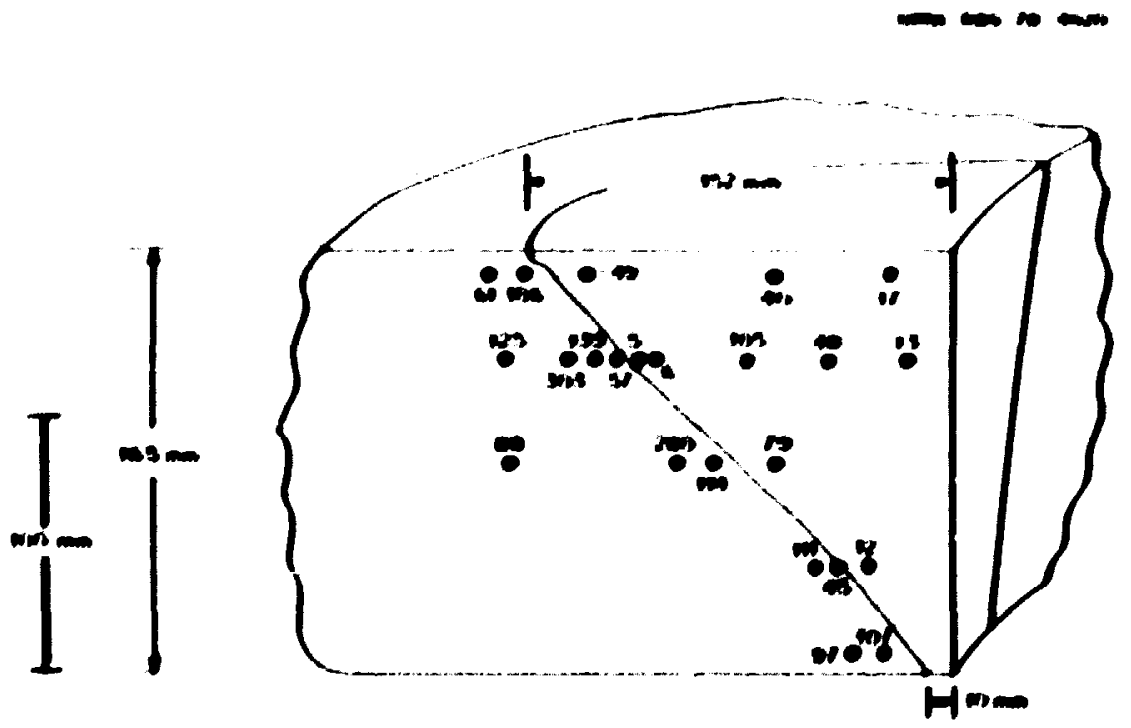

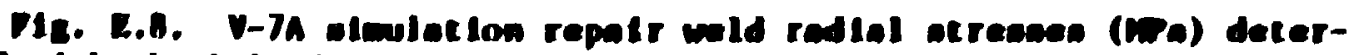

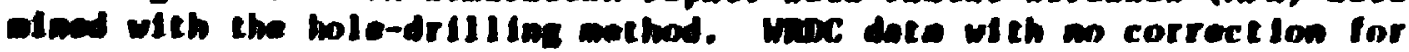

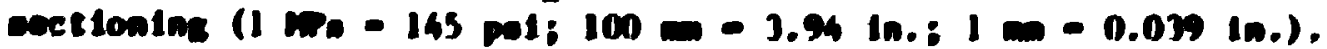




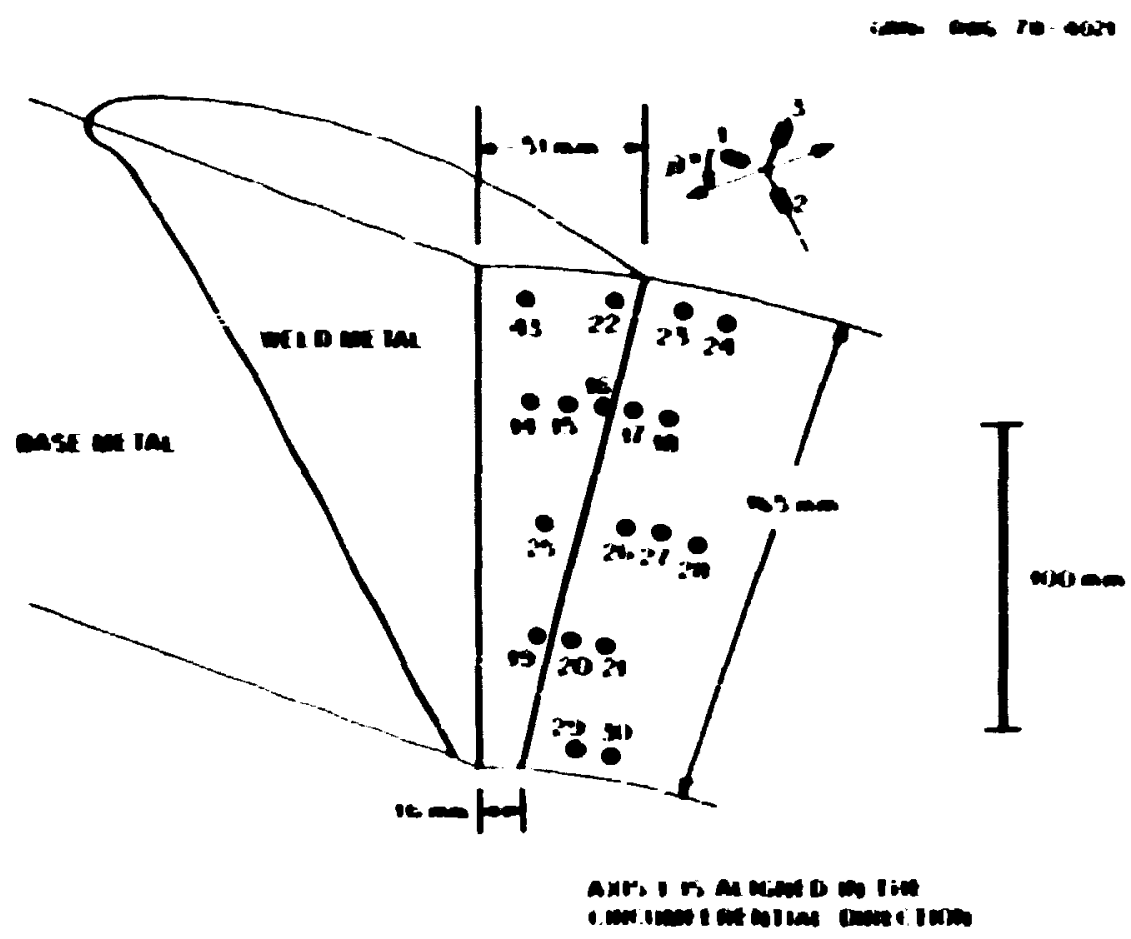

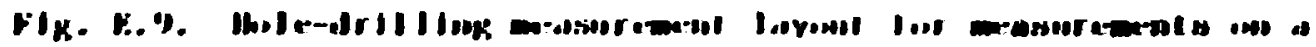

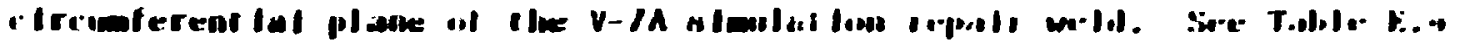
$(I(X)=-1.0 \%$ In. $)$.

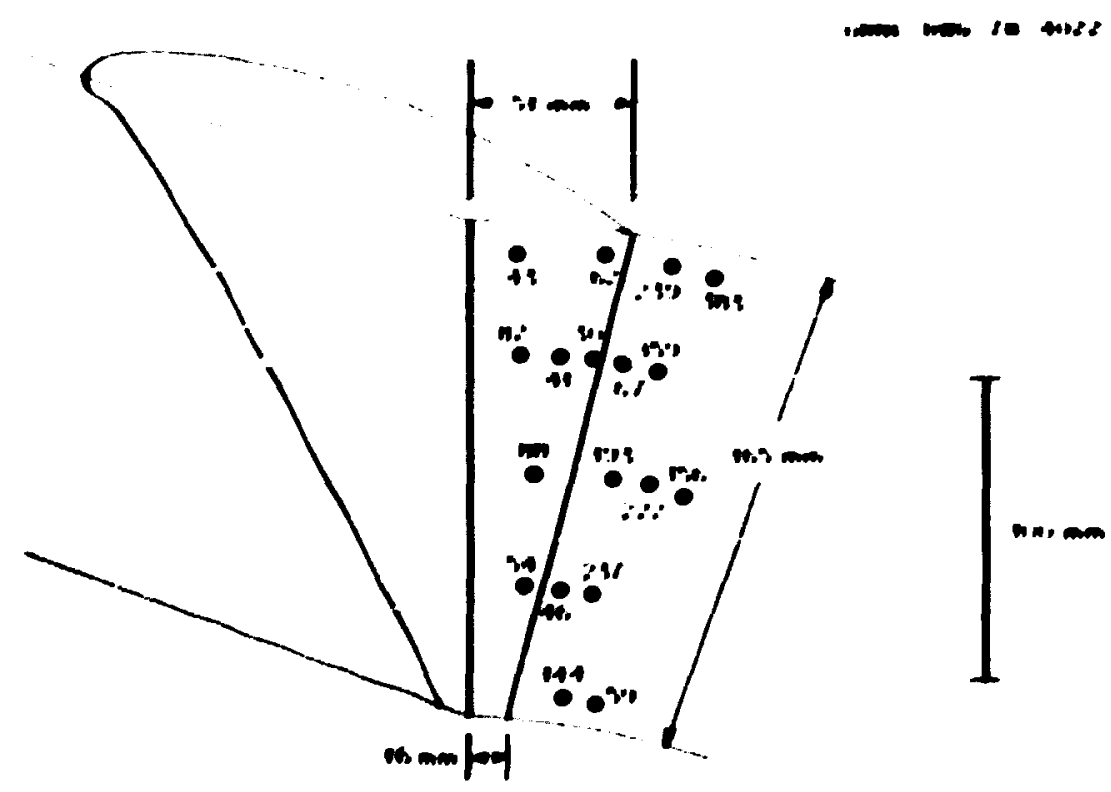

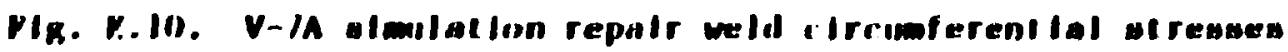

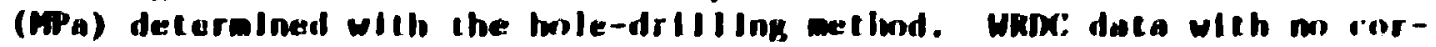

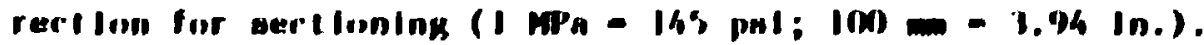


$0.0014-0.6023$

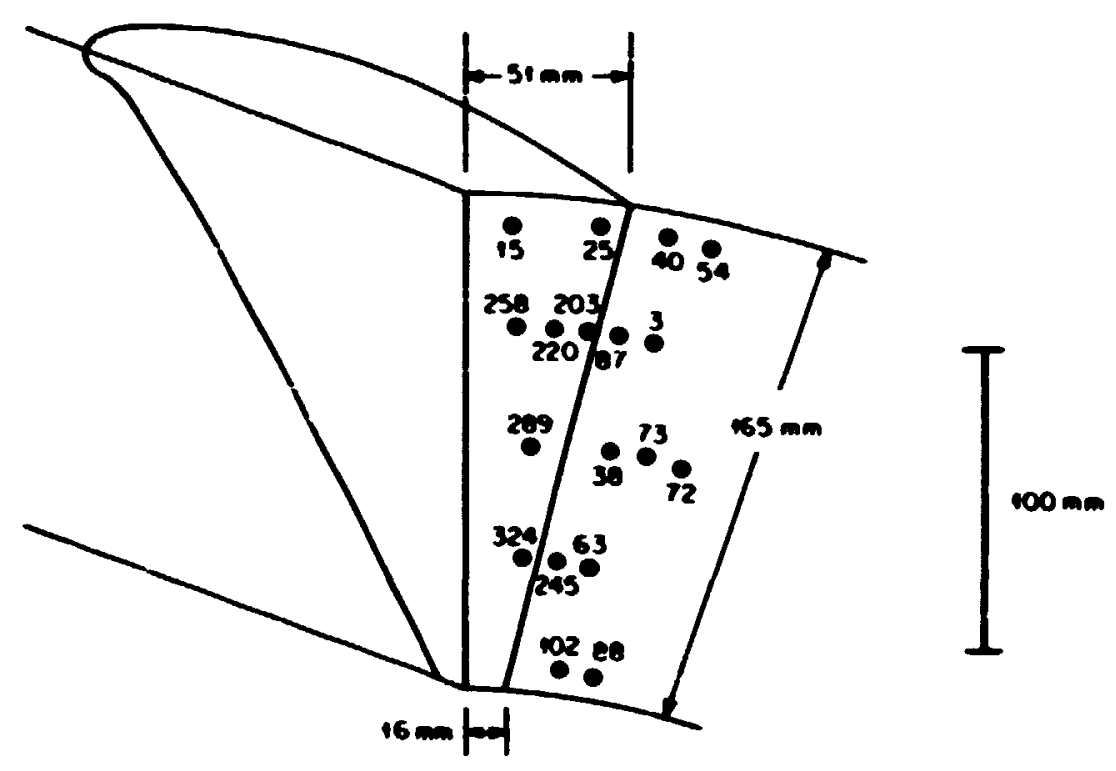

Fig. E.11. V-7A simulation repair weld radial stresses (HPa) deternined with the hole-drilling wethod. WRDC data with no correction for sectioning it MPa $=145 \mathrm{psi} ; 100=3.94 \mathrm{in.}$.).

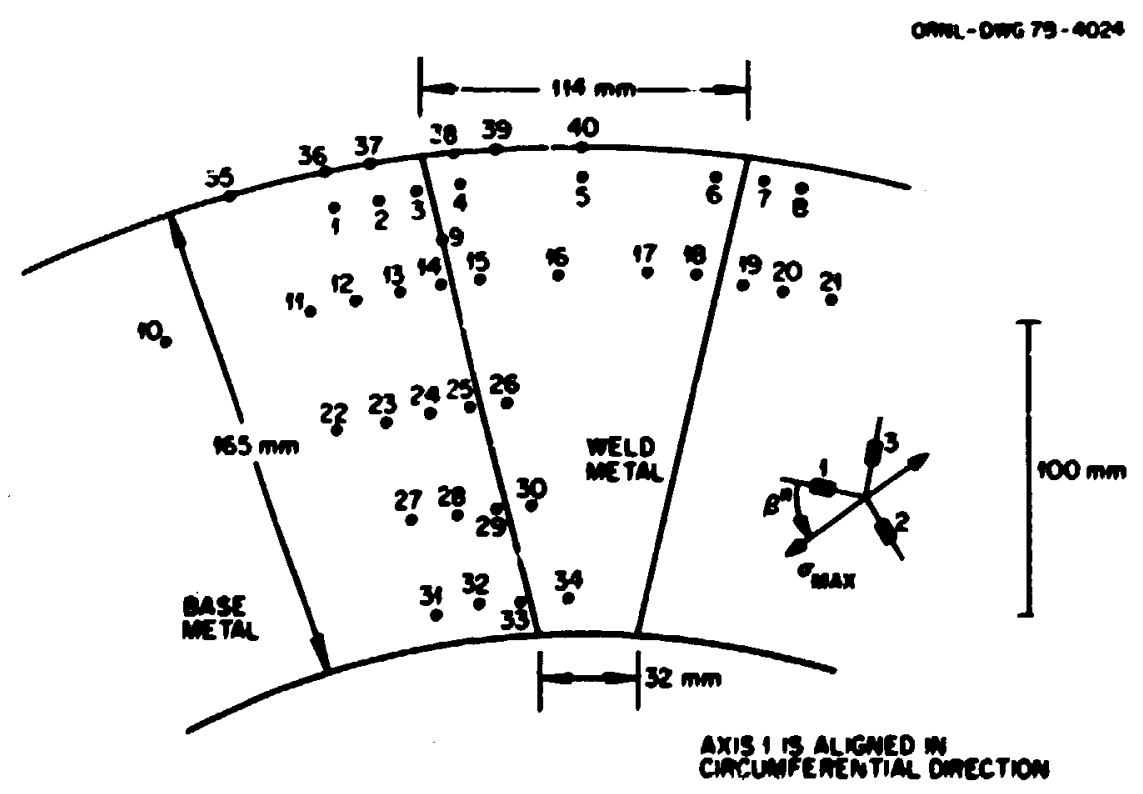

718. E.12. Hole-drilling eneurenent layout for measuranents on a circunferential plane of the V-7A ofulation repatr weld. WRDC veasureeent locations on piece $C$ of Fis. 5.1. See Table E.5 (100 $=3.94$ in.). 
Dink- - 0 to ro- 4025

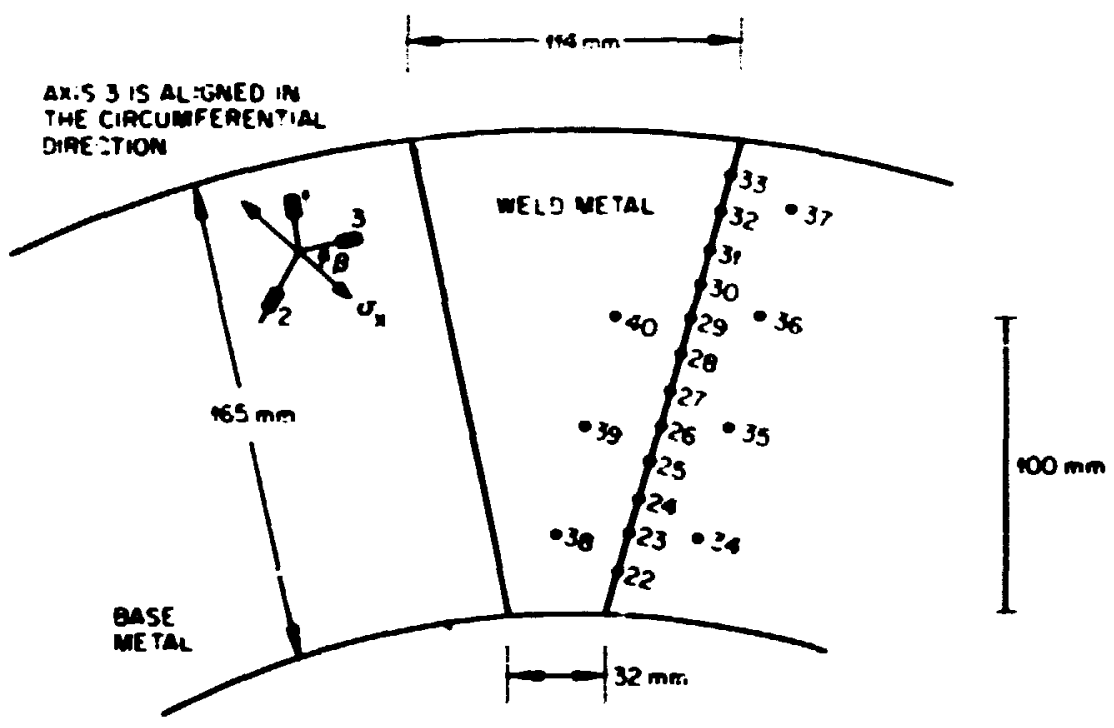

Fig. E.13. Hole-drilling measurement layout for measurements on a circunferential plane of the V-7A sinulation repair weld. ORL measureeent locations on piece C of Pig. 5.1. See Table E.6 (100 m = 3.94 in.).

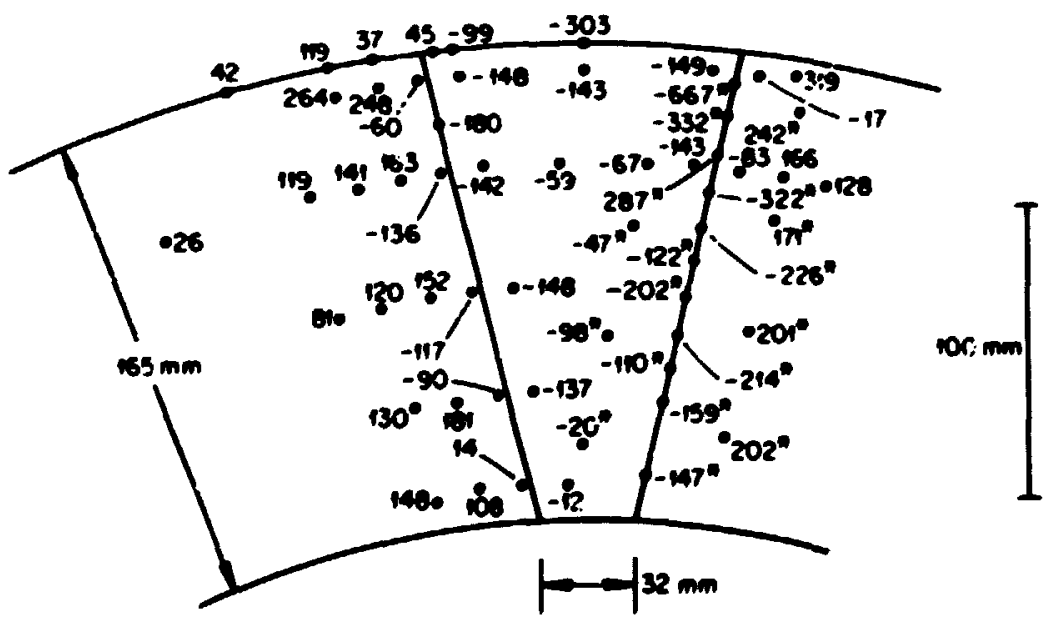

- mocates conk onta

othet DatA AnE Fnom wioc

F18. B.14. V-7A stulation repair wid circuferential residual stresses (MPa) determined wth the hole-drilling method, wo correction for sectionias ( $1 \mathrm{MPa}=145 \mathrm{pet} ; 100=3.94 \mathrm{in}$.). 


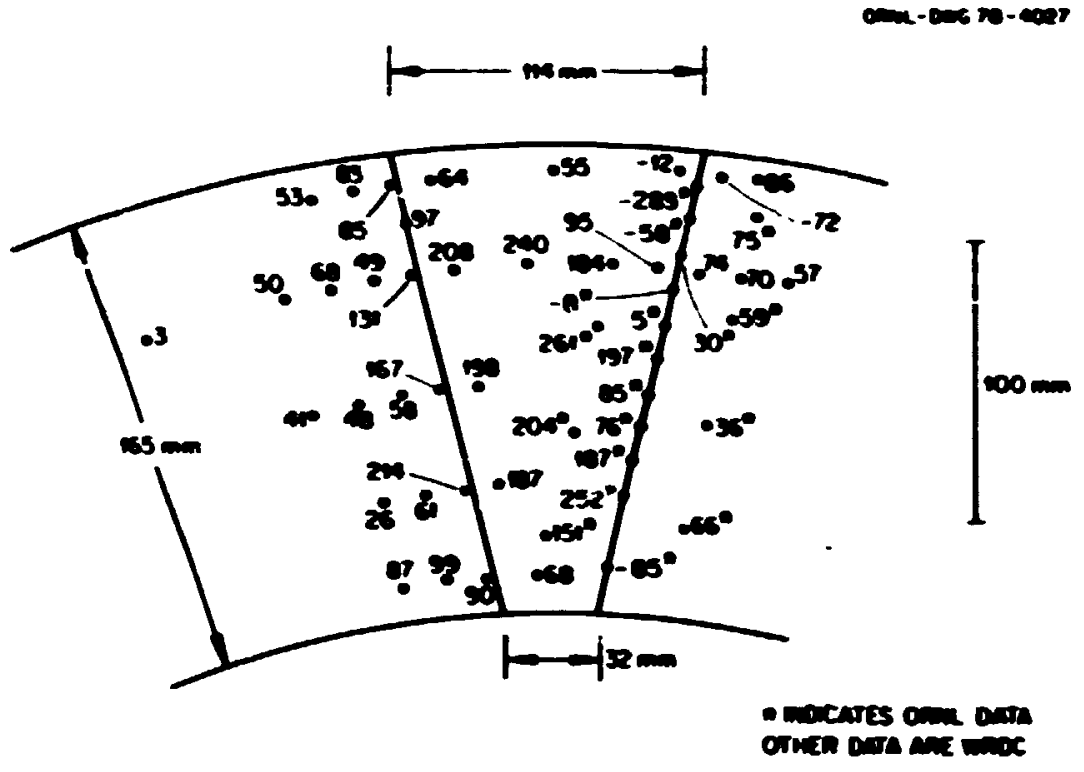

F18. E.15. V-7A sinulation repoir wid redial residual stresses (IPa) deternined with the bole-drilling method, wo correction for sectioniog (1 BPa - 145 pat; 100 = 3.94 in.).

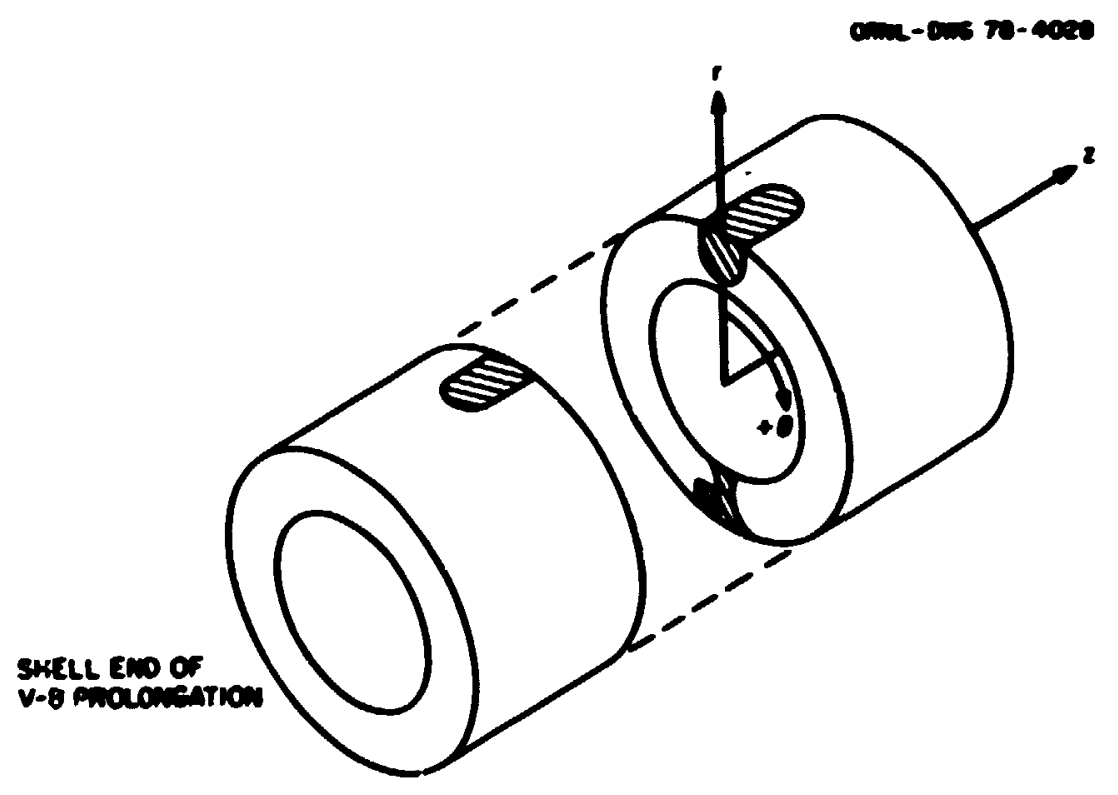

718. E.16. Coordinate goten used to define the hole-drilling residual streas mencurcane locations about the V-7B atmiation repair wid. The $\mathrm{r} z$ plane 10 a plane of s/metry for the V-7B simulation repait weld, and the ro plene dividee the V-8 prolongetion into two equal pieces. 


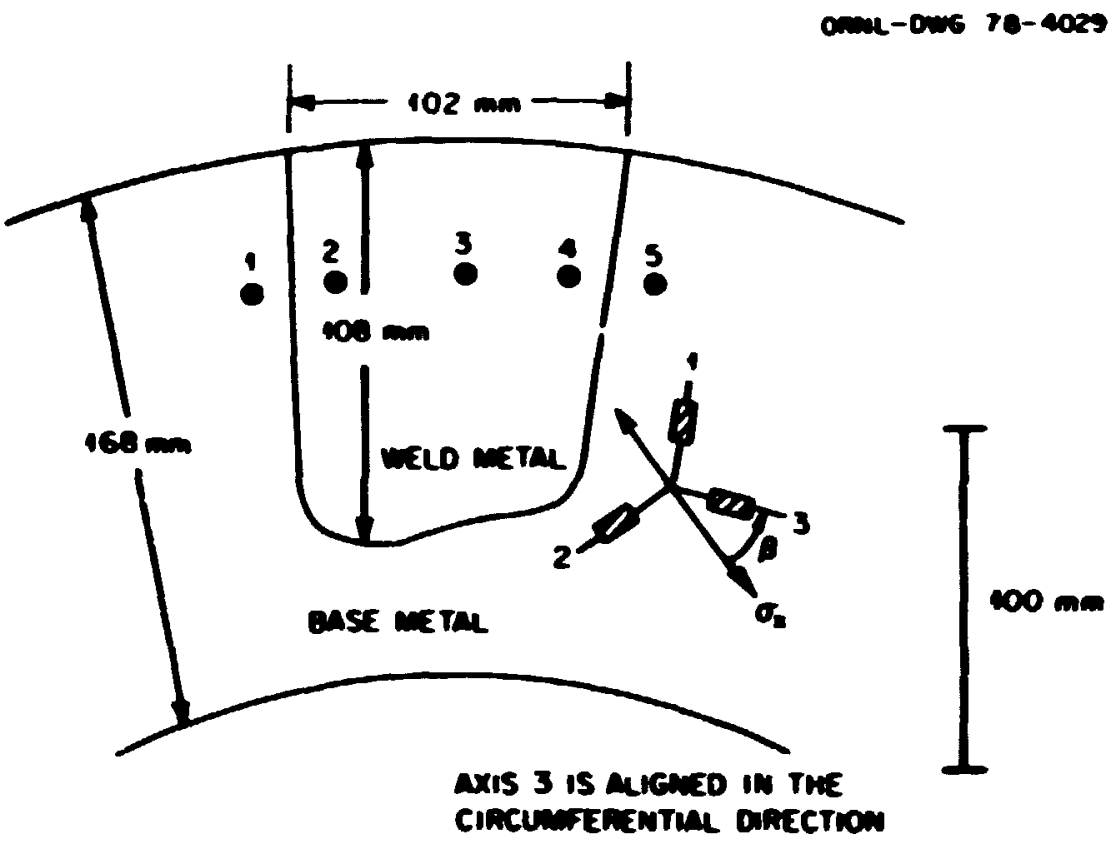

F18. E.17. Bole-drilling measurenent layout for meavurenents on a circunferential plawe of the V-7B simulation repair wid. See Table E.7 $(100 \mathrm{mos}=3.94 \mathrm{in.})$.

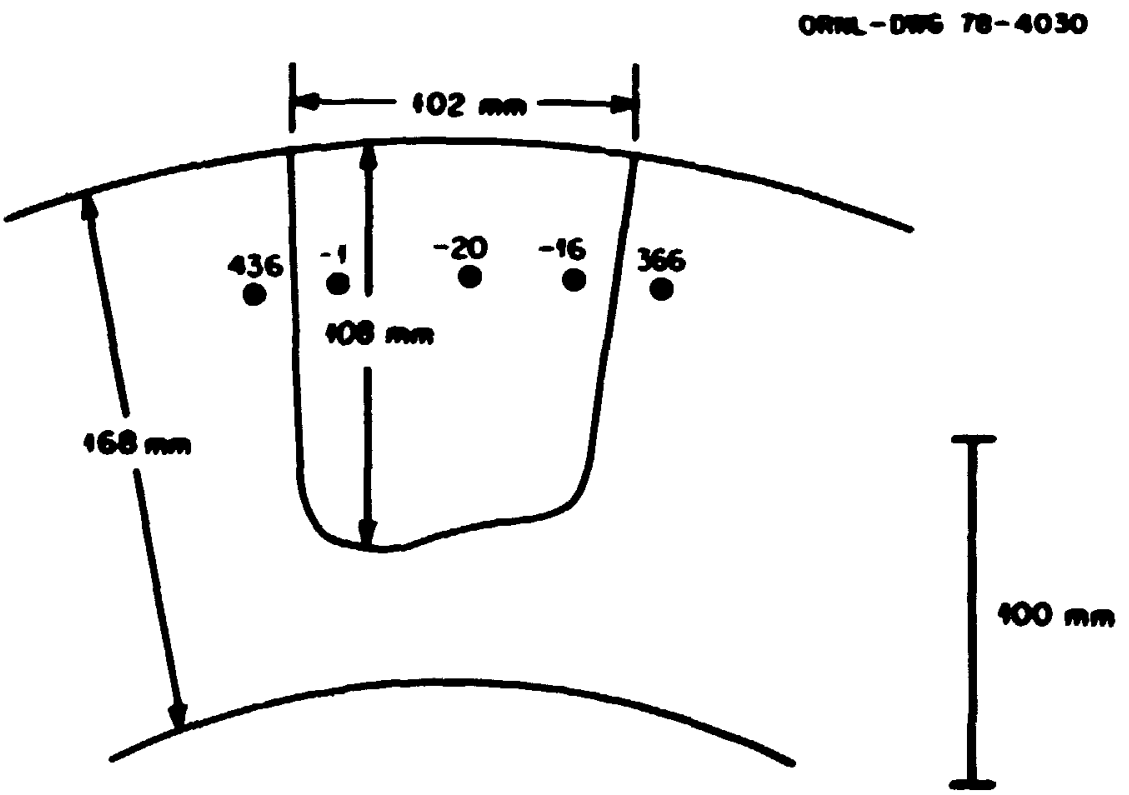

718. 2.18. Circunferential residual streses (MPa) in the V-7B simuletion repair weld, no correction for eaceloning. A full penetration is not shown becauce the saw cut bicecting the V-8 prolongetion cut the V-7B weld repair as it eransitioned from the inotde to outside contours (see

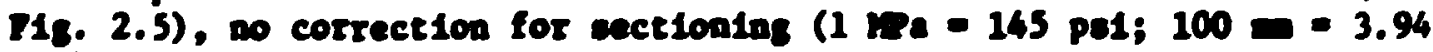
(n.). 
and-ous $70-\cos$

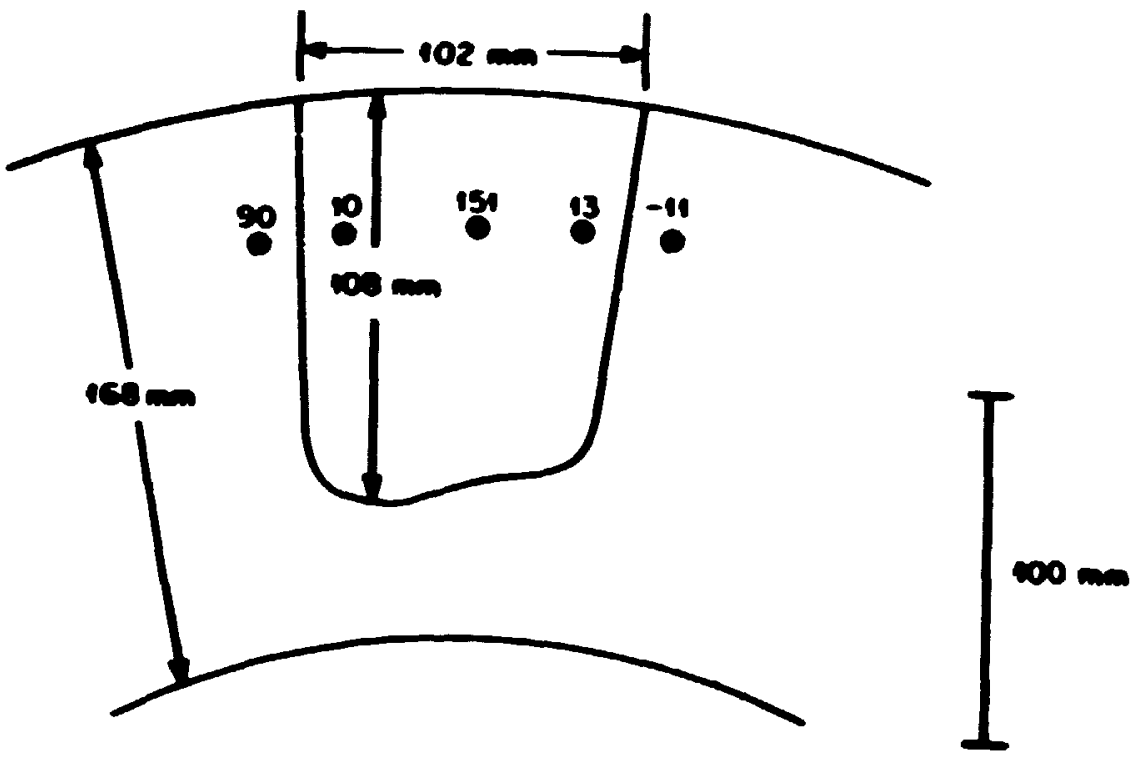

F18. E.19. Radial residual stresces (OPa) in the V-7B ot nulation repair weld, no correction for sectioning (1 Ma $=145 \mathrm{pel} ; 100 \mathrm{~m}=$ 3.94 in.). 


\section{Appendix F}

V-8 SEIES REPAI WELDS - HOLE-URILLING FIESURDIJTS

Appeadix F coateins the boledrilling date for the V-8 simulation repair weld. A diccueston relating to bole-drilling cype neasurenents Is contained in Chopter 4.

Fiture F.l sbovs the coordinate syste used to reference centerpoints of the bole-drilling type rosetces used for through-thichness neasurenents on the V-8 prolongation (Tables F.1 and F.2). Ench neasurenent locetion listed in the cables is Identified by a mober and is shown to ceale relative to the weld cavicy outlines in P1gs. P.2 and F.3. The strains linted

coning-ons re-cose

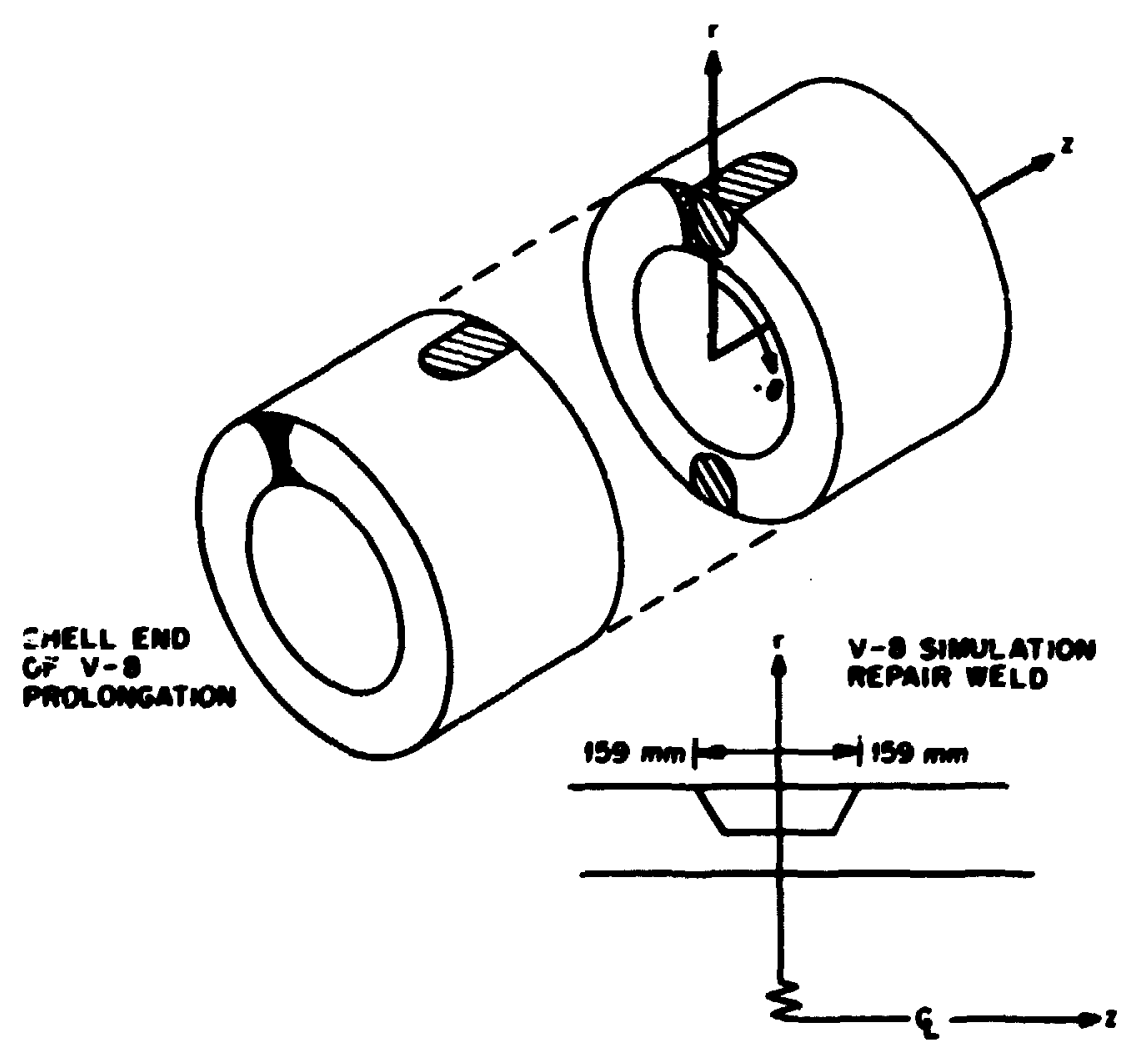

F18. P.1. Coordinate systcin used to define the hole-drilling residual etrese magurcinat locations about the V-8 stwulation repatr wid. The $r 8$ and $t 0$ planes are planes of oymetry for the V-8 stmulation repatr weld $(100=3.94 \mathrm{in.})$. 


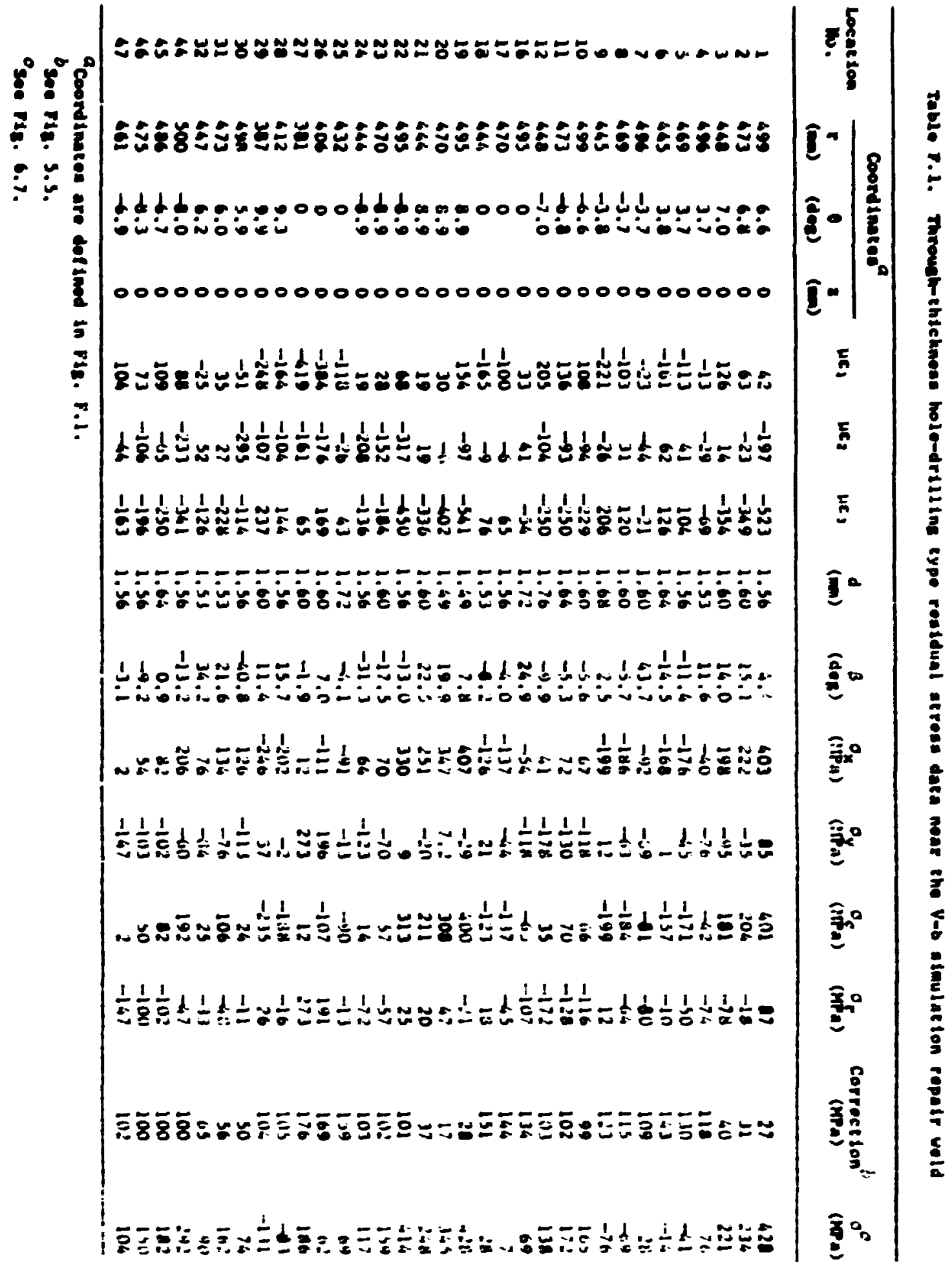




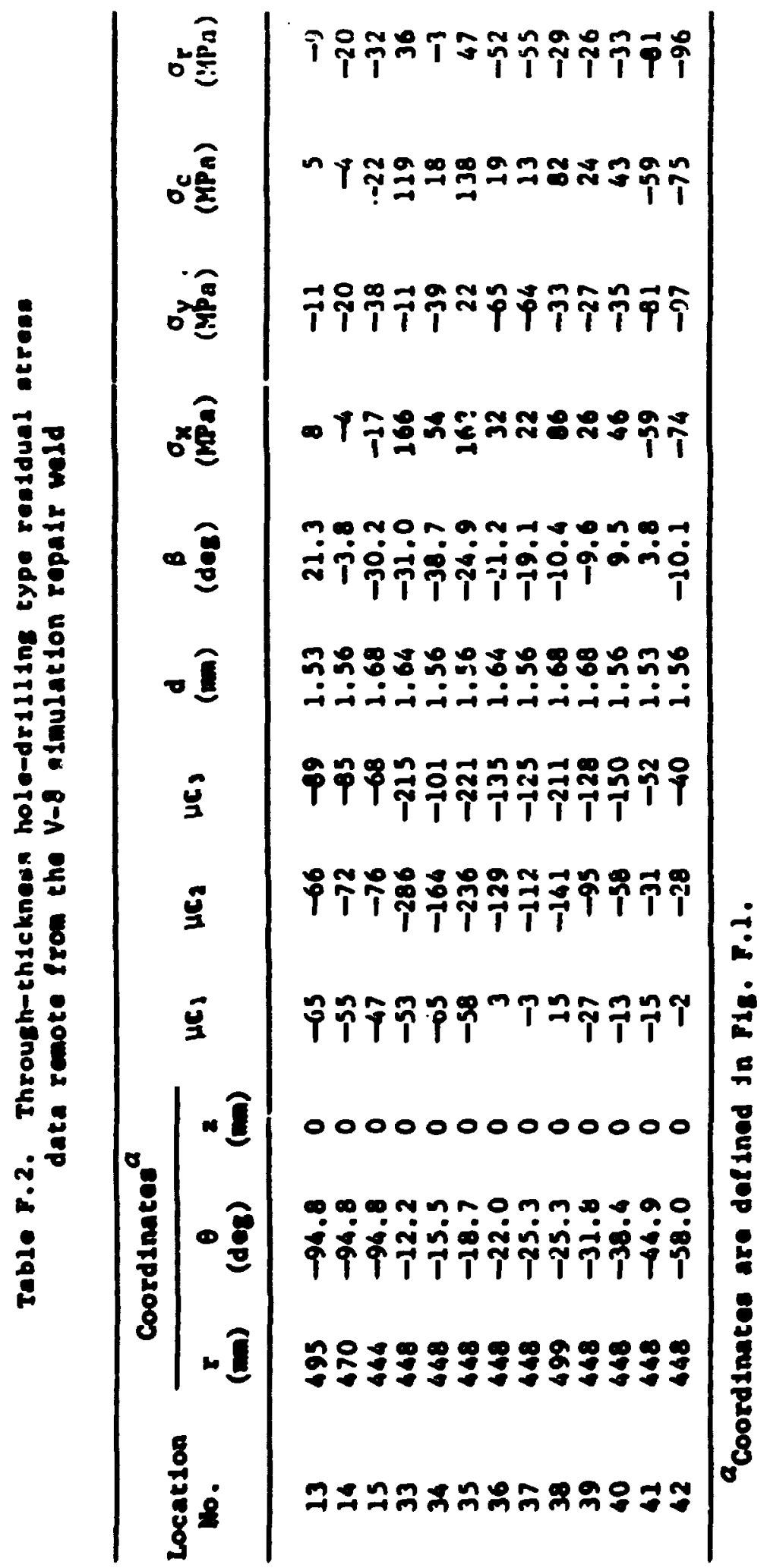




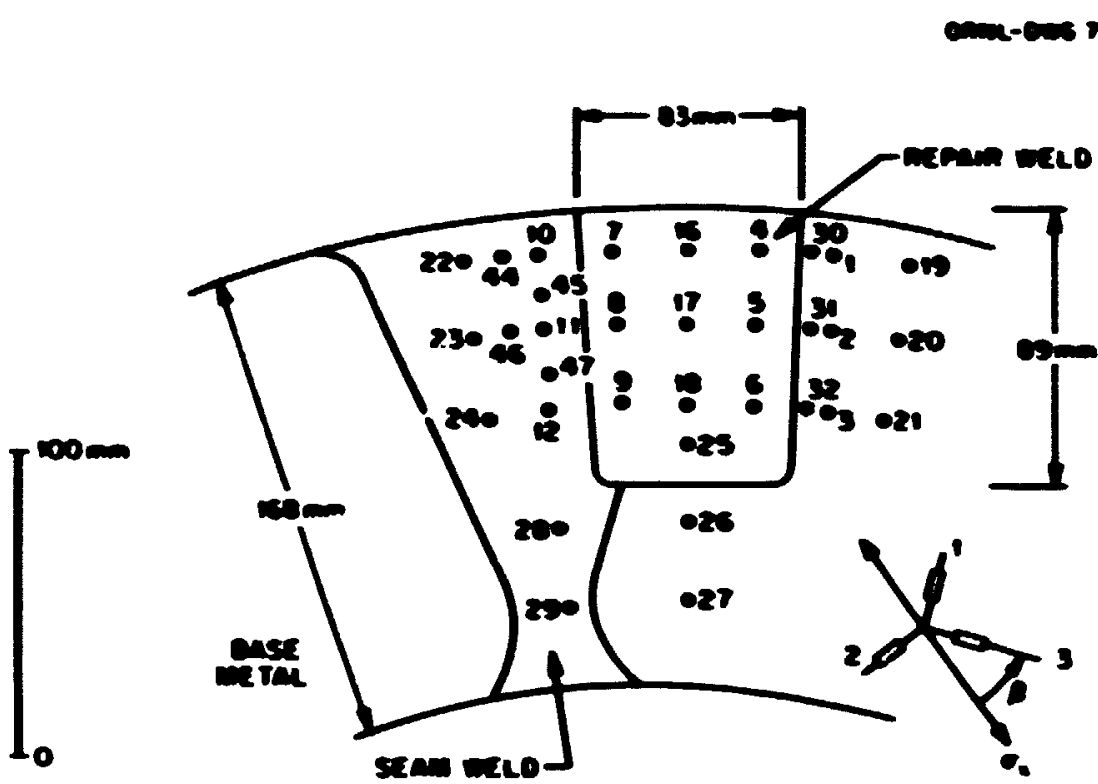

Ares 3 is arrego no

Twe cincumschiotial

omisetion

P16. F.2. Blo-drilling mesurenent lesout about the V-8 sibulation repatr wld. See Table F.1 (100 00.94 in.).

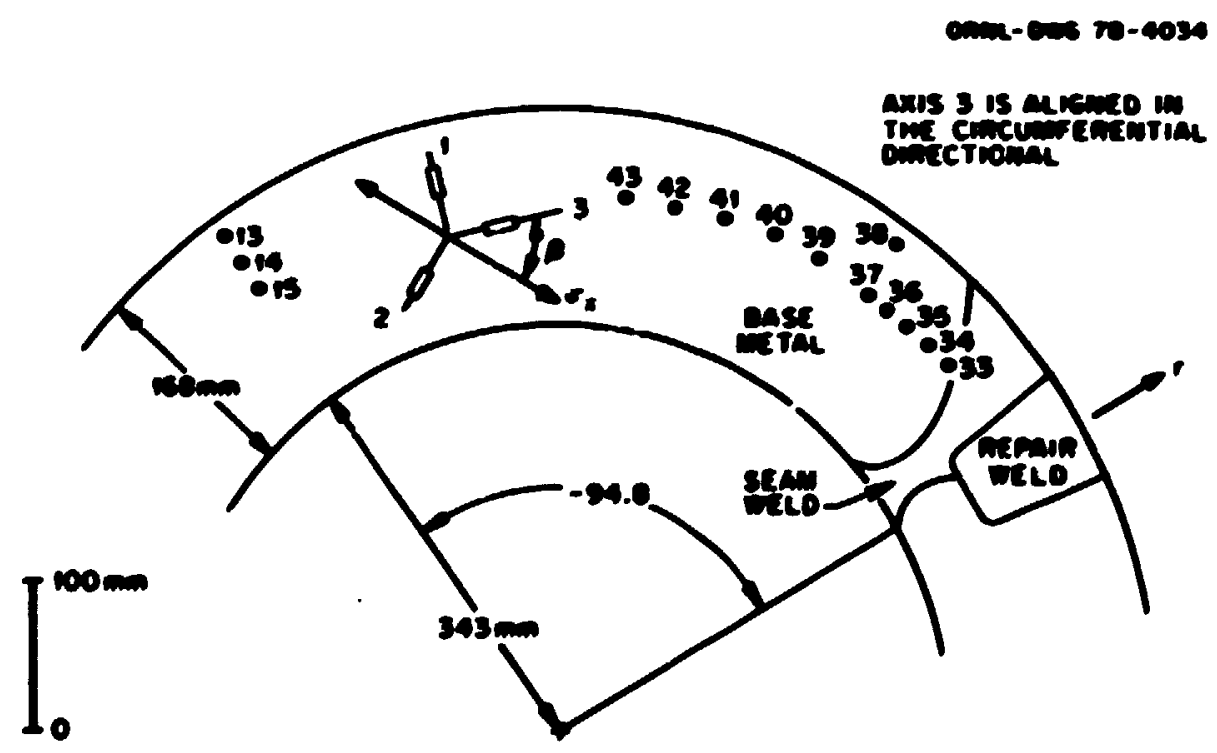

118. 7.3. Dolo-drilliog nanouranet loyout cbout the V-8 efmulation

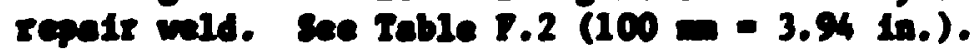


In the cables are the values that were ceesured when the drilled hole dopth

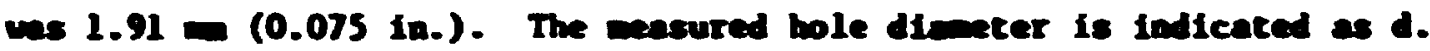

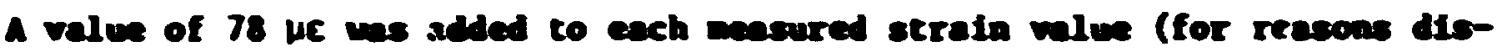
cused in Appendix B) to calculate the angle B and principal streseas $\sigma_{X}$ and $\sigma_{y}$ by the wethod described in Chaptex 4. The ancle $B$ is defined in Fis. 4.4. and the direction 3 shoug in that figure is always aligad in the efrenferentin direction. The streases $\sigma_{c}$ and $\sigma_{r}$ are the streas compantes reaolved in the circunferential and radial directions and are shom relative to the cold covity ad wen weld ontlines in Fige. F.4. F.5, and F.6. An extinate of a correction for eectioning is discuased in

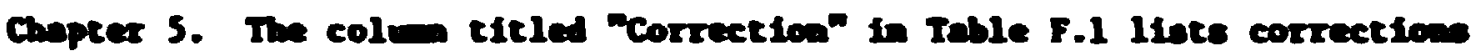
caken fron Fis. 5.5, which when addad to $\sigma_{c}$ give the eatincted cirenferential streas, $\sigma$, that existed in the proloneation prior to sectioning. These presectionad estinates of the circuferential streses are plotted In Fis. 6.7.

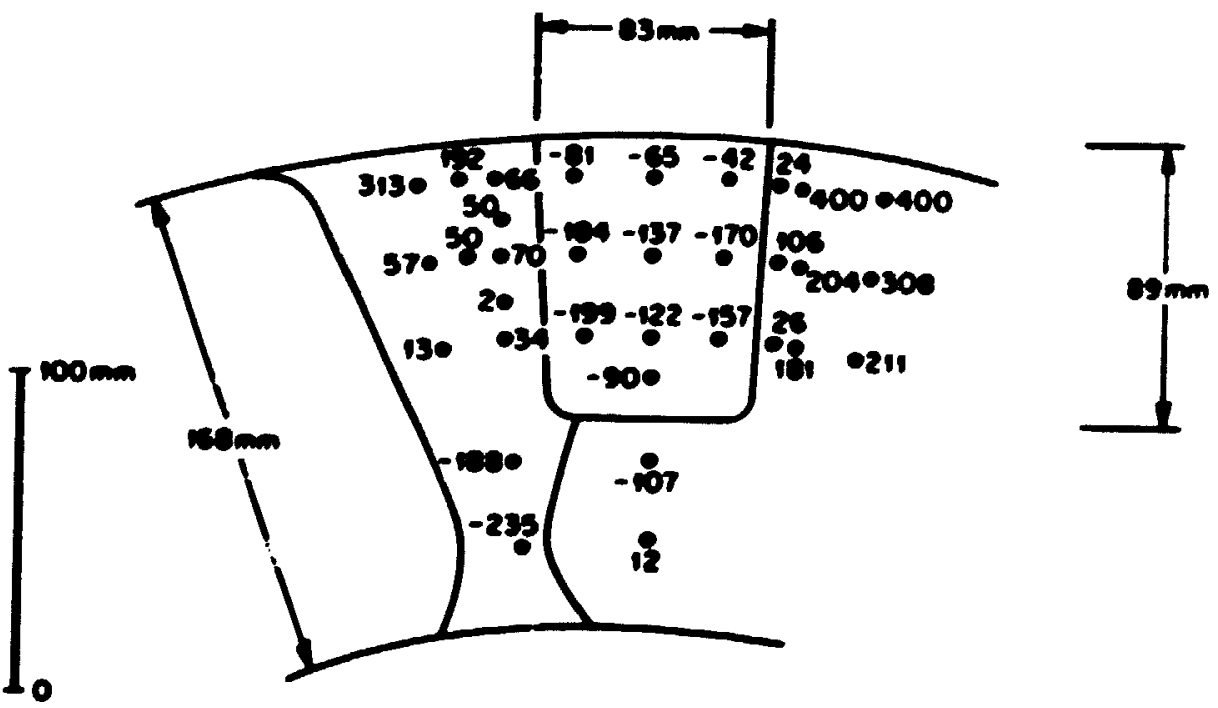

T18. P.4. V-8 ofulation ropatr wid circuferentinl residual etreses (I, deternined to the hole-drilling method, so correction for scetiontor (1 YPa - 145 pot; 100 ma 3.94 1n.). 


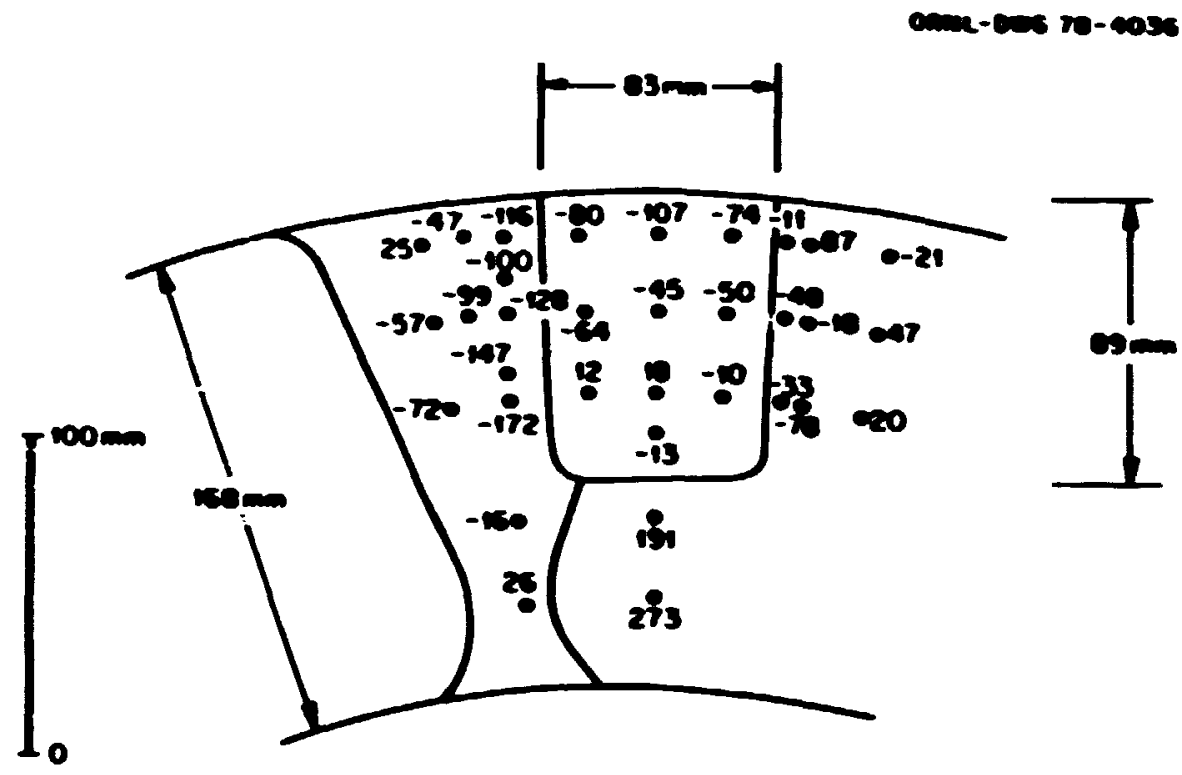

Fi8. F.S. V-8 sibulation repair weld redial residual stresses (Ma) deternined by the bole-drilling wethod in close proxinity to the repair weld, no correction for sectioning ( 1 ipa $=145$ pst; $100=3.96$ in., 100.039 (n.).

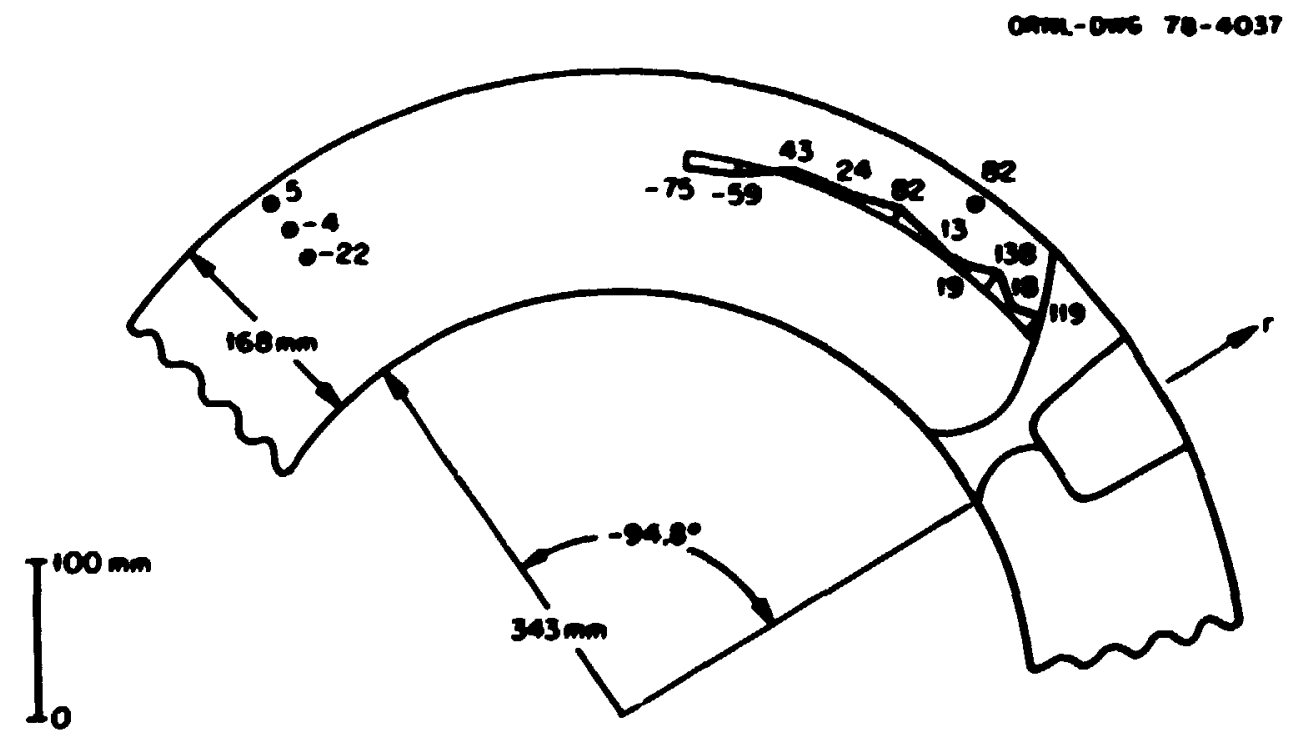

718. P.6. V-8 oimlation repair wid cireufercotial rest.dual etresees (IPa) deternifeed by the hole-drilling method rewote from the

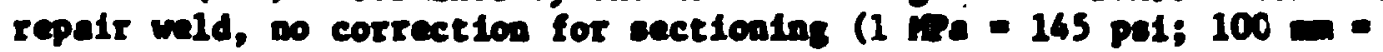
$3.94 \mathrm{in.}$ ). 
Appendix 6

DISCUSSIOA OF TIE WOLE-DRILIIE TYPE SURFACE RESIDUAL

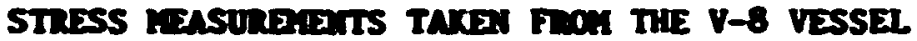

Appeadix C contalos a discusetion of 42 residual stress mensurements ade on or near the surface of the $V-8$ veseel using the bole-drilline ecthod. Twenty-four of thoce measurements were mode at surface locations that were in or near the V-8 half-bead repair weld. The other 18 measurenents were ede at sites that were located $180^{\circ}$ froe the repair weld. The purpoce of these latter 18 measurements was to allow on escesenent of skin effects that aight hove resulted from the final exchining to contour received by the V-8 vessel during its origipal fabrication and asechly.

The skin effect ascentment wo made by taking 3 sets of 6 measurements at differeat depthe relative to the exterior surface. The first set of 6 bole-drilling measuremests was ande on the as recelved surface of the vessel $180^{\circ}$ fron the repair veld. A gentle aill operation was used to rewove $3 \mathrm{wn}$ (0.115 in.) of surface naterial at the sace locations that had been used for the as received measurement. The second set of boledrilling wensurements wa then ande on the recesed surface that had reaulted from the gentle alll operation. After this second set of measurenents, 3 (0.115 in.) of material was again renoved and the final set of residual stress easurenents ws axde. The gentle willing und for this assescont Involved 42 pasees with a 63-mandia (2.5-in.) carbide-tipped end at11. First, 2 pasees of $0.254-6$ (0.01-in.) material removal were ande. This was followed by 6 passes of 0.127 (0.005 in.) and 24 passes of 0.0635 m (0.0025 in.) gespectively. The last 10 passes involved the renoval of $0.0254=(0.001 \mathrm{in}$.) of aterial on each pass. Speed selections for the dry allling operations were $1020 \mathrm{rpm}$ for the tool and $132 \mathrm{ca} / \mathrm{min}$ (52 In./nin) for the cable. The purpose of the gradual reavel of anterial we to efinfize residual stresese that would result from the alling process.

Table G.1 conteins a list of 6 residual stress mensurcinents (holedrilling type) ande on a stress-free bar [1.e., stress relleved at $746^{\circ} \mathrm{C}$ $\left(1375^{\circ} \mathrm{P}\right)$ for $72 \mathrm{hr}$ and furnace cooled for $24 \mathrm{hr}$ ] In a location that had recetved the ene gredual anteriel removal procese that we given to the 


\section{Table G.1. Hole-drilling cype realdual stress neasurenents on a streje free plate that had received the sane nilline procees used to gradually renove surface atcertal from the $U-8$ vessel}

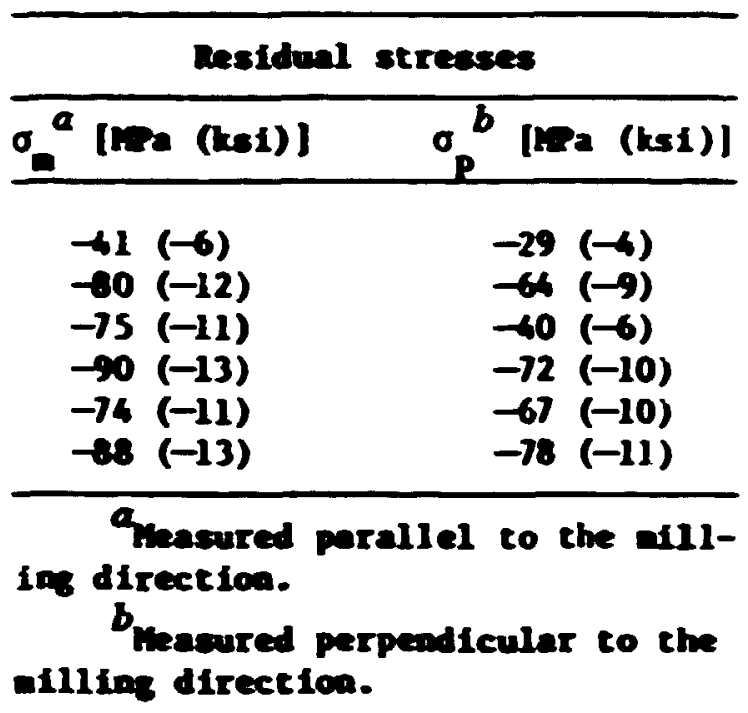

selected locetions on the $V-8$ vescel. Table $G .2$ contains a 11 st of 18 residual streas neavirenents ande $180^{\circ}$ from the $V-8$ repair weld. From the date in Table G.1, It would appear that the gredual alling process itself induced some compreseive residual stresses which were of the order of $75 \mathrm{MPa}$ (11 kaf). That level of stress is not significanty different from the meacurcante wade at depehs of $3 \mathrm{~m}(0.115 \mathrm{In}$.) and 6 (0.230 in.) froe the aurfece (Table G.2). These data thus confirs other weasuremeats which bove indicated that low residual stresses exist at locations reote frow the half-bead repatr mid. There is, houver, a large difference between the restdual atresces wesured on the as recelved $V-8$ veseal surface and those ande at shallow depths and on the stress free bar. These results argest that very large and vary shallow rompressive streases were put into the $V-B$ vessel when it received its final machining durlng ascenbly.

The study of the ekte effects described above was performed to evaluate the restdual stresses existing in the vesed at pointe removed from the repair wald and to interpret surface residual stress mesurciments ande 
Table C. 2. Loledrilling type residual seress ceasurencate ade on the $V-8$ vescel at varicos depthe relative to the veacel outside surface and at locations $180^{\circ}$

frow the half-bead repeir weld

\begin{tabular}{|c|c|}
\hline Clreufereatin serees $a^{a}$ & Axial stress \\
\hline$[\ln (\operatorname{les} 1)]$ & [ma $\left.{ }^{\sigma}(\operatorname{los})\right]$ \\
\hline
\end{tabular}

As recelned $u-b$ eurface

$\begin{array}{ll}-275 & (-40) \\ -206 & (-42) \\ -269 & (-39) \\ -261 & (-30) \\ -322 & (-47) \\ -279 & (-40)\end{array}$

$$
\begin{array}{ll}
-264 & (-33) \\
-265 & (-39) \\
-228 & (-33) \\
-250 & (-37) \\
-303 & (-44) \\
-277 & (-40)
\end{array}
$$

3 (0.115 in.) belos the V-8 surfece

$$
\begin{aligned}
& -83(-12) \\
& -85(-12) \\
& -4(-9) \\
& -6(-10) \\
& -69(-10) \\
& -91(-13)
\end{aligned}
$$

$$
\begin{aligned}
& -40(-6) \\
& -45(-7) \\
& -16(-2) \\
& -56(-8) \\
& -52(-8) \\
& -70(-10)
\end{aligned}
$$

6 (0.230 in.) below the V-8 arface

$$
\begin{aligned}
& -46(-7) \\
& -27(-6) \\
& -16(-2) \\
& -91(-13) \\
& -93(-13) \\
& -96(-16)
\end{aligned}
$$

9 (1)

21 (3)

$44(6)$

$-77(-11)$

$-73(-11)$

$-72(-10)$

athe geacle atliting we aligned with the vescel's circunferential direction.

In and near the repair weld. Plgure G.I shows a restdual strese mesure-

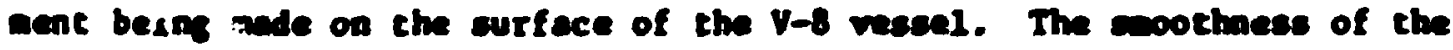
vesed's surface and the abrence of any ovidence of the fabrication welds ladicate the poscesecably wehtning thet wa done to rewove approxtantely 12 w $(0.5 \mathrm{ln}$.$) of matertal fros the ourface of the vessel. The surface$ 


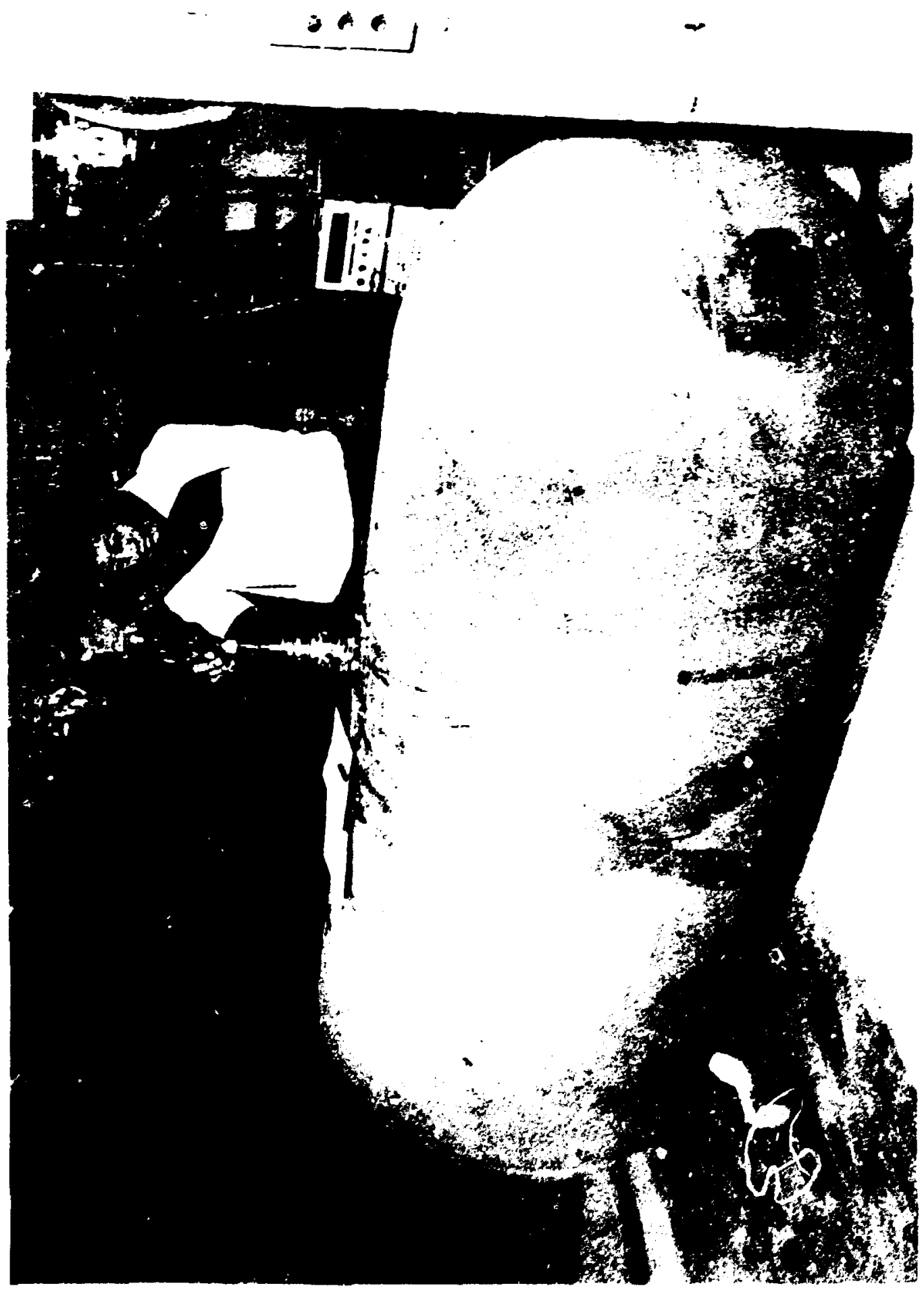




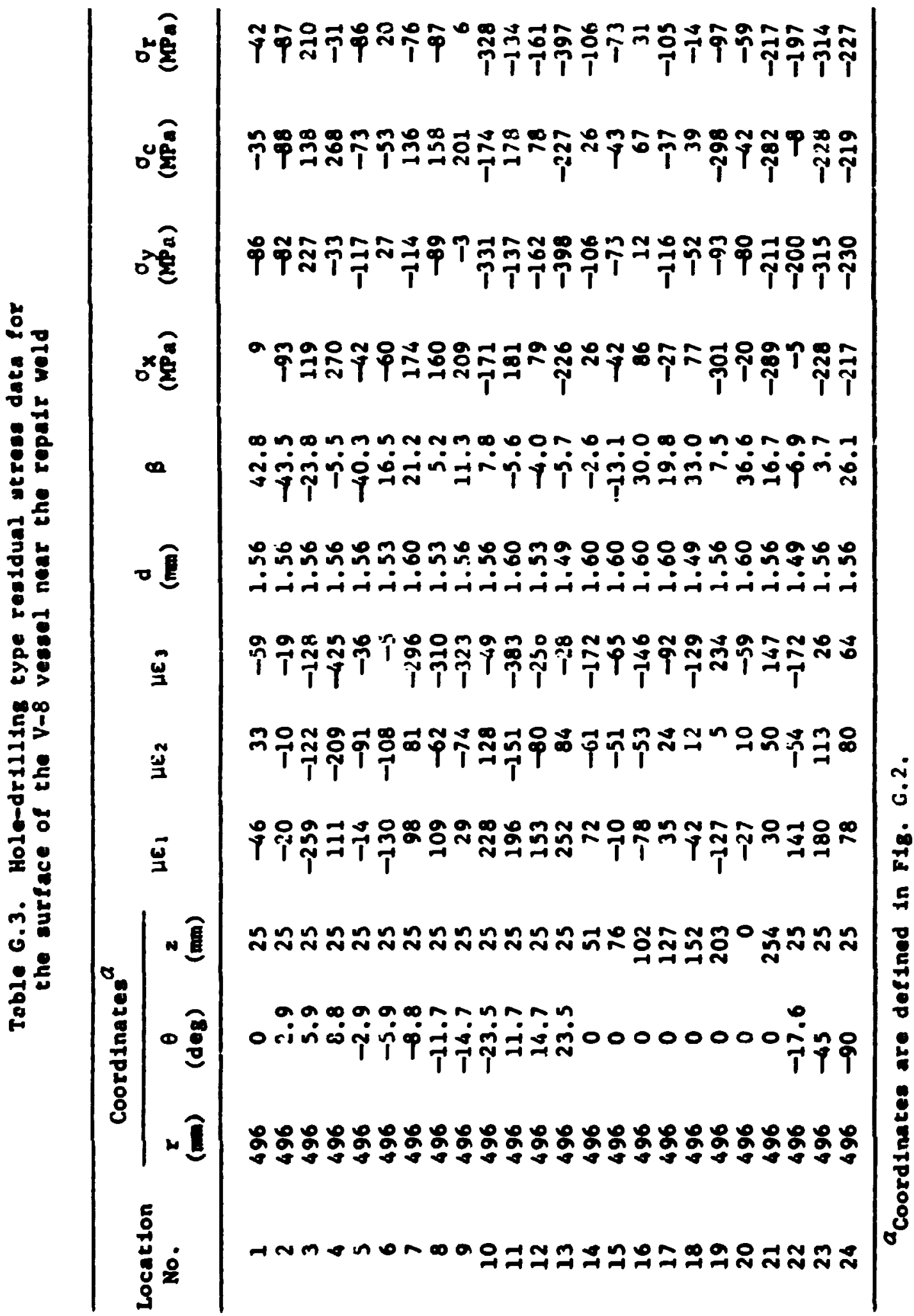


0man-0.6 7039
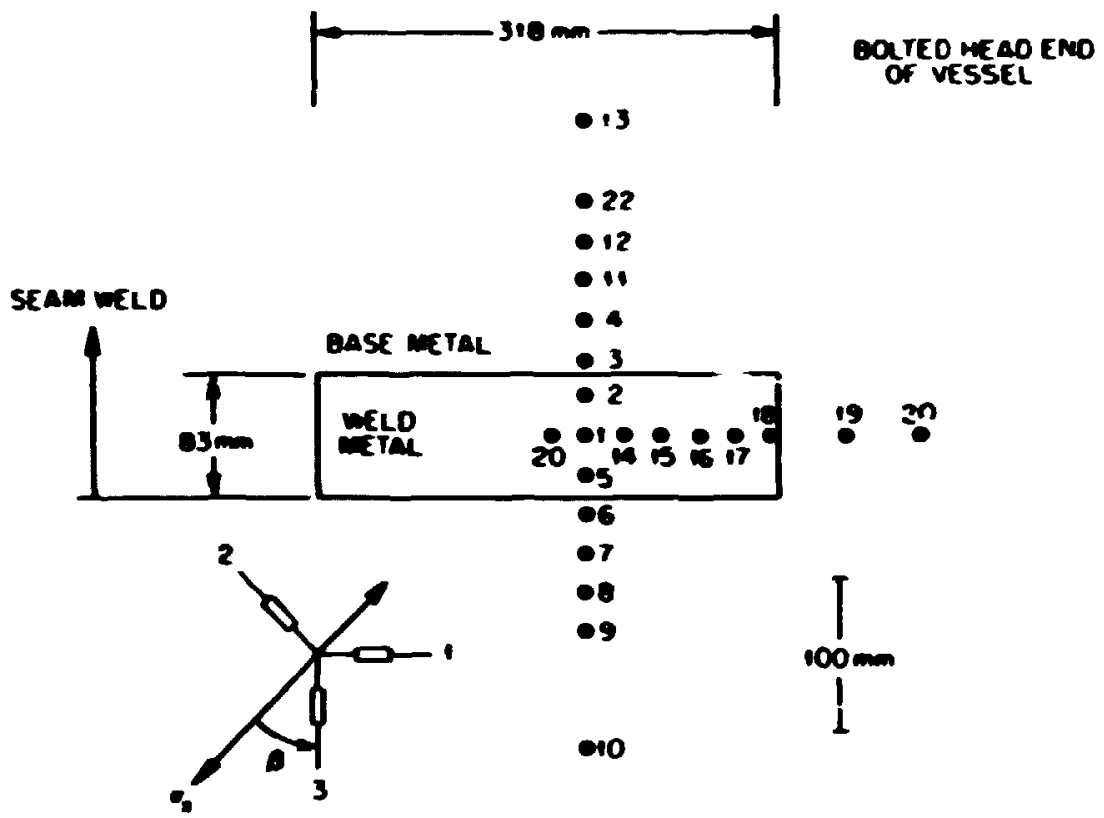

Fig-G.3. Hole-drilling measurement layout about the V-8 repair weld. See Table $6.3(100=3.94$ in. $)$.

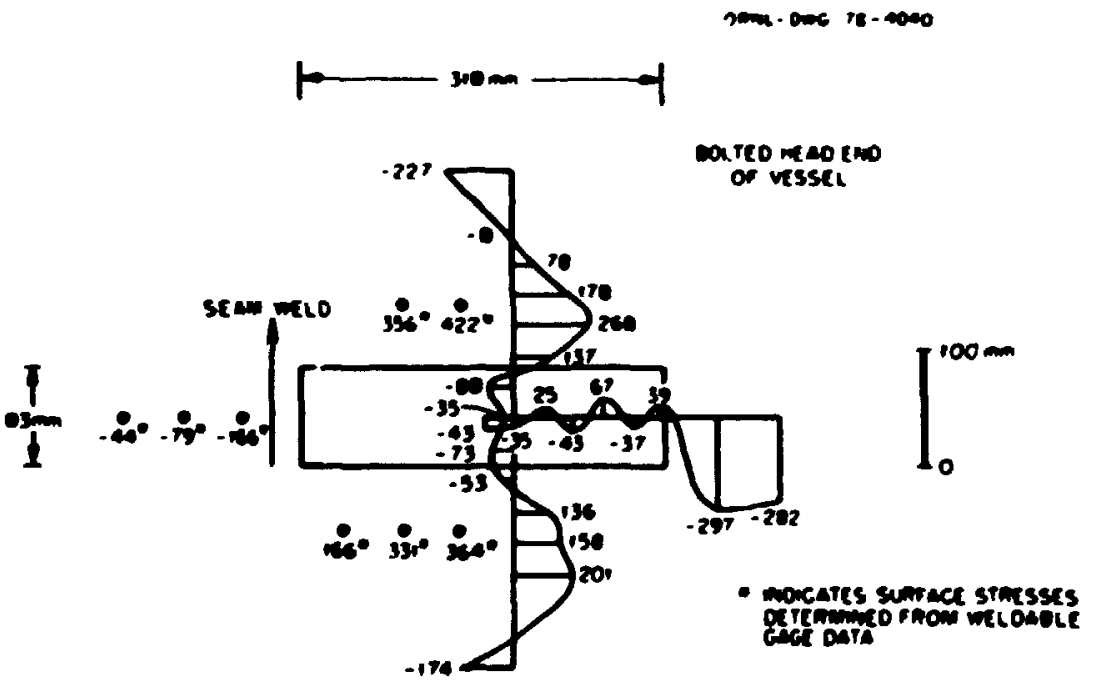

P18. C.4. Surface circuaferential residual atreases (HPa) about the $V-8$ repair weld ( $1 \mathrm{MPe}=145$ pe1; $100=3.94 \mathrm{In}$.). 


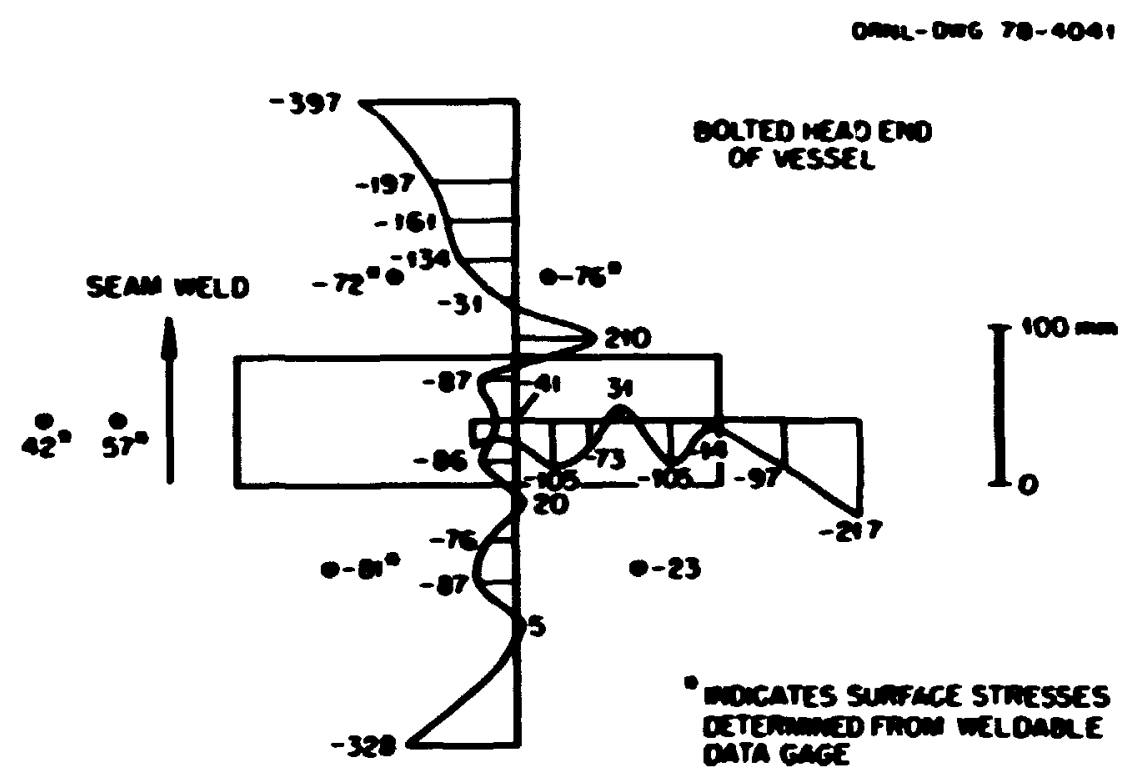

F18. C.5. Surface axial residual stresses (ara) about the v-8 repait weld ( $\mathrm{MPe}=145 \mathrm{pet} ; 100 \mathrm{~m}=3.94 \mathrm{~lm}$ ) .

could be expected when the compressive stress induced by the skin effect is considered. There is the additional complication however, that the surface near the repair weld was ground after the weld we comleted. Grioding which is not an intentional gentle griod can induce yet another oldn effect, which generally created a tenalle stress in material close to the surface. In the cace of the V-8 vessel the surface grind that was used to clean up the weld reston would tead to cancel the wachining skin effect discuesed previoualy in this section. The skin effects thus have the effect of obecurins the true curface residual stress, and prinary emphasis should be pleced on weldable cage data and through-thickness residual sereese meacurbente which me wade after the surface had been prepared according to a defined and controlled procedure. 